\title{
Flankerend geriatrisch beleid : het functioneren van geriatrische patienten tijdens ziekenhuisopname
}

Citation for published version (APA):

Fiolet, J. F. B. M. (1993). Flankerend geriatrisch beleid : het functioneren van geriatrische patienten tijdens ziekenhuisopname. [Doctoral Thesis, Maastricht University]. Datawyse / Universitaire Pers Maastricht. https://doi.org/10.26481/dis.19931014jf

Document status and date:

Published: 01/01/1993

DOI:

10.26481/dis.19931014jf

Document Version:

Publisher's PDF, also known as Version of record

\section{Please check the document version of this publication:}

- A submitted manuscript is the version of the article upon submission and before peer-review. There can be important differences between the submitted version and the official published version of record. People interested in the research are advised to contact the author for the final version of the publication, or visit the DOI to the publisher's website.

- The final author version and the galley proof are versions of the publication after peer review.

- The final published version features the final layout of the paper including the volume, issue and page numbers.

Link to publication

\footnotetext{
General rights rights.

- You may freely distribute the URL identifying the publication in the public portal. please follow below link for the End User Agreement:

www.umlib.nl/taverne-license

Take down policy

If you believe that this document breaches copyright please contact us at:

repository@maastrichtuniversity.nl

providing details and we will investigate your claim.
}

Copyright and moral rights for the publications made accessible in the public portal are retained by the authors and/or other copyright owners and it is a condition of accessing publications that users recognise and abide by the legal requirements associated with these

- Users may download and print one copy of any publication from the public portal for the purpose of private study or research.

- You may not further distribute the material or use it for any profit-making activity or commercial gain

If the publication is distributed under the terms of Article $25 \mathrm{fa}$ of the Dutch Copyright Act, indicated by the "Taverne" license above, 


\section{Flankerend Geriatrisch Beleid}

Het functioneren van geriatrische patiënten tijdens ziekenhuisopname 


\section{CIP-GEGEVENS KONINKLIJKE BIBLIOTHEEK, DEN HAAG}

Fiolet, Johannes Franciscus Bernardus Maria

Flankerend geriatrisch beleid : het functioneren van

geriatrische patiënten tijdens ziekenhuisopname /

Johannes Franciscus Bernardus Maria Fiolet. - Maastricht

: Universitaire Pers Maastricht.

Proefschrift Maastricht. - Met lit. opg. - Met

samenvatting in het Engels.

ISBN 90-5278-102-8

Trefw.: geriatrische patiënten ; ziekenhuizen.

\section{이.F.B.M Fiolet, Maastricht 1993}

Boekverzorging: Datawyse I Universitaire Pers Maastricht Omslagfoto: de "oude" Bruggeman 


\section{Flankerend Geriatrisch Beleid}

\section{Het functioneren van geriatrische patiënten tijdens ziekenhuisopname}

\section{PROEFSCHRIFT}

ter verkrijging van de graad van doctor aan de Rijksuniversiteit Limburg te Maastricht, op gezag van de Rector Magnificus, Prof. dr. H. Philipsen, volgens het besluit van het College van Dekanen, in het openbaar te verdedigen op donderdag 14 oktober 1993 om 13.00 uur

$$
\text { door }
$$

Johannes Franciscus Bernardus Maria Fiolet geboren te Rotterdam in 1953

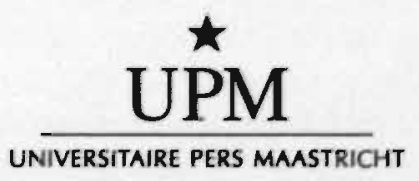




\section{Promotores:}

Prof. di. J.A. Flendrig

Prof. dr. H. Philipsen

Beoordelingscommissie:

Prof. dr. J. Jolles (voorzitter)

Dr. W.H.L. Hoefnagels (Katholieke Universiteit Nijmegen)

Prof. dr. C.F. Hollander (Riom, France)

Prof. dr. J.M.J.P. van der Linden

Prof. dr. J. Troost 


\section{INHOUDSOPGAVE}

Inleiding 7

Hoofdstuk 1 Geriatrie en geriatrische voorzieningen II

Hoofdstuk 2 Flankerend Geriatrisch Beleid 29

Hoofdstuk 3 Het onderzoek 39

Hoofdstuk 4 Het verschil tussen de onderzochte geriatrische patiënten en "gewone patiënten" opgenomen in het ziekenhuis 57

Hoofdstuk 5 Het geriatrische complex 73

Hoofdstuk 6 De situatie bij ontslag: ADL-funktioneren, mobiliteit en urine-incontinentieproblematiek $\quad 91$

Hoofdstuk 7 De overleden patiënt 117

Hoofdstuk 8 De bruikbaarheid van de BOP-schaal en de GIP-schaal voor klinisch geriatrische patiënten $\quad 127$

Hoofdstuk 9 Samenvatting en konklusies 153

Literatuur $\quad 161$

Summary $\quad 173$

Dankwoord $\quad 177$

Curriculum vitae $\quad 179$ 


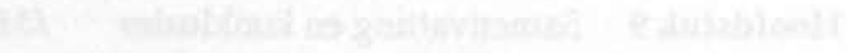

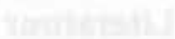

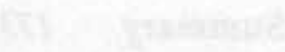

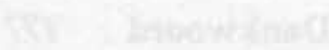

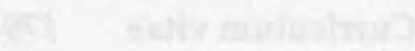




\section{Inleiding}

In de diskussie over geriatrische patiëntenzorg keren een aantal onderwerpen steeds terug.

De specifieke kenmerken van de geriatrische patiënt, de kwaliteit waaraan de zorg moet voldoen en de mate waarin deze zorg efficiënt kan zijn in termen. van overleving en beter funktioneren zijn dergelijke onderwerpen.

Bij de politieke besluitvorming en het strategisch beleid van gezondheidszorgvoorzieningen inzake de vergrijzing zijn het met name de epidemiologische gegevens van de totale populatie ouderen die een doorslaggevende rol lijken te spelen. Van ouderen wordt in de landelijke (nederlandse) politiek momenteel gesproken, wanneer het gaat om personen vanaf 55 jaar. De omvang van deze populatie en de getalsmatige ontwikkelingen in de komende decennia zijn indrukwekkend. Terecht plaatsen vele werkers in de gezondheidszorg echter vraagtekens bij de gehanteerde leeftijdsgrens. Weliswaar is deze leeftijdsgrens sociodemografisch te verdedigen - arbeidssituatie, sociale positie, woonbehoeften, e.d. zijn voor de groep boven de 55 jaar substantieel anders dan voor de groep onder de 55 jaar - maar medisch gezien is er weinig of geen reden, wanneer het gaat om veroudering c.q. vergrijzing bij deze leeftijd de grens te trekken. Ook de 55-plussers zelf lijken niet erg gecharmeerd van de gedachte dat zij met het passeren van genoemde leeftijdsgrens beschouwd zouden moeten worden als ouderen. De oude situatie waarin mensen ouder dan 65 jaar - d.w.z. zij die de pensioengerechtigde leeftijd officieel zijn gepasseerd - beschouwd worden als ouderen ofwel bejaarden, biedt evenmin een goed hanteerbare situatie. Ook boven de 65 -jarige leeftijd treedt geen direkte omslag op in medische hulpbehoefte of morbiditeitspatroon. Wel is het zo dat uit morbiditeitsgegevens blijkt dat vanaf de zesde levensdecade voor een groot aantal aandoeningen, handicaps en beperkingen geldt dat een duidelijke stijging valt waar te nemen. Deze stijging is voor de groep als geheel niet abrupt, maar veelal wel in meer of mindere mate exponentieel. Hoewel specifieke ouderdomsziekten feitelijk niet bestaan leidt dit ertoe dat voor een veelheid van aandoeningen, verdeeld over vrijwel alle specialismen, geldt dat het vóórkomen toeneemt met de leeftijd. Het zal daarbij niet verbazingwekkend zijn dat hieronder zich veel zgn. chronische aandoeningen bevinden en dat de kans op het gezamenlijk voorkomen van meerdere aandoeningen - zeker bij de hoogbejaarden - aanzienlijk is.

Voor zover aandoeningen zich wat betreft presentatie, beloop en/of behandeling op oudere leeftijd anders manifesteren dan op jeugdiger leeftijd is dit een argument voor meer specifieke kennisontwikkeling in deze richting. Toch 
heeft de klinische geriatrie als toegepaste medische wetenschap veel meer moeite geaccepteerd te worden dan het meer basale gerontologisch onderzoek. Het is in eerste instantie voor de hand liggend de geriatrie te zien als de antipode van de kinder- en jeugdgezondheidszorg: aan het einde van het leven heeft de mens konform de situatie in het begin behoefte aan een apart type zorg. Voor de kinder- en jeugdgezondheidszorg is deze situatie zeker in de eerste levensdecade goed verdedigbaar. Alle mensjes c.q. patiëntjes verschillen duidelijk van de rest van de bevolking: zowel in lichamelijk als in geestelijk opzicht zijn zij nog niet volwassen in de meest letterlijke zin van het woord. Rekening moet worden gehouden met de nog in gang zijnde lichamelijke en psychische ontwikkelingsprocessen. Daarnaast zal deze populatie in maat en getal verschillen van de overige bevolking wat eisen stelt aan diagnostiek, behandeling en voorzieningen. Geleidelijk aan - met het vorderen der jaren - wordt het verschil kleiner en uiteindelijk zal, op een nauwelijks te definiëren moment en wisselend van persoon tot persoon en van aandoening tot aandoening, de grens worden overschreden en de volwassenengezondheidszorg in de plaats komen van de kindergeneeskunde. Voor de oudere patiënt ligt, zoals gezegd deze situatie anders. De geleidelijke overgang ligt niet aan het eind, maar aan het begin van de levensfase, het evidente onderscheid - als het al aanwezig is - niet aan het begin maar aan het einde. Zo duidelijk als er aan het begin van het leven sprake is van groei en differentiatie, zo onduidelijk zijn veelal de sporen van toenemend funktieverlies. Fysiologisch gezien is dit heel wel verklaarbaar. Alhoewel voor vrijwel alle organen en orgaansystemen geldt dat er vanaf het bereiken van de volwassen leeftijd een geleidelijke teruggang te bewijzen is in termen van maximale capaciteit heeft dit niet zonder meer tot gevolg - onder normale omstandigheden - dat het funktioneren van de mens als geheel hierdoor ook in belangrijke mate verandert. Het is te danken aan de grote reservecapaciteit die opgebouwd wordt in de eerste dertig levensjaren dat het proces van geleidelijke achteruitgang met toenemende adaptatieproblematiek vaak pas bij het bereiken van de zevende of achtste levensdecade, en zelfs dan soms alleen nog onder stressvolle omstandigheden wordt opgemerkt. De fenomenen die dan optreden zijn in wezen niet verschillend van de uitvalsverschijnselen die kunnen optreden wanneer door gelokaliseerde afwijkingen c.q. ziekte op jeugdiger leeftijd orgaanfalen optreedt. Echter, het verschil zit daarin dat "de aandoening" niet langer gelokaliseerd is. Veroudering als zodanig is te beschouwen als een systeemziekte die vroeg of laat eindigt in multi-organ-failure: verscheidene zo niet alle orgaansystemen zijn hierbij betrokken en in geval van onbalans zal door het ontbreken van voldoende kompensatiemechanismen (= het verlies aan orgaanreserve) sneller een situatie bereikt worden waarbij het voortbestaan direkt wordt bedreigd. Ook deze toename in complexiciteit en/of comorbiditeit hoeft echter geen direkt argument te zijn voor specifieke gezondheidszorg voor ouderen. Het vraagt wel om meer kennis en kunde en brengt met zich mee dat de grenzen van een willekeurig specialisme, zowel 
als de grenzen van de generalist eerder worden overschreden. Multidiciplinaire samenwerking wordt meer en meer vereist, evenals een waakzaam oog voor de toenemende kans op komplikaties die om eerder genoemde redenen bij jeugdiger personen zelden of nooit optreden.

Tot dusver is veroudering en de problematiek die dit met zich meebrengt beschreven als een gegeven dat hanteerbaar is/zou moeten zijn voor de reguliere gezondheidszorg. Ook in pragmatische termen zal dit zo moeten zijn, juist met het oog op de grote aantallen ouderen nu en meer nog in de toekomst waarover wordt gesproken. De zorg voor deze populatie vraagt wel degelijk om aanpassingen in organisatie en handelswijze, maar doet geen beroep op een type medisch handelen wat niet voorhanden is.

Er doen zich echter situaties voor waarbij wel behoefte is aan een anderssoortig medisch handelen, $\mathrm{nl}$. in het geval van zgn. geriatrische patiënten. $\mathrm{Na}-$ drukkelijk wordt gesteld dat dit niet alle 55-plussers, 65-plussers, hoogbejaarden of welke leeftijdskategorie dan ook betreft. Het gaat hierbij om een relatief kleine subpopulatie (naar schatting 5\% van alle 65 -plussers) waarbij de verschijningsvorm van het verouderingsproces zodanig is dat meer gerichte deskundigheid gerechtvaardigd (b)lijkt. Wat zijn nu de specifieke kenmerken van de groep geriatrische patiënten? Ongelukkigerwijs is hierop geen eenduidig antwoord mogelijk. In de literatuur zijn vele min of meer bruikbare definities te vinden. Toch hebben al deze definities met elkaar gemeen dat geen absolute waarden of criteria worden aangegeven waardoor de gehele groep met voldoende specificiteit kan worden onderscheiden. In de medisch georiënteerde definities zijn wederkerende onderdelen multiple pathologie, somatische zowel als psychische en/of sociale problemen, een wankel evenwicht, mobiliteitsstoornissen, kommunikatiestoornissen, chronische hulpbehoevendheid en een veranderde cure/care verhouding. Dat de populatie geriatrische patiënten niet scherper te definiëren valt is op zich ook weer niet erg uitzonderlijk: betreffend probleem doet zich ook voor bij andere specialismen. Zo is ook de specifiek interne patiënt niet goed te definiëren en geldt voor vrijwel alle zgn. orgaanspecialismen dat zij in meer of mindere mate afbakeningsproblemen kennen t.o.v. aanpalende specialismen. Belangrijker wellicht dan een allesomvattende en dus nietszeggende definitie van "de geriatrische patiënt" is een inventarisatie van de belangrijkste punten waarop de geriatrische patiënt verschilt van "de gewone oudere patiënt" en een beschrijving van de medische en psychosociale problematiek die behoort tot de "harde kern" van datgene waarmee het specialisme geriatrie zich bezighoudt. Een dergelijke beschrijving is noodzakelijk zowel voor een verantwoorde gezondheidszorg in medisch-technisch opzicht, als voor het bepalen van de kwaliteiten waaraan de organisatie moet voldoen waarbinnen deze zorg gegeven wordt. Deels hiervan afgeleid, deels hiertoe leidend, zullen deze gegevens ook inhoud en struktuur moeten geven aan de kwaliteit van de opleiding tot geriatrisch specialist en de basis vormen voor datgene wat de 
basisarts en anderen werkzaam in de gezondheidszorg moeten weten van geriatrische patiënten.

De ontwikkeling van de klinische geriatrie in Nederland heeft zich lange tijd gekenmerkt door een strijd om legitimering van het bestaan van dit specialisme. Hierbij is veelvuldig - en uiteindelijk met succes - gepleit voor een volwaardige positie binnen de (klinische) gezondheidszorg, waarbij de eigen afdelingsstruktuur en de multidisciplinaire behandelmethodiek belangrijke voorwaardenscheppende doelstellingen vormden. Het al dan niet in geriatrische handen komen van een patiënt lijkt tot op de dag van vandaag echter meer beschikt te worden door lokale omstandigheden dan door een inhoudelijke afweging van de problematiek. Hiermee wordt niet bedoeld dat dergelijke inhoudelijke diskussies niet gevoerd worden of meespelen in de besluitvorming, maar dat getalsmatig ook daar waar voldoende geriatrische deskundigheid beschikbaar is nog steeds grote aantallen geriatrische patiënten niet of laat worden behandeld door geriatrische specialisten.

De doelstelling van het hier beschreven onderzoek is om een bijdrage te leveren aan de definiëring van het werkgebied van de klinische geriatrie. Hiertoe zijn een aantal aspekten onderscheiden, te weten

- het onderscheid tussen "gewone ouderen" en geriatrische patiënten

- medische en funktioneringskenmerken zoals die worden aangetroffen bij de presentatie van klinisch geriatrische problematiek

- ontwikkelingen in het funktioneren gedurende klinische behandeling van geriatrische patiënten

- de betekenis van geriatrische problematiek bij het risiko op overlijden

- de mogelijkheden die bepaalde instrumenten voor beoordeling en classificatie van geriatrische problematiek bieden in het perspektief van de uitkomsten van de zorgverlening.

Omwille van de duidelijkheid en om aan te geven binnen welke beperkingen en vrijheidsgraden dit onderzoek heeft plaats gevonden is hieraan toegevoegd een inleiding op de geriatrische zorg in Nederland in het algemeen en een beschrijving van het Flankerend Geriatrisch Beleid als specifieke organisatievorm van waaruit het onderzoek heeft plaatsgevonden in het bijzonder. Op dit laatste wordt met name teruggekomen in hoofdstuk 2. 


\section{Hoofdstuk 1}

\section{Geriatrie en geriatrie-voorzieningen}

\subsection{Vergrijzing en ontgroening}

De gemiddelde levensverwachting van de nederlandse bevolking is de afgelopen honderd jaar bijna verdubbeld. Een belangrijke oorzaak is het terugdringen van de vroegsterfte onder pasgeborenen en jonge kinderen. Echter, ook de levensverwachting van 65 -jarigen is er sterk op vooruit gegaan. Anno 1992 heeft een 65 -jarige nederlandse vrouw bijvoorbeeld nog een gemiddelde levensverwachting van bijna 20 jaar. Door veranderingen in het mortaliteitspatroon is het aantal mensen in de $8 \mathrm{e}, 9 \mathrm{e}$ of zelfs $10 \mathrm{e}$ levensdecade enorm gestegen.

De vergrijzing van de bevolking ofwel de toename van het aantal ouderen is een verschijnsel dat wereldwijd kan worden waargenomen. De sterkste toename is momenteel waarneembaar in de Derde Wereld. Hier wordt dit voor een belangrijk gedeelte veroorzaakt door de verbetering van de economische situatie en de daarmee samenhangende toename van het niveau en de bereikbaarheid van gezondheidszorgvoorzieningen (Koster, 1986).

Daarnaast is er op veel plaatsen in de wereld sprake van geboortebeperkende maatregelen. Hierdoor treedt een verschuiving op in de bevolkingsopbouw, die ertoe leidt dat het aantal ouderen zowel absoluut als percentueel stijgt. Vergrijzing en ontgroening zijn twee begrippen, die momenteel hand in hand gaan. De term bejaarde is weinig gedefinieerd. Wanneer in het vervolg van deze uiteenzetting wordt gesproken over ouderen, worden conform maatschappelijke realiteit bedoeld personen ouder dan 65 jaar. Onder hoogbejaarden wordt hier verstaan: personen ouder dan 80 jaar. De huidige prognose van het Centraal Bureau voor de Statistiek is weergegeven in tabel 1.1. Hieruit valt af te leiden, dat de totale Nederlandse bevolking tussen 1986 en 2035 niet of nauwelijks zal toenemen. In dezelfde periode neemt het aantal personen ouder dan 65 jaar toe van ruim $12 \%$ tot bijna $27 \%$ van de totale populatie. Deze vergrijzing heeft nog enkele bijzondere kenmerken. Ten gevolge van de voor vrouwen geldende hogere gemiddelde levensverwachting is in de opeenvolgende leeftijdscohorten een toenemend vrouwenoverschot waarneembaar. In de groep personen ouder dan 80 jaar, zo blijkt uit tabel 1.2, zal het aantal vrouwen in het jaar 2010 ruim 2.7 maal groter zijn dan het aantal mannen. 
Tabel 1.1 Aantal personen (in duizendtallen) van 65 jaar en ouder. Vooruitberekening 1986-2035.

\begin{tabular}{lrrrrrrrr}
\hline Leefijd & 1986 & 1990 & 1995 & 2000 & 2005 & 2010 & 2020 & 2035 \\
\hline $\begin{array}{lrrrr}\text { Mannen } \\
65-69\end{array}$ & 250 & 285 & 287 & 305 & 322 & 367 & 450 & 482 \\
$70-74$ & 199 & 199 & 238 & 240 & 255 & 270 & 395 & 413 \\
$75-79$ & 36 & 144 & 146 & 175 & 176 & 187 & 226 & 287 \\
$80-84$ & 78 & 82 & 88 & 89 & 107 & 108 & 121 & 169 \\
$85+$ & 47 & 51 & 54 & 58 & 59 & 68 & 76 & 112 \\
Totaal & 710 & 761 & 813 & 867 & 919 & 1000 & 1268 & 1463 \\
Vrouwen & & & & & & & & \\
$65-69$ & 305 & 345 & 336 & 341 & 348 & 391 & 494 & 536 \\
$70-74$ & 274 & 272 & 322 & 314 & 319 & 326 & 475 & 513 \\
$75-79$ & 223 & 239 & 241 & 286 & 279 & 283 & 325 & 431 \\
$80-84$ & 151 & 172 & 190 & 192 & 229 & 223 & 231 & 328 \\
$85+$ & 106 & 132 & 165 & 190 & 200 & 227 & 238 & 325 \\
Totaal & 1059 & 1160 & 1254 & 1323 & 1375 & 1450 & 1763 & 2133 \\
Totaal $65+$ & 1769 & 1921 & 2067 & 2190 & 2294 & 2450 & 3031 & 3596 \\
Totale & & & & & & & & \\
Bevolking & 14529 & 14724 & 14968 & 15147 & 15182 & 15075 & 14618 & 13361 \\
$\begin{array}{l}\text { Percentage } \\
\text { Bejaarden }\end{array}$ & 12,2 & 13,0 & 13,8 & 14,5 & 15,1 & 16,3 & 20,7 & 26,9 \\
\hline
\end{tabular}

Bron: CBS, 1990.

Tabel 1.2 Aantal vrouwen per 1000 mannen. Vooruitberekening 1986-2035.

\begin{tabular}{lllllllll}
\hline Leeftijd & 1986 & 1990 & 1995 & 2000 & 2005 & 2010 & 2020 & 2035 \\
\hline $65-69$ & 1271 & 1211 & 1171 & 1118 & 1081 & 1065 & 1098 & 1112 \\
$70-74$ & 1377 & 1367 & 1353 & 1308 & 1251 & 1207 & 1203 & 1242 \\
$75-79$ & 1643 & 1660 & 1651 & 1634 & 1585 & 1513 & 1438 & 1502 \\
$80-84$ & 1938 & 2098 & 2159 & 2157 & 2140 & 2065 & 1909 & 1941 \\
$85+$ & 2292 & 2588 & 3056 & 3431 & 3390 & 3338 & 3132 & 2902 \\
Totaal & 1492 & 1526 & 1544 & 1527 & 1496 & 1449 & 1389 & 1457 \\
\hline
\end{tabular}

Bron: CBS, 1990. 
Dit houdt impliciet in dat het aantal alleenstaanden, met name in het vrouwelijk bevolkingsdeel, toe zal nemen (Hazzard, 1986). Het aantal alleenstaanden neemt bovendien toe doordat ook op jeugdiger leeftijd het aantal mensen dat geen duurzame vorm van samenleving verkiest, sterk toeneemt.

Bij de (politieke) besluitvorming over de maatregelen die genomen moeten worden in verband met de toenemende vergrijzing moet niet alleen de gemiddelde levensduur en sterftekans per leeftijdsgroep worden betrokken maar ook de zogenaamde aktieve levensverwachting. Hiermee wordt bedoeld het aantal jaren dat personen lichamelijk en geestelijk onafhankelijk kunnen funktioneren. Op grond van de aldus verkregen cijfers kan vervolgens per leeftijdscategorie worden nagegaan wat het te verwachten aantal jaren van hulpbehoevendheid zal zijn op het niveau van het ADL-funktioneren (Activity of Daily Life) voor elke leeftijdscategorie (Katz e.a. 1983).

De gedachte dat ouderdom persé gepaard gaat met gebreken wordt o.a. weerlegd door Fries (1980) die op grond van trends in levensverwachting en morbiditeit heeft berekend dat de gemiddelde levensverwachting nog enigszins zal toenemen, maar dat de belangrijkste verandering in de nabije toekomst zal zijn een steeds verder terugdringen van morbiditeit en handicapvorming naar de allerlaatste levensjaren (van Proosdij e.a., 1988). Anders gezegd: de aktieve levensverwachting neemt toe en de periode van handicapvorming en chronische symptomatische morbiditeit wordt gecomprimeerd in de laatste levensjaren. In hoeverre een dergelijke "rectangularisatie" van de morbiditeits- en overlevingscurves ook daadwerkelijk zal optreden is vooralsnog onzeker. Schneider en Brody (1983) merken terecht op dat hiervoor op dit moment nog onvoldoende argumenten zijn. Volgens deze auteurs kan alleen door intensivering van preventieve gezondheidszorgprogramma's en een effectievere behandeling van chronische ziekten de door Fries veronderstelde ontwikkeling werkelijkheid worden.

De vergrijzing met de daaraan gekoppelde fenomenen van ontgroening, vervrouwelijking en individualisering, heeft belangrijke consequenties voor de samenleving als geheel, bijvoorbeeld op het gebied van onderwijs, woningbouw en sociale voorzieningen (Rowe e.a., 1987; Rango, 1982; Kane e.a., 1985). Omvang en behoeften van de verschillende doelgroepen veranderen. Tegelijkertijd zal de vergrijzing en ontgroening van invloed zijn op het financieel middelenkader, o.a. door een afname van het aantal mensen in de beroepssector die moeten zorgen voor het bruto-nationaal product. Ook in de gezondheidszorg zal de vergrijzing sterk merkbaar zijn (Hoogendoorn, 1984).

Als directe consequenties noemt Post (1987) o.a. een toename in de zorgvraag in de AWBZ-voorzieningen, een kostenstijging van $14-16 \%$ ten aanzien van de ziekenfondswet, een toenemende vraag naar o.m. huisartsen, internisten, cardiologen, longartsen en oogartsen, en een toenemende behoefte aan ziekenhuisbedden, tenminste indien het beleid zoals nu gevoerd, ongewijzigd blijft.

De rol die het ziekenhuis in de gezondheidszorg voor hoogbejaarden vervult, is de afgelopen decennia steeds belangrijker geworden (Hoogendoorn, 1978). 
Met name ziektebeelden samenhangend met atherosclerose zijn sterk in frequentie gestegen. Daarnaast is een duidelijke toename waarneembaar van ziektebeelden die op hoge leeftijd meer frequent voorkomen, zoals heupfrakturen (osteoporose), cataract, prostaatkanker, osteoarthrose, etc.

De vraag is overigens gerechtvaardigd of ouderen zelf wel steeds een beroep op deze vorm van gezondheidszorg willen doen.

In Nederland hebben de voorziene veranderingen mede geleid tot een groeiende aandacht voor verouderingsprocessen en specifieke gezondheidszorgaktiviteiten voor ouderen en uiteindelijk tot erkenning van de klinische geriatrie als afzonderlijk medisch specialisme.

De toename van de belangstelling van de medische beroepsgroep voor ouderen is op veel plaatsen in de wereld waarneembaar (Burley e.a., 1985; Buttler, 1979; Cape, 1979; Rowe e.a., 1987; Williamson, 1979). Dit wordt onder meer geillustreerd door het feit dat in de Verenigde Staten in 19884000 internisten deelnamen aan het examen voor een aantekening geriatrie, georganiseerd door de American Board of Internal Medicine en de American Board of Family Practice (Besdine, 1989).

\subsection{Gezondheidszorg en ouderen}

Basisprincipe van de medische praktijkvoering is sinds de $17 \mathrm{e}$ eeuw steeds geweest het zoeken naar de ziekte die ten grondslag lag aan de problemen van de patiënt. Behandeling van deze ziekte is dan de geëigende manier om de symptomen te doen verminderen of verdwijnen. Deze strategie is met veel succes gevolgd, hetgeen niet wegneemt dat er beperkingen aan verbonden zijn. Sommige klachten zijn onafhankelijk van "ziekte", eveneens zijn er talrijke "ziektes" die symptoomarm of zelfs symptoomloos zijn. Voorts zijn ernst en handicapvorming niet voorspelbaar uit de kennis omtrent de ziekte (Lawton e.a., 1983; Williams e.a., 1983). Deze uitspraken gelden zeker voor ouderen.

Om deze reden kan het scrupuleus zoeken naar "ziektes" averechts werken, bijvoorbeeld wanneer het gaat om hoogbejaarde patiënten met chronische aandoeningen. Bij dergelijke patiënten moet het doel feitelijk zijn het verbeteren van de funkties en het verhogen van de kwaliteit van leven tot een acceptabel niveau (Fillenbaum, 1985). Dit doel wordt doorgaans bereikt zonder dat de onderliggende ziekte kan worden genezen.

Lage rugpijn bijvoorbeeld is een bekend voorbeeld van een chronische aandoening waarbij de exacte diagnose slechts van beperkt belang is. Slechts zelden kan bij deze klacht een specifieke "te genezen aandoening" worden vastgesteld. Aanpassingen in de leefsituatie, oefentherapie en goeddeels symptomatische behandeling met analgetica of anti-inflammatoire middelen volstaat veelal om het funktioneren en de kwaliteit van leven van de patiënt te verbeteren. 
Bij de gezondheidszorg voor ouderen is het besef dat zij geen homogene groep vormen, maar in fysiologisch en psychosociaal opzicht sterk verschillen, van groot belang (Rowe, 1985). De progressieve leeftijdsgebonden achteruitgang van het funktioneren van talrijke organen en orgaanssystemen, gecombineerd met een afname van homeostasecapaciteit en toename van funktionele handicaps als gevolg van aanwezige chronische aandoeningen, leidt tot de toegenomen kwetsbaarheid van de oudere patiënt (Ramsey, 1983; Philips e.a., 1984).

Veroudering; als zodanig is geen ziekte en kan worden beschouwd als een fysiologisch proces dat echter niet zonder risico's is (Koster, 1986; Hooyman e.a., 1986). De hormonale veranderingen (menopauze) en de toename van atherosclerose zijn identificeerbare risicofaktoren (Applegate, 1989), gekoppeld aan veroudering, die predisponeren tot bepaalde aandoeningen zoals bijvoorbeeld osteoporose en cardiovasculaire ziekten (Boghasian e.a., 1987).

Een belangrijke faktor is voorts dat veel ouderen eerder geneigd zijn fysieke en psychische achteruitgang te accepteren als onvermijdelijk dan hiervoor medische hulp te zoeken (Lawton, 1975).

Ook het verminderd vermogen gevaar tijdig te onderkennen of effectief hierop te reageren draagt sterk bij aan de morbiditeit en mortaliteit bij ouderen (Lawton, 1975; Nelson, 1987). Meer dan de helft van alle overlijdensgevallen ten gevolge van lichamelijk letsel bij ouderen wordt veroorzaakt door vallen (Horn e.a., 1986; Lewis, 1981; Lipschitz, 1983). Hierbij spelen alcoholgebruik, visuele handicaps, hartritmestoornissen, gebruik van psychotrope geneesmiddelen, verblijf in een vreemde omgeving en osteoporose een belangrijke rol (Hogue, 1982; Hoogendoorn, 1982; Lewis, 1981; Nickens, 1985).

Twee andere fenomenen die de gezondheidszorg van ouderen kompliceren en leiden tot een verminderd zelfzorgvermogen zijn het voorkomen van multiple aandoeningen en de atypische of veranderde symptomatologie van ziekte (Deal, 1979; Garibaldi e.a., 1986; Gordon, 1987; Havard, 1981; Mader, 1984).

Alles tezamen leidt dit ertoe dat bejaarden vaker in het ziekenhuis worden opgenomen dan jongeren, terwijl ook hun gemiddelde verpleegduur langer is (Hoogendoorn, 1984; Campion e.a., 1983). Tussen 1967 en 1990 is in Nederland het aantal ziekenhuisbedden dat gemiddeld bezet werd door ouderen toegenomen van $23 \%$ tot $42 \%$ van het totaal aantal beschikbare bedden.

Ziekenhuisopname veroorzaakt bij bejaarden frequent verwardheid (Narain e.a., 1988), voedingsstoornissen (Morley e.a., 1988) en incontinentie (Ouslander e.a., 1986), zonder dat dit kan worden verklaard uit de gestelde diagnoses of de toegepaste therapie (Fiolet e.a., 1987; Gillick e.a., 1982). Dit leidt dan weer tot niet altijd even adequate medische interventie, zoals psychotrope medicatie, immobilisatie, fixatie, maagsondes en urinecatheters (Bliss, 1981; Cartwright e.a., 1988; Kale, 1984). Komplicaties van dergelijke "behandeling" zoals thromboflebitis, thrombose, longembolie, aspiratiepneumonie en urine- 
weginfekties komen naar schatting bij 25-30\% van deze patiënten voor (Gillich e.a., 1982; Gosney e.a., 1984).

Geriatrische problematiek vereist principieel een multidisciplinaire aanpak (Fillenbaum, 1985). Grensoverschrijdend werken is noodzakelijk evenals een zogenaamde totaallbenadering (Passchier e.a., 1984).

\subsection{De complexiteit van ziekte en zorgvraag}

Hoewel er geen "echte" ouderdomsziekten bestaan geldt voor talrijke aandoeningen dat de frequentie van voorkomen toeneemt met de leeftijd. Toeneming van het aantal ouderen betekent derhalve toeneming van de incidentie van ziekte. Het is een misvatting te veronderstellen, dat oud worden onontkoombaar gepaard gaat met ziekte. Uit algemene gezondheidsstatistieken blijkt, dat ongeveer $70 \%$ van de oudere bevolking een goede gezondheid geniet en geen behoefte heeft aan specifieke gezondheidszorgvoorzieningen (Schneider e.a., 1983,1985). Bij gelijkblijvende incidentiecijfers zal echter voor tal van aandoeningen gelden, dat een verdubbeling van het aantal ouderen eveneens betekent een overeenkomstige toename van het aantal patiënten dat aan een bepaalde ziekte lijdt.

Voor veel aandoeningen, voorkomend op oudere leeftijd, geldt dat genezing in absolute zin niet mogelijk is. Deze chronische aandoeningen behoeven veelal intensieve medische begeleiding. Het gevolg is dat indien het aantal ouderen groeit, ook de gemiddelde behoefte aan de medische begeleiding toeneemt. De kans op het gelijktijdig voorkomen van meerdere aandoeningen (co-morbiditeit) wordt evenzeer hierdoor beïnvloed (van Horn e.a., 1986). Nieuwe medische ontwikkelingen, ertoe leidend dat chronische aandoeningen langer beheersbaar blijven in medisch opzicht, zijn een andere faktor. Het veelvuldiger voorkomen van chronische aandoeningen zal het aantal patiënten met handicaps waarvoor speciale voorzieningen noodzakelijk zijn doen stijgen (Rowe, 1985).

Het fenomeen van meerdere al dan niet chronische aandoeningen, gecombineerd met de groei van medisch-technische mogelijkheden en de uitbreiding van het therapeutisch arsenaal, heeft als gevolg een grotere behoefte aan multidisciplinaire benadering. Ook leidt dit tot een toename van de behoefte aan voorzieningen gericht op chronische hulpverlening, zowel in de ambulante sector als op het niveau van geïstitutionaliseerde zorgverlening.

Een belangrijke determinant bij de planning van voorzieningen is de mate waarin mantelzorg (Knipscheer e.a., 1991) al dan niet kan worden gerealiseerd. Het zal duidelijk zijn, dat naast complexiteit van de ziekte ook het sociale draagvlak medebepalend is voor de keuze tussen ambulante en geïnstitutionaliseerde zorg. De toename van het aantal hoogbejaarde alleenstaanden is in dit verband van bijzondere betekenis. 
De toename van het aantal bejaarden en hoogbejaarden betekent in absolute zin eveneens een toename van het aantal patiënten bij wie, naast specifieke aandoeningen, ook in meer algemene zin, sprake is van een afname van mobiliteit, zelfzorgvermogen en mentaal funktioneren (Sabin, 1982). Dit leidt tot een groeiend aantal ouderen, die hierdoor afhankelijk zijn van derden, en in praktisch opzicht betekent dit ook dat de gemiddelde tijd die moet worden besteed aan probleemverheldering, diagnostiek en uitvoering van behandeling zal toenemen. Per tijdseenheid zal hierdoor het aantal consultaties en handelingen waartoe de hulpverlener in staat is, afnemen. Dit verklaart waarom in prognoses omtrent de behoefte aan voorzieningen het niet mogelijk is simpelweg de groeifaktor van de oudere bevolkingsgroep te benutten als variabele bij het bepalen van de te verwachten groei. De afname van mobiliteit, zelfzorgvermogen en mentaal funktioneren zal eveneens specifieke eisen stellen aan de inrichting van de voorzieningen in materieel opzicht.

\subsection{Zorgdifferentiatie}

Tot nu toe is uitsluitend gesproken over ouderen in het algemeen. Zoals gezegd, vormen die in meerdere opzichten geen homogene groep. Eén van de wijzen, waarop onderscheid gemaakt kan worden, is een indeling in groepen, die worden gekenmerkt door de funktionele eisen die worden gesteld aan de gezondheidszorgorganisatie. Op deze wijze kunnen drie hoofdgroepen worden onderscheiden.

De eerste groep, waartoe naar schatting $70 \%$ van de ouderen behoort, wordt gevormd door degenen bij wie in geval van ziekte weinig of geen specifieke problemen aanwijsbaar zijn, die samenhangen met de leeftijd waarop de betreffende aandoening zich manifesteert: bijvoorbeeld een urineweginfektie bij een verder gezonde 80 -jarige vrouw. Conventionele niet leeftijdsgebonden aanpak zal hier tot een bevredigend resultaat leiden.

De tweede groep omvat ouderen bij wie meer complexe medische problematiek aanwezig is maar bij wie deze problematiek geen vergaande consequenties heeft ten aanzien van het funktioneren als geheel. Geëigende maatregelen zullen een voorspelbaar resultaat opleveren waarbij de prognose wordt bepaald door de specifieke aandoeningen; bijvoorbeeld een maagulcus bij een 80 -jarige man, die behandeld wordt met NSAID's in verband met rheumatoide arthritis. Indien aan bepaalde voorwaarden wordt voldaan behoeft geen blijvende verstoring van het funktioneren als geheel te worden verwacht.

De derde groep bestaat uit de zogenaamde geriatrische patiënten. Een geriatrische patiënt is (doorgaans) een oudere patiënt(e), met een labiel evenwicht tussen somatisch, psychisch en sociaal funktioneren. Bij hem of haar zal een, 
al dan niet, intercurrente aandoening een dusdanige verstoring van het evenwicht veroorzaken dat blijvende hulpbehoevendheid dreigt te ontstaan.

Systeemtheoretisch kan het wankel evenwicht bij geriatrische patiënten worden beschreven als de som van de interacties tussen een patiënt en de anderen in zijn omgeving waarbij (psychosociaal) gedrag over en weer, zelfzorg en zorgverlening de determinanten vormen (Sipsma, 1986).

De verstoorde interactie tussen de patiënt en zijn of haar omgeving, als gevolg van het tekortschieten van het zelfzorgvermogen, door fysieke handicaps of veranderd psychosociaal gedrag van de patiënt, of het tekortschieten van zorgverlening door fysiek onvermogen of emotionele weerstand van "significant others" speelt vaak een luxerende rol en leidt tot de steeds weerkerende verstoring van het evenwicht (Anderson e.a., 1984).

Bij het ontstaan van fysieke handicaps en stoornissen in het psychosociaal gedrag speelt veroudering een belangrijke rol. Bijvoorbeeld de veroudering van het centraal zenuwstelsel, het sleutelorgaan in de regulatie van homeostatische processen en voor de interactie tussen mens en omgeving (Spirduso, 1980).

Deze derde groep, de geriatrische patiënten, betreft naar schatting 5-10\% van de oudere bevolking. Dit betekent dat momenteel in Nederland 75.000150.000 ouderen zijn, die aan deze definitie voldoen.

Naast de "algemene" weinig beeldende elementen uit de definitie is in concreto frequent sprake van mobiliteitsstoornissen, stoornissen in de communicatie, in het psychisch en/of intellectueel funktioneren, in de mictie en/of de defaecatie, voorts van een verminderd zelfzorgvermogen en van een ontoereikend sociaal netwerk.

Dit onderstreept nogmaals de noodzaak tot gedifferentieerde zorg.

\subsection{De geriatrische zorg}

Reeds voor de Tweede Wereldoorlog heeft de onderkenning van specifieke verzorgingsproblematiek en een behoefte aan aangepaste medische behandeling in Engeland geleid tot de eerste specifieke aanpassingen in de gezondheidszorg voor ouderen. De beroemdste pionier in de geriatrie is ongetwijfeld de Engelse chirurg Marjorie Warren (Andrews e.a., 1988). Zij kreeg de verantwoordelijkheid voor een verpleeghuis voor armen met honderden bedlegerige, chronisch zieke en voor het merendeel oude patiënten. Voor velen bleek, dankzij correcte diagnostiek en "active treatment" genezing of vergaande funktieverbetering mogelijk. Op grond van haar ervaring ontstond zo het concept van de klinische geriatrie en zijn momenteel in Engeland ruim 500 "consultant geriatricians" werkzaam.

Uit recent onderzoek van Andrews en Brocklehurst (1988) blijkt echter dat, hoewel het Engelse model wereldwijd is geaccepteerd als basisconcept voor het specialisme geriatrie, er ook daar grote verschillen bestaan in de wijze waarop een geriatrische afdeling of voorziening is gestructureerd. Deze ver- 
schillen betreffen de materiële voorzieningen, de medische staf, de para-medische medewerkers, de opnamecriteria, de relatie tussen acute, revalidatieen verblijfsafdelingen, de integratie met de interne geneeskunde, de verhouding met andere specialismen, etc. De discussie over de plaats van geriater en geriatrie in de gezondheidszorg is ook in Engeland bepaald niet afgerond (Andrews e.a., 1988; Burley e.a., 1985; Stewart e.a., 1989; Woodhouse, 1989; Young, 1989).

Een experiment in Newcastle upon Tyne wees uit dat de integratie van geriatrische patiëntenzorg met acute medische zorg de kwaliteit van de gezondheidszorg als geheel verbeterde, terwijl het gebruik van algemene ziekenhuisbedden optimaliseerde (Grimley Evans, 1983). Als bijkomend voordeel vermelden de auteurs de vermindering van de geïsoleerde positie van geriaters ten opzichte van de overige ziekenhuisspecialisten. Hierdoor wordt het specialisme ook aantrekkelijker voor jonge artsen die een keuze moeten maken ten aanzien van hun verdere specialisatie.

Door Evans e.a. (1989) is integratie met de (algemene) interne geneeskunde sterk gepropageerd. Anderen daarentegen bepleiten verdere verzelfstandiging van de geriatrische afdelingen. Hoe dan ook, specifieke voorzieningen voor ouderen geïntegreerd in het algemeen ziekenhuis zoals o.a. beschreven door Mitchell e.a. (1987) kunnen leiden tot een reductie van de opnameduur, een verbeterde bedbezetting, een vermindering van de wachtlijst en tot een belangrijke kostenreductie.

In de literatuur zijn talrijke studies voorhanden die specifieke geriatrische voorzieningen en het effect daarvan beschrijven (McVey e.a., 1989; Mitchell e.a., 1987; Rubenstein e.a., 1984; Williams e.a., 1987; Apllegate e.a., 1987,1990; Saltz e.a., 1988).

\subsection{De zelfstandige geriatrische afdeling}

Het rendement van specifieke afdelingen voor geriatrische patiënten, zoals de geriatrische evaluatie unit en de gecombineerde evaluatie/ rehabilitatie unit (in Nederland bekend als een zgn. GAAZ), is in de literatuur overtuigend aangetoond: de overleving verbetert, de medische kosten op jaarbasis per patiënt verminderen en de behoefte aan bedden voor acute opnames en verpleeghuizen neemt af. Het is overigens niet ondenkbaar dat patiëntenselectie heeft bijgedragen tot deze positieve uitkomsten (Solomon, 1988).

Een van de bekendste studies is het onderzoek van Rubenstein e.a. (1984). Patiënten die zijn behandeld in de zogenaamde geriatrische evaluatie unit, qua structuur vergelijkbaar met een GAAZ-afdeling, hebben een significant lagere mortaliteit en worden minder frequent ontslagen naar een verpleeghuis of heropgenomen, dan vergelijkbare contrôlepatiënten die niet op deze geriatrische evaluatie-unit waren opgenomen. Funktieverbetering wordt eveneens significant vaker waargenomen. Deze unit is getypeerd als "intermediate-care ward". De gemiddelde verblijfsduur van de patiënten is $\mathbf{4 3}$ 
dagen. Toch zijn er nogal wat bezwaren aan te voeren tegen deze studie. Er is in sterke mate sprake van patiëntenselectie. Van de 3140 patiënten waarvan wordt uitgegaan valt $54 \%$ af omdat zij minder dan één week in het ziekenhuis verblijven of binnen één week overlijclen. Patiënten met vergevorderde dementie of andere vergevorderde chronische aandoeningen en patiënten in de terminale fase van ernstige somatische ziektes, worden eveneens uitgesloten. Ook patiënten bij wie het sociaal netwerk geen garantie geeft op mogelijke terugplaatsing naar de eigen woonsituatie vallen buiten het onderzoek. Uiteindelijk blijven slechts 123 patiënten $(4 \%)$ over die gerandomiseerd worden naar wel of geen behandeling in de geriatrische evaluatie unit. De sterke patiëntenselectie heeft geen directe consequenties voor de gevonden verschillen, maar roept wel vragen op aangaande de te verwachten resultaten van een dergelijke unit in de "gewone" geriatrische patiëntenzorg. De periode waarin de patiënten zijn verzameld, beslaat 30 maanden, wat neerkomt op een instroom van 4 patiënten per maand (!). Een ander probleem bij het extrapoleren van de resultaten is dat de studie is verricht in een "veterans hospital": $95 \%$ van de patiënten waren mannen.

Lefton e.a. (1983) hebben het succes van een specifieke geriatrische afdeling, een zogenaamde klinische geriatrische unit in een revalidatie instelling onderzocht. Deze geriatrische unit bestond uit 14 bedden. Een multidisciplinaire behandelteam was verantwoordelijk voor de behandeling. Dit bestond uit twee algemene verpleegkundigen, één speciale geriatrische verpleegkundige, een fysiotherapeut, een bezigheidstherapeut, een logopediste, een maatschappelijk werker, een diëtiste en twee internisten. Alle patiënten ouder dan 70 jaar die in staat werden geacht een reaktivatieprogramma te volgen werden opgenomen in de studie. $\mathrm{Zij}$ waren verwezen door algemene ziekenhuizen weken tot maanden na opname aldaar. De meeste hadden ernstige mobiliteitsstoornissen naast multiple aktieve chronische ziekten. Specifieke geriatrische kenmerken worden in de studie niet vermeld. Een vergelijking werd gemaakt tussen ouderen die in deze specifieke ouderen-unit zijn behandeld en ouderen die in andere afdelingen van hetzelfde instituut in groepen waar ook jeugdigere patiënten deel van uitmaakten worden behandeld. Randomisatie of beter gezegd de verdeling van de patiënten gebeurde op basis van de beschikbaarheid van bedden in de ene danwel de andere behandelingsmogelijkheid. Ouderen die in de specifieke geriatrische unit verbleven bleken vaker te kunnen worden ontslagen naar de oorspronkelijke woonsituatie, waren beter mobiel, meer ADL-zelfstandig en mogelijk minder verward, beter geörienteerd en vaker continent. Een specifieke verklaring voor dit verschil anders dan de setting waarin de behandeling had plaatsgehad kon niet worden gevonden.

Volgens Lefton kan een belangrijk aspect zijn geweest dat de medische staf niet at random was geselecteerd maar voor de klinische geriatrische unit was 
aangetrokken op basis van specifieke belangstelling voor geriatrische problematiek.

Het effect van een zogenaamd "geriatrisch consultatieteam" is o.a. onderzocht door McVey en Becker (1989). Dit consultatieteam bestond uit een geriater, een geriatrisch verpleegkundige en een maatschappelijk werker. Bij patiënten ouder dan 75 jaar is door hen een multidimensionale evaluatie gedaan, gericht op het opsporen van o.a. ADL-stoornissen, depressie, cognitieve funktiestoornissen en occult alcoholisme. $\mathrm{Na}$ randomisatie is de helft van de patiënten intensief vervolgd, waarbij adviezen gebaseerd op de resultaten van de evaluatie uitvoerig zijn besproken met de behandelaars. Het consultatieteam participeerde niet in de verdere behandeling van de betrokken patiënten. Bij de andere helft van de patiënten is geen verdere aktie ondernomen en is afgewacht wat de uitkomst van conventionele behandeling was. Overigens blijkt nergens uit de gegevens dat het hier speciaal geriatrische patiënten betreft. Uit deze studie blijkt dat geen significant verschil bestaat tussen patiënten die wel en niet verder vervolgd zijn. In de conclusie wordt gespeculeerd dat een dergelijke interventie mogelijk wel succesvol zou zijn geweest indien niet slechts adviezen waren gegeven, maar ook daadwerkelijk gerichte aktie was ondernomen.

\subsection{De geriatrie in nederland}

In Nederland worden als het begin van de geriatrie vaak genoemd de aktiviteiten van de internist Prof. Dr. J.Th. Schreuder, in het begin van de jaren vijftig. Aanvankelijk in Friesland, later in Hilversum, waar hij nauw betrokken was bij de ontwikkeling van de geriatrische afdeling van het Ziekenhuis Zonnestraal. Al voor zijn komst naar Hilversum was hier in 1953 door de internist E.R.R. Rinkes een geriatrische afdeling opgezet, gebaseerd op door hem in Engeland opgedane ervaringen (v.Proosdij, 1977).

Deze afdeling voorzag in een dermate grote behoefte dat binnen enkele jaren het beddenaantal meer dan 200 bedroeg. In de dertig jaren die volgden zijn herhaalde, veelal moeizame pogingen gedaan de geriatrie als specialisme officieel erkend te krijgen. Onder leiding van wijlen Prof. Dr. Van Nieuwenhuizen heeft dit in 1982 uiteindelijk geleid tot een door het Centraal College erkende opleiding tot klinisch geriater. In de periode daaraan voorafgaand is in een aantal ziekenhuizen een zogenaamde Geriatrische Afdeling Algemeen Ziekenhuis (GAAZ) opgericht, bedoeld als specifieke locatie voor specialistische klinisch geriatrische zorg. Een meer uitgebreid overzicht van de "geboorte en lijdensweg" van de klinische geriatrie is te vinden in de publicaties van Van Proosdij $(1977,1984)$.

Tussen 1953 en 1989 werden in Nederland in zeven algemene ziekenhuizen klinisch-geriatrische afdelingen opgericht, de zogenaamd GAAZ'en en wel in de volgende ziekenhuizen: St. Johannes de Deo in Haarlem, het Slotervaart 
Ziekenhuis in Amsterdam, Stichting Streekziekenhuis in Hilversunn (het voormalige "Zonnestraal"), het Gemeenteziekenhuis in Arnhem, het Maasland Ziekenhuis in Sittard, de Stichting Streekziekenhuis Gooi-Noord (voorheen Sint Jan Rijnstate Hooglaren) en het Scheper Ziekenhuis te Ernmen. Anno 1993 zijn in een aantal andere algemene ziekenhuizen geriatrische aktiviteiten gaande, waarvan sommige met de bedoeling dat dit zal leiden tot een GAAZ-afdeling. De belangrijkste stap voorwaarts bij de landelijke invoering van de klinische geriatrie is het besluit van de overheid in 1988 te streven naar de oprichting van één GAAZ per gezondheidsregio. Sindsdien zijn er al diverse nieuwe GAAZ'en opgericht. Dit betekent dat in Nederland uiteindelijk 27 GAAZ'en zullen komen.

Zonder in te gaan op de logistieke consequenties, die deze besluitvorming met zich brengt, is het gewenst de funktie van een GAAZ en de voor- en nadelen die hieraan verbonden zijn nader te omschrijven.

Door Remmerswaal (1982) zijn een aantal voorwaarden gesteld bij de realisering van een GAAZ. Als doelgroep van de GAAZ noemt deze auteur "alle oudere patiënten voor wie het normale zorgkader tekort gaat schieten" en "voor wie er reden is om een bedreiging van het totale evenwicht (primair somatisch, maar vaak ook sociaal en psychisch) te vrezen".

Hij acht om redenen van continuïteit een team van 2 of 3 geriaters noodzakelijk, een afdelingsgrootte van minimaal 20 bedden en een poliklinische voorziening. Uroloog, neuroloog, internist en algemeen chirurg behoren tot de "vaste dagelijkse consulenten", ook psychiater, tandarts en radioloog zijn frequente consultatiegevers.

Fysiotherapie, ADL-therapie en bezigheidstherapie worden betrokken vanuit de ziekenhuisorganisatie. Een klinisch psycholoog verbonden aan de afdeling is eveneens zeer gewenst.

$B i j$ de selectie van de verpleegkundigen voor een dergelijke afdeling zijn naast A-verpleegkundigen ook B-verpleegkundigen noodzakelijk, mede in verband met de veel voorkomende psychogeriatrische problematiek.

De wijze waarop de bestaande geriatrische afdelingen (GAAZ) organisatorisch en materieel zijn ingericht voldoet niet steeds aan de door Remmerswaal geformuleerde voorwaarden en is niet in alle opzichten uniform. Uit het NZI onderzoek "Geriatrische afdelingen in algemene ziekenhuizen" (1986) komt naar voren dat het doorgaans gesloten afdelingen betreft. Bouwkundig zijn vooral aanpassingen van sanitaire ruimtes ten behoeve van oudere gehandicapte patiënten gerealiseerd. Daarnaast is extra ruimte en/of aandacht gegeven aan de dagverblijven van de patiënten. In enkele gevallen beschikt een dergelijke afdeling over een eigen oefenruimte ten behoeve van fysiotherapie of ergotherapie.

Alle bestaande afdelingen hanteren het uitgangspunt dat multidisciplinair en in teamverband wordt gewerkt. De samenstelling van deze teams die bestaan uit medische, sociaal-wetenschappelijke, paramedische en verpleegkundige 
disciplines aangevuld met administratief personeel, keukenpersoneel en/of een hostess, loopt nogal uiteen. De verschillen worden voor een deel bepaald door kwalitatieve aspecten zoals het al dan niet aan de afdeling verbonden zijn van een neuroloog, een psychiater of een psycholoog. Daarnaast bestaan duidelijke kwantitatieve verschillen in het aantal medewerkers van een bepaalde discipline die beschikbaar zijn "per bed". De leiding van de afdeling en de coördinatie van de patiëntenbesprekingen berust doorgaans bij de aanwezige (internist-)geriater (s) (gemiddeld 1 à 2 per locatie).

Iedere GAAZ heeft de beschikking over een maatschappelijk werkende of sociaal verpleegkundige. De fysiotherapeut is niet specifiek aan de GAAZ verbonden, zodat meerdere therapeuten vanuit een centrale dienst voor een deel van hun tijd op de GAAZ ingezet kunnen zijn.

Ergotherapeuten zijn op vrijwel alle GAAZ'en aanwezig, evenals bezigheidstherapeuten.

Het aantal verpleegkundigen en ziekenverzorgenden varieert van 63 tot $87 \mathrm{fte}$ per 100 bedden, inclusief leerling verpleegkundigen.

Een uitgebreide bespreking van het ontstaan en funktioneren van een GAAZ is o.a. te vinden in publicaties van De Fockert (1983 (3x), 1984), Van Den Ouwelen-Persijn e.a. (1983) en Paschier e.a. (1984).

Er zijn enkele experimentele poliklinieken voor patiënten met complexe geriatrische problematiek. Genoemd kunnen worden de ouderenpolikliniek van het ziekenhuis in Hoogeveen (Twilhaar, 1988) waar oudere patiënten in één dag poliklinisch onderzocht kunnen worden door een aantal specialisten en het multidisciplinair geriatrisch consult voor de huisarts in Maastricht, waar patiënten binnen het bestek van één dagdeel algemeen internistisch, psychiatrisch, neurologisch en neuropsychologisch worden onderzocht. Voor beide voorzieningen geldt dat zij een diagnostisch probleemverhelderend karakter hebben en dat de continuïteit van zorg in handen blijft van de huisarts. Herhalingsbezoeken zijn dus niet geprogrammeerd.

Naast deze geriatrische funkties in een algemeen ziekenhuis moeten apart worden vermeld de Geriatrische Afdelingen in Psychiatrische Ziekenhuizen (GAPZ). Een dergelijke afdeling richt zich met name op patiënten bij wie én psychiatrische én somatische problematiek aanwezig is (van Nieuwkerk, 1984). Het gaat vooral om psychische stoornissen die na het 65 e levensjaar zijn ontstaan. De bijzondere aard van deze problematiek blijkt onder meer uit het hoge percentage patiënten dat wordt ontslagen naar een psychogeriatrisch verpleeghuis (55\%).

\subsection{Voor- en nadelen van een geriatrische afdeling (GAAZ).}

Een bespreking van de voor- en nadelen van een GAAZ is vanzelfsprekend nooit volledig. Veranderingen in het beleid van de overheid, bijzondere locale 
omstandigheden, verschillen in patiëntenstroombeheersing en verschillen in ervaring met bepaalde vormen van geriatrische zorgverlening zijn slechts enkele meer algemene variabelen die van invloed kunnen zijn op de gedachtenbepaling. Het is dan ook niet de bedoeling een definitief oordeel over de GAAZ-structuur uit te spreken. Gepoogd wordt slechts aan te geven dat de GAAZ niet a priori als de enige mogelijke vorm van klinische geriatrische zorgverlening moet worden beschouwd.

\section{Voordelen van de GAAZ}

De inrichting en personele organisatie van een GAAZ-afdeling is binnen de beschikbare middelenkaders optimaal afgestemd op de specifieke noden en behoeften van geriatrische patiënten (Golüke-Willemse e.a., 1987). Bij de inrichting kan het hierbij zowel ruimtelijke voorzieningen betreffen, zoals bijvoorbeeld één of meerdere dagverblijven of een eigen oefenzaal, als de wijze waarop deze ruimtes zijn geoutilleerd: speciale stoelen, aangepaste bedden, speciale vloerbedekking (Willmott, 1986), etcetera. Naast een wijze van inrichten die rekening houdt met veel voorkomende handicaps zoals slechte mobiliteit, visusstoornissen en incontinentieproblematiek wordt gestreefd naar een sfeer die aansluit bij de culturele achtergrond en belevingswereld van oudere patiënten. Dit laatste verschilt vanzelfsprekend individueel en kan in de loop der jaren ook aan verandering onderhevig zijn. Het personeel van een GAAZ heeft naast algemene professionele kennis en vaardigheden bijzondere belangstelling en deskundigheid op het gebied van de geriatrische patiëntenzorg. Verwacht kan worden dat een dergelijke "geriatrische motivatie" doorklinkt in de wijze waarop patiënten worden benaderd en een vruchtbare voedingsbodem vormt voor multidisciplinaire behandeling (Bruyns, 1984). Hierbij speelt de mogelijkheid van intensieve en deskundige observatie van geriatrische problematiek (Verstraten, 1988), zoals nachtelijke onrust, mobiliteitsstoornissen, incontinentie, depressief gedrag, desoriëntatie, etcetera, een belangrijke rol en bestaat een gunstig klimaat voor de hiermede verband houdende speciale trainingsprogramma's.

De afdeling biedt de gelegenheid om patiënten, elders in het ziekenhuis opgenomen, waarbij problemen ontstaan in de behandeling ten gevolge van geriatrische problematiek over te plaatsen naar een meer passende omgeving. Een eenvoudig maar belangrijk aspect hierbij is de mogelijkheid de afdeling een "gesloten" karakter te geven. Hierdoor kan beter worden omgegaan met frequent voorkomende problemen als wegloopgedrag en zwerfneiging.

De op de afdeling werkzame paramedici kunnen, ook al zijn zij niet uitsluitend werkzaam ten behoeve van de GAAZ, gemakkelijk participeren in het multidisciplinaire behandelteam en, indien gewenst, een deel van de therapie in groepsverband uitvoeren.

Tempo en intensiteit van de behandeling zijn, bijna vanzelfsprekend, afgestemd op de aanwezige patiëntenpopulatie en worden door de klinische 
geriater als hoofd van de afdeling gecoördineerd (de Fockert, 1982). Zijn aanwezigheid garandeert ook in andere opzichten dat geriatrische kennis en kunde gecontroleerd wordt aangewend binnen de afdeling.

Waar het gaat om opleiding van verpleegkundigen, paramedici en medici, die zich verder willen specialiseren in de geriatrie, kan de GAAZ bovendien een belangrijke plaats innemen als locatie voor (oriënterende) stages, praktische scholing en opleiding.

\section{Nadelen van de GAAZ}

Het feit dat patiënten, opgenomen in een GAAZ, worden geïsoleerd van de overige patiënten en als zodanig in meer of mindere mate worden gestigmatiseerd is een nadeel van deze organisatiestructuur. Dit is vergelijkbaar met de situatie van patiënten in een psychiatrische afdeling van een algemeen. ziekenhuis (PAAZ) of patiënten in een categoraal ziekenhuis (bijvoorbeeld een psychiatrische inrichting).

De capaciteit van de GAAZ is beperkt, waardoor hoge eisen worclen gesteld aan het opname- en ontslagbeleid. Zelfs onder optimale werkomstandigheden - zeker gelet op de huidige omvang van het aantal beschikbare GAAZbedden - bestaat er volstrekt onvoldoende ruimte om alle patiënten die geriatrische zorg behoeven ook daadwerkelijk op te nemen in een GAAZ. Uitgaande van een behoefte van 3 geriatrische bedden per 1000 inwoners ouder dan 65 jaar is momenteel behoefte aan 4500 geriatrische bedden in Nederland, ofwel 188 GAAZ'en met een gemiddelde capaciteit van 24 bedden. Afgaande op de eerder genoemde prognoses van het Centraal Bureau voor de Statistiek zal dit oplopen tot ruim het dubbele aantal over veertig jaar. Dit betekent bij een gemiddelde bezetting per afdeling met 1,5 klinische geriaters dat de komende veertig jaar bijna 550 geriaters moeten worden opgeleid, om deze afdelingen te "bemensen". Hierbij is geen rekening gehouden met het feit dat in dezelfde periode door pensionering en andere vormen van uitstroom ook nog een aantal "vervangers" moet worden opgeleid. Dit terwijl de huidige opleidingscapaciteit neerkomt op een instroom van drie geriaters per jaar en dus ver achter zal blijven bij deze behoefteraming. Het recente voornemen het aantal GAAZ'en in Nederland tot één GAAZ per gezondheidsregio uit te breiden is ondanks de beperkte beddenuitbreiding die dit oplevert, al voldoende om te komende tien tot vijftien jaar bijgelijkblijvende opleidingscapaciteit een enorm tekort aan beschikbare klinische geriaters te mogen verwachten. Tegelijkertijd zal in het licht van bovenstaande raming een geweldig tekort aan geriatrische bedden blijven bestaan.

Wanneer per gezondheidsregio slechts één GAAZ beschikbaar is leidt dit in veel gevallen tot een ongewenst grote afstand tussen de woonplaats van de patiënt en het ziekenhuis waar hij of zij kan worden behandeld. De spreiding van de klinische geriatrie is op deze wijze zuiver geografisch gezien gereali- 
seerd, maar het merendeel van de Nederlandse ziekenhuizen zal geen klinische geriatrische voorzieningen hebben.

Bij de bepaling van de effectieve capaciteit van de GAAZ-afdelingen moet daarnaast terdege rekening worden gehouden met de (on)mogelijkheden tot doorstroming van patiënten naar verzorgingstehuizen en verpleeghuizen. Mede door de voortdurende dreiging dat andere specialismen "uitbehandelde patiënten proberen te dumpen" op de GAAZ, hoe goed de criteria voor patiëntenselectie ook zijn, zal deze verkeerde bedden problematiek meer dan in andere ziekenhuisafdelingen van grote invloed zijn op de beschikbare bedden.

Een probleem van geheel ander orde is de discussie die ontstaat over opnamebeleid en wie de eerst verantwoordelijke behandelaar is, wanneer bij patiënten met geriatrische problematiek tevens - zoals zo vaak - sprake is van specifieke orgaanaandoeningen (de Fockert, 1984). Het gevaar is hierbij levensgroot dat acute gezondheidszorgproblematiek voor een belangrijk deel buiten de GAAZ blijft in ruil voor intermediate care of (sub)chronische zorgverlening wat het karakter van de GAAZ als ziekenhuisafdeling ongunstig beïnvloedt.

Ook als patiënten met identificeerbare acute orgaanproblematiek wel direct op de GAAZ worden opgenomen zal een dilemma ontstaan. Veelvuldig voorkomen van internistische, neurologische en/of psychiatrische problematiek, waarin de klinische geriater minder intensief is geschoold dan de betreffende specialist, leidt ertoe dat ofwel de kwaliteit van zorg op deze gebieden minder is, ofwel dat zeer frequent dergelijke specialisten moeten worden geraadpleegd. Dit veroorzaakt een situatie die door de GAAZ had moeten worden voorkomen, namelijk dat de patiënt gezien de problematiek wordt behandeld op de verkeerde afdeling.

De doelstelling van klinisch geriatrische zorg is het optimaliseren van de zorg voor geriatrische patiënten in het ziekenhuis. In essentie betekent dit dat zonder afbreuk te doen aan de inspanningen van de bestaande specialistische zorg gezorgd wordt voor een geheel van complementaire aktiviteiten die de zorg een meer holistisch karakter geven en recht doen aan de specifieke behoeften en noden van geriatrische patiënten. Door de bestaande zorg voor de betreffende patiëntengroep volledig te substitueren gaat onnodig veel geriatrische menskracht en middelen verloren ten behoeve van het uitvoeren van de basale gezondheidszorgaktiviteiten die ook zonder specifieke geriatrische inbreng reeds plaatsvindt in de ziekenhuizen. Isolatie van de geriatrische patiëntengroep ten opzichte van de specialismen en specialisten die van oudsher sterk gericht zijn op de klinische zorg voor oudere patiënten, waaronder zoals eerder genoemd de interne specialismen, de neurologie en de klinische psychiatrie zal ertoe leiden dat de noodzakelijke kennisvermeerde- 
reing binnen deze beroepsgroepen ten aanzien van geriatrische problematiek niet of onvoldoende wordt gerealiseerd, terwijl de bestaande expertise op dit gebied terzijde wordt geschoven. Een alternatief voor een dergelijk substitutie-effect kan gevonden worden door de geriatrische zorg niet in plaats van maar in samenwerking met de bestaande zorgverlening te realiseren. Consultatie en/of medebehandeling is binnen de ziekenhuisorganisatie de klassieke oplossing voor patiëntenproblematiek die het deskundigheidsgebied van één specifiek specialisme overstijgt. Flankerend Geriatrisch Beleid, het geriatrisch consultatiemodel waarover in hoofdstuk II verder wordt uitgeweid is een voorbeeld van een dergelijke oplossing.

Introductie van een GAAZ betekent voor de ziekenhuisorganisatie ook dat menskracht en middelen moeten worden onttrokken aan het bestaande budget, omdat in financieel en materieel opzicht aanzienlijke investeringen moeten worden gepleegd. Voor de organisatie betekent dit voorts een extra stuk departementalisatie, met als gevolg een reductie van beschikbare menskracht voor "algemene doeleinden". 


\section{Flankerend Geriatrisch Beleid}

De in het vorige hoofdstuk genoemde voor- en nadelen van de organisatie van geriatrische patiëntenzorg geconcentreerd in een GAAZ-structuur, doen de vraag rijzen in hoeverre er andere behandelingsmodaliteiten zijn te realiseren. Daarbij moet worden geanticipeerd op de nadelen van de GAAZ en op de groeiende behoefte aan meer specifieke zorg voor ouderen. Dit heeft geleid tot het concept van het Flankerend Geriatrisch Beleid (FGB).

Het Flankerend Geriatrisch Beleid vormt een geheel van niet afdielingsgebonden aktiviteiten complementair aan de bestaande zorgverlening, gericht op de specifieke noden en behoeften van geriatrische patiënten, gecoördineerd door een internist-geriater (Fiolet e.a., 1988,1989). Het feit dat het hier steeds handelt om patiënten die zijn opgenomen in het ziekenhuis, heeft vanzelfsprekend consequenties voor de aard van de problematiek die in deze geriatrische patiëntenpopulatie wordt aangetroffen. Bovendien betekent dit een duidelijk onderscheid tussen het Flankerend Geriatrisch Beleid en de geriatrie in het algemeen, waarvan de klinische geriatrie een onderdeel vormt.

Uitgangspunten voor de formulering van de doelstellingen van het Flankerend Geriatrisch Beleid zijn de volgende:

- Het aantal oudere patiënten, dat valt onder de definitie geriatrische patiënten of dat geriatrische kenmerken vertoont, overtreft vele malen de huidige of de in de nabije toekomst te verwachten capaciteit van de GAAZ'en.

- Naast specifieke geriatrische patiëntenzorg is binnen de ziekenhuisorganisatie in toenemende mate behoefte aan deskundigen, verantwoordelijk voor het algemeen beleid ten aanzien van het snel groeiende aantal oudere patiënten.

- Er bestaat binnen diverse grote specialismen een grote hoeveelheid kennis omtrent ouderenproblematiek, voortkomend uit het gegeven dat een groot gedeelte van het patiëntenbestand bejaard of zelfs hoogbejaard is. Bijvoorbeeld: neurologie, orthopedie en interne geneeskunde.

- De structuur moet toepasbaar zijn op elke willekeurige ziekenhuisafdeling, met uitzondering vanzelfsprekend van zeer gespecialiseerde afdeling; zoals de kinderafdeling en de Intensive Care. 
- Het is gezien de aard van de patiëntenpopulatie wenselijk dat geriatrische zorgverlening zo dicht mogelijk bij de patiënten wordt gebracht. Derhalve dient een structuur te worden ontwikkeld, die toepasbaar is in alle (algemene) ziekenhuizen.

- De geriatrische patiëntenzorg dient aan te sluiten op de bestaande structuur in de gezondheidszorg en niet te leiden tot duplicering of substitutie van bestaande hulpverlening.

- De te ontwikkelen structuur moet flexibel van karakter zijn in die zin, dat geen grote aanpassingen noodzakelijk zijn om de te verwachten toename van het aantal oudere en/of geriatrische patiënten op te vangen.

- De uitkomsten in termen van resultaten van zorg dienen vergelijkbaar of zo mogelijk beter te zijn dan de uitkomsten van zorg in geriatrische afdelingen. - De structuur moet ook toepasbaar zijn in academische ziekenhuizen, zodat een voedingsbodem wordt gecreëerd voor initiatieven op het gebied van fundamenteel en patiëntgebonden wetenschappelijk onderzoek op het gebied van de klinische geriatrie (CBC, 1988).

- De organisatie moet aansluiten bij de huidige strategie om elke gezondheidsregio te voorzien van een GAAZ, zodat in gang zijnde ontwikkelingen op het gebied van geriatrische zorgverlening niet onnodig worden gefrustreerd.

- Gelet op de aard van de geriatrische patiëntenproblematiek moet worden gestreefd naar een model, waarbij multidisciplinaire benadering centraal staat.

De aldus geformuleerde uitgangspunten hebben geleid tot het concept van het Flankerend Geriatrisch Beleid. Kern van dit beleid is het complementaire karakter ten opzichte van de bestaande gezondheidszorgstructuur en het ontbreken van een specifieke afdelingsstructuur. Het Flankerend Geriatrisch Beleid kan worden beschouwd als een vorm van consultatie. Uit de studie van Sears e.a. aangaande consultatie blijkt dat het effect van consultatie negatief wordt beinvloed door het aantal adviezen dat wordt gegeven en de mate van inzet van medische en verpleegkundige aktiviteit die wordt gevraagd (Sears e.a. 1983). Adviezen met betrekking tot medicatie werden in het onderzoek van Sears e.a. het beste opgevolgd.

Voor de uitvoering van het Flankerend Geriatrisch Beleid is een specialist, die deskundigheid heeft verworven op het gebied van de geriatrie verantwoordelijk. In het experiment zoals dit verder wordt beschreven, neemt de discipline Interne Geneeskunde de centrale plaats in. Deze keuze komt voort uit het gegeven, dat de Interne Geneeskunde een langdurige traditie heeft waar het gaat om de behandeling van oudere patiënten. Analyse van de aandoeningen zoals die veelal worden aangetroffen bij geriatrische patiënten, leidt bovendien tot het inzicht dat problematiek op het gebied van de Interne Geneeskunde ook de grootste gemene deler vormt bij een geriatrische populatie. Deze stelling wordt overigens onderbouwd door het gegeven, dat de 
opleiding tot klinisch geriater ook een verplichte vooropleiding Interne Geneeskunde van twee jaar omvat. In België heeft de geriatrie zich ontwikkeld als één van de disciplines binnen het vakgebied van de Interne Geneeskunde. Uit de discussie tussen Belgische en Nederlandse geriaters blijkt echter dat zij hetzelfde vak beoefenen (Hellemans e.a., 1982). Veelzeggend is bovendien dat de Nederlandse pioniers op het gebied van de klinische geriatrie - voor zover specialistisch geschoold - vrijwel zonder uitzondering een internistische achtergrond hebben.

De Fockert (1983) schrijft hierover: "met name ten opzichte van de interne geneeskunde en de verpleeghuisgeneeskunde zijn de randgebieden breed en omvangrijk".

\section{De organisatie van het Flankerend Geriatrisch Beleid (FGB)}

De coördinatie van het Flankerend Geriatrisch Beleid zoals beschreven in dit onderzoek is in handen van de internist-geriater. Aanmeldingen door huisartsen en specialisten worden mondeling, (telefonisch) en/of schriftelijk gedaan. Het kan hierbij zowel gaan om patiënten voor wie de huisarts om opname en evaluatie verzoekt, als om patiënten, die reeds zijn opgenomen in het ziekenhuis en bij wie de behandelend specialist de indicatie voor geriatrische consultatie stelt.

Als de patiënt is verwezen door de huisarts, wordt de patiënt in eerste instantie ontvangen op de polikliniek geriatrie. Is sprake van spoed dan wordt - na overleg - de patiënt verwezen naar de afdeling acute opnames en daar onderzocht. Indien de problematiek dusdanig is dat opname in het ziekenhuis is aangewezen, wordt op grond van de geconstateerde afwijkingen een keuze gemaakt, welk basisspecialisme het meest geschikt is voor behandeling. In overleg met de betreffende specialist wordt vervolgens opname op diens afdeling geregeld.

Deze specialist is de hoofdbehandelaar. Hij is primair verantwoordelijk voor de behandeling van de afwijkingen die tot opname hebben geleid. Bij het eerste contact van de internist-geriater met de patiênt wordt naast de conventionele anamnese en het lichamelijk onderzoek, aandacht besteed aan gegevens omtrent het psychisch en sociaal funktioneren en aan specifiek geriatrische aandachtspunten zoals mictie en defaecatie, zintuiglijk funktioneren, het zelfzorgvermogen, de mobiliteit, het voorkomen van zogenaamde geriatric giants, het sociale netwerk en de betrokkenheid van professionele hulpverleners. Op grond van deze gegevens wordt een onderzoek- en behandelplan geformuleerd, waarin aan bovengenoemde items separaat aandacht wordt besteed. In veel gevallen blijkt het nuttig en zelfs noodzakelijk aanvullende gegevens te vergaren via contact met familie, verzorgers, de huisarts, behandelend specialisten en eventuele andere betrokkenen.

Nadat de problematiek op deze wijze heeft geleid tot het formuleren van doelstellingen, wordt in overleg met de afdelingsspecialist dit verder uitge- 
werkt en vindt onderlinge afstemming plaats. Daarbij wordt contact gelegd met de eventueel benodigde consulenten, paramedische diensten en met de afdeling maatschappelijk werk. Een belangrijk element in dit geheel is voorts de dialoog met de verpleegkundigen van de betreffende afdeling.

Voor patiënten die reeds zijn opgenomen in het ziekenhuis en die worden verwezen door een specialist geldt in essentie dezelfde procedure. Het verschil zit met name daarin dat hierbij gebruik kan worden gemaakt van diagnostische en observationele gegevens die bij behandelend arts en verpleegkundigen reeds aanwezig zijn. Het gevaar van een multidisciplinaire aanpak is het ontbreken van voldoende mogelijkheid tot gestructureerd overleg en het daardoor ontbreken van een gecoördineerde aanpak. Om deze reden wordt wekelijks, naast de individuele contacten die er zijn met afdelingsspecialisten en verpleegkundigen, een multidisciplinaire geriatrische patiëntenbespreking georganiseerd. Psychiater, neuroloog, revalidatie-arts, fysiotherapeuten en bezigheidstherapeuten, maatschappelijk werkenden en afdelingsverpleegkundigen zijn daarbij betrokken. De doelstelling van deze bijeenkomst is niet primair diagnostisch maar heeft het karakter van een coördinerend beraad.

De aldus in het FGB opgenomen patiënten kunnen - zo zal duidelijk zijn - door deze organisatievorm op elke afdeling in het ziekenhuis, met uitzondering van de kinderafdeling, worden aangetroffen. De continuïteit van zorg gedurende de opname wordt gegarandeerd door enerzijds de supervisie van de afdelingsspecialist en anderzijds de dagelijkse visite door de arts van het FGB.

De geformuleerde doelstellingen, voor zover niet direct klachtgericht betreffen:

I. reaktivatie

II. resocialisatie

III. demedicatie

IV. funktionele (her)oriëntatie en

V. continuiteit van zorg.

\section{Reaktivatie}

Het woord reaktivering is afgeleid van het Engelse begrip "active treatment". Het gaat hierbij om het opheffen of verminderen van hulpbehoevendheid in het bijzonder bij bejaarden (v.Proosdij, 1972).

Stoornissen van het houdings- en bewegingsapparaat zijn een veelvuldig voorkomend probleem in de geriatrie (Pinholt, 1987; v. Proosdij, 1977). De mobiliteit wordt bepaald door een complex van intrinsieke en extrensieke faktoren (Sabin, 1982). Naast fysieke handicaps spelen economische en sociale omstandigheden, de beschikbaarheid van hulp en de persoonlijke motivatie een belangrijke rol (Fiolet e.a., 1987; v. Proosdij, 1976; Tinetti, 1986). Daarnaast, al dan niet samenhangend met een beperkte mobiliteit, worden even- 
eens frequent waargenomen stoornissen bij de aktiviteiten van het dagelijks leven (ADL-funkties) en de bijzondere dagelijkse aktiviteiten (BDL-funkties) (Wilcock, 1978). Tesamen met problematiek verbonden aan het verlies van controle over defaecatie en/of mictie leiden deze handicaps ertoe dat het vermogen zich zelfstandig te handhaven in de oorspronkelijke woonsituatie tijdelijk of zelfs voorgoed verloren dreigt te gaan (Ouslander, 1986). Hierbij moet worden bedacht dat deze handicaps niet steeds uitsluitend worden veroorzaakt door somatische problematiek. Deze kunnen ook het resultaat zijn van stoornissen in het psychisch en/of cognitief funktioneren (Cox e.a, 1988; DMB, 1987; Janken e.d., 1986; Tinetti, 1986).

Het lijkt vanzelfsprekend dat ziekenhuisopname leidt tot algemeen herstel, maar de ervaring met het funktioneren van de conventionele ziekenhuiszorg leert dat er een sterke neiging bestaat diagnostiek en behandeling van een specifieke aandoening hoge prioriteit te geven, daarbij voorbijgaand aan het integraal funktioneren van de patiënt (v. Proosdij, 1976).

Uitsluitend door speciaal aandacht te schenken aan hand haven en verbeteren van mobiliteit, zelfzorgvermogen en psychisch funktioneren kan worden voorkomen, dat de ziekte geneest, die aanleiding was voor opname, terwijl de patiënt verslechtert (Tinetti, 1986; Vetel, 1987).

Pragmatisch gesproken betekent dit bijvoorbeeld, dat patiënten zo snel mogelijk moeten worden gemobiliseerd en dat zo mogelijk vanaf de dag van opname middels paramedische begeleiding wordt gewerkt aan de mobiliteit. Dit houdt in dat op het moment van geriatrische consultatie mobiliteit, ADLfunktioneren, beheersing van primaire lichaamsfunkties en psychisch/cognitief funktioneren worden vastgelegd. Onmiddelijk hierop volgend wordt een basisprogramma gestart, waarbij fysiotherapeut, ergotherapeut en/of bezigheidstherapeut een belangrijke rol spelen. Aan de hand van gegevens omtrent het funktioneren in de periode voorafgaand aan de ziekenhuisopname, gecombineerd met de te verwachten handicaps voortvloeiend uit de aanwezige aktieve aandoeningen die hebben geleid tot ziekenhuisopname, wordt in tweede instantie een aanpassing gepleegd, waarbij de doelstellingen van de behandeling nader worden geformuleerd. Uitgangspunt hierbij is dat in elk geval handhaving van het niveau van funktioneren van voor de opname wordt nagestreefd: individueel kan vervolgens de mogelijkheid tot verbetering van dit niveau worden beoordeeld ten aanzien van haalbaarheid en noodzaak (de Vries, 1988). Een belangrijk element hierbij vormen de eisen, die aan de patiënt in zijn oorspronkelijke woonsituatie werden en worden gesteld. Bijvoorbeeld het vermogen zelfstandig de medicatie te gebruiken. Hieraan worden in een zelfstandige woonvorm veel hogere eisen gesteld dan in een verzorgingstehuis.

Het belang van vroegtijdige interventie wordt versterkt door het gegeven dat tijdens de eerste dagen van opname niet zelden een sterke teruggang van mobiliteit en zelfzorgvermogen waarneembaar is. Dit hangt samen met het ontbreken van onvoldoende inzicht in de noodzaak daartoe bij het conventio- 
neel medisch handelen. Illustratief hiervoor is dat decubitus en contractuurvorming veelal reeds kort na opname optreden (Reuler e.a., 1981).

\section{Resocialisatie}

Het vermogen zich te handhaven in de oorspronkelijke woonsituatie wordt niet alleen bepaald door funktionele aspecten als mobiliteit en zelfzorgvermogen, maar eveneens door de mate waarin een patiënt onderdeel uitmaakt van een sociaal netwerk (Mann, 1986). Met name achteruitgang in het psychisch en/of cognitief funktioneren leidt gemakkelijk tot isolement en tot het wegvallen van noodzakelijke maatschappelijke ondersteuning. Ook in het ziekenhuis is een dergelijk proces waarneembaar (Young, 1989). Verwarde en onrustige patiënten worden bij voorkeur geïsoleerd. Deze afzondering leidt tot een verlaging van het aantal positieve prikkels uit de omgeving, sociale. controle ontbreekt, positieve "reinforcement" gaat verloren en een voortgaande deterioratie van het funktioneren is het gevolg. Bij het bestrijden van isolatie in het ziekenhuis ontstaat een conflictsituatie waarbij voortdurend het belang van de individuele patiënt moet worden afgewogen tegen het belang van de overige patiënten op een bepaalde afdeling. Verpleging en medische staf zijn frequent sterk afwerend in hun reaktie wanneer het erom gaat onrustige, verwarde patiënten terug te plaatsen naar een meerpersoonskamer. Dit is ook nog het geval wanneer de patiënt in kwestie de verschijnselen van verwardheid en onrust, die aanleiding vormden tot isolatie, reeds geruime tijd niet meer toont. Het consequent streven naar opheffen van een dergelijk isolement leidt verrassend genoeg slechts zelden tot grote problemen mits de nodige omzichtigheid wordt betracht. Ondersteunende medicamenteuze maatregelen kunnen soms uitkomst bieden.

Sociale isolering, voorafgaande aan opname in het ziekenhuis, een eveneens veel voorkomend probleem, kan de directe aanleiding voor opname vormen en kan bij het bepalen van de ontslagrichting van doorslaggevende betekenis zijn. Zeker wanneer het gaat om alleenwonende hoogbejaarde patiënten zal dit een motief zijn te bezien of plaatsing in een verzorgingstehuis tot de mogelijkheden behoort. Hierop wordt teruggekomen bij het onderwerp "continuïteit van zorg".

Inschakeling van aktiviteitentherapie, niet als tijdverdrijf maar naar de letter als therapie, kan een goede oplossing zijn. De in veel ziekenhuizen waarneembare trend wellfare-afdelingen eenvoudig op te heffen, moet vanuit deze optiek als ongewenst worden beschouwd. Het omvormen van een wellfareafdeling tot een therapeutische werkplaats verdient met het oog op de isolatieproblematiek nadrukkelijk overweging. Door stelselmatige aktiviteiten en contacten te bevorderen zal ook een positief effect worden bereikt op de veel voorkomende stoornissen in het dag-nachtritme en de evenzo vaak voorkomende in- en doorslaapstoornissen. 


\section{Demedicatie}

Ouderen gebruiken vaak teveel, de verkeerde, onjuist gedoseerde of zelfs geheel overbodige medicijnen. Het systematisch en herhaald heroverwegen van de toegediende medicatie is om meer redenen een dankbare taak. Het aantal te verwachten bijwerkingen neemt in het algemeen recht evenredig toe met het aantal gebruikte medicijnen. Een toegenomen halfwaardetijd (zoals voor de meeste medicijnen bij ouderen geldt), een afname van het aantal receptoren, een verminderde reserve op orgaanniveau en een verhoogd risico op foutieve inname, zijn slechts enkele argumenten die hierbij van belang zijn (Koch-Weser e.a., 1982, 1983; Busse e.a., 1983; Gosney e.a., 1984; Bayer e.a., 1985; Raskind, 1986). Veel van de bekende geriatrische "topics", zoals verwardheid, recidiverend vallen, onrust en dehydratie zijn terug te voeren op overdadig medicijngebruik. Ook wanneer de doelstellingen van een therapie niet worden afgestemd op de specifieke omstandigheden van ouderen, zal het middel erger worden dan de kwaal. Een voorbeeld is de bloedsuikerregulatie met bloedsuikerverlagende middelen. Indien bij een hoogbejaarde dezelfde "scherpe" bloedsuikerwaarden worden nagestreefd als bij jeugdiger personen, vormt het optreden van langdurige hypoglycaemieën een complicatie waarvan de gevolgen de consequenties van diabetische orgaanschade ver overtreffen.

\section{Funktionele heroriëntatie}

De beperkte levensverwachting waarvan sprake is bij veel in het ziekenhuis opgenomen geriatrische patiënten, de aanwezigheid van niet behandelbare of te genezen aandoeningen, de bestaande irreversibele funktionele handicaps en de beperkte belastbaarheid zijn, zowel op zichzelf als in combinatie, argumenten om bij de planning van diagnostiek en therapie in sterke mate het aspect funktionaliteit te laten meewegen.

Als voorbeeld kan worden gewezen op het belang van meer of minder uitgebreide diagnostiek bij patiënten met een dementiesyndroom. Dergelijke diagnostiek heeft voor een 80 -jarige patiënt met snel progressieve achteruitgang in het cognitief funktioneren met een abrupt begin en focale uitvalsverschijnselen een andere dimensie dan voor een 80 -jarige bij wie sprake is van langdurige geleidelijke achteruitgang in het cognitief funktioneren die wordt opgenomen in een terminale fase ten gevolge van uitgebreide levermetastasering. Hoewel dit voorbeeld extreem is komt hieruit naar voren dat het niet uitsluitend de leeftijd als zodanig en evenmin de aanwezigheid van éen specifieke aandoening - i.c. een dementiesyndroom - is die de doorslag geeft. Met nadruk wordt gesteld dat dergelijke overwegingen alle aspecten van het handelen kunnen betreffen.

Een veel voorkomend dilemma in de kliniek van geriatrische patiënten is bijvoorbeeld het al dan niet gebruiken van voedingssondes. 
Dit gebruik is zeker bij patiënten met een vergevorderd dementiesyndroom een gevoelige zaak. Bij tijdelijke voedingsproblemen, bijvoorbeeld door een intercurrente luchtweginfektie, kan een dergelijke maatregel goede resultaten opleveren en voor iedereen acceptabel zijn. Bij langdurig gebruik moet de aard van het onderliggende lijden, de kwaliteit van leven en de reaktie van de patiënt op een dergelijke maatregel, zwaar meewegen in het besluit de therapie al dan niet te initiëren of te continueren (Lo e.a., 1984; Wanzer e.a., 1984). Bij het bepalen van wat funktioneel is voor de patiënt in kwestie gaat het zeker niet altijd om het achterwege laten van bepaalde handelingen. Ook bij een patiënt met een zeer beperkte levensverwachting kan de ontdekking van een mammacarcinoom aanleiding zijn tot het verrichten van een lumpectomie of zelfs uitgebreidere excisie, bijvoorbeeld omdat pijnklachten of ulceraties op deze wijze het beste kunnen worden behandeld en dus de kwaliteit van het resterend leven positief kan worden benvloed.

De keuze tussen "cure" en "care" kan, voor zover deze speelruimte nog reëel aanwezig is, eveneens onderdeel uitmaken van een dergelijk beleid.

Door zo het handelen te encadreren zal het beleid in medisch en verpleegkundig opzicht bij plotselinge verandering in de klinische toestand van de patiënt ook gemakkelijker bij te stellen zijn "Acute handelingen", die, gezien de situatie waarin de patiënt verkeert, beter achterwege blijven, kunnen zo worden vermeden.

\section{Continuiteit van zorg}

De multiple pathologie, het veelvuldig voorkomen van chronische aandoeningen, het labiele evenwicht en de (dreiging van) chronische hulpbehoevendheid veroorzaken dat voor geriatrische patiënten sterker dan voor niet-geriatrische geldt dat het beleid erop moet zijn gericht niet uitsluitend aandacht te schenken aan diagnostiek, therapie en funktieverbetering gedurende de opname, maar dat evenzeer aandacht moet worden gegeven aan de situatie na ontslag uit het ziekenhuis (Keirse, 1981). Hierbij spelen intensieve contacten met de eerste lijn, waaronder huisarts, gezinszorg, wijkverpleging, en mogelijk mantelzorgers een belangrijke rol (Jaspers, 1990).

Een belangrijke plaats in de zogenaamde mantelzorg is toebedeeld aan de kinderen. Wat dat betreft ziet de toekomst er zorgelijk uit. Momenteel heeft $10 \%$ van de bejaarden geen kinderen. Rond het jaar 2000 zal dit percentage naar schatting $25 \%$ bedragen (Kruit, 1988). In hoeverre aanwezige kinderen voor hun ouders willen of kunnen zorgen hangt verder natuuriijk in sterke mate af van aspecten als woonsituatie, onderlinge relatie, beschikbare tijd, financiële en/of ruimtelijke mogelijkheden (Lawton e.a., 1984; Nuy e.a, 1985). In het algemeen lijken de huidige maatschappelijke ontwikkelingen niet gunstig voor het aandeel dat kinderen kunnen of willen hebben in deze zorgverlening. Maatschappelijke dienstverlening in andere kaders kan dit wellicht compenseren (Flendrig e.a., 1988). 
Het effect van aanvullende zorg tijdens de eerste weken na ontslag uit het ziekenhuis voor patiënten ouder dan 75 jaar is onderzocht door Townsend e.a. (1985). Zij vonden een significante reductie in het aantal heropnames in de daaropvolgende 18 maanden ten opzichte van patiënten die deze aanvullende zorg niet kregen. Overigens lag voor beide groepen het percentage heropnames in de eerste 3 maanden na ontslag betrekkelijk hoog ( $23 \%$ in beide groepen).

De aandacht voor continuiteit van zorg heeft ook consequenties voor het bepalen van het ogenblik van ontslag. Dit moment wordt niet alleen bepaald door het feit dat diagnostiek en behandeling zijn afgerond c.q. poliklinisch kunnen worden gecontinueerd, maar tevens door het gegeven of ja dan nee de zorg in de woonsituatie dusdanig is geregeld dat redelijkerwijs een voldoende zekere basis bestaat voor handhaving van het bereikte funktioneringsniveau. Verlenging van de opname die om deze reden nogal eens ontstaat, moet nadrukkelijk worden besproken met de leden van het behandelteam, omdat dit aspect niet steeds door ieder van hen vanzelfsprekend en voldoende in de besluitvorming wordt meegenomen.

Het organiseren van zorgverlening na ontslag is niet altijd eenvoudig. Door beperkte menskracht bij Gezinszorg en Kruisvereniging is zorgvuldige planning in een zo vroeg mogelijk stadium gewenst. Dit heeft als consequentie dat zo vroeg mogelijk tijdens de opname aandacht moet worden geschonken aan regelingen en voorzieningen noodzakelijk bij ontslag. Het zal onvermijdelijk zijn in een aantal gevallen de oorspronkelijke planning van de datum van ontslag of de ontslagrichting bij te stellen op grond van bepaalde ontwikkelingen in het verloop van de opname. De inspanning en tijd die hiermee zijn gemoeid kunnen echter worden "terugverdiend" door de reductie die bereikt wordt in het aantal heropnames (Besdine, 1983).

Bij de besluitvorming rond plaatsing in een verpleeghuis speelt de wens van de patiënt de voornaamste rol (Robertson, 1983). Als de patiënt niet langer wilsmachtig is kan worden getracht via familie en vrienden zijn eerder geuite voorkeuren te achterhalen. Een belangrijke vraag is voorts wie er gediend is met plaatsing in het verpleeghuis: de patiënt, de overbelaste familie, de behandelend arts en/of het ziekenhuis? (Lo e.a., 1984; de Meier, 1986). Hierbij moeten ook de alternatieve mogelijkheden worden geëvalueerd zoals aanvullende hulpverlening in de oorspronkelijke woonsituatie, dagtherapie of plaatsing in een verzorgingstehuis. Vaak zijn de alternatieven ontoereikend en zal, alles overwegende, toch plaatsing in een verpleeghuis de beste oplossing blijken.

Het groeiend aantal patiënten dat in deze situatie verkeert, vraagt om politieke heroverweging van de middelen die ter beschikking worden gesteld voor zorg in de thuissituatie en een hernieuwde planning van het aantal beschikbare verpleeghuisbedden. 


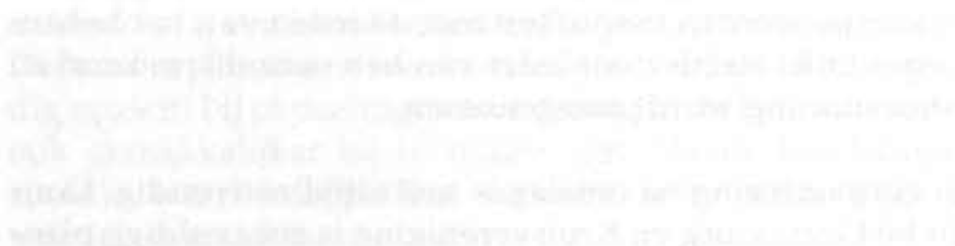

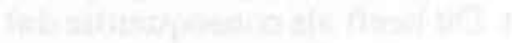

3.

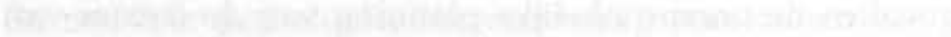
a

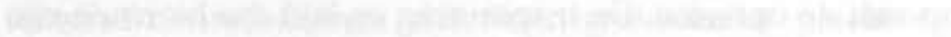

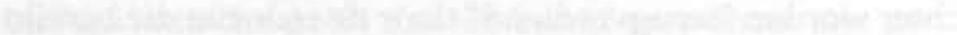

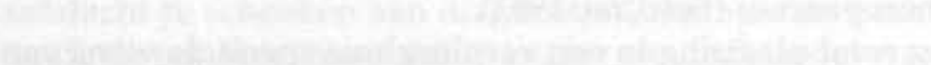




\section{Het onderzoek}

\subsection{De onderzoekspopulatie}

Het primaire verzorgingsgebied van het Academisch Ziekenhuis Maastricht omvat een populatie van 200.000 inwoners in wat wordt genoemd de regio zuidelijk Zuid-Limburg. Ongeveer 25.000 inwoners zijn ouder dan 65 jaar $(12.4 \%)$, hetgeen vrijwel overeenkomt met het landelijk percentage 65-plussers. Omdat het Academisch Ziekenhuis Maastricht het enige ziekenhuis in deze regio is, is het aantal inwoners dat - voor de reguliere gezondheidszorgaktiviteiten - gebruik maakt van ziekenhuisfaciliteiten buiten het academisch ziekenhuis zeer beperkt. Dit schept de mogelijkheid om op relatief eenvoudige en nauwkeurige wijze na te gaan hoeveel en hoe vaak mensen gebruik maken van voorzieningen in de tweede lijn.

Voor het onderhavige onderzoek is gebruik gemaakt van de gegevens van alle geriatrische patiënten, die gedurende hun verblijf in het ziekenhuis zijn behandeld volgens de uitgangspunten van het Flankerend Geriatrisch Beleid. In het totaal 1122 opnames van 987 patiënten. De selectie van deze patiënten heeft in de periode oktober 1988 tot januari 1991 plaatsgevonden. Er kunnen twee subgroepen worden onderscheiden.

De eerste groep bestaat uit geriatrische patiënten, die opgenomen zijn in het ziekenhuis, nadat de verwijzer - doorgaans de huisarts of een medewerker van de SPGD - primair overleg heeft gevoerd met de coördinator van het Flankerend Geriatrisch Beleid. Hierbij gaat het om patiënten, die op basis van dit overleg rechtstreeks zijn opgenomen, veelal via de afdeling Eerste Hulp, ofwel om patiënten die aanvankelijk poliklinisch zijn onderzocht, maar bij wie op grond van de gedane bevindingen eerst in tweede instantie werd besloten tot opname. Opname van deze patiënten resulteerde steeds in de situatie dat - afhankelijk van de problematiek die aanleiding vormde tot het besluit tot opname - door de coördinator overleg werd gepleegd met de betreffende specialist en dat de patiënt vervolgens op diens afdeling werd opgenomen, waarna verdere behandeling in samenwerking met deze specialist werd gerealiseerd.

Een tweede groep wordt gevormd door de patiënten, die al opgenomen waren in het ziekenhuis en voor wie - op grond van de bevindingen van de behandelend specialist - gedurende opname overleg plaatsgevonden heeft 
met de coördinator van het Flankerend Geriatrisch Beleid, hetgeen dan uiteindelijk resulteerde in medebehandeling.

Ongeacht de wijze waarop de verwijzing heeft plaatsgevonden, handelt het hierbij steeds om geriatrische patiënten, oudere patiënten met multiple pathologie, bij wie geriatrische (mede-) behandeling vanaf het eerste overleg met de coördinator plaats heeft gevonden tot het moment van ontslag uit het ziekenhuis.

Niet opgenomen in de studie zijn patiënten jonger dan 55 jaar, patiënten bij wie slechts één "aktief" medisch probleem bestond, patiënten die in de terminale fase van hun ziekte(s) verkeerden, en patiënten bij wie de consultatievraagstelling beperkt was tot één specifiek aspect van zorg (zoals bijvoorbeeld het realiseren van verpleeghuisopname). Onder een "aktief" probleem wordt in dit verband verstaan een probleem waarvoor gedurende de betreffende opname nadere diagnostiek en/of behandeling noodzakelijk is geweest.

Het interval tussen opname in het ziekenhuis en het moment van geriatrische consultatie bedraagt gemiddeld 3 dagen. Bij $66 \%$ van de patiënten heeft geriatrische consultatie plaatsgevonden binnen 48 uur na opname.

Uit het voorafgaande blijkt dat voor alle patiënten geldt, dat in eerste instantie een andere hulpverlener dan de coördinator van het FGB meer of minder doelgericht heeft besloten tot de noodzaak van geriatrische medebehandeling. De belangrijkste verwijzers zijn huisartsen, specialisten, verpleeghuisartsen en medewerkers van de SPGD. Pas daarna heeft selectie - ten behoeve van het onderzoek - plaats gevonden door de coördinator van het FGB. Dit betekent enerzijds dat niet alle geriatrische patiënten, die in de onderzoeksperiode opgenomen zijn geweest in het ziekenhuis, ook in het onderzoek zijn terecht gekomen en anderzijds dat niet alle patiënten die besproken zijn met de coördinator van het FGB ook daadwerkelijk zijn opgenomen.

Vanzelfsprekend kan de vraag gesteld worden hoe nu precies het onderscheid gemaakt is bij de beslissing of al dan niet sprake was van geriatrische problematiek. De definitie van een geriatrische patiënt laat immers veel ruimte voor eigen interpretatie. Waar het extremen betreft is de keuze eenvoudig. Zo zal een patiënt van dertig jaar of jonger nooit gerekend worden tot de categorie geriatrische patiënten, terwijl aan de andere kant een alleenwonende 90-jarige patiënt met diabetes mellitus, een dementiesyndroom, CARA en mobiliteitsstoornissen, die opgenomen wordt in het ziekenhuis vanwege een heupfraktuur, ongetwijfeld een geriatrische patiënt is. Daar tussen in bevindt zich een groot grijs gebied, waarbij de verschillende elementen uit de definitie van een geriatrische patiënt wel enig houvast bieden ('multiple pathologie", 'dreigende blijvende hulpbehoevendheid', 'complexe problematiek', etc.), maar het bij iedere individuele patiënt een afweging van faktoren is die er uiteindelijk toe heeft geleid de bestaande problematiek al dan niet als geriatrisch te bestempelen. Feit is dat hierover bij de in het onderzoek opgenomen 
patiënten in ieder geval steeds consensus bestond tussen verscheidene behandelaars en/of verwijzers. Gezien de verdere bevindingen bij de onderzochte patiëntenpopulatie, zoals in de diverse hoofdstukken beschreven, lijdt het daarbij geen twijfel dat het steeds handelt om een groep patiënten waarbij in sterke mate sprake is van verzorgingsbehoefte, handicapvorming en multiple aandoeningen.

Het probleem van de definitie van wat nu precies een geriatrische patiënt is, blijft uiteindelijk bestaan. In de gememoreerde studies zoals die van Rubenstein e.a. (1984) heeft deze problematiek ook een duidelijke rol gespeeld. Bij zorgvuldige analyse van dergelijk patiëntenmateriaal blijkt uiteindelijk alleen de hoge leeftijd een min of meer constant selectiegegeven.

Dat het bij de onderzochte populatie niet gaat om patiënten die om specifieke -academische- redenen verwezen zijn, mag blijken uit het feit dat $98 \%$ van de patiënten afkomstig is uit het directe verzorgingsgebied van het ziekenhuis, terwijl geen enkele patiënt opgenomen is in de studie die overgeplaatst is vanuit een ander ziekenhuis buiten de regio.

Uitgaande van het gegeven dat in de regio 25.000 personen ouder dan 65 jaar woonachtig zijn en dat veelal verondersteld wordt dat naar schatting $5 \%$ van de bevolking boven de 65 jaar dusdanig problematiek kent dat gesproken mag worden van geriatrische patiënten, betekent dit dat het verzorgingsgebied van het AZM ongeveer 1250 geriatrische patiënten omvat, waarvan een deel opgenomen is in de aanwezige verpleeghuizen. Hoe groot dit deel exact is valt moeilijk na te gaan, maar gezien de omvang van het aantal psychogeriatrische bedden alleen al moet dit aantal tenminste 250 bedragen. Zelfs indien alle overige geriatrische patiënten in de periode van het onderzoek opgenomen zijn geweest in het ziekenhuis, hetgeen hoogst onwaarschijnlijk is, leert een eenvoudige rekensom dat $50 \%$ van deze patiënten ook daadwerkelijk in aanraking komt met het Flankerend Geriatrisch Beleid als 500 à 600 patiënten per jaar worden gezien. In werkelijkheid moet - met inachtneming van de eerder gedane veronderstellingen - dit percentage nog aanzienlijk hoger gelegen hebben. Dit betekent dat de gegevens van de onderzoekspopulatie in redelijke mate representatief geacht mogen worden voor wat er speelt aan klinisch geriatrische problematiek in de betreffende regio. Tevens geeft dit aan dat zowel in termen van bereik als in termen van capaciteit de gehanteerde behandelingsstrategie met de gegeven inzet van mankracht en middelen redelijk toereikend is geweest. Dit laatste heeft vanzelfsprekend implicaties voor de eventuele programmering van soortgelijke aktiviteiten elders, zonder dat hieruit geconcludeerd mag worden dat vergelijkbare uitkomsten zonder meer verwacht kunnen worden.

\subsection{De situatie tijdens opname}

Zoals beschreven zijn de onderzochte patiënten op verschillende wijzen in het ziekenhuis terecht gekomen, aangemeld voor geriatrische evaluatie en opge- 
nomen in het onderzoek. Voor alle patiënten geldt dat één of meer acute dan wel subacute (intercurrente) aandoeningen uiteindelijk hebben geleid tot het besluit tot opname. Bij de keuze van de afdeling en/of het specialisme waar de patiënten werden opgenomen, heeft de opname-indicatie de doorslaggevende rol gespeeld en niet de al dan niet onderkende aanwezigheid van geriatrische problematiek. Het azM heeft geen aparte geriatrische afdeling. Eén van de uitgangspunten van het FGB is dat patiënten niet geconcentreerd worden op één specifieke afdeling, maar op elke willekeurige afdeling van het ziekenhuis in medebehandeling kunnen worden genomen. Dit leidt tot een relatief sterke spreiding van de geriatrische patiëntenzorg in het ziekenhuis. Deze spreiding is echter niet zonder meer evenredig. Afhankelijk van de aard van het specialisme dat er gehuisvest is, hebben afdelingen in meer of mindere mate te maken met geriatrische patiënten. Zo blijkt een aanzienlijk deel van de patiënten opgenomen geweest te zijn op de interne afdeling, terwijl slechts een enkeling behandeld is op bijvoorbeeld de afdeling gynaecologie. Op zich is dit een voor de hand liggende zaak. Uit landelijke gegevens van het SIG betreffende de opnames in ziekenhuizen van patiënten van 65 jaar en ouder in het jaar van het onderzoek 1988 komt dan ook naar voren dat bijna $50 \%$ van alle patiënten ouder dan 65 jaar die opgenomen zijn geweest in dat jaar, behandeld zijn door een vijftal specialismen te weten: interne geneeskunde, cardiologie, pulmonologie, reumatologie en gastro-enterologie. Twee faktoren kunnen van doorslaggevend belang zijn bij de verdere verdeling van de onderzochte patiënten over de diverse afdelingen. Ten eerste het feit dat het niet gaat om ouderen in het algemeen, maar om geriatrische patiënten. De gemiddelde leeftijd ligt derhalve beduidend hoger evenals het aandeel van chronische aandoeningen. Een tweede faktor - met name geldend voor patiënten die na vooroverleg met de coördinator van het FGB (een internist) zijn opgenomen - is dat door de aanwezigheid van multiple pathologie de kans op het eveneens aanwezig zijn (en onderkend worden) van substantiële internistische pathologie relatief hoog is. Dit heeft ertoe geleid dat verhoudingsgewijs veel patiënten opgenomen zijn geweest op de interne afdeling. Het is voorstelbaar dat in een situatie waarin bijvoorbeeld een neuroloog coördinator van het FGB zou zijn met name het aandeel van de afdeling neurologie groter zou zijn. Men zou kunnen denken dat eenzelfde soort redenering er ook toe kan leiden dat de uiteindelijke indeling in diagnosegroepen op deze wijze belangrijke verschuivingen zou kunnen ondergaan. De intensieve betrokkenheid van tal van overige specialisten - naast de coördinator van het FGB blijkend uit de diversiteit van consulenten, ook op individueel niveau, maakt dit laatste echter veel minder waarschijnlijk.

Naast de spreiding van patiënten over de diverse specialismen is in de onderhavige onderzoekssituatie nog een ander element van belang, samenhangend met de situatie op de afdeling interne geneeskunde. Deze afdeling was gehuisvest binnen vijf afzonderlijke verpleegafdelingen, waarvan er vier 
gekenmerkt worden door de aanwezigheid van een specifiek deelspecialisme, te weten endocrinologie, gastro-enterologie, nefrologie en hemato-oncologie. De vijfcle afdeling was ten tijde van het onderzoek ingericht voor zogenaamde 'klasse-patiënten'. Iedere verpleegafdelingen wordt beheerd door een afzonderlijk team van internisten, waarbij in de gegeven situatie de internist-coördinator van het Flankerend Geriatrisch Beleid tevens de internist-supervisor was van de 'klasseafdeling'. Voor zover er op een gegeven moment plaats was betekende dit dat bij een geriatrische patiënt voor wie tot opname werd besloten op een interne afdeling de verzekeringsvorm bepaald heeft of de patiënt in aanmerking kwam opgenomen te worden op deze afdeling. In die situatie is de betreffende patiënt niet alleen wat betreft zijn of haar geriatrische problematiek, maar tevens voor de aanwezige interne problematiek door de coördinator behandeld. Met nadruk wordt gesteld dat deze afdeling verder normaal funktioneerde als interne afdeling en geen GAAZ-afdeling was, noch wat betreft patiëntenpopulatie, noch wat betreft inrichtingsstructuur. De systernatiek van het FGB berust, zoals eerder beschreven op medebehandeling.

\subsection{De relatie tussen 'gewone oudere patiënt' in het ziekenhuis en de onderzoekspopulatie}

Zoals reeds gememoreerd is niet iedere oudere patiënt, die opgenomen wordt in het ziekenhuis, een geriatrische patiënt. Immers, ook voor veel oudere patiënten geldt dat zij in het ziekenhuis terecht komen ten gevolge van betrekkelijk eenvoudige problematiek, zoals een fraktuur, galblaaslijden, een exacerbatie van een reeds langer bestaande CARA e.d., zonder dat sprake is van een labiel evenwicht of een reëel verhoogd risico op het ontstaan en/of toenemen van zorgbehoefte. Zoals al eerder gesteld, omvat de geriatrische patiëntenpopulatie naar schatting slechts $5 \%$ van de bevolking boven de 65 jaar. Wanneer uitsluitend gekeken wordt naar 65-plussers, waarvoor opname in het ziekenhuis noodzakelijk blijkt, zal door de aldus gemaakte voor-selectie het percentage geriatrische patiënten aanzienlijk hoger liggen. Het is echter uitermate onwaarschijnlijk, dat de bijna 20.000 patiënten ouder dan 65 jaar, die in de periode van onderzoek opgenomen zijn geweest in het betreffende ziekenhuis, allemaal tot de categorie geriatrische patiënten hebben behoord, mede op grond van het eerder gememoreerde cijfermateriaal met betrekking tot het aantal geriatrische patiënten dat aanwezig is in het verzorgingsgebied van het AZM.

Een vergelijking tussen een willekeurige groep oudere patiënten, uitsluitend gematched naar leeftijd en geslacht, en de onderzoekspopulatie is om een aantal redenen interessant.

Door vergelijking met een dergelijke aselecte groep - waaronder statistisch gezien onvermijdelijk ook enkele geriatrische patiënten - kan blijken in hoeverre de onderzochte geriatrische patiëntenpopulatie ook daadwerkelijk verschilt van 'gewone ouderen' in het ziekenhuis. 
Wanneer immers verschillen gevonden worden - en zeker wanneer die verschillen erop wijzen dat de gemiddelde patiënt in de onderzoekspopulatie meer hulpbehoevend en gehandicapt is dan de patiënten uit de groep 'gewone ouderen' - vormt dit een belangrijk argument bij de discussie over de mate waarin middels FGB specifiek geriatrische patiënten zijn geselecteerd. Daarnaast kunnen de gevonden verschillen bijdragen aan de operationalisering en precisering van het begrip 'geriatrische patiënt'.

Terecht kan opgemerkt worden dat het een bezwaar is dat, in de groep "gewone bejaarden" waarmee de geriatrische patiënten vergeleken worden, eveneens geriatrische patiënten voorkomen, waardoor de gevonden overeenkomsten en/of verschillen worden beïnvloed. Daar staat dan echter tegenover dat juist door de vergelijking zo te maken de waarde van de gegevens ook een extra dimensie krijgt. Bij het praten over de problematiek van de vergrijzing in relatie tot de gezondheidszorg wordt immers veelal gebruik gemaakt van feiten en cijfermateriaal, gebaseerd op de totale ouderenpopulatie, waaronder eveneens de geriatrische patiënten. Voor zover de gezondheidszorg is aangepast aan de specifieke noden en behoeften is uitgegaan van deze in feite gemengde populatie. Door nu de onderzoekspopulatie geriatrische patiënten te vergelijken met een dergelijke gemengde populatie, ontstaat een helder beeld van de mate waarin geriatrische patiënten verschillen van de gemiddelde oudere patiënt. Zou in de vergelijkingsgroep gestreefd zijn naar het weglaten van de geriatrische patiënten, dan wordt een vergelijking gemaakt met een deelpopulatie van ouderen, namelijk de niet-geriatrische patiënten. Zelfs kan bijeen dergelijke strategie de vraag worden gesteld waarom niet nog andere groepen patiënten zijn weggelaten uit de vergelijkingsgroep, zoals bijvoorbeeld CARA-patiënten, patiënten die opgenomen zijn voor electieve chirurgie, etc.

Een apart hoofdstuk is gewijd aan de uitkomsten van de aldus gemaakte vergelijking.

\subsection{De vraagstellingen en werkhypothesen}

Uitgangspunt in het concept van het Flankerend Geriatrisch Beleid is dat een deel van de oudere patiënten die opgenomen worden in het ziekenhuis naast orgaanspecialistische zorg samenhangend met hun opname-indicatie behoefte hebben aan aanvullende expertise en behandeling op grond van het feit dat deze patiënten tot de categorie geriatrische patiënten behoren. Bij de verdere vormgeving van het $F G B$ is daarnaast uitgegaan van de veronderstelling dat het mogelijk is deze aanvullende zorg te realiseren zonder hiervoor een specifieke afdeling te realiseren en zonder dat de behandeling in zijn geheel wordt overgenomen: het gaat om het geven van een behandeling complementair aan de reeds bestaande aktiviteiten rondom de patiënt. Inhoudelijk gaat het hierbij enerzijds om het - voor zover nodig - verder analyseren van de gezondheidstoestand van de betreffende patiënt, ten dele vergelijkbaar met 
de wijze waarop algemeen periodiek geneeskundig onderzoek plaatsvindt en anderzijds het vaststellen van de beperkingen, handicaps en verzorgingsbehoefte, al dan niet permanent aanwezig. Een belangrijke overweging hierbij is voorts de gedachte dat het funktieverlies, dat waargenomen kan worden bij veel oudere patiënten opgenomen in het ziekenhuis, mits dit tijdig onderkend wordt en gericht wordt bestreden, in belangrijke mate kan worden teniet gedaan, dan wel worden voorkomen. Deze inspanning op zich kan vertaald worden in meetbare effecten, waaronder niet alleen een herstel van funkties als zodanig, maar onder meer ook bekorting van de opnameduur, een vermindering van het risico van blijvende zorgbehoefte en een toename van de effectiviteit van de opname, gemeten als heropnamefrequentie.

Op basis van de doelstellingen van het FGB zijn een aantal vraagstellingen geformuleerd om het effect ervan te evalueren. Deze vraagstellingen gelden met name de effecten die het FGB heeft op de patiëntencarrière. Gegevens met betrekking tot het funktioneren van het systeem in meer organisatorisch opzicht - alhoewel minstens zo interessant - zijn tijdens deze studie niet systematisch verzameld en vormen derhalve geen onderdeel van de studie.

$\mathrm{Bij}$ het verzamelen en evalueren van de patiëntengegevens is onderscheid gemaakt tussen de gegevens waarmee de patiënt gepresenteerd werd en de gegevens zoals die voorhanden waren op het moment van ontslag.

Deze tweedeling leidt ertoe dat de uiteindelijke uitkomsten tweeledig zijn. Op de eerste plaats ontstaat door de systematische verzameling van een aantal items een beeld van de problematiek van een groep geriatrische patiënten, op het moment van opname in het ziekenhuis. Deze gegevens, die voor een belangrijk deel een statisch karakter hebben, zijn daarom belangrijk omdat ze een nadere invulling geven aan wat verstaan zou kunnen worden onder geriatrische problematiek in kwalitatief en kwantitatief opzicht. Daarnaast kan een deel van deze gegevens beschouwd worden als nulmeting, waarmee de gegevens op het moment van ontslag vergeleken kunnen worden. Dit laatste kan beschouwd worden als een effectmeting van het FGB. Hierbij moeten echter twee feiten niet worden vergeten: ten eerste het in deze situatie niet aanwezig zijn van een controlegroep, wat betekent dat niet het zuivere effect van het FGB, maar het effect van ziekenhuisopname en FGB gemeten wordt. Ten tweede dat faktoren, samenhangend met de onderzoekslocatie en/of de persoon van de onderzoekers, die tevens de uitvoerders waren van het FGB van dusdanige invloed kunnen zijn op de uitkomsten dat de generaliseerbaarheid beperkt is en dat zelfs in vergelijkbare situaties door bovengenoemde oorzaken evaluatie van FGB tot geheel andere uitkomsten zou kunnen leiden. Over het effect van andere faktoren dan het FGB blijkt onzekerheid bestaan, die alleen weggenomen kan worden door in vervolgstudies ofwel op dezelfde locatie andere organisatiemodellen te hanteren, ofwel het FGB elders te evalueren en de uitkomsten ervan te vergelijken met de in deze studie beschreven uitkomsten. 
Meer toegespitst op het uiteindelijke onderzoek zijn de volgende vraagstellingen geformuleerd:

- Wat zijn de persoonsgebonden en sociaal-demografische kenmerken van de geriatrische patiënten in deze studie die behandeld worden volgens de uitgangspunten van het FGB? Het gaat hierbij orn leeftijd, geslacht, burgerlijke staat, woonsituatie, hulpverleningssituatie, medische voorgeschiedenis en de wijze waarop de patiënt uiteindelijk terecht gekomen is in het ziekenhuis.

- Welke ziektebeelden en aandoeningen kunnen worden onderscheiden bij de onderzochte groep patiënten? Deze vraag is van belang om het begrip multiple pathologie nader te evalueren en kan daarnaast gegevens opleveren die indicatief zijn voor de medische samenstelling van het team dat zich in het bijzonder bezighoudt met geriatrische problematiek.

- In welke mate is er sprake van verminderd zelfstandig funktioneren op het moment van eerste consultatie in de onderzochte patiëntengroep. Speciale aandacht wordt hierbij geschonken aan het ADL-funktioneren, de mobiliteit en urine-incontinentie als maat voor de zelfredzaamheid van de patiënt. Deze gegevens zijn tevens bruikbaar, wanneer het gaat om de vraag hoe de verpleegkundige en paramedische begeleiding van dergelijke patiënten kan worden geoptimaliseerd.

- Hoe is het funktioneren van de patiënten op het moment van ontslag? Welke veranderingen kunnen worden waargenomen bij ontslag in relatie tot opname in het ziekenhuis wanneer FGB wordt gerealiseerd? Naast het ADLfunktioneren, de mobiliteit en urine-incontinentie zijn hierbij van belang het overlijdenspercentage/risico, de opnameduur, de uiteindelijke ontslagrichting en de hulpbehoevendheid bij ontslag.

- Wat is de waarde van de Beoordelingsschaal Oudere Patiënten (BOP) en de Gedragsobservatieschaal voor Intramurale Psychogeriatrie (GIP) voor deze patiëntengroep?

Om vanuit deze vraagstellingen te komen tot werkhypotheses, waaraan de uitkomsten van het FGB kunnen worden getoetst, is het noodzakelijk de uitgangspinten van het Flankerend Geriatrisch Beleid nogmaals te formuleren.

- Bij geriatrische patiënten, opgenomen in het ziekenhuis, is naast de primaire opname-indicatie sprake van meervoudige problematiek, leidend tot een verminderd funktioneren in lichamelijk, psychisch en/of sociaal opzicht. Ziekenhuisopname betekent een dusdanige verstoring van het labiele evenwicht, ondanks adequate en effectieve behandeling van de aandoening die heeft geleid tot opname, dat er een verhoogd risico bestaat op verdere achteruitgang in het funktioneren en een toegenomen kans op blijvende zorgbehoefte, waarvoor een intensievere zorgsituatie noodzakelijk is, dan waaruit de patiënt oorspronkelijk afkomstig is. De argumentatie voor deze stelling is in een eerder stadium gegeven. Daarnaast vloeit deze stelling logischerwijs voort uit de eerder gegeven definitie van een geriatrische patiënt. 
- Flankerend Geriatrisch Beleid kan als effectief beschouwd worden, wanneer erdoor bereikt wordt dat bij geriatrische patiënten, opgenomen in het ziekenhuis, het niveau van funktioneren ondanks ziekenhuisopname niet verslechtert of zelfs verbetert, met inachtneming van de gedachte dat de kwaliteit van leven maatgevend is, eerder dan de levensverwachting als zodanig.

Op basis van deze beide stellingen zijn de volgende werkhypotheses geformuleerd:

- Oudere patiënten, die op grond van vermeende geriatrische kenmerken geselecteerd worden voor behandeling in het kader van het FGB verschillen als groep wat betreft diagnoses, funktioneren bij opname, opnameduur, overlijdensrisico en ontslagrichting van de doorsnee oudere patiënt die opgenomen wordit in het ziekenhuis.

- De organisatie van het FGB maakt het mogelijk een groep oudere patiënten in het ziekenhuis te selecteren bij wie aanvullende zorg op medisch, paramedisch en verpleegkundig gebied ertoe leidt dat het funktioneren van deze patiëntenpopulatie tussen opname en ontslag merkbaar verbetert, gemeten aan het ADL-funktioneren, de mobiliteit en de primaire lichaamsfunkties.

In de analyses, die in totaal 987 in het ziekenhuis opgenomen geriatrische patiënten omvatten, zijn bovenstaande hypotheses getoetst.

\subsection{De registratie}

Van alle patiënten die deel uitmaakten van het onderzoek zijn systematisch gegevens verzameld. Alle gegevens zijn verzameld door de personen die direct betrokken zijn geweest bij de uitvoering van het Flankerend Geriatrisch Beleid.

\subsubsection{De registratie bij opname}

A. Persoonsgegevens: leeftijd, geslacht en burgelijke staat

Met het oog op de gegevens analyse is voor de leeftijdsregistratie gebruik gemaakt van een indeling in leeftijdsgroepen van vijf jaar, waarbij acht categoriën onderscheiden zijn, namelijk jonger dan 60 jaar, 61-65 jaar, 66-70 jaar, 71-75 jaar, 76-80 jaar, 81-85 jaar, 86-90 jaar en ouder dan 90 jaar.

Bij de indeling naar burgerlijke staat worden zes categoriën onderscheiden, namelijk:

1) gehuwd (partner in leven)

2) gescheiden (gehuwd geweest, partner al dan niet in leven)

3) ongehuwd (nooit gehuwd geweest)

4) weduwstaat (gehuwd geweest, partner overleden) 
5) samenwonend (niet gehuwd, partner in leven, niet bedoeld worden kinderen en/of verzorgers) en

6) overigen, waarbij de feitelijke situatie onduidelijk of onbekend is.

B. Sociale situatie: woonsituatie, hulpverlening voor opname', geografische afkomst $\mathrm{Bij}$ het benoemen van de woonsituatie is een indeling grehanteerd in zeven categoriën:

1) zelfstandig alleenwonend

2) zelfstandig wonend met partner

3) (in)wonend bij kinderen

4) wonend in een verzorgingstehuis,

5) verblijvend in een somatisch verpleeghuis

6) verblijvend in een psychogeriatrisch verpleeghuis en

7) anderssoortige woonsituatie dan in de voorgaande 6 categoriën.

Bij de indeling in bovenstaande categoriën is uitgegaan van de situatie zoals die officieel (b.v. van gemeentewege) is geregistreerd. Als voorbeeld: een patiënt die bij opname in het ziekenhuis sedert één week officieel verblijft in een verzorgingstehuis is geregistreerd als wonende in een verzorgingstehuis. Een alleenstaande patiënt daarentegen die sedert één week-op tijdelijke basis - verblijft bij de kinderen is geregistreerd als zelfstandig alleenwonend.

De eerste drie - zelfstandig alleenwonend, samenwonend met partner en inwonend bij kinderen - zijn beschouwd als zelfstandige woonvormen. Niet zelfstandige woonvormen zijn wonen in een verzorgingstehuis, verblijf in een somatisch verpleeghuis en verblijf in een psychogeriatrisch verpleeghuis.

Bij geografische herkomst is onderscheid gemaakt tussen patiënten afkomstig uit de gemeente Maastricht, patiënten afkomstig uit de regio zuidelijk ZuidLimburg en patiënten van elders.

Hulpverlening voor opname kent negen categoriën, namelijk

1) geen hulpverlening, d.w.z. geen van de onderscheiden categoriën

2) hulp van familie en/of buren

3) particuliere hulpverlening (bijvoorbeeld schoonmaakhulp)

4) hulpverlening via gezinszorg (inclusief alpha-hulp)

5) gebruik makend van faciliteiten van een dienstencentrum (bijvoorbeeld maaltijdvoorziening)

6) hulpverlening door wijkverpleging

7) in behandeling bij de Sociaal Psychogeriatrische Dienst (SPGD)

8) in behandeling op de polikliniek Geriatrie van het AZM

9) één of meerdere dagen per week dagbehandeling in het verpleeghuis somatisch danwel psychogeriatrisch.

Gezien de verschillende aard van de genoemde categoriën kan een patiënt van meer dan één faciliteit gebruik maken. 
Bij de analyse van de gegevens is hulp van familie en/of buren beschouwd als een vorm van mantelzorg. Voorts is onderscheid gemaakt tussen professionele niet georganiseerde hulpverlening (particuliere hulp), professionele, georganiseerde niet medische hulpverlening (gezinszorg/alpha-hulp, dienstencentrum) en professionele, georganiseerde medische hulpverlening (wijkverpleging, SPGD, polikliniek Geriatrie en dagbehandeling verpleeghuis).

C. Opnamegegevens: spoedopname, heropname, opname-indicatie, ingestelde medische en paramedische therapie, consulten en medebehandelingen, medische diagnoses, zelfzorgvermogen, mobiliteit, mictiepatroon en medicatie.

Onder spoedopnames worden verstaan, die opnames die plaatsvinden binnen 24 uur nadat de betrokken specialist (-en) voor het eerst geconfronteerd is (zijn) met de aandoening of problematiek die geleid heeft tot de opnameindicatie.

Met heropname wordt bedoeld patiënten die in het jaar voorafgaande aan de opname en geriatrische consultatie in het ziekenhuis opgenomen zijn geweest. Daarbij worden drie periodes onderscheiden: minder dan drie maanden tevoren, drie tot zes maanden tevoren en zes tot twaalf maanden tevoren.

Bij het beoordelen van de indicatiestelling op het moment van opname in het ziekenhuis zijn drie, keuzemogelijkheden (somatisch, psychisch/ cognitief en sociaal) die afzonderlijk of in combinatie kunnen voorkomen. Daarbij zijn primaire en secundaire opname-indicaties onderscheiden. Een indicatie is primair als deze op zichzelf opname rechtvaardigt en secundair als de combinatie van bovengenoemde faktoren de opname heeft veroorzaakt. Hoewel subjectief gekleurd, is hierbij een hiërarchische volgorde gehanteerd, waarbij eerst de somatische indicatie is beoordeeld, vervolgens de psychische-cognitieve indicatie en tenslotte de sociale indicatie. Dit betekent dat een patiënt met ernstige dehydratie en een langer bestaand dementiesyndroom een primair somatische indicatie voor opname heeft met een secundaire psychische/cognitieve indicatie. Primair een sociale indicatie betekent dat geen aktieve somatische en/of psychisch/cognitieve problematiek aanwezig is die de opname noodzakelijk maakte, maar dat bijvoorbeeld het wegvallen van essentiële verzorging aanleiding was tot de opname.

Bij de medische therapie zijn afzonderlijk geregistreerd

1) instellen medicatie of veranderen bestaande medicatie

2) parenterale vochttoediening middels een infuussysteem

3) enterale vocht- of voedingsuppletie d.m.v. een maagsonde

4) aanpassen dieet en

5) operatieve ingreep. 
$\mathrm{Bij}$ het registreren van de paramedische therapie is als volgt onderscheid gemaakt:

1) fysiotherapie algemeen

2) fysiotherapie specifiek gericht op ADL-funktioneren

3) ergotherapie

4) logopaedie en

5) aktieve bemoeienis van het maatschappelijk werk in het ziekenhuis.

Bij de registratie van de consulenten en medebehandelaars zijn alle in het ziekenhuis voorkomende specialismen apart onderscheiden. Het onderscheid tussen een consult en een medebehandeling; is niet steeds eenvoudig. Hierbij is aangehouden dat bij problematiek, waarvoor opname noodzakelijk is, maar waarover op inhoudelijke gronden het specialisme van de afdeling waar de patiënt is opgenomen, onvoldoende kennis of kundigheid bezit, aanleiding is te spreken van medebehandeling.

Bij de registratie van consulenten is de aktiviteit van de geriatrische consulent - gezien de doelstellingen van het Flankerend Geriatrisch Beleid - steeds beschouwd als medebehandeling.

De registratie van de medische diagnoses is gebeurd aan de hand van de zogenaamde ICD-classificatie. Hierbij zijn alleen die diagnoses vermeld die een aktief probleem vormden gedurende de periode van het Flankerend Geriatrisch Beleid. Wanneer gesproken wordt over 'dementiesyndroom' zijn hiervoor de criteria gehanteerd van de DSM-III-R, 1987 (Verhey e.a., 1988).

De beoordeling van het zelfzorgvermogen is gebaseerd op de ADL-scorelijst volgens Katz (Katz e.a. 1963,1971).

In engere zin wordt hier eigenlijk de zelfredzaamheid gemeten. Wanneer in het verdere onderzoek over stoornissen in het zelfzorgvermogen wordt gesproken wordt feitelijk dus de mate van stoornis in het ADL-funktioneren bedoeld.

De oorspronkelijke ADL-schaal is ontwikkeld door Katz uit de observaties gedaan bij patiënten met een heupfraktuur. De schaal is gebaseerd op primair biologisch en psychosociaal funktioneren als uiting van de mate waarin neurologische en locomotorische reaktiepatronen adequaat verlopen. De schaal bestaat uit 6 funkties: wassen, kleden, toiletgebruik, transfers, continentie en voedselintake. De patiënt wordt beoordeeld op (on)afhankelijkheid voor deze funkties, waarbij de actuele toestand bepalend is. Uit analyse is gebleken dat (on)afhankelijkheid van toiletgebruik het best de uitkomst van de gehele test voorspelt (Katz e.a. 1963,1971, Spector 1987).

De uitkomsten van deze indeling zijn vervolgens getransformeerd naar een indeling in drie funktionele zorgbehoefteniveau's, namelijk

$A D L=1$ ) voldoende zelfzorgvermogen, geen additionele hulp noodzakelijk $\mathrm{ADL}=2$ ) onvoldoende zelfzorgvermogen, discontinue aanvullende zorg noodzakelijk en 
$\mathrm{ADL}=3$ ) onvoldoende zelfzorgvermogen, continue aanvullende zorg noodzakelijk.

De beoordeling van de mobiliteit heeft plaatsgevonden op basis van een indeling in vijf funktionele categoriër:

1) zelfstandig, geen materiële of personele hulp nodig

2) zelfstandig, wel materiële, geen personele hulp nodig, niet rolstoelafhankelijk

3) afhankelijk van personele hulp, niet rolstoelafhankelijk

4) rolstoelafhankelijk en

5) bedlegerig.

Bij de gegevensanalyse zijn deze gegevens vervolgens getransformeerd naar drie categoriën:

Mobiliteit $=1$ ) geen personele hulp nodig.

Mobiliteit $=2$ ) wel personele hulp nodig.

Mobiliteit $=3$ ) bedlegerig.

Urine-incontinentie, al dan niet aanwezig, is, geregistreerd in vier categoriën:

1) niet of minder dan éénmaal per 24 uur incontinent

2) éénmaal per 24 uur incontinent

3) meer dan éénmaal per 24 uur incontinent en

4) verblijfscatheter, al dan niet naar aanleiding van bestaande urine-incontinentie.

Bij het registreren van de medicatie is gebruik gemaakt van de indeling, zoals gehanteerd in De Nederlandse Pharmacopee. Hierbij zijn alle geneesmiddelen geregistreerd, die door de patiënt gebruikt werden in de 24 uur voor aanvang van de geriatrische consultatie.

D Specifieke beoordelingsinstrumenten.

De Beoordeling voor Oudere Patiënten (BOP).

$\mathrm{Bij}$ het beoordelen van hulpbehoevendheid en gedragsstoornissen is gebruik gemaakt van de Beoordelingsschaal voor Oudere Patiënten. Dit instrument is oorspronkelijk ontwikkeld voor het beoordelen van verpleeghuisbewoners (v.d. Kam e.a., 1971). De zes subschalen waaruit deze vragenlijst bestaat is ingevuld op basis van observatiegegevens door een arts die deel uitmaakte van het geriatrisch behandelteam in overleg met één van de bij de patiënt betrokken verpleegkundigen. De eerste beoordeling heeft plaats gevonden in de tweede week van opname c.q. konsultatie. Verdere uitleg over de inhoud en betekenis van deze schaal wordt gegeven in hoofdstuk 8 . 
De Gedragsobservatieschaal voor de Intramurale Psychogeriatrie (GIP).

Dit meer specifiek op gedragsstoornissen bij ouderen gerichte instrument (Verstraten e.a. 1987) is op overeenkomstige wijze als de BOP-schaal gebruikt. Er zijn 14 subschalen die tot doel hebben meer specifiek dan de BOP schaal en andere beoordelingsschalen voor ouderen specifiek psychogeriatrische gedragsproblemen te beschrijven. Op de inhoud en betekenis van deze schaal wordt eveneens verder ingegaan in hoofdstuk 8 .

N.B. De BOP en de GIP schaal zijn gehanteerd in de periode januari 1990 tot januari 1991. De gegevens hebben dus betrekking op de 407 patiënten die in deze periode zijn opgenomen of heropgenomen en niet zijn overleden.

\subsubsection{De registratie bij ontslag}

A Logistieke gegevens: opnameduur, mortaliteit, ontslagrichting en hulpverlening na ontslag

Bij de opnameduur is geregistreerd de duur van de totale opname. Deze periode is gemiddeld 3 dagen langer dan de duur van de geriatrische medebehandelingsperiode.

Patiënten zijn als overleden geregistreerd wanneer zij overleden zijn in de periode tussen de dag na opname en de dag van ontslag. Patiënten die binnen 24 uur na opname zijn overleden, zijn niet opgenomen in het onderzoek.

Bij de ontslagrichting is dezelfde indeling en systematiek gehanteerd als bij de registratie van verblijfplaats voor opname. Geregistreerd is steeds de feitelijke woon- of verzorgingssituatie direct na ontslag.

Voor hulpverlening na ontslag is de indeling gehanteerd van hulpverlening voor opname.

B Ontslaggegevens: zelfzorgvermogen, mobiliteit, mictiepatroon en medicatie Hierbij is dezelfde systematiek gehanteerd als bij de opnamegegevens.

C Specifieke beoordelingskenmerken

Konform de aanpak bij opname zijn de BOP-en de GIP-scores geregistreerd in de week van ontslag.

\subsubsection{De uitvoering van de registratie}

Zoals reeds vermeld zijn de gegevens verzameld door de personen die deel uitmaakten van het geriatrisch behandelteam. Dataregistratie heeft derhalve niet-geblindeerd plaatsgevonden. Leeftijd, geslacht en geografische herkomst zijn ontleend aan de administratieve bescheiden. De gegevens betreffende 
burgerlijke staat, woonsituatie en hulpverlening voor opname zijn deels gebaseerd op de anamnese en deels op heteroanamnestische informatie van familie en verzorgers.

De indeling in spoedopnames en heropnames is ontleend aan de gegevens van de medische registratie.

De indeling van de opname-indikatie naar somatisch, psychisch/cognitief en/of sociaal is gebaseerd op de interpretatie van de gegevens van de verwijzer (huisarts, medewerker SPGD en/of medisch specialist) in kombinatie met de bevindingen van de medewerker van het geriatrisch behandelteam. Voor registratie van de ingestelde medische en paramedische therapie, de konsulten, medikatie en de medische diagnoses is gebruik gemaakt van het klinisch medisch dossier. De scores betreffende zelfzorgvermogen, mobiliteit en urine-incontinentie zijn verricht door de arts van het geriatrisch behandelteam, gebaseerd op eigen observatie, mededelingen van betrokken verpleegkundigen en gegevens uit het medisch en verpleegkundig dossier. De scores op de BOP en GIP-lijsten hebben plaatsgevonden door de arts van het geriatrisch behandelteam in overleg met de betrokken verpleegkundigen, fysiotherapeuten, aktiviteitenbegeleiders en andere bij de direkte zorg betrokkenen.

Gegevens aangaande de ontslagrichting zijn gebaseerd op de poliklinische follow up van de betrokken patiënten en de gegevens uit het medisch en verpleegkundig dossier. Het betreft hier de feitelijke ontslagrichting en niet de - eventueel afwijkende - geadviseerde ontslagrichting.

Voor een deel van de metingen c.q. de registratie van de onderzoeksgegevens geldt dat het gaat om weinig of niet diskutabele feiten. Interpretatie-effekten spelen geen rol bij het vaststellen van leeftijd, geslacht, woonsituatie voor opname, hulpverlening voor opname, spoedopname, heropname, medische en paramedische therapie, konsulten, medikatie, overlijden en ontslagrichting. Bij het bepalen van de opname-indikatie kan interpretatie van de beschikbare gegevens een probleem vormen. Door de strikt hiërarchische opbouw van dit item, waarbij onderbouwing op basis van gekonstateerde aktieve problemen en diagnoses een belangrijke rol speelt is getracht de objektiviteit zoveel mogelijk te waarborgen. In de beoordelingsschalen voor het ADL-funktioneren, de mobiliteit en de urine-incontinentie is de indeling zodanig gekozen dat de verschillende mogelijkheden elkaar uitsluiten. Voor het ADL-funktioneren en de mobiliteit zijn de uitkomsten vervolgens getransformeerd naar een driedeling om mogelijk nog bestaande overlap verder te elimineren. Bij de beoordeling van aktieve diagnoses heeft validering plaats gevonden door (ter dele retrospektief) na te gaan in hoeverre gegevens betreffende diagnostiek en behandeling hierop te herleiden zijn. Die diagnoses of problemen, waarvoor geen identificeerbare diagnostiek of behandeling heeft plaats gevonden zijn uit de registratie verwijderd.

De diagnose "verzorgingsproblematiek" - die als zodanig niet terug te vinden in de ICD-classificatie - is gebaseerd op het feit dat de opname-indikatie mede 
op sociale gronden is gebaseerd, danwel dat ontslag later plaats gevonden heeft dan mogelijk c.q. gepland op basis van de noodzaak aanvullend (d.w.z. voor opname niet bestaande) professionele zorg te realiseren.

De betrouwbaarheid van de scores op de BOP en de GIP lijsten is verhoogd konform de suggesties van Verstraten e.a. door meer observatoren te betrekken bij het invullen. Uit het onderzoek van Verstraten e.a. (1987) is voorts gebleken dat de interrater-betrouwbaarheid aanvaardbaar is.

\subsubsection{De omvang en samenstelling van de onderzoekspopulatie (zie tabel 3.5.4)}

Tabel 3.5.4 De totale onderzoekspopulatie ingedeeld naar onderzoeksperiode, heropname en overlijden.

\begin{tabular}{|c|c|c|c|}
\hline & le Opname & Heropname & Subtotaal \\
\hline \multicolumn{4}{|l|}{$\begin{array}{l}1 \text { oktober } 1988 \mathrm{t} / \mathrm{m} \\
31 \text { december } 1989\end{array}$} \\
\hline Niet overleden & 489 & 57 & 546 \\
\hline Wel overleden & 85 & 15 & 100 \\
\hline Ssibtotank. & $57 A_{2}$ & 72 & Kak \\
\hline \multicolumn{4}{|l|}{$\begin{array}{l}1 \text { januari } 1990 \mathrm{t} / \mathrm{m} \\
31 \text { december } 1990\end{array}$} \\
\hline Niet overleden & 350 & 57 & 407 \\
\hline Wel overleden & 63 & 6 & 69 \\
\hline Subtotaal & 413 & 63 & 476 \\
\hline Totaal & 987 & 135 & 1122 \\
\hline - aantal opnames & 1122 & & \\
\hline - aantal patiënten & 987 & & \\
\hline - aantal heropnames & 135 & & \\
\hline - aantal overledenen & 169 & & \\
\hline
\end{tabular}

Het onderzoek is uitgevoerd in twee fases. In de periode 1 oktober $1988 \mathrm{t} / \mathrm{m}$ 31 december 1989 zijn van 574 patiënten die aan de criteria voldeden alle genoemde gegevens van 646 opnames geregistreerd met uitzondering van de BOP en de GIP-scores.

Opnames zijn benoemd als eerste opname wanneer de betreffende patiënt niet eerder als geriatrische patiënt behandeld is door het geriatrisch behandelteam. Dit sluit derhalve niet uit dat de patiënt in de voorliggende periode in het ziekenhuis opgenomen is geweest. Van heropname wordt gesproken indien patiënten meer dan énmaal behandeld zijn door het geriatrisch behandelteam in de periode van het onderzoek. 
In de periode 1 januari $1990 \mathrm{t} / \mathrm{m} 31$ december 1990 zijn van 413 patiënten die aan de criteria voldeden 476 opnames geregistreerd. De gegevenverzameling van deze patiënten is overeenkomstig die van de eerder genoemde patiënten; aanvullend zijn van deze patiënten de scores op de BOP- en de GIP-lijsten geregistreerd.

Binnen het totale onderzoeksbestek zijn de gegevens geregistreerd voor 1122 opnames van 987 patiënten, waaronder 135 heropnames. Gedurende het onderzoek zijn tijdens verblijf in het ziekenhuis 169 patiënten overleden. 

than

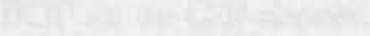




\section{Het verschil tussen de onderzochte geriatrische patiënten en 'gewone ouderen' opgenomen in het ziekenhuis}

\subsection{Inleiding}

De vraag in hoeverre de onderzochte populatie geriatrische patiënten daadwerkelijk verschilt van willekeurige oudere patiënten die in het ziekenhuis worden opgenomen is om meer dan één reden van belang.

Ten eerste wordt door het vinden van verschillen duidelijk gemaakt dat het om een specifieke populatie ouderen gaat. Daarnaast kan analyse van de verschillen tussen 'gewone ouderen' in het ziekenhuis en de onderzochte populatie een bijdrage leveren aan de operationele definiëring van het begrip 'geriatrische patiënt'.

Wanneer in de toekomst door de vergrijzing het aantal geriatrische patiënten in het ziekenhuis toeneemt zal een kwantitatieve analyse van de gegevens tevens een indicatie geven van de verandering in de zorgvraag die dit met zich meebrengt.

Om de verschillen tussen 'gewone ouderen' in het ziekenhuis en de groep onderzochte geriatrische patiënten te kunnen bestuderen is een willekeurige steekproef van 100 geriatrische patiënten uit de onderzochte populatie genomen. Deze patiënten zijn - voor leeftijd en geslacht gematched - vervolgens vergeleken met de gegevens van 100 willekeurig geselekteerde oudere patiënten, die gedurende de periode van het onderzoek in het ziekenhuis werden opgenomen en zijn onderzocht volgens de systematiek van het Flankerend Geriatrisch Beleid.

Voor deze laatste groep patiënten zijn de gegevens bij opname en ontslag geregistreerd op dezelfde wijze als dit gebeurd is bij de geriatrische patiënten. Belangrijk verschil is dat in deze zgn. referentiegroep geen interventie van welke aard dan ook heeft plaatsgevonden door het geriatrisch behandelteam. De opnamespecialist en overige behandelaars van deze patiënten zijn niet geïnformeerd over de aard van de gegevensverzameling of de verkregen uitkomsten. Hierdoor is vermeden dat deze patiënten op zich weer in een 
uitzonderingspositie kwamen te verkeren ten opzichte van andere ouderen opgenomen in het ziekenhuis.

De gegevens van de aldus geselecteerde 200 patiënten zijn statistisch bewerkt nadat is onderzocht in hoeverre de steekproef uit de groep geriatrische patiënten representatief is voor de totale groep geriatrische patiënten.

\subsection{De geriatrische patiënten}

Het totaal aantal geriatrische patiënten waaruit de steekproef is genomen bedraagt 646 . Bij vergelijking tussen de 100 patiënten in de steekproef en de 546 overige patiënten blijkt dat er geen significante verschillen bestaan (zie bijlage I), waarmee in de verdere analyse rekening gehouden dient te worden, met uitzondering van de gemiddelde opnameduur.

De gemiddelde opnameduur bedraagt voor de totale groep 40,5 dagen. Voor de 100 patiënten in de steekproef bedraagt de gemiddelde opnameduur 45,4 dagen. Dit is significant langer dan van de overige geriatrische patiënten: 39,4 dagen (T-test: $p=0,046$ ). Hiervoor is geen duidelijke verklaring.

\subsection{De vergelijking tussen de geriatrische patiënten $(n=100)$ en de referentiepopulatie $(\mathbf{n}=100)$}

Beide groepen zijn gematched voor leeftijd en geslacht. Bij verdere analyse blijken er geen significante verschillen te bestaan voor persoonsgegevens en sociaal demografische gegevens, zoals burgerlijke staat, percentage spoedopnames en woonsituatie voor opname.

\subsubsection{Algemene gegevens}

\subsubsection{Hulpverlening voor opname}

Wanneer beide populaties worden vergeleken ten aanzien van de hulpverleningssituatie voor opname bestaan er significante verschillen in de frequentie waarin hulp ontvangen wordt van familieleden, gezinszorg, wijkverpleging, sociaal psychogeriatrische dienst en dagtherapie van het verpleeghuis (zie tabel 4.3.1.1). Geen significante verschillen worden gevonden voor hulp van UVV of een dienstencentrum.

\subsubsection{Heropnames}

Het percentage patiënten dat in de periode van 12 maanden voorafgaand aan de onderzochte opname eerder in het ziekenhuis opgenomen is geweest is significant verschillend; referentiepopulatie: $27 \%$ versus geriatrische patiënten: $71 \%\left(x^{2}, p<0.000\right)$. 
Tabel 4.3.1.1 Hulpverlening voor opname (percentage)

Vergelijking van de steekproef van referenten $(n=100)$ met de steekproef geriatrische patiènten $(n=100)$ : het percentage patiënten dat gebruik maakt van hulpverlening.

\begin{tabular}{lccl}
\hline Hulpverlening & Referenten & $\begin{array}{l}\text { Geriatrische } \\
\text { patiënten } \\
\mathrm{n}=100\end{array}$ & p-waarde \\
\hline Familie & 17 & 72 & $<0.001$ \\
Gezinszorg & 7 & 44 & $<0.001$ \\
Wijkverpleging & 3 & 16 & $<0.01$ \\
SPGD & 1 & 14 & $<0.01$ \\
Dagtherapie & 0 & 4 & $<0.05$ \\
Totaal & 78 & 150 & \\
\hline
\end{tabular}

$\chi^{2}$ of Fischer Exact Test.

$S P G D=$ Sociaal Psycho-Geriatrische Dienst

\subsubsection{Opname-indicatie}

Wanneer bij opname afzonderlijk de aanwezigheid van een somatisch, psychische, cognitieve en sociale indicatie wordt greëvalueerd blijken er tussen beide groepen significante verschillen te bestaan.

In het merendeel van de gevallen bestaat er een somatische opname-indicatie: $100 \%$ en $92 \%$ voor resp. de referentiepopulatie en de geriatrische patiënten $\left(x^{2}: p<0,01\right)$. Percentueel lopen beide populaties meer uiteen voor de overige indicatie gebieden.

Psychische indicatie

Sociale indicatie
$1 \%$ versus $39 \%\left(x^{2} p<0.000\right)$,

$1 \%$ versus $19 \%\left(x^{2} p<0.001\right)$.

\subsubsection{Consulten}

Het gemiddelde aantal consulenten die gedurende opname betrokken zijn geweest bij beide populaties is significant verschillend, namelijk 0,88 en 2,11 (T-test, $\mathrm{p}<0.000$ ). Deze verschillen worden bepaald door het verschil in aantal consulten van de neuroloog, de psychiater, de uroloog en de revalidatie-arts (zie tabel 4.3.1.4).

\subsubsection{Opnameduur}

De gemiddelde opnameduur van de referentiepopulatie is 21,8 dagen. Voor de geriatrische patiënten 45,4 dagen (T-test, $p=0.0001$ ).

\subsubsection{Overlijden}

In de referentiepopulatie zijn 4 patiënten overleden gedurende het verblijf in het ziekenhuis. Van de geriatrische patiënten overlijden er 18 tijdens opname (T-test, $\mathrm{p}=0.002$ ). 
Tabel 4.3.1.4 Consulten tijdens opname (percentage).

Vergelijking van de steekproef van referenten $(n=100)$ met de steekproef geriatrische patiënten $(n=100)$.

\begin{tabular}{|c|c|c|c|}
\hline Consulten & Referenten & $\begin{array}{l}\text { Geriatrische } \\
\text { patiënten }\end{array}$ & p-waar \\
\hline Neuroloog & 11 & 31 & $=0.001$ \\
\hline Psychiater & 2 & 36 & $=0.000$ \\
\hline Uroloog & 1 & 8 & $<0.05$ \\
\hline Revalidatiearts & 3 & 11 & $<0.05$ \\
\hline
\end{tabular}

$\chi^{2}$ of Fischer Exact Test.

N.B.: overige consulten geen significante verschillen.

\subsubsection{Gegevens met betrekking tot funktioneren.}

\subsubsection{ADL-funktioneren}

Uit tabel 4.3.2.1A blijkt het ADL-funktioneren bij opname significant beter te zijn in de referentiepopulatie.

Tabel 4.3.2.1A ADL-funktioneren bij opname (percentages).

Vergelijking van de steekproef van referenten $(n=100)$ met de steekproef geriatrische patiènten $(n=100)$.

\begin{tabular}{lccl}
\hline ADL-Opname & Referenten & $\begin{array}{l}\text { Geriatrische } \\
\text { patiënten } \\
\mathrm{n}=100\end{array}$ & p-waarde \\
\hline Zn=100 & 33 & 10 & \\
Zelfstandig & 28 & 23 & \\
Discontinue hulp & 39 & 67 & $<0.000$ \\
Totantinue hulp & 100 & 100 & \\
\hline
\end{tabular}

$\chi^{2}$

Dit verschil wordt met name veroorzaakt door het veel grotere percentage geriatrische patiënten die volledig zorgafhankelijk zijn op het moment van opname.

Ook bij ontslag blijkt het verschil significant (tabel 4.3.2.1B). Overigens blijkt de geriatrische patiēnt bij ontslag t.o.v. de opnamesituatie duidelijk verbeterd. Deze vooruitgang is t.o.v. de referentiepopulatie zelfs significant groot. 
Tabel 4.3.2.11B Niet-overleden patiënten: ADL-funktioneren bij ontslag (percentages). Vergelijking van de steekproef van referenten $(n=100)$ met de steekproef geriatrische patiënten $(n=100)$.

\begin{tabular}{lccl}
\hline ADL-Ontslag & Referenten & $\begin{array}{l}\text { Geriatrische } \\
\text { patiënten } \\
\mathrm{n}=82\end{array}$ & p-waarde \\
\hline Zelfstandig & 50 & 17 & \\
Discontinue hulp & 37 & 42 & \\
Continue hulp & 13 & 42 & $<0.000$ \\
Totaal & 100 & 100 & \\
\hline
\end{tabular}

$x^{2}$

\subsubsection{Mobiliteit}

De mobiliteit bij opname en ontslag is significant verschillend in beide populaties, wederom ten gunste van de referentiepopulatie.

Tabel 4.3.2.2A Mobiliteit bij opname (percentages).

Vergelijking van de steekproef van referenten $(n=100)$ met de steekproef geriatrische patiënten $(n=100)$.

\begin{tabular}{lccl}
\hline Mobiliteit & Referenten & $\begin{array}{l}\text { Geriatrische } \\
\text { patiënten } \\
\mathrm{n}=100\end{array}$ & p-waarde \\
\hline Zelfstandig & 49 & 32 & \\
Personele hulp & 9 & 28 & \\
Bedlegerig & 42 & 40 & $<0.005$ \\
Totaal & 100 & 100 & \\
\hline
\end{tabular}

$\chi^{2}$

Tabel 4.3.2.2B Niet-overleden patiënten: Mobiliteit bij ontslag (percentages).

Vergelijking van de steekproef van referenten $(n=100)$ met de steekproef geriatrische patiënten $(n=100)$.

\begin{tabular}{lccl}
\hline Mobiliteit & Referenten & $\begin{array}{l}\text { Geriatrische } \\
\text { patiënten } \\
\mathrm{n}=82\end{array}$ & p-waarde \\
\hline Zelfstandig & $\mathrm{n}=96$ & 61 & \\
Personele hulp & 73 & 33 & \\
Bedlegerig & 18 & 6 & \\
Totaal & 9 & 100 & $<0.005$ \\
\hline
\end{tabular}

$\chi^{2}$ 
Overigens blijkt de geriatrisch patiënt bij ontslag t.o.v. de opnamesituatie duidelijk verbeterd. Deze vooruitgang is t.o.v. de referentiepopulatie zelfs significant groot.

\subsubsection{Incontinentie}

Zowel bij opname als bij ontslag komt het probleem urine-incontinentie bij de referentiepopulatie significant minder voor dan bij de geriatrische patiënten.

Tabel 4.3.2.3A Incontinentie bij opname (percentages).

Vergelijking van de steekproef van referenten $(n=100)$ met de steekproef geriatrische patiënten $(n=100)$.

\begin{tabular}{lccl}
\hline Incontinentie & Referenten & $\begin{array}{l}\text { Geriatrische } \\
\text { patiënten } \\
\mathrm{n}=100\end{array}$ & p-waarde \\
\hline Niet incontinent & 59 & 31 & \\
Zelden incontinent & 8 & 21 & \\
Frequent incontinent & 8 & 19 & \\
Catheter & 24 & 29 & $<0.000$ \\
Totaal & 100 & 100 & \\
\hline
\end{tabular}

$\chi^{2}$

Tabel 4.3.2.3B Niet-overleden patiënten: Incontinentie bij ontslag (percentages).

Vergelijking van de steekproef van referenten $(n=100)$ met de steekproef geriatrische patiënten $(n=100)$.

\begin{tabular}{lccc}
\hline Incontinentie & $\begin{array}{l}\text { Referenten } \\
\mathrm{n}=96\end{array}$ & $\begin{array}{l}\text { Geriatrische } \\
\text { patiënten } \\
\mathbf{n}=82\end{array}$ & p-waarde \\
\hline Niet incontinent & 72 & 47 & \\
Zelden incontinent & 2 & 28 & \\
Frequent incontinent & 15 & 19 & \\
Catheter & 11 & 6 & $<0.000$ \\
Totaal & 100 & 100 & \\
\hline
\end{tabular}

$x^{2}$

Overigens blijkt de geriatrisch patiënt bij ontslag t.o.v. de opnamesituatie duidelijk verbeterd. Deze vooruitgang is t.o.v. de referentiepopulatie zelfs significant groter. 


\subsubsection{Diagnoses}

In de geriatrische populatie komen significant vaker gastro-intestinale problemen, psychiatrische stoornissen, stoornissen van het bewegingsapparaat en urologische problemen voor. Opname ten gevolge van een ongeval wordt bijna vijf maal zo frequent waargenomen in de referentiepopulatie (tabel 4.3.3.1).

Tabei 4.3.3.1 Diagnosegroepen (percentages).

Vergelijking van de steekproef van referenten $(n=100)$ met de steekproef geriatrische patiënten $(n=100)$.

\begin{tabular}{lccl}
\hline $\begin{array}{l}\text { Afwijking/ } \\
\text { Diagnosegroep }\end{array}$ & Referenten & $\begin{array}{l}\text { Geriatrische } \\
\text { patiënten } \\
\mathrm{n}=100\end{array}$ & p-waarde \\
\hline Gastro-intestinale & 25 & 44 & $<0.05$ \\
Haematologische & 21 & 26 & NS \\
Nefrologische & 23 & 14 & NS \\
Psychiatrische & 11 & 54 & $<0.001$ \\
Neurologische & 21 & 32 & NS \\
Pulmonale & 21 & 23 & NS \\
Oogheelkundige & 5 & 11 & NS \\
KNO & 13 & 7 & NS \\
Bewegingsapparaat & 5 & 35 & $<0.001$ \\
Urologische & 17 & 39 & $<0.01$ \\
Gynaecologische & 2 & 1 & NS \\
Tumoren & 13 & 15 & NS \\
Dermatologische & 10 & 14 & nvt \\
Suicide & 0 & 0 & NS \\
Intoxicaties & 2 & 5 & $<0.001$ \\
Ongevallen & 23 & 5 & NS \\
Endocriene & 24 & 23 & NS \\
Cardiovasculaire & 44 & 36 & \\
Rheumatologische & 4 & 1 & \\
\hline
\end{tabular}

$\chi^{2}$

\subsubsection{Therapie}

Beide groepen ontvangen in vergelijkbare percentages medicamenteuze therapie, parenterale vochttoediening en sondevoeding.

De referentiepopulatie wordt gedurende opname in het ziekenhuis ruim tweemaal zo vaak geopereerd.

De geriatrische patiënten daarentegen krijgen significant vaker fysiotherapie, ADL-training en hulp van het maatschappelijk werk (tabel 4.3.4.1). 
Tabel 4.3.4.1 Therapieën (percentages).

Vergelijking van de steekproef van referenten $(n=100)$ met de steekproef geriatrische patiën$\operatorname{ten}(n=100)$.

\begin{tabular}{lcll}
\hline Therapie & Referenten & $\begin{array}{l}\text { Geriatrische } \\
\text { patiënten } \\
\mathrm{n}=100\end{array}$ & $\mathrm{p}$-waarde \\
\hline Medicamenteus & 88 & 94 & $\mathrm{NS}$ \\
Infuus & 65 & 56 & $\mathrm{NS}$ \\
Sonde & 8 & 11 & $\mathrm{NS}$ \\
Dieet & 9 & 39 & $<0.001$ \\
Operatie & 36 & 16 & $<0.01$ \\
Fysiotherapie & 17 & 83 & $<0.001$ \\
ADL-training & 0 & 28 & $<0.001$ \\
Maatschappelijk werk & 27 & 45 & $<0.01$ \\
\hline
\end{tabular}

$x^{2}$

\subsubsection{Ontslagrichting}

Het percentage geriatrische patiënten dat niet terugkeert naar de oorspronkelijke woonsituatie bedraagt $41 \%$. Belangrijkste alternatieven zijn het verzorgingstehuis (13\%), het somatisch verpleeghuis (10\%) en het psycho-geriatrisch verpleeghuis (11\%). Van de referentiepopulatie keert $86 \%$ terug naar de oorspronkelijke woonsituatie. Van de overigen gaat het grootste deel naar het somatisch verpleeghuis (11\%) (tabel 4.3.5.1).

Tabel 4.3.5.1 Niet-overleden patiënten: Ontslagrichting (percentages).

Vergelijking van de steekproef van referenten $(n=100)$ met de steekproef geriatrische patiënten $(n=100)$.

\begin{tabular}{lcl}
\hline Ontslagrichting & Referenten & $\begin{array}{l}\text { Geriatrische } \\
\text { patiënten } \\
\mathrm{n}=82\end{array}$ \\
\hline Oorspronkelijke woonsituatie & 86 & 59 \\
Andere ziekenhuisafdeling & 3 & 0 \\
Verzorgingstehuis & 0 & 13 \\
Somatisch verpleeghuis & 11 & 10 \\
Psychoger. Verpleeghuis & 0 & 11 \\
Psychiatrisch ziekenhuis & 0 & 4 \\
\hline
\end{tabular}

NB: oorspronkelijke woonsituatie versus overige ontslagindelingen, $\chi^{2} ; p<0.001$. 
4.4 De vergelijking van de geriatrische patiënten $(n=84)$ en de referentie populatie $(n=64)$, gecorrigeerd voor operaties

Het relatief grote verschil in het percentage geopereerde patiënten in beide groepen kan de veronderstelling wekken dat de verschillen mede hierdoor bepaald worden. Dit zou met name het geval kunnen zijn voor de funktionele parameters bij ontslag.

Uit de gegevens blijkt - opvallend genoeg - dat alle geopereerden in beide groepen behoren tot de categorie niet-overleden patiënten. Het verschil in ADL-funktioneren bij ontslag blijft significant. Het iets groter verschil in zelfstandige mobiliteit ten gunste van de referentiepopulatie veroorzaakt een niet significant verschil wat betreft mobiliteit bij ontslag. Het aantal patiënten met een catheter bij ontslag is in beide groepen wat lager, wanneer bovenvermelde restrictie wordt toegepast; het verschil in incontinentieproblematiek blijft overigens significant (tabel 4.4.1).

Tabel 4.4.1 Niet-geopereerde patiënten: Funktioneren bij ontslag. Idem als tabel 4.3.1.1 (percentages).

\begin{tabular}{lll}
\hline & Referenten & $\begin{array}{l}\text { Geriatrische } \\
\text { patiënten } \\
n=66\end{array}$ \\
\hline
\end{tabular}

\section{- ADL-ontslag}

Zelfstandig

Discontinue hulp

Continue hulp

54

37

9

Totaal

-Mobiliteit ontslag

Zelfstandig

Met personele hulp

Bedlegerig

Totaal

- Incontinentie ontslag

Niet incontinent

Zelden incontinent

Frequent incontinent

Catheter

Totaal
100

82

12

7

100

78

2

12

8

100
18

41

41

100

$<0.001$

61

33

6

100

$<0.05$

44

26

23

8

$\chi^{2}$ 
Analyse van de verschillen tussen de 96 niet-overleden patiënten in de referentiepopulatie en de 82 niet-overleden patiënten in de geriatrische populatie brengt geen veranderingen aan het licht voor wat betreft de gevonden verschillen tussen beide populaties als geheel.

\subsection{Bespreking}

Bij analyse van de verschillen tussen de referentiepopulatie en de geriatrische patiënten blijkt dat, alhoewel beide populaties geen verschil vertonen voor leeftijd, geslachtsverdeling, burgerlijke staat en woonsituatie voor opname, het verschil voor de overige parameters aanzienlijk is. Reeds bij aanvang van de opname worden een aantal verschillen geconstateerd die de veel grotere mate van hulpbehoefte van de geriatrische patiënten aangeven: zij maken meer gebruik van voorzieningen in de eerste lijn en ontvangen meer mantelzorg.

Ook blijkt dat het bijna driemaal zo frequent voorkomt dat zij in de twaalf maanden voorafgaand aan het onderzoek ook al één of meer malen in het ziekenhuis zijn opgenomen. Alhoewel de gegevens over de voorafgaande opnames ontbreken, lijkt het waarschijnlijk dat in een aanzienlijk aantal er een samenhang bestaat met de onderzochte opname. Kennelijk is het niet mogelijk gebleken de zorgvraag afdoende te beantwoorden in andere opnames. Mogelijk hangt dit samen met de aanwezigheid van multiple pathologie. Opvallend is in ieder geval dat, alhoewel een significant verschil bestaat, toch beide populaties voor het overgrote deel een somatische opname-indicatie hebben. De bijdrage van psychische, cognitieve en/of sociale factoren is in de geriatrische populatie, zoals verwacht, aanzienlijk groter. Hieraan is het meer voorkomen van psychische stoornissen waarschijnlijk debet.

Het verschil in het aantal consulenten kan niet zonder meer worden toegeschreven aan multiple pathologie. Ook de interventie van het geriatrisch behandelteam kan dit hebben veroorzaakt. De specialismen die dit met name betreft zijn immers nauw gelieerd aan specifieke geriatrische problematiek, zoals recidiverend vallen, incontinentie, mobiliteitsstoornissen en psychische problematiek.

Het verschil in opnameduur kan meerdere verklaring hebben. Naast een langere gemiddelde duur voor herstel speelt hierbij ongetwijfeld een rol dat ruim $40 \%$ van de patiënten niet terugkeert naar de oorspronkelijke woonsituatie. Wachttijden voor verzorgingstehuizen en verpleeghuizen verklaren ongeveer $50 \%$ van het verschil: de gemiddelde opnameduur voor de geriatrische patiënten die wel terugkeren naar de oorspronkelijke woonsituatie bedraagt 28,7 dagen. Een ander deel van het verschil kan daarbij verklaard worden uit de extra tijd die nodig is om de zorg in de oorspronkelijke woonsituatie te optimaliseren, bijvoorbeeld aanvragen of uitbreiden van gezinszorg en/of wijkverpleging. 
De gemiddelde opnameduur van de referentiepopulatie komt overeen met de landelijke gemiddelde opnameduur van patiënten ouder dan 65 jaar. Een toename van de vergrijzing en de geconstateerde herhaalde opnames van geriatrische patiënten zal de gemiddelde opnameduur verder doen toenemen. Dit effect wordt nog versterkt door de (te) beperkte groei in het aantal verpleeghuisbedden en de inkrimping van het aantal verzorgingstehuisplaatsen.

Uit het percentage overleden patiënten blijkt dat het overlijdensrisico van geriatrische patiënten aanzienlijk hoger ligt dan in de referentiepopulatie. Naast de gekende verschuiving in de verhouding tussen cure en care bij geriatrische patiënten stelt dit ook andere eisen aan de voorzieningen voor terminale patiënten in de ruimste zin des woords.

De grotere hulpbehoefte van geriatrische patiënten blijkt het sterkst uit de gegevens met betrekking tot het funktioneren. Wanneer deze gegevens gecorrigeerd worden voor operatief ingrijpen - in hoofdzaak om ongevalsletsels is het verschil tussen beide groepen nog groter. Het is niet ondenkbaar dat de geconstateerde overige verschillen tussen beide populaties in veel opzichten eerder door deze validiteitsverschillen bepaald worden dan door verschillen in morbiditeit.

De verschillen in morbiditeit c.q. diagnosegroepen geven daarbij wel nog een extra dimensie aan de gezondheidszorg voor geriatrische populatie: veel minder frequent komen zij in het ziekenhuis terecht voor chirurgisch ingrijpen in vergelijking met de normale oudere patiënt.

Resumerend kan geconcludeerd worden dat de onderzochte groep geriatrische patiënten daadwerkelijk en in vrijwel alle opzichten zich onderscheidt van 'gewone ouderen' in het ziekenhuis. Op grond van de gevonden verschillen kan een geriatrische patiënt die opgenomen wordt in het ziekenhuis als volgt worden omschreven:

een patiënt die veelal een uitgebreid zorgsysteem heeft in zijn of haar oorspronkelijke woonsituatie, maar (desondanks) herhaald wordt opgenomen in het ziekenhuis, waarbij naast somatische factoren niet zelden psychische, cognitieve of sociale aspecten een belangrijke rol spelen. De gemiddelde opnameduur van een dergelijke patiënt is significant langer dan van gewone ouderen, het overlijdensrisico hoger en de hulpbehoevendheid blijft hoog ondanks dat mobiliteitsstoornissen verhoudingsgewijs goed toegankelijk zijn voor therapie.

Specifieke aandacht is noodzakelijk voor stoornissen in het psychische vlak, urologische problematiek en afwijkingen aan het houdings- en bewegingsapparaat. Medische interventies zijn relatief zelden chirurgisch van aard. De kans om terug te keren naar de oorspronkelijke woonsituatie is significant lager dan bij de doorsnee oudere patiënt. 
Bijlage I-A Achtergrondgegevens.

Vergelijking van de steekproef van 100 geriatrische patiënten met het totale bestand patiënten minus die steekproef $(n=546)$. Gegevens vermeld in procenten van 100 resp. 546.

\begin{tabular}{lll}
\hline Steekproef & $\begin{array}{l}\text { Overige } \\
\text { geriatrische } \\
\text { patiënten } \\
(\%)\end{array}$ \\
\hline
\end{tabular}

\section{- Geslacht} vrouwen

mannen

- Leeftijd

$\leq 75$ ir

$76-85 \mathrm{jr}$

$>85 \mathrm{jr}$

- Burgelijke staat

gehuwd

gescheiden

ongehuwd

weduwstaat

samenwonen

- Woonsituatie

zelfstandig

bij kinderen

verzorgingstehuis

som.Verpleeghuis

psychoger.Verpleeghuis

- Lulpverlening

funilie

particulier

uvv

gezinszorg

dienstencentrum

wijkverpleging

RIACiC;

vequleeghuis (Jagheh.)
63

37

20

45

35

38

2

15

43

2

61

8

29

1

1

72

6

2

4

3

16

14

4
63

37

$\mathrm{NS}^{1}$

17

55

28

$N S^{1}$

28

2

11

57

0

$\mathrm{NS}^{2}$

60

10

27

2

1

$\mathrm{NS}^{2}$

70

7

1

42

2

23

12

$\mathrm{NS}^{2}$ 


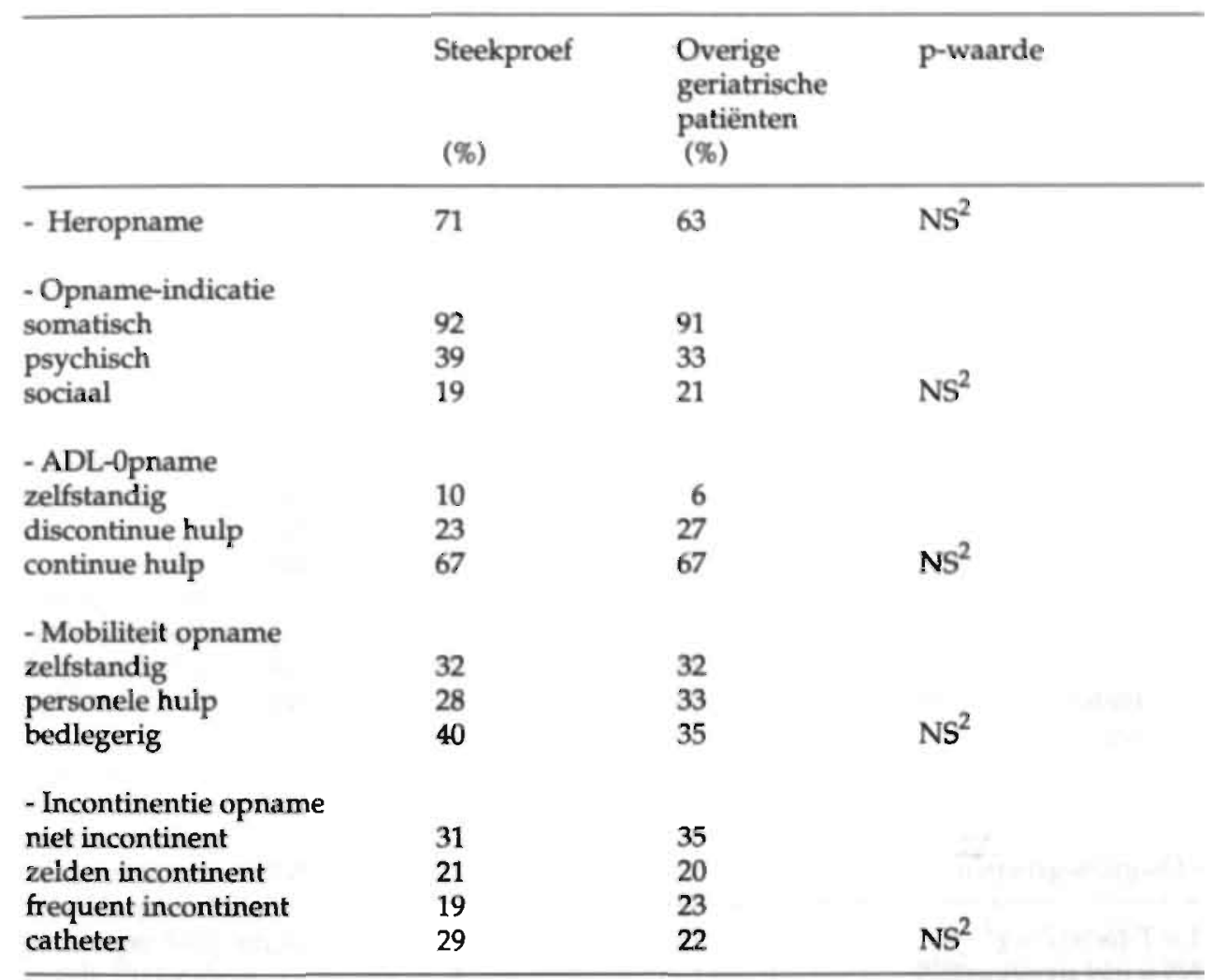

${ }^{1}=t$-Toets; ${ }^{2}=\chi^{2}$

NS $=$ niet significant 
Bijlage 1-C Klinische gegevens.

\begin{tabular}{lccl}
\hline & Steekproef & $\begin{array}{l}\text { Overige } \\
\text { geriatrische } \\
\text { patiënten } \\
(\%)\end{array}$ & $\mathrm{p}$-waarde \\
\hline - Overlijden & $(\%)$ & 15 & $\mathrm{NS}^{1}$ \\
- Therapie: & 18 & & \\
medikamenten & 94 & 94 & $\mathrm{NS}^{2}$ \\
infuus & 56 & 52 & $\mathrm{NS}^{2}$ \\
sonde & 11 & 8 & $\mathrm{NS}^{2}$ \\
dieet & 39 & 38 & $\mathrm{NS}^{2}$ \\
operatie & 16 & 15 & $\mathrm{NS}^{2}$ \\
fysiotherapie & 83 & 79 & $\mathrm{NS}^{2}$ \\
ADL-training & 28 & 36 & $\mathrm{NS}^{2}$ \\
maatsch. Werk & 45 & 48 & $\mathrm{NS}^{2}$ \\
- Consulten & & & $\mathrm{NS}^{2}$ \\
neuroloog & 31 & 30 & $\mathrm{NS}^{2}$ \\
psychiater & 36 & 28 & $\mathrm{NS}^{2}$ \\
uroloog & 8 & 12 & $\mathrm{NS}^{2}$ \\
orthopeed & 5 & 9 & \\
revalidatiearts & 11 & & \\
- Diagnosegroepen & & & \\
\hline
\end{tabular}

$1=T$-toets $; 2=\chi^{2}$

NS $=$ niet significant 


\begin{tabular}{|c|c|c|c|}
\hline & $\begin{array}{l}\text { Steekproef } \\
(\%)\end{array}$ & $\begin{array}{l}\text { Overige } \\
\text { geriatrische } \\
\text { patiënten } \\
(\%)\end{array}$ & p-waarde \\
\hline \multicolumn{4}{|l|}{ - ADL-Ontslag } \\
\hline zelfstandig & 17 & 20 & \\
\hline discontinue hulp & 42 & 42 & \\
\hline continue hulp & 42 & 38 & $\mathrm{NS}^{2}$ \\
\hline \multicolumn{4}{|l|}{ - Mobiliteit ontslag } \\
\hline zelfstandig & 61 & 71 & \\
\hline personele hulp & 33 & 23 & \\
\hline bedlegerig & 6 & 4 & $\mathrm{NS}^{2}$ \\
\hline \multicolumn{4}{|l|}{ - Incontinentie ontslag } \\
\hline niet incontinent & 47 & 48 & \\
\hline zelden incontinent & 28 & 26 & \\
\hline frequent incontinent & 19 & 16 & \\
\hline catheter & 6 & 10 & $\mathrm{NS}^{2}$ \\
\hline \multicolumn{4}{|l|}{ - Ontslagrichting } \\
\hline oorspr. Woonsituatie & 59 & 64 & \\
\hline andere afdeling . & 0 & 1 & \\
\hline verzorgingstehuis & $\begin{array}{l}13 \\
10\end{array}$ & 12 & \\
\hline $\begin{array}{l}\text { som. Verpleeghuis } \\
\text { psychoger.Verpleeghuis }\end{array}$ & $\begin{array}{l}10 \\
11\end{array}$ & $\begin{array}{l}10 \\
11\end{array}$ & \\
\hline psych. Ziekenhuis & 4 & 1 & $\mathrm{NS}^{2}$ \\
\hline
\end{tabular}

$1=T$-toets $; 2=\chi^{2}$

$N S=$ niet significant 



\section{Hoofdstuk 5}

\section{Het geriatrische complex}

In dit hoofdstuk. komt aan de orde het algemene profiel van de patiëntengroep. Hierbij wordt ingegaan op de algemene variabelen, het ADL-funktioneren, de mobiliteit en de urine-incontinentie op het moment van opname. Vervolgens wordt nagegaan hoe de spreiding is van diagnoses of aktieve problemen en de onderlinge relatie hiertussen

$\mathrm{Na}$ deze eerste analyse wordt het begrip multiple pathologie nader uitgewerkt door het verrichten van een cluster-analyse op de 28 meest voorkomende (d.w.z. bij tenminste 5\% van de populatie aanwezige) diagnoses. Hiermee wordt de samenhang tussen de afzonderlijke diagnoses verduidelijkt en gepoogd inhoud te geven aan de begrippen multiple pathologie en complexe problematiek. Deze zogenaamde clusters worden vervolgens geanalyseerd in relatie tot het funktioneren bij opname, waarbij in het bijzonder aandacht wordt geschonken aan het meest opvallende cluster: het zogenaamde Geriatrisch Complex: een aantal samenhangende diagnoses/problemen dat bij een aanzienlijk deel van de patiënten wordt gevonden.

In de periode oktober 1988 tot januari 1990 zijn de gegevens verzameld van 646 opnames van geriatrische patiënten, behandeld in het kader van het Flankerend Geriatrisch Beleid. Uitgesplitst naar le opnames, heropnames en overlijden gaat het om 574 eerste opnames en 72 heropnames. Tijdens eerste opname overlijden 85 patiënten, tijdens heropname 15 patiënten (zie figuur 5.1).

Figuur 5.1 Samenstelling onderzochte patiëntenpopulaties naar heropname en overlijden.

\begin{tabular}{lcll}
\hline & 1e Opname & Heropname & Totaal \\
\hline Niet overleden & 489 & 57 & 546 \\
Wel overleden & 85 & 15 & 100 \\
Totaal & 574 & 72 & 646 \\
\hline
\end{tabular}

In de navolgende paragraaf worden de gegevens beschreven van de 489 patiënten die niet zijn overleden gedurende opname en voor de eerste keer 
behandeld zijn volgens de principes van het Flankerend Geriatrisch Beleid $(n=489)$. De overleden patiënten worden in een latere fase apart beschreven.

\subsection{Algemene karakteristiek}

De onderzoekspopulatie omvat bijna tweemaal zoveel vrouwen dan mannen (tabel 5.1). De gemiddelde leeftijd is 81,6 jaar. Bijna $60 \%$ van de patiënten is hoogbejaard, d.w.z. ouder dan 80 jaar. Tweederde van de patiënten heeft geen (levende) partner. Ongeveer éénkwart van de patiënten verblijft voor opname in een verzorgingstehuis en $3 \%$ is afkomstig uit een verpleeghuis. De overige patiënten verblijven in de thuissituatie, al dan niet samenwonend met kinderen. Slechts een kleine minderheid $(10 \%)$ is voor opname volledig zelfstandig. Bij $77 \%$ is sprake van informele zorg (familie/buren/particulaire hulp), bijna de helft heeft gezinszorg en $20 \%$ maakt gebruik van de diensten van de wijkverpleging. Een kleine minderheid $(2 \%)$ is op het moment van opname in dagbehandeling in een verpleeghuis.

Voor het merendeel van de opnames geldt dat er sprake is van een spoedopname $(84 \%)$. Eénderde van de patiënten die behandeld zijn volgens het Flankerend Geriatrisch Beleid is minder dan éen jaar geleden ook al opgenomen geweest in het ziekenhuis. Eénderde is nooit eerder in een ziekenhuis opgenomen geweest.

De patiënten zijn hoofdzakelijk verwezen via de huisarts $(73 \%)$ en bijna allemaal afkomstig uit het directe verzorgingsgebied van het Academisch Ziekenhuis Maastricht.

Wanneer de opname-indicatie wordt uitgesplitst naar somatische, psychisch/cognitieve en/of sociale motieven, zoals beschreven in hoofdstuk III heeft $91 \%$ een somatische, $20 \%$ een psychisch/cognitieve en $21 \%$ een sociale opname-indicatie. Uitsluitend een sociale indicatie bestaat bij $4 \%$ van de patiënten.

De mediane opnameduur bedraagt 29 dagen. $20 \%$ Verblijft meer dan 58 dagen in het ziekenhuis, $21 \%$ minder dan 14 dagen.

Een kleine minderheid van de patiënten is bij opname ADL-zelfstandig, bijna tweederde is in belangrijke mate of geheel ADL-afhankelijk (tabel 5.1.2).

Ruim éénderde van de patiënten is bedlegerig. Van de niet bedlegerige patiënten is bijna de helft afhankelijk van personele begeleiding (tabel 5.1.3).

Meer dan éénvijfde van de patiënten heeft bij opname een urinecatheter (gekregen) (tabel 5.1.4). Van de patiënten die geen catheter hebben bij opname is exact $25 \%$ volledig of vrijwel volledig incontinent, de overige patiënten zijn niet $(49 \%)$ of slechts sporadisch $(26 \%)$ incontinent voor urine. 
Tabel 5.1.1A Algemene patièntengegevens: leeftijd, geslacht, en burgelijke staat.

\begin{tabular}{lrr}
\hline & \multicolumn{2}{c}{$\%$} \\
\hline$\leq 60$ jaar & 2 & 1 \\
$61-65$ jaar & 7 & 1 \\
$66-70$ jaar & 21 & 4 \\
$71-75$ jaar & 56 & 11 \\
$76-80$ jaar & 152 & 22 \\
$81-85$ jaar & 151 \\
$86-90$ jaar & 41 & 20 \\
$\geq 90$ jaar & 489 & 8 \\
& 318 & 100 \\
& 171 & 35 \\
Vrouwen & 489 & 100 \\
Mannen & 146 & 30 \\
& 9 & 2 \\
Gehuwd & 54 & 11 \\
Gescheiden & 264 & 54 \\
Ongehuwd & 5 & 1 \\
Weduwstaat & 9 & 2 \\
Samenwonend & \multicolumn{100}{c}{$\%$} \\
Onbekend & 489 & 100 \\
\hline
\end{tabular}

Tabel 5.1.1B Algemene patiëntengegevens: woonsituatie en hulpverlening voor opname:

\begin{tabular}{lrr}
\hline & \multicolumn{1}{c}{ n } & \multicolumn{1}{c}{$\%$} \\
\hline Zelfstandig alleen & 192 & 39 \\
Zelfstandig met partner & 117 & 24 \\
Inwonend bij familie & 51 & 10 \\
Verzorgingstehuis & 117 & 24 \\
Verpleeghuis somatisch & 5 & 1 \\
Verpleeghuis psychosomatisch & 5 & 1 \\
Onbekend & 2 & 1 \\
& 489 & 100 \\
Geen & & \\
Familie/buren & 47 & 10 \\
Particulier & 343 & 70 \\
Gezinszorg & 36 & 7 \\
Wijkzuster & 195 & 0 \\
RIAGG/SPGD & 99 & 20 \\
Dagbehandeling verpleeghuis & 61 & 12 \\
\hline
\end{tabular}

SPGD $=$ Sociaal Psycho-Geriatrische Dienst 
Tabel 5.1.2 ADL-funktioneren bij opname " (geriatrische, patiënten, $1^{\mathrm{e}}$ opname, niet overleden).

\begin{tabular}{|c|c|c|}
\hline ADL & $\mathrm{n}$ & $\%$ \\
\hline Zelfstandig & 40 & 8 \\
\hline Discontinue zorgbehoefte & 139 & 29 \\
\hline Continue zorgbehoefte & 298 & 63 \\
\hline Totaal & $\overline{477}$ & $\overline{100}$ \\
\hline \multicolumn{3}{|l|}{ onbekende data $n=12$} \\
\hline & $\mathbf{n}$ & $\%$ \\
\hline Niet bedlegerig & 337 & 69 \\
\hline Bedlegerig & 148 & 31 \\
\hline Totaal & $\overline{485}$ & $\overline{100}$ \\
\hline
\end{tabular}

ontbrekende data $n=4$

Tabel 5.1.3B Mobiliteit niet bedlegerige patiënten bij opname

\begin{tabular}{llc}
\hline Mobiliteit & n & $\%$ \\
\hline Zelfstandig & 170 & 52 \\
Personele hulp & $\mathbf{1 5 6}$ & $\mathbf{4 8}$ \\
Totaal & $\overline{326}$ & $\overline{100}$ \\
\hline
\end{tabular}

ontbrekende data $n=11$

Tabel 5.1.4A Cathetergebruik bij opname *

\begin{tabular}{lll}
\hline & $\mathrm{n}$ & $\%$ \\
\hline Geen catheter & 384 & 79 \\
Wel catheter & $\overline{101}$ & $\overline{21}$ \\
Totaal & $\overline{485}$ & $\overline{100}$ \\
\hline
\end{tabular}

ontbrekende data $n=4$ 
Tabel 5.1.4B Urine-incontinentie bij opname van patiënten die geen catheter hebben bij opname

\begin{tabular}{lrr}
\hline Incontinentie & $\mathrm{n}$ & $\%$ \\
\hline Niet incontinent & 178 & 49 \\
Zelden incontinent & 95 & 26 \\
Frequent incontinent & 91 & 25 \\
Totaal & $\overline{364}$ & $\overline{100}$ \\
\hline
\end{tabular}

"ontbrekende data $n=20$

\subsection{De diagnoses}

Het aantal aktieve diagnoses gedurende opname wisselt van patiënt tot patiënt sterk.

Hoewel zal blijken dat de diagnoses/problemen sterk uiteenlopend van karakter zijn, is in het kader van de analyse van het probleem "multiple pathologie" nagegaan hoe de diagnoses kwantitatief verdeeld zijn over de patiëntengroep.

In het totale patiëntenbestand zijn 2799 aktieve diagnoses/problemen benoemd, wat een gemiddelde van 5.7 per patiënt betekent.

In totaal zijn 514 verschillende diagnoses gesteld bij de 489 patiënten. Voor de frequentieverdeling: zie tabel 5.2.1.

Tabel 5.2.1 Frequentieverdeling aktieve diagnoses/problemen bij onderzochte geriatrische patiënten $(n=489)$.

Aantal aktieve

Diagnoses/problemen

n $\quad \%$

0

1

2

$1 \quad(0)$

$7 \quad$ (1)

23

$3 \quad 47$

$4 \quad 72$

5

$6 \quad 79 \quad$ (16)

$7 \quad 68 \quad$ (14)

$8 \quad 41 \quad(8)$

$9 \quad 31 \quad 32$

$10 \quad 32 \quad(7)$

$\begin{array}{lll}\text { Total } & \overline{489} & \overline{100}\end{array}$

N.B.: gemiddeld 5,7 diagnoses per patiënt (SD 2,2). 
Bij opname hebben bedlegerige patiënten gemiddeld 6,3 aktieve diagnoses. De niet bedlegerige patiënten hebben gemiddeld 5,5 aktieve diagnoses ( $T$-test, $\mathrm{p}=0.000$ ).

Wanneer de invloed van de ziekte uitsluitend kwantitatief wordt gemeten bestaat er dus een relatie tussen bedlegerigheid en ziektelast in de onderzochte patiëntengroep.

Bij opname hebben/krijgen 101 patiënten een catheter. Gemiddeld hebben deze patiënten 6,8 diagnoses tegenover 5,5 diagnoses bij de patiënten die geen catheter hebben ( $\mathrm{T}$-test, $\mathrm{p}=0.000$ ).

Patiënten met een catheter zijn gemiddeld bij opname in kwantitatieve zin zieker dan patiënten zonder catheter.

Uitgesplitst naar afzonderlijke ziektebeelden zijn er 28 diagnoses/problemen, die bij tenminste $5 \%$ van de patiënten voorkomen (tabel 5.2.2).

De onderlinge samenhang tussen de verschillende diagnoses, de correlatie coëfficiënt, is laag (zie tabel 5.2.3). De sterkste correlatie wordt gevonden tussen visus- en gehoorstoornissen $(R=0.29, p=0.000)$. Op zichzelf is dit verwonderlijk, d.w.z. niet klinisch verklaarbaar. Echter in absolute aantallen uitgedrukt gaat het om een beperkt aantal. Bij 50 patiënten met gehoorstoornissen en 29 met visusstoornissen is het verwachte aantal dat beide stoornissen heeft: 3 (nl. $50 \times 29: 489$ ). In werkelijkheid is het aantal waarbij beide stoornissen voorkomen 13 .

Een verklaring voor de in het algemeen zwakke correlatie kan zijn dat bij de onderzochte patiëntengroep eerder sprake is van multiple pathologie op basis van multi-organ failure, dan van een veelheid aan uitingen van eenzelfde orgaanprobleem. Dit sluit aan bij de gedachte dat een intercurrente aandoening bij geriatrische patiënten het wankel evenwicht dusdanig verstoort dat onmiddellijk een veelheid van problemen ontstaat op het somatisch psychisch en sociale vlak.

De correlatie van ziektebeelden met basale variabelen zoals de leeftijd is gering. (tabel 5.2.4). Wanneer als ondergrens een correlatie coëfficient groter dan 0.10 wordt gehanteerd blijkt dat alleen heupfrakturen, dehydratie en gehoorstoornissen vaker voorkomen naarmate patiënten ouder zijn, terwijl verwardheid en hypertensie een omgekeerde relatie met de leeftijd vertonen. Een mogelijke verklaring voor dit laatste kan zijn dat de diagnose hypertensie minder frequent expliciet wordt gesteld bij hoogbejaarden omdat de therapeutische betekenis hiervan onduidelijk is.

Minstens zo belangrijk als het wel vinden van een correlatie is de constatering dat voor de meeste diagnoses geldt dat een correlatie met de leeftijd ontbreekt in de onderzochte patiëntencategorie.

Hetzelfde blijkt te gelden voor een andere basale variabele: het geslacht. 
Tabel 5.2.2 Diagnoses/problemen voorkomend bij > 5\% van de patiënten $(n=489)$. In volgorde van frequentie.

\begin{tabular}{|c|c|c|c|}
\hline & $\mathbf{n}$ & $\begin{array}{l}\text { Patiënten } \\
\%\end{array}$ & $\begin{array}{l}\text { Totaal aantal } \\
\text { diagnoses } \\
\%\end{array}$ \\
\hline Verzorgingsproblematiek & 154 & 32 & 6 \\
\hline Dementie & 143 & 29 & 5 \\
\hline Acute incontinentie & 96 & 20 & 3 \\
\hline Diabetes & 86 & 18 & 3 \\
\hline Anemie & 81 & 17 & 3 \\
\hline Acute immobilisatie & 77 & 16 & 3 \\
\hline Decompensatio cordis & 77 & 16 & 3 \\
\hline Urineweginfekties & 71 & 14 & 3 \\
\hline Obstipatie & 66 & 14 & 2 \\
\hline Atriumfibrilleren & 65 & 13 & 2 \\
\hline Dehydratie & 61 & 12 & 2 \\
\hline CARA & 54 & 11 & 2 \\
\hline Cognitieve stoornissen & 52 & 11 & 2 \\
\hline Gehoorstoornis & 50 & 10 & 2 \\
\hline Loopstoornissen & 49 & 10 & 2 \\
\hline Gewichtsverlies & 47 & 10 & 2 \\
\hline CVA & 44 & 9 & 2 \\
\hline Vitarnine B6-deficiëntie & 37 & 8 & 1 \\
\hline Acute verwardheid & 35 & 7 & 1 \\
\hline Depressie & 32 & 7 & 1 \\
\hline Nierfunktiestoornis & 30 & 6 & 1 \\
\hline Heupfraktuur & 30 & 6 & 1 \\
\hline Vallen & 29 & 6 & 1 \\
\hline Decubitus & 29 & 6 & 1 \\
\hline Visusstoornissen & 29 & 6 & 1 \\
\hline Pneumonie & 28 & 6 & 1 \\
\hline Hypertensie & 27 & 6 & 1 \\
\hline Myocardinfarct & 26 & 5 & 1 \\
\hline Totaal & $\overline{1605}$ & & $\overline{58}$ \\
\hline
\end{tabular}

Gemiddeld 3,3 genoemde diagnoses per patiënt (SD 1,7).

Pneumonie, CARA, CVA en incontinentie worden vaker aangetroffen bij mannen. Urineweginfekties, visusstoornissen en (vanzelfsprekend) heupfrakturen komen vaker voor bij vrouwen.

Al deze correlaties zijn echter zwak tot zeer zwak, ondanks de gevonden significantie.

Wanneer de afzonderlijke diagnoses worden gecorreleerd aan het funktioneren bij opname is het beeld niet veel gunstiger. Een aantal heeft in het geheel geen verband met het funktioneren (tabel 5.2.5), terwijl voor alle diagnoses 
Tabel 5.2.3 De correlaties van de 28 meest voorkomende diagnoses uit tabel 5.2.2 met elkaar. Alleen correlaties $\geq .10$ worden vermeld.

\begin{tabular}{|c|c|c|c|}
\hline Diagnose & Diagnose & $\mathbf{R}$ & p-waarde \\
\hline \multirow[t]{2}{*}{ Verzorgingsprobl. } & Cogn.funktiest. & 0.19 & $<0.000$ \\
\hline & Anemie & -0.11 & $<0.01$ \\
\hline \multirow{4}{*}{ Dementie } & B6 deficiëntie & 0.17 & $<0.000$ \\
\hline & Decomp. cordis & -0.11 & $<0.01$ \\
\hline & Depressie & -0.13 & $<0.01$ \\
\hline & Obstipatie & -0.14 & $=0.001$ \\
\hline \multirow{4}{*}{$\begin{array}{l}\text { Incontinentie } \\
\text { (acuut) }\end{array}$} & Pneumonie & 0.28 & $<0.000$ \\
\hline & Acute loopst. & 0.16 & $<0.000$ \\
\hline & Acute Immob. & 0.11 & $<0.01$ \\
\hline & Gewichtsverlies & 0.10 & $<0.05$ \\
\hline \multicolumn{4}{|l|}{ Diabetes } \\
\hline \multirow[t]{2}{*}{ Anemie } & Nierfunktiest. & 0.12 & $=0.005$ \\
\hline & $\begin{array}{l}\text { B6 deficientie } \\
\text { (zie Verzorgingsproblematiek) }\end{array}$ & 0.10 & $<0.05$ \\
\hline \multirow[t]{2}{*}{ Acute Immobilisatie } & Heupfraktuur & 0.10 & $<0.05$ \\
\hline & $\begin{array}{l}\text { Loopstoornis } \\
\text { (zie Acute Incontinentie) }\end{array}$ & -0.13 & $<0.01$ \\
\hline \multirow[t]{2}{*}{ Decompensatio cordis } & Atriumfibr. & 0.28 & $<0.000$ \\
\hline & $\begin{array}{l}\text { Myocardinf. } \\
\text { (zie Dementie) }\end{array}$ & 0.23 & $<0.000$ \\
\hline Urineweginfekties & Dehydratie & 0.16 & $<0.000$ \\
\hline Obstipatie & $\begin{array}{l}\text { Gehoorst. } \\
\text { (zie Dementie) }\end{array}$ & 0.20 & $<0.000$ \\
\hline Atriumfibrilleren & $\begin{array}{l}\text { Dehydratie } \\
\text { (zie Decompensatio cordis) }\end{array}$ & 0.11 & $<0.01$ \\
\hline \multirow[t]{2}{*}{ Dehydratie } & Decubitus & 0.11 & $<0.01$ \\
\hline & $\begin{array}{l}\text { Depressie } \\
\text { (zie Urineweginf., Atriumfibr.) }\end{array}$ & 0.10 & $<0.05$ \\
\hline CARA & - & & \\
\hline \multirow{3}{*}{$\begin{array}{l}\text { Cogn.funktiest. } \\
\text { Gehoorst. }\end{array}$} & (zie Verzorgingsproblematiek) & & \\
\hline & Visusst. & 0.29 & $<0.000$ \\
\hline & Loopst. & 0.11 & $<0.01$ \\
\hline \multirow{2}{*}{$\begin{array}{l}\text { Loopstoornissen } \\
\text { Gewichtsverlies }\end{array}$} & (zie Acute Inc., Acute Immob., Ge & orst.) & \\
\hline & $\begin{array}{l}\text { Depressie } \\
\text { (zie Acute Incontinentie) }\end{array}$ & 0.14 & $=0.001$ \\
\hline \multirow[t]{2}{*}{ CVA } & Hypertensie & 0.14 & $=0.001$ \\
\hline & Pneumonie & 0.11 & $<0.01$ \\
\hline B6 deficiëntie & $\begin{array}{l}\text { Depressie } \\
\text { (zie Dementie en Anemie) }\end{array}$ & 0.11 & $<0.01$ \\
\hline Acute verwardheid & Hypertensie & 0.18 & $<0.000$ \\
\hline \multirow[t]{2}{*}{ Depressie } & Vallen & 0.11 & $<0.01$ \\
\hline & (zie Dementie, Gewichtsverlies, D & ydratie & \\
\hline Nierfunktiest. & (zie Anemie) & & \\
\hline Heupfraktuur & $\begin{array}{l}\text { Decubitus } \\
\text { (zie Acute Inamobilisatie) }\end{array}$ & 0.19 & $<0.000$ \\
\hline Vallen & (zie Depressie) & & \\
\hline
\end{tabular}


Decubitus

Visusstoornissen

Pneumonie

Hypertensie

Myocardinfarct (zie Dehydratie, Heupfraktuur)

(zie Gehoorstoornissen)

(zie Acute Incontinentie, CVA)

(zie CVA, Acute Verwardheid)

(zie Decompensatio cordis)

Pearson, tweezijdig.

Tabel 5.2.4 Pearson's correlaties van leeftijd en geslacht met de 28 meest voorkomende diagnoses $(n=489)$.

R p-waarde

$\begin{array}{lcc}\text { Leeftijd } & & \\ \text { Dehydratie } & 0.14 & <0.000 \\ \text { Heupfraktuur } & 0.13 & <0.000 \\ \text { Gehoorstoornis } & 0.10 & <0.01 \\ \text { Urineweginfektie } & 0.09 & =0.001 \\ \text { Obstipatie } & 0.09 & <0.01 \\ \text { CVA } & -0.08 & <0.05 \\ \text { Diabetes } & -0.08 & <0.05 \\ \text { Depressie } & -0.08 & <0.05 \\ \text { CARA } & -0.09 & <0.05 \\ \text { Verwardheid } & -0.10 & <0.01 \\ \text { Hypertensie } & -0.14 & <0.000 \\ & & \\ \text { Geslacht } & & \\ \text { Pneumonie } & 0.16 & <0.000 \\ \text { CARA } & 0.14 & <0.000 \\ \text { CVA } & 0.13 & =0.001 \\ \text { Incontinentie } & 0.07 & <0.05 \\ \text { Visusstoornis } & -0.08 & <0.05 \\ \text { Heupfraktuur } & -0.09 & <0.05 \\ \text { Urineweginfektie } & -0.13 & <0.000\end{array}$

Pearson's R, tweezijdig

*Alleen diagnoses met een significante correlatie zijn vermeld.

geldt dat de correlatie hooguit zwak te noemen is, zelfs in gevallen waarin een onderling verband voor de hand liggend is.

Wanneer diagnoses gegroepeerd worden tot diagnosegroepen volgens de systematiek van de ICD-classificatie verbetert dit verband niet of nauwelijks (tabel 5.2.6). Voor een beperkt aantal diagnosegroepen wordt een zwakke correlatie gevonden. De overige bereiken in het geheel geen significantie. 
Tabel 5.2.5 Correlaties van de 28 meest voorkomende diagnoses met funktioneringselementen bij opname. Alleen significante correlaties worden vermeld. $\mathrm{N}=489$.

\begin{tabular}{|c|c|c|c|c|c|c|}
\hline & \multicolumn{2}{|l|}{ ADL } & \multicolumn{2}{|c|}{ Mobiliteit } & \multicolumn{2}{|c|}{ Incontinentie } \\
\hline & $\mathbf{R}$ & p-waarde & $\mathrm{R}$ & p-waarde & $\mathbf{R}$ & p-waarde \\
\hline Verzorgings- & & & & & & \\
\hline $\begin{array}{l}\text { problematiek } \\
\text { Immobilisatie }\end{array}$ & $\begin{array}{l}0.16 \\
0.23\end{array}$ & $\begin{array}{l}<0.000 \\
<0.000\end{array}$ & $\begin{array}{l}0.14 \\
0.26\end{array}$ & $\begin{array}{l}<0.01 \\
<0.000\end{array}$ & $\begin{array}{l}0.14 \\
0.18\end{array}$ & $\begin{array}{l}<0.01 \\
<0.000\end{array}$ \\
\hline Dehydratie & 0.10 & $<0.05$ & 0.13 & $<0.05$ & 0.11 & $<0.05$ \\
\hline Heupfraktuur & 0.15 & $<0.000$ & 0.11 & $<0.05$ & & \\
\hline Decubitus & 0.17 & $<0.000$ & & & 0.12 & $<0.05$ \\
\hline Urineweginfektie & 0.11 & $<0.010$ & & & 0.15 & $=0.001$ \\
\hline Dementie & 0.13 & $<0.01$ & & & 0.18 & $<0.000$ \\
\hline Incontinentie & & & 0.19 & $<0.000$ & 0.38 & $<0.000$ \\
\hline Loopstoornis & & & 0.13 & $<0.01$ & 0.16 & $=0.001$ \\
\hline Gewichtsverlies & 0.19 & $<0.000$ & & & & \\
\hline Pneumonie & 0.14 & $=0.001$ & & & & \\
\hline Depressie & 0.13 & $<0.01$ & & & & \\
\hline CVA & & & 0.09 & $=0.05$ & & \\
\hline Cognitieve stoornis & & & 0.09 & $<0.05$ & & \\
\hline CARA & & & & & 0.12 & $<0.01$ \\
\hline
\end{tabular}

Pearson, tweezijdig.

Geen significante correlaties

Obstipatie

Gehoorstoornis

Diabetes

Decompensatio cordis

Recidiverend vallen

Verwardheid

B6 deficiëntie

Anemie

Atriumfibrilleren

Visusstoornis

Hypertensie

Infarct

Nierfunktiestoornis 
Tabel 5.2.6 De Pearson-correlatie tussen funktioneringselementen en diagnosegroepen bij opname *.

\begin{tabular}{lllllll}
\hline Diagnosegroep & A.DL & & & \multicolumn{2}{l}{ Mobiliteit } \\
\cline { 2 - 3 } & $\mathbf{R}$ & p-waarde & & $\mathbf{R}$ & p-waarde \\
\hline Psychische stoornis & & & & & \\
Neurologische afwijking & 0.13 & $=0.001$ & & 0.13 & $<0.000$ \\
Afwijking bewegingsapparaat & 0.17 & $<0.000$ & & 0.22 & $<0.000$ \\
Urologische afwijking & 0.11 & $<0.01$ & & 0.12 & $<0.000$ \\
Ongevallen & 0.19 & $<0.000$ & & 0.19 & $<0.000$ \\
\hline
\end{tabular}

- Overige diagnosegroepen geen correlatie $(R \leq 0.10)$

\subsection{Diagnoseclusters}

Zoals vermeld zijn er 28 diagnoses/problemen met een frequentie van tenminste $5 \%$ in de onderzochte patiëntenpopulatie. In tabel 5.2.2 werd de frequentie van voorkomen van deze diagnoses vermeld. $\mathrm{Bij} 5 \%$ van de patiënten $(n=23)$ wordt geen van deze diagnoses gesteld, terwijl bij $10 \%$ van de patiënten 6 of meer van deze diagnoses tegelijkertijd voorkomen. Gemiddeld worden 3.3 van deze diagnoses per patiënt gesteld, ofwel vormen zij $58 \%$ van de totale diagnoseload. Vanzelfsprekend is het niet zo dat de kombinatie - het tegelijkertijd aanwezig zijn van één of meer van de 28 meest voorkomende diagnoses - volkomen willekeurig is.

Omdat het zeer bewerkelijk en bovendien onoverzichtelijk is steeds alle gegevens voor de 28 meest voorkomende afzonderlijke diagnoses te geven is getracht - ondanks de lage korrelaties - met behulp van een clusteranalyse een aantal samengestelde clusters van diagnoses te vinden. De eerder gebruikte "gewone" korrelatie-efficient is minder geschikt om als basis voor deze clusteranalyse te dienen. Meer geschikt is de associatiemaat van Jaccard. Deze coëfficient geeft weer in welke mate twee verschijnselen samengaan, zonder acht te slaan op de mate waarin ze niet tesamen voorkomen. Het niet samengaan van twee verschijnselen is gewoonlijk een weinig interessant gegeven. Een voorbeeld: zoals eerder gesteld bestaat er een samenhang tussen visusen gehoorstoornissen. 
De bijbehorende tabel is de volgende:

\begin{tabular}{|c|c|c|c|c|}
\hline & & Vis & missen & Totaal \\
\hline & & + & - & \\
\hline Gehoorstoornissen & + & $\begin{array}{l}13 \\
\text { (a) }\end{array}$ & $\begin{array}{r}37 \\
\text { (b) }\end{array}$ & 50 \\
\hline & - & $\begin{array}{l}16 \\
\text { (c) }\end{array}$ & $\begin{array}{r}423 \\
\text { (d) }\end{array}$ & 439 \\
\hline Totaal & & 29 & 460 & 489 \\
\hline
\end{tabular}

Voor de Jaccard index geldt de volgende formule:

$$
\mathrm{J}=\frac{a}{a+b+c}=\frac{13}{66}=0.20
$$

Bij de op de Jaccard-maat gebaseerde clusteranalyse wordt steeds nagegaan welke kombinatie van diagnoses de hoogste gemiddelde Jaccard heeft. Daarna worden achtereenvolgens nieuwe clusters met lagere gemiddelden gevormd. Ook kunnen clusters door samenvoeging op deze wijze weer nieuwe clusters vormen. Bij de beoordeling van het uiteindelijke aantal relevante clusters spelen de volgende overwegingen een rol:

- er moet een laagste gemiddelde Jaccard gekozen worden, die als ondergrens fungeert. Gezien de lage onderlinge korrelaties in de onderhavige situatie is het niveau bepaald op 0.10 ;

- getracht moet worden in zo weinig mogelijk clusters zoveel mogelijk diagnoses onder te brengen, waarbij zo min mogelijk afzonderlijke diagnoses overblijven: Bij een ondergrens van 0.10 vallen 22 diagnoses in 8 clusters en resteren slechts 6 losse diagnoses;

- nagegaan dient te worden of de clusters inhoudelijk zinvol geïnterpreteerd kunnen worden.

De uitkomst van de cluseranalyse met de associatiemaat van Jaccard gehanteerd konform bovenstaande overwegingen is weergegeven in tabel 5.3.1. 
Tabel 5.3.1 Uitkomst van de Jaccard-analyse. De clusters: indeling en frequentie van voorkomen (aantal patiënten dat een of meerdere diagnoses uit het cluster heeft).

\begin{tabular}{|c|c|c|c|c|c|}
\hline $\begin{array}{l}\text { Cluster } \\
\mathrm{nr}\end{array}$ & Diagnoses in cluster & Naam cluster & $\begin{array}{l}\text { Aantal } \\
\text { patiënten }\end{array}$ & $\%$ & $\begin{array}{l}\text { Gem.Jaccard } \\
\text { Coefficiënt }\end{array}$ \\
\hline I & $\begin{array}{l}\text { Cognitieve stoornis/ } \\
\text { Verzorgingsproblematiek/ } \\
\text { Dementie/ } \\
\text { Acute Incontinentie/ } \\
\text { Acute Immobilisatie }\end{array}$ & $\begin{array}{l}\text { Geriatrisch* } \\
\text { Complex }\end{array}$ & 307 & 65 & 0.11 \\
\hline II & $\begin{array}{l}\text { Atrium Fibrilleren/ } \\
\text { Decompensatio Cordis/ } \\
\text { Myocardinfarct }\end{array}$ & Cardiaal & 119 & 25 & 0.12 \\
\hline III & $\begin{array}{l}\text { Visusstoornis/ } \\
\text { Gehoorstoornis/ } \\
\text { Obstipatie }\end{array}$ & Visus & 108 & 23 & 0.11 \\
\hline IV & $\begin{array}{l}\text { Diabetes/ } \\
\text { Dehydratie/ } \\
\text { Urineweginfekties }\end{array}$ & Diabetes & 173 & 37 & 010 \\
\hline $\mathrm{v}$ & $\begin{array}{l}\text { Heupfrakturen/ } \\
\text { Decubitus }\end{array}$ & Heupfraktuur & 51 & 11 & 0.14 \\
\hline VI & $\begin{array}{l}\text { Hypertensie/ } \\
\text { Verwardheid }\end{array}$ & Hypertensie & 54 & 11 & 0.13 \\
\hline VII & $\begin{array}{l}\text { Gewichtsverlies/ } \\
\text { Depressie }\end{array}$ & Depressie & 69 & 15 & 0.11 \\
\hline VIII & $\begin{array}{l}\text { Anemie/ } \\
\text { B6 deficiëntie }\end{array}$ & Anemie & 103 & 22 & 0.10 \\
\hline
\end{tabular}

- Aantal patiënten met tenminste é́n element; $n=307$

Aantal patiënten met tenminste twee elementen; $n=131$

Diagnoses/problemen die niet tot een cluster behoren

\begin{tabular}{lllr}
\hline & Diagnose & Patiënten & $\%$ \\
\hline 1. & Loopstoornissen & 49 & 10 \\
2. & Vallen & 29 & 6 \\
3. & Nierfunktiestoornis & 30 & 6 \\
4. & CARA & 54 & 11 \\
5. & CVA & 44 & 9 \\
6. & Pneumonie & 28 & 6 \\
\hline
\end{tabular}


De niet geclusterde diagnoses komen 233 keer voor (d.w.z. $8 \%$ van de totale diagnoseload). Logischerwijs wordt per patiënt doorgaans slechts éen van deze diagnoses gesteld (zie tabel 5.3.2).

Tabel 5.3i.2 Frequentieverdeling van de zes niet geclusterde diagnoses: aantal niet geclusterde diagnoses per patiënt, percentage patiënten per frequentiegroep. Totaal aantal patiënten: 489. Gemiddeld aantal niet geclusterde diagnoses, per patiënt.

\begin{tabular}{llr}
\hline $\begin{array}{l}\text { Aantal } \\
\text { diagnoses }\end{array}$ & $\begin{array}{l}\text { Aantal } \\
\text { patiënten }\end{array}$ & $\%$ \\
\hline 0 & 301 & 62 \\
1 & 147 & 30 \\
2 & 37 & 8 \\
3 & 4 & 1 \\
Totaal & $\overline{489}$ & $\overline{100}$ \\
\hline
\end{tabular}

Gemiddelde per patiënt: 0,5 diagnoses $(S D 0,7)$

De 8 zogenaamde clusters vormen $37 \%$ van de totale diagnoseload. De frequentie verdeling is weergegeven in tabel 5.3.3.

Tabel 5.3.3 Frequentie verdeling van het aantal geclusterde diagnoses per patiënt, percentage patiënten per frequentiegroep. Aantal clusters: 8 . Aantal patiënten: 489 .

\begin{tabular}{lcr}
\hline $\begin{array}{l}\text { Aantal } \\
\text { diagnoses }\end{array}$ & $\begin{array}{l}\text { Aantal } \\
\text { patiënten }\end{array}$ & $\%$ \\
\hline 0 & 35 & 7 \\
1 & 115 & 23 \\
2 & 177 & 36 \\
3 & 107 & 22 \\
4 & 44 & 9 \\
5 & 9 & 2 \\
6 & 2 & 1 \\
Totaal & \multicolumn{4}{|c|}{} & 100 \\
\hline
\end{tabular}

Gemiddelde per patiēnt: 2,09 clusters (SD 1,6)

Hieruit blijkt dat gemiddeld per patiënt tenminste twee van deze clusters aanwezig zijn. Slechts $7 \%$ van de patiënten heeft geen diagnose behorend tot één van de clusters.

Van belang voor de verdere interpretatie is dat, weliswaar met behulp van deze clusters meer inzicht verkregen kan worden in de structuur van de problematiek die voorkomt bij de onderzochte patiënten, maar dat de associatiemaat als zodanig laag is. 
De reden van samenhang binnen de verschillende clusters kan uiteraard uiteenlopen. Hierop wordt per cluster kort ingegaan.

\section{Cluster I Cognitieve stoornissen/Acute immobilisatie/Acute incontinentie/Verzorgingsproblematiek/Dementiesyndroom.}

Hierin zijn een aantal diagnoses/problemen terug te vinden, waarvan waarschijnlijk meer dan in andere clusters het gemeenschappelijk voorkomen karakteristiek is voor de "klassieke" geriatrische patiënt. Het betreft cognitieve stoornissen, dementiesyndroom, verzorgingsproblematiek, acute incontinentie en acute immobilisatie. Een of meer elementen van dit cluster komen voor bij 307 patiënten ofwel bij bijna tweederde van de patiënten komt één van deze aspecten voor, terwijl ruim één kwart van de patiënten minstens twee van genoemde diagnoses/problemen heeft.

Bij de verdere bespreking zal dit cluster aangeduid worden als het "Geriatrisch Complex".

\section{Cluster II Atriumfibrilleren/Decompensatio cordis/Myocardinfarct.}

De relatie tussen atriumfibrilleren, decompensatio cordis en myocardinfarcten is éénduidig. Deze aandoeningen zijn te beschouwen als verschillende met elkaar samenhangende verschijnselen van éénzelfde problematiek: hartvaatziekte. Elementen van dit cluster komen voor bij 119 patiënten, of wel 25\% van de populatie.

\section{Cluster III Visusstoornissen/Gehoorstoornissen/Obstipatie.}

Het samengaan van visusstoornissen, gehoorstoornissen en obstipatie is niet goed verklaarbaar. Een gemeenschappelijke faktor vormt het relatief grote belang van autoanamnestische gegevens bij deze diagnoses. Bij patiënten die niet (kunnen) klagen zullen deze problemen frequent gemist worden.

Patiënten die wel in staat zijn tot het geven van een adequate anamnese zijn mogelijk geneigd op meerdere vlakken ongemakken en beperkingen te verwoorden. In aantallen gaat het om 108 patiënten, ofwel $23 \%$.

\section{Cluster IV Diabetes/Urineweginfekties/Dehydratie.}

De relatie tussen diabetes en urineweginfekties is klinisch goed bekend. Osmotische diurese bij een verhoogd bloedsuikergehalte kan de samenhang met dehydratie verklaren.

Problematiek behorend tot dit cluster komt voor bij 173 patiënten (37\%). 
Dit cluster omvat heupfrakturen en decubitus. Verhoudingsgewijs gaat het om een klein aantal patiënten, nl. $51(11 \%)$. De klinische betekenis van deze entiteit kan gezocht worden in het feit dat de bedlegerigheid ten gevolge van een heupfraktuur bij de onderzochte patiëntengroep relatief frequent decubitus tot gevolg heeft. Een alternatieve verklaring vomt de mogelijkheid dat speciaal bij patiënten met een heupfraktuur, bij wie decubitus ontstaat of aanwezig is, medebehandeling in het kader van het FGB wordt gevraagd.

Opvallend in de analyse is de veel lagere coëfficient die gevonden wordt in de relatie tussen CVA en decubitus. Mogelijke verklaring hiervoor is een meer efficiënte decubitusbestrijding bij het CVA of een geringer verwijspercentage van CVA patiënten met decubitus naar het FGB.

\section{Cluster VI Hypertensie/Acute verwardheid.}

Het samengaan van hypertensie met acute verwardheid is op meerdere wijzen verklaarbaar. Lang bestaande hypertensie kan dusdanige cerebro vasculaire beschadiging vercorzaken, dat (onder stress-situaties) gemakkelijker delirante beelden worden geluxeerd (Jones e.a., 1978). Een alternatieve verklaring kan zijn dat de medicatie die gehanteerd wordt bij behandeling van hypertensie (o.a. $\beta$-blokker, diuretica e.d.) het risico voor het ontstaan van acute verwardheid heeft verhoogd.

Ook hier gaat het om een relatief klein aantal patiënten: 54 (11\%).

\section{Cluster VII Gewichtsverlies/Depressie.}

De relatie tussen gewichtsverlies en depressiviteit kan betekenen dat er relatief frequent sprake is van vitale depressies. Mogelijk dat juist deze groep depressieve patiënten eerder dan andere voor behandeling wordt opgenomen in het ziekenhuis, danwel dat geriatrische begeleiding van dergelijke hoogbejaarden noodzakelijk wordt geacht. Het totale aantal patiënten bedraagt $69(15 \%)$.

\section{Cluster VIII Anemie/Vitamine B6 deficiëntie.}

Hieronder vallen anemie en vitamine B6 deficiëntie. Alhoewel een causale relatie tussen beide diagnoses kan worden gelegd is het niet waarschijnlijk dat dit de voornaamste verklaring vormt voor de samenhang. Vrijwel alle patiënten bij wie een verlaagd vitamine $B 6$ geconstateerd is zijn gedurende opname adequaat gesuppleerd, terwijl slechts bij een beperkt aantal de anemie (mede hierdoor) is verdwenen. In zoverre beide een afspiegeling kunnen vormen van de voedingstoestand van de patiënt is een zekere paralelliteit verklaarbaar. Het veelvuldig voorkomen van vitamine $B 6$-deficiëntie kan mede berusten op het feit dat bepaling van vitamines net als bepaling van de 
schildklierfunktie bij geriatrische patiënten veelvuldig voorkomt. Het totaal aantal patiënten in dit cluster bedraagt $103(22 \%)$.

\subsection{Het Geriatrisch Complex en het funktioneren bij opname.}

De vraag in hoeverre de geformuleerde diagnoses en problemen in cluster I, het Geriatrisch Complex, corresponderen met het funktioneren zoals gemeten in de schalen voor ADL, mobiliteit en incontinentie bij, opname is onderzocht. Uit de analyse blijkt dat er zowel een kwalitatieve invloed (wel of niet aanwezig) als een kwantitatieve invloed bestaat (één of meerdere elementen aanwezig); zie tabel 5.4.1.

Tabel 5.4.1 Relatie van funktioneringselementen bij opname met het aantal diagnoses van het Geriatrisch Complex. N $=489$.

\begin{tabular}{|c|c|c|c|c|c|}
\hline \multirow{2}{*}{$\begin{array}{l}\text { Funktioneringselement } \\
\text { Bij opname }\end{array}$} & \multicolumn{5}{|c|}{ Aantal diagnoses binnen het Geriatrisch Complex } \\
\hline & 0 & 01 & $\geq 2$ & Totaal & p-waarde \\
\hline \multicolumn{6}{|l|}{ Bedlegerig } \\
\hline niet bedilegerig & 36 & 34 & 30 & 100 & \\
\hline bedlegerig & 31 & 39 & 31 & 100 & NS \\
\hline \multicolumn{6}{|l|}{ Catheter } \\
\hline geen catheter & 37 & 36 & 27 & 100 & \\
\hline catheter & 24 & 35 & 42 & 100 & $<0.01$ \\
\hline \multicolumn{6}{|l|}{ ADL } \\
\hline zelfstandig & 81 & 12 & 7 & 100 & \\
\hline discontinue hulp & 36 & 42 & 22 & 100 & \\
\hline continue hulp & 28 & 35 & 37 & 100 & $<0.000$ \\
\hline \multicolumn{6}{|l|}{ Mobiliteit } \\
\hline zelfstandig & 47 & 33 & 20 & 100 & \\
\hline personele hulp & 24 & 35 & 41 & 100 & $<0.000$ \\
\hline \multicolumn{6}{|l|}{ Incontinentie } \\
\hline & 58 & 28 & 14 & 100 & \\
\hline zelden & 21 & 48 & 31 & 100 & \\
\hline frequent & 15 & 37 & 48 & 100 & $<0.000$ \\
\hline
\end{tabular}

$x^{2}$

Gekonkludeerd kan worden dat alle onderzochte variabelen behalve bedlegerigheid significant (d.w.z. negatief) beïnvloed worden door de aanwezigheid van elementen uit dit cluster. Het funktioneren van geriatrische patiënten bij ziekenhuisopname lijkt gerelateerd te kunnen worden aan een relatief klein 
aantal elementen, te weten: acute immobilisatie, acute incontinentie, verzorgingsproblematiek, dementie of cognitieve stoornissen.

\subsection{Bespreking}

Uit de analyse blijkt dat de onderzochte populatie - hoogbejaard veelvuldig alleenstaand veelal reeds duidelijk zorgafhankelijk in de woonsituatie - bij opname in het ziekenhuis sterk ADL-afhankelijk is, vaak beperkt mobiel en/of incontinent. De vraag is nu welke problemen en/of diagnoses in deze populatie hiervoor verantwoordelijk zijn. Leeftijd en geslacht zijn niet van inviloed op het funktioneren. Het is voor de hand liggend te veronderstellen dat de belangrijkste diagnoses en problemen die in deze populatie voorkomen wel duidelijk van invloed zijn. Bij analyse blijkt dit noch op het niveau van afzonderlijke diagnoses, noch op het niveau van diagnosecategoriën het geval. Wanneer echter op een ander aggregatieniveau wordt bezien wat de invloed is van coïncidentie van ziekte en problemen (de Jaccard-index) blijkt dat een specifiek (en beperkt) cluster van veel voorkomende aandoeningen wel min of meer discriminerend is ten aanzien van het funktioneren. De elementen van dit cluster of zogenoemd Geriatrisch Complex zijn herkenbaar als typische voorbeelden van wat in de literatuur veelal wordt aangeduid als "geriatric giants". Duidelijk komt naar voren dat het hier niet de primair orgaanbepaalde problematiek betreft maar een vertaling in problemen van aspecten van het psychisch en sociaal funktioneren enerzijds: cognitieve stoornissen, dementiesyndroom, verzorgingsproblematiek; en funktionele beperkingen en handicaps anderzijds: immobilisatie en incontinentie.

De onderkenning van genoemde elementen als bepalend voor het verdere beloop van de patiëntencarrière vormt een belangrijk argument in de discussie over de specifieke bijdrage die de geriatrie kan leveren in de gezondheidszorg voor hoogbejaarde patiënten.

Het uitsluitend behandelen van de specifieke orgaanproblematiek heeft onvoldoende effect. Gerichte aandacht voor elementen uit het Geriatrisch Complex en daarmee voor de invloed die deze hebben op het funktioneren is evenzeer van belang, wil de "verzorgde" niet weliswaar genezen maar nog even zorgbehoeftig als bij opname blijven.

De mogelijkheid van een meer strikt onderscheid tussen "gewone ouderen" en geriatrische patiënten in termen van zorgbeleid lijkt door het identificeren van het Geriatrisch Complex aanwezig. 


\section{De situatie bij ontslag: ADL-funktioneren, mobiliteit en urine-incontinentieproblematiek}

Voor de 489 patiënten die beschreven zijn in hoofdstuk $V$ is nagegaan in welke mate ADL-funktioneren, mobiliteit en urine-incontinentieproblematiek zijn veranderd tussen het moment van opname en het moment van ontslag.

In de analyses wordt getracht een verband te leggen tussen het funktioneren bij ontslag en de volgende specifieke gegevens:

- leeftijd en geslacht

. de 28 meest voorkomende diagnoses

- ADL-funktioneren bij opname

- de mobiliteit

- incontinentieproblematiek bij opname

- woonsituatie voor opname

- mediane opnameduur

- het Geriatrisch Complex (cluster I)

- het cluster atriumfibrilleren, decompensatio cordis en myocardinfarct (cluster II)

- het cluster diabetes, dehydratie en urineweginfektie (cluster IV)

- het cluster heupfraktuur en decubitus (cluster V)

- de ontslagrichting

De keuze van de genoemde clusters is bepaald door de omvang, de mate waarin de elementen van het cluster klinisch zinvol geïnterpreteerd kunnen worden en de gevonden korrelatie tussen afzonderlijke clusterbestanddelen en funktioneringselementen. Wat omvang betreft zijn cluster I (het Geriatrisch Complex), cluster IV (diabetes e.a.) en cluster II (cardiale problematiek) het grootst. De meest inhoudelijk te interpreteren samenhang is te vinden in cluster II (cardiale problematiek).

In eerste instantie is nagegaan wat de invloed is van leeftijd en geslacht op het funktioneren bij ontslag. Vervolgens wordt voor de 28 meest voorkomende ziektebeelden nagegaan wat de relatie is met het ADL-funktioneren, de mobiliteit en incontinentie bij ontslag. Daarna worden deze ziektebeelden geclusterd volgens de clusteranalyse met index van Jaccard - in verband gebracht met deze gegevens. Middels regressie-analyse en discriminant ara- 
lyse wordt gepoogd een bepaalde rangorde aan te brengen in deze gegevens. Tenslotte wordt ingegaan op de ontslagrichting.

\subsection{Het verschil tussen opname en ontslag}

\section{ADL-funktioneren}

Bij ontslag is bij $58 \%$ van de patiënten de toestand t.o.v. opname onveranderd, $37 \%$ is verbeterd en $5 \%$ is verslechterd. Voor de licht ADL-behoeftige patiënten $(A D L=2)$ geldt dat $26 \%$ is verbeterd en $12 \%$ is versiechterd. Van de

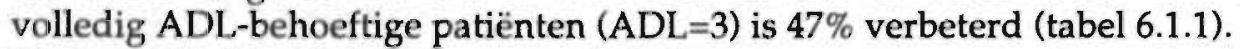

De gemiddelde ADL-score voor de hele groep op een schaal van 1 tot 3 bedraagt bij opname 2.5 en bij ontslag 2.2. Dit verschil is significant (gepaarde T-toets, $\mathrm{R}=0.54, \mathrm{p}<0.0001$ ).

Tabel 6.1.1 Het ADL-funktioneren bij opname en ontslag. $N=489$. Kruistabellen in absolute aantallen $(\mathrm{N})$ patiënten en in percentages ("\%").

\begin{tabular}{lllll}
\hline N & \multicolumn{2}{l}{ ADL bij ontslag } & \\
\cline { 2 - 4 } $\begin{array}{llll}\text { ADL } \\
\text { Bij opname }\end{array}$ & $\begin{array}{l}\text { Zelf- } \\
\text { standig }\end{array}$ & $\begin{array}{l}\text { Discontinue } \\
\text { zorg }\end{array}$ & $\begin{array}{l}\text { Continue } \\
\text { zorg }\end{array}$ & Totaal \\
\hline Zelfstandig & 33 & 6 & 1 & 40 \\
$\begin{array}{llll}\text { Discontinue zorg } \\
\text { Continue zorg }\end{array}$ & 36 & 87 & 16 & 139 \\
Totaal & 25 & 116 & 157 & 298 \\
\hline
\end{tabular}

$\%$

ADL bij ontslag

\begin{tabular}{|c|c|c|c|c|}
\hline $\begin{array}{l}\text { ADL } \\
\text { Bij opname }\end{array}$ & $\begin{array}{l}\text { Zelf- } \\
\text { standig }\end{array}$ & $\begin{array}{l}\text { Discontinue } \\
\text { zorg }\end{array}$ & $\begin{array}{l}\text { Continue } \\
\text { zorg }\end{array}$ & Totaal \\
\hline Zelfstandig & 83 & 15 & 2 & 100 \\
\hline Discontinue zorg & 26 & 62 & 12 & 100 \\
\hline Continue zorg & 8 & 39 & 53 & 100 \\
\hline Totaal & 20 & 44 & 36 & 100 \\
\hline
\end{tabular}

Ontbrekende data $n=12$

\section{Mobiliteit}

Bij ontslag is bedlegerigheid een uitzondering: $7 \%$ blijft bedlegerig, $1 \%$ wordt bedlegerig gedurende opname. 
Voor de niet bedlegerige patiënten is $70 \%$ niet belangrijk veranderd qua mobiliteit, $28 \%$ is verbeterd en $2 \%$ is verslechterd (tabel 6.1.2).

Tabel 6.1.2 Mobiliteit bij opname en ontslag: Kruistabellen in absolute aantallen $(\mathbb{N})$ patiēnten en in percentages ("\%"). Uitgesplitst naar bedlegerigheid en mobiliteit van niet-bedlegerige patiënten.

Bedlegerig*

\begin{tabular}{|c|c|c|c|}
\hline \multirow{2}{*}{$\begin{array}{l}\mathrm{N} \\
\text { Opname }\end{array}$} & \multicolumn{2}{|l|}{ Ontslag } & \multirow[b]{2}{*}{ Totaal } \\
\hline & Niet bedlegerig & Wel bedlegerig & \\
\hline Niet bedlegerig & 332. & 5 & 337 \\
\hline Wel bedlegerig & 137 & 11 & 148 \\
\hline Totaal & 469 & 16 & 485 \\
\hline
\end{tabular}

$\%$

Opname

$\begin{array}{llll}\text { Niet bedlegerig } & 99 & 1 & 100 \\ \text { Wel bedlegerig } & 93 & 7 & 100 \\ \text { Totaal } & 97 & 3 & 100\end{array}$

Niet bedlegerige patiënten: mobiliteit**

\begin{tabular}{llcl}
\hline \multirow{2}{*}{$\begin{array}{l}\text { Ontslag } \\
\text { Opname }\end{array}$} & \multicolumn{2}{l}{} \\
\cline { 2 - 3 } & Zelfstandig & Niet zelfstandig & Totaal \\
\hline Zelfstandig & 165 & 5 & 170 \\
Personele hulp & 92 & 64 & 156 \\
Totaal & 257 & 69 & 326 \\
\hline \% & & & \\
Opname & & 3 & \\
\hline Zelfstandig & 97 & 41 & 100 \\
Personele hulp & 59 & 21 & 100 \\
Totaal & 79 & & 100 \\
\hline
\end{tabular}

"ontbrekende data $n=4$; ${ }^{* *}$ ontbrekende data $n=11$ 
Tabel 6.1.3 Mobiliteit bij opname en ontslag: Kruistabellen in absolute aantallen (N) patiënten en in percentages ("\%"). Uitgesplitst naar cathetergebruik en incontinentie van patiënten.

Cathetergebruik*

\begin{tabular}{llll}
\hline & \multicolumn{2}{l}{ Ontslag } & \\
\cline { 2 - 3 } Opname & Geen catheter & Wel catheter & Totaal \\
\hline Geen catheter & 369 & 15 & 384 \\
Wel catheter & 75 & 26 & 101 \\
Totaal & 444 & 41 & 485 \\
\hline
\end{tabular}

$\%$

Opname

$\begin{array}{lrrr}\text { Geen catheter } & 96 & 4 & 100 \\ \text { Wel catheter } & 74 & 26 & 100 \\ \text { Totaal } & 92 & 8 & 100\end{array}$

Patiënten zonder catheter: incontinentie ${ }^{\text {t** }}$

\begin{tabular}{lllll}
\hline & \multicolumn{2}{c}{ Ontslag } & & \\
\cline { 2 - 4 } Opname & Niet & Zelden & Frequent & Totaal \\
\hline Niet & 162 & 11 & 5 & 178 \\
Zelden & 34 & 50 & 11 & 95 \\
Frequent & 12 & 34 & 45 & 91 \\
Totaal & 208 & 95 & 61 & 364 \\
\hline
\end{tabular}

$\%$

Opname

\begin{tabular}{lrrrr}
\hline Niet & 91 & 6 & 3 & 100 \\
Zelden & 36 & 53 & 11 & 100 \\
Frequent & 11 & 38 & 49 & 100 \\
Totaal & 57 & 26 & 17 & 100 \\
\hline
\end{tabular}

* ontbrekende data $n=4 ; * *$ ontbrekende data $n=20$ 
De gemiddelde mobiliteitsscore van de niet-bedlegerige patiënten op een schaal van 1 tot 2 is bij opname 1.5 en bij ontslag 1.2 (gepaarde T-toets, $\mathrm{R}=0.47, \mathrm{p}<0.0001$.

\section{Urine-incontinentie}

Bij driekwart van de patiënten die bij opname een urinecatheter hebben (gekregen) kan de catheter worden verwijderd. Bij $4 \%$ van de overige patiënten wordt alsnog een catheter ingebracht, zodat bij ontslag $8 \%$ van de patiënten een catheter heeft (in tweederde van de gevallen een suprapubische catheter).

Van de patiënten die bij opname geen catheter hebben blijft de incontinentieproblematiek voor $71 \%$ ongewijzigd, $22 \%$ verbetert en $7 \%$ verslechtert. Van de groep patiënten die bij opname slechts lichte incontinentieproblematiek hebben, verbetert $36 \%$ en verslechtert $12 \%$. Van de patiënten die bij opname vrijwel volledig incontinent zịnn verbetert $51 \%$ (tabel 6.1.3).

De incontinentiescore voor patiënten zonder catheter op een schaal van 1 tot 3 daalt van 1.8 bij opname tot 1.6 bij ontslag (gepaarde $\mathrm{T}$-toets, $\mathrm{R}=0.68$, $\mathrm{p}<0.0001$ ).

\subsection{Leeftijd en geslacht in relatie tot het funktioneren bij ontslag}

Leeftijd en geslacht zijn niet beïnvloedbare faktoren, maar zijn wel mede-geanalyseerd om na te gaan in hoeverre de relatief grote leeftijdsspreiding en / of de aanwezigheid van meer personen van het vrouwelijk geslacht op zich van invloed zijn op het funktioneren. Gebruik is gemaakt van een Anova-variantie analyse techniek. Hiermee is onderzocht in hoeverre er een significante relatie bestaat tussen bedlegerigheid, cathetergebruik, ADL-funktioneren, incontinentie en mobiliteit enerzijds en leeftijd en geslacht anderzijds.

Het blijkt dat geen significante verschillen gevonden worden voor bedlegerigheid, cathetergebruik, ADL-funktioneren of mobiliteit op het moment van ontslag, gelet op leeftijd en geslacht.

Alleen voor incontinentie van urine bij ontslag geldt dat in de groep ernstig incontinente patiënten significant meer mannen voorkomen dan in de groep niet of zelden incontinente patiënten $(p<0.01)$.

Omdat bij opname een dergelijk verschil niet wordt gevonden, kan verondersteld worden dat bij vrouwen vaker geheel of ten dele reversibele c.q. behandelbare vormen van incontinentie worden aangetroffen. Het verder ontbreken van een invloed van leeftijd of geslacht op de onderzochte parameters geeft aan dat in de onderzochte groep geriatrische patiënten de verschillen in leeftijd en geslacht, de verschillen in uitkomsten met betrekking tot het funktioneren bij ontslag niet verklaren. 
Voor de behandelstrategie heeft dit als uitvloeisel dat noch de leeftijd, noch het geslacht een faktor is walarmee in het bijzonder rekening moet worden gehouden.

\subsection{De relatie tussen de diagnoses en het funktioneren bij ontslag}

\section{Bedlegerigheid}

Voor de 28 meest voorkomende diagnoses - voorkomend bij tenminste $5 \%$ van de patiënten - is middels Chi-kwadraat toetsen eveneens nagegaan wat de relatie is met het funktioneren bij ontslag (tabel 6.3.1).

Voor de totale onderzochte populatie $(n=489)$ geldt dat $3 \%(n=16)$ bedlegerig is bij ontslag (zie ook hoofdstuk 5). Voor de afzonderlijke diagnoses varieert dit percentage tussen 0 en $7 \%$ met uitzondering van patiënten met een CVA: $9 \%(n=4)$ en een pneumonie: $14 \%(n=4)$.

In geval van patiënten met een CVA zal de hierdoor veroorzaakte handicap of beperking de verklaring zijn. Voor de patiënten met een pneumonie geldt mogelijk dat pneumoniën in deze patiëntencategorie enerzijds vaak zeer ernstig verlopen en anderzijds veelal een komplikatie zijn van uitgebreide comorbiditeit. Overigens moet bij dit laatste opgemerkt worden dat in de Jaccard analyse geen specifieke relatie van pneumonie met andere diagnoses wordt gevonden, zodat het een opzichzelfstaand fenomeen is of - meer waarschijnlijk - een weinig specifiek probleem.

Met inachtneming van bovengenoemde twee uitzonderingen luidt de konklusie dat de afzonderlijke diagnoses geen specifieke relatie hebben met bedlegerigheid bij ontslag en derhalve in therapeutisch opzicht geen absolute belemmering vormen om patiënten te mobiliseren. Een restriktie die overigens geldt voor alle resultaten beschreven in dit hoofdstuk is dat dit geldt voor patiënten die niet overlijden gedurende opname.

\section{Catheters}

Het al dan niet hebben van een urinecatheter bij ontslag (tabel 6.3.2) heeft in de onderzochte populatie een significante relatie met 3 van de 28 diagnoses, te weten: acute immobilisatie, decubitus en een heupfraktuur.

Ook hier geldt dat het merendeel van de diagnoses geen relatie heeft met het hebben van een catheter bij ontslag. 
Tabel 6.3.1 Diagnoses en bedlegerigheid bij opname en bij ontslag. Diagnoses in volgorde van frequentie van aantallen patiënten per diagnose. $n=489$. Alle getallen: percentages.

\begin{tabular}{|c|c|c|c|c|c|}
\hline $\begin{array}{l}\text { Significante } \\
\text { diagnoses. }\end{array}$ & & $\begin{array}{l}\text { Bedlegerig } \\
\text { opname }\end{array}$ & p-waarde & $\begin{array}{l}\text { Bedlegerig } \\
\text { ontslag. }\end{array}$ & p-waarde \\
\hline Totale populatie & & 31 & & 3 & \\
\hline Anemie & + & $\begin{array}{l}28 \\
43\end{array}$ & $<0.01$ & $\begin{array}{l}3 \\
5\end{array}$ & NS \\
\hline $\begin{array}{l}\text { Immobilisatie } \\
\text { (acuut) }\end{array}$ & + & $\begin{array}{l}27 \\
51\end{array}$ & $<0.001$ & $\begin{array}{l}3 \\
7\end{array}$ & NS \\
\hline Dehydratie & - & $\begin{array}{l}28 \\
48\end{array}$ & $<0.01$ & $\begin{array}{l}3 \\
5\end{array}$ & NS \\
\hline Gewichtsverlies & - & $\begin{array}{r}33 \\
9\end{array}$ & $<0.001$ & $\begin{array}{l}3 \\
2\end{array}$ & NS \\
\hline CVA & - & $\begin{array}{l}30 \\
39\end{array}$ & NS & $\begin{array}{l}3 \\
9\end{array}$ & $<0.05$ \\
\hline Nierf.stoornissen & - & $\begin{array}{l}29 \\
60\end{array}$ & $<0.001$ & $\begin{array}{l}3 \\
7\end{array}$ & NS \\
\hline Heupfraktuur & - & $\begin{array}{l}28 \\
15\end{array}$ & $<0.000$ & $\begin{array}{l}3 \\
3\end{array}$ & NS \\
\hline Rec. vallen & - & $\begin{array}{l}32 \\
14\end{array}$ & $<0.05$ & $\begin{array}{l}3 \\
3\end{array}$ & NS \\
\hline Decubitus & - & $\begin{array}{l}28 \\
83\end{array}$ & $<0.000$ & $\begin{array}{l}3 \\
7\end{array}$ & NS \\
\hline Pneumonie & + & $\begin{array}{l}30 \\
50\end{array}$ & $<0.05$ & $\begin{array}{r}3 \\
14\end{array}$ & $<0.001$ \\
\hline Verzorgingsprobl. & + & $\begin{array}{l}31 \\
29\end{array}$ & NS & $\begin{array}{l}4 \\
3\end{array}$ & NS \\
\hline Dementie & + & $\begin{array}{l}32 \\
29\end{array}$ & NS & $\begin{array}{l}3 \\
4\end{array}$ & NS \\
\hline $\begin{array}{l}\text { Incontinentie } \\
\text { (acuut) }\end{array}$ & + & $\begin{array}{l}30 \\
32\end{array}$ & NS & $\begin{array}{l}3 \\
6\end{array}$ & NS \\
\hline Diabetes & + & $\begin{array}{l}30 \\
33\end{array}$ & NS & $\begin{array}{l}3 \\
5\end{array}$ & NS \\
\hline
\end{tabular}


Vervolg tabel 6.3.1

\begin{tabular}{|c|c|c|c|c|c|}
\hline $\begin{array}{l}\text { Niet significante } \\
\text { Diagnoses }\end{array}$ & & $\begin{array}{l}\text { Bedlegerig } \\
\text { opname }\end{array}$ & p-waarde & $\begin{array}{l}\text { Bedlegerig } \\
\text { ontslag }\end{array}$ & p-waarde \\
\hline Dec.cordis & $\begin{array}{l}- \\
+\end{array}$ & $\begin{array}{l}31 \\
31\end{array}$ & NS & $\begin{array}{l}3 \\
4\end{array}$ & NS \\
\hline Urineweginfektie & $\begin{array}{l}- \\
+\end{array}$ & $\begin{array}{l}30 \\
38\end{array}$ & NS & $\begin{array}{l}4 \\
0\end{array}$ & NS \\
\hline Obstipatie & - & $\begin{array}{l}31 \\
29\end{array}$ & NS & $\begin{array}{l}3 \\
4\end{array}$ & NS \\
\hline Atriumfibrilleren & $\begin{array}{l}- \\
+\end{array}$ & $\begin{array}{l}31 \\
28\end{array}$ & NS & $\begin{array}{l}3 \\
3\end{array}$ & NS \\
\hline CARA & $\begin{array}{l}- \\
+\end{array}$ & $\begin{array}{l}32 \\
23\end{array}$ & NS & $\begin{array}{l}4 \\
0\end{array}$ & NS \\
\hline Cogn.stoornissen & + & $\begin{array}{l}31 \\
29\end{array}$ & NS & $\begin{array}{l}3 \\
2\end{array}$ & NS \\
\hline Gehoorst. & + & $\begin{array}{l}30 \\
42\end{array}$ & NS & $\begin{array}{l}3 \\
4\end{array}$ & NS \\
\hline Loopstoornissen & + & $\begin{array}{l}30 \\
41\end{array}$ & NS & $\begin{array}{l}3 \\
6\end{array}$ & NS \\
\hline B6 deficiëntie & + & $\begin{array}{l}31 \\
32\end{array}$ & NS & $\begin{array}{l}4 \\
0\end{array}$ & NS \\
\hline $\begin{array}{l}\text { Verwardheid } \\
\text { (acuut) }\end{array}$ & $\begin{array}{l}- \\
+\end{array}$ & $\begin{array}{l}31 \\
26\end{array}$ & NS & $\begin{array}{l}3 \\
3\end{array}$ & NS \\
\hline Depressie & - & $\begin{array}{l}31 \\
29\end{array}$ & NS & $\begin{array}{l}3 \\
0\end{array}$ & NS \\
\hline Visusstoornissen & + & $\begin{array}{l}30 \\
38\end{array}$ & NS & $\begin{array}{l}3 \\
0\end{array}$ & NS \\
\hline Hypertensie & + & $\begin{array}{l}30 \\
41\end{array}$ & NS & $\begin{array}{l}3 \\
0\end{array}$ & NS \\
\hline Myocard-infarct & + & $\begin{array}{l}31 \\
23\end{array}$ & NS & $\begin{array}{l}3 \\
0\end{array}$ & NS \\
\hline
\end{tabular}

$x^{2}$ 
Tabei 6.3.2 Diagnoses en cathetergebruik bij opname en bij ontslag. Alleen significante diagnoses in volgorde van frequentie van aantallen patiënten per diagnose, $n=489$. Alle getallen: percentages.

\begin{tabular}{|c|c|c|c|c|c|}
\hline $\begin{array}{l}\text { Significante } \\
\text { Diagnoses }\end{array}$ & & $\begin{array}{l}\text { Catheter } \\
\text { opname }\end{array}$ & p-waarde & $\begin{array}{l}\text { Catheter } \\
\text { ontslag }\end{array}$ & p-waarde \\
\hline Totale populatie & & 21 & & 8 & \\
\hline $\begin{array}{l}\text { Incontinentie } \\
\text { (acuut) }\end{array}$ & + & $\begin{array}{l}19 \\
29\end{array}$ & $<0.05$ & $\begin{array}{l}8 \\
9\end{array}$ & NS \\
\hline $\begin{array}{l}\text { Immobilisatie } \\
\text { (acuut) }\end{array}$ & + & $\begin{array}{l}17 \\
43\end{array}$ & $<0.001$ & $\begin{array}{r}6 \\
20\end{array}$ & $<0.0001$ \\
\hline Urineweginfektie & + & $\begin{array}{l}19 \\
31\end{array}$ & $<0.05$ & $\begin{array}{r}8 \\
11\end{array}$ & NS \\
\hline Dehydratie & $\begin{array}{l}- \\
+\end{array}$ & $\begin{array}{l}19 \\
30\end{array}$ & $=0.05$ & $\begin{array}{r}7 \\
15\end{array}$ & NS \\
\hline Gewichtsverlies & + & $\begin{array}{r}22 \\
6\end{array}$ & $=0.01$ & $\begin{array}{l}9 \\
4\end{array}$ & NS \\
\hline Nierf.stoomissen & + & $\begin{array}{l}20 \\
40\end{array}$ & $<0.01$ & $\begin{array}{l}9 \\
7\end{array}$ & NS \\
\hline Heupfraktuur & $\overline{+}$ & $\begin{array}{l}20 \\
40\end{array}$ & $<0.01$ & $\begin{array}{r}7 \\
20\end{array}$ & $<0.05$ \\
\hline Decubitus & + & $\begin{array}{l}19 \\
52\end{array}$ & $<0.001$ & $\begin{array}{r}7 \\
28\end{array}$ & $<0,0001$ \\
\hline Pneumonie & + & $\begin{array}{l}20 \\
36\end{array}$ & $<0.05$ & $\begin{array}{r}8 \\
11\end{array}$ & NS \\
\hline
\end{tabular}

$x^{2}$.

De verklaring voor de wel gevonden relatie is waarschijnlijk verzorgingstechnisch: het betreft steeds patiënten bij wie de mobiliteit duidelijk beperkt is.

\section{ADL-funktioneren}

De relatie tussen het ADL-funktioneren bij ontslag en de verschillende diagnoses is meer uitgesproken (tabel 6.3.3). Van de 28 diagnoses hebben er 9 een significante relatie. In 8 gevallen is dit een negatieve invloed, éénmaal patiënten met CARA - is de relatie positief. 
Tabel 6.3.3 Diagnoses en ADL-funktioneren bij opname en bij ontslag. Alleen significante diagnoses in volgorde van frequentie van aantallen patiënten per diagnose. $n=384$. Alle getallen: percentages.

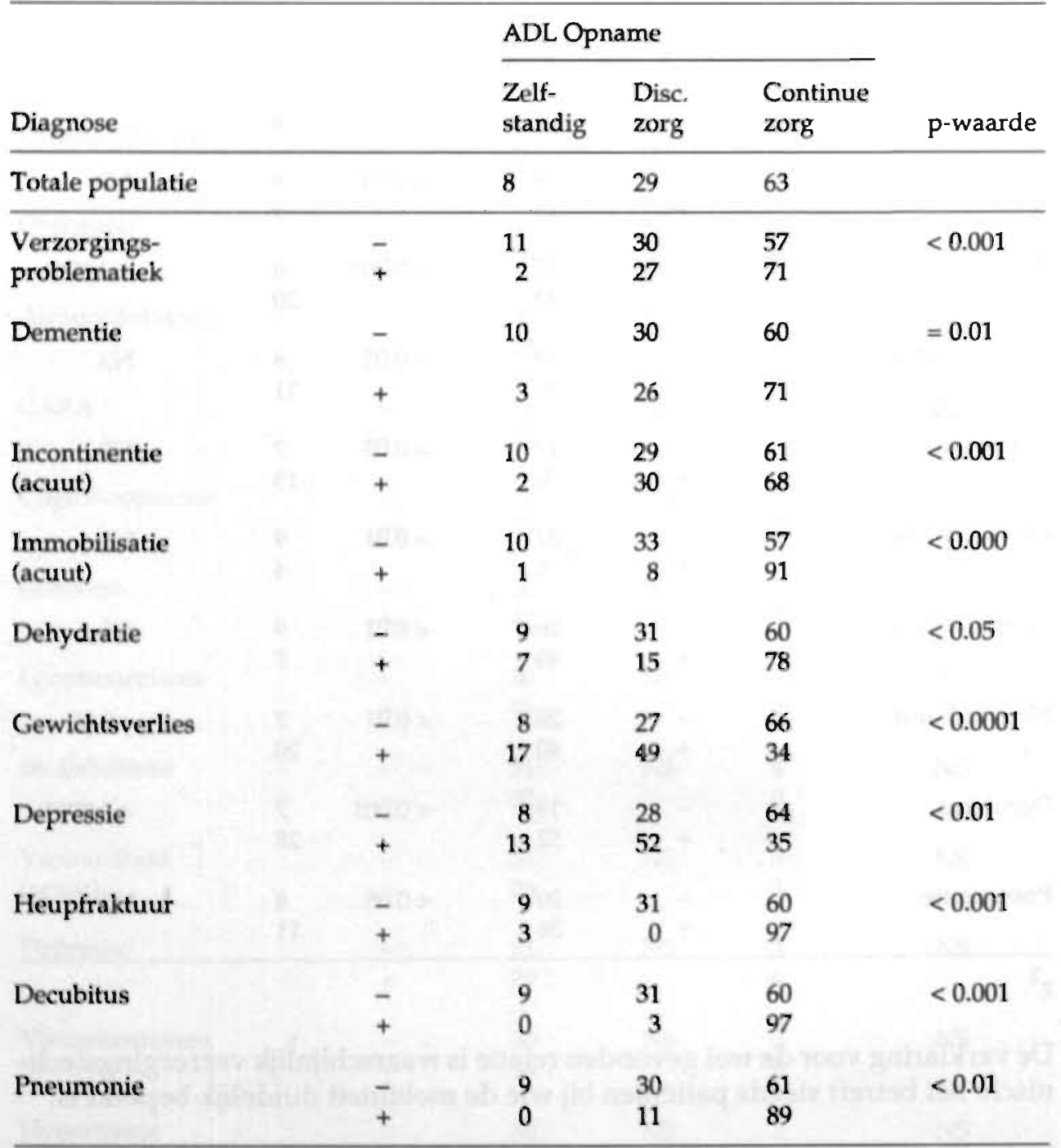

$\chi^{2}$ 


\begin{tabular}{|c|c|c|c|c|c|}
\hline \multirow[b]{2}{*}{ Diagnose } & & \multicolumn{3}{|c|}{ ADL Ontslag. } & \multirow[b]{2}{*}{$\mathrm{p}$-waarde } \\
\hline & & $\begin{array}{l}\text { Zelf- } \\
\text { standig }\end{array}$ & $\begin{array}{l}\text { Disc. } \\
\text { zorg }\end{array}$ & $\begin{array}{l}\text { Continue } \\
\text { zorg }\end{array}$ & \\
\hline Totale populatie & & 20 & 44 & 36 & \\
\hline $\begin{array}{l}\text { Verzorgings- } \\
\text { problematiek }\end{array}$ & + & $\begin{array}{r}26 \\
7\end{array}$ & $\begin{array}{l}43 \\
46\end{array}$ & $\begin{array}{l}31 \\
48\end{array}$ & $<0.000$ \\
\hline Dementie & $\begin{array}{l}- \\
+\end{array}$ & $\begin{array}{r}25 \\
8\end{array}$ & $\begin{array}{l}45 \\
40\end{array}$ & $\begin{array}{l}30 \\
52\end{array}$ & $<0.000$ \\
\hline $\begin{array}{l}\text { Incontinentie } \\
\text { (acuut) }\end{array}$ & $\begin{array}{l}- \\
+\end{array}$ & $\begin{array}{l}22 \\
10\end{array}$ & $\begin{array}{l}44 \\
40\end{array}$ & $\begin{array}{l}67 \\
33\end{array}$ & $<0.01$ \\
\hline $\begin{array}{l}\text { Immobilisatie } \\
\text { (acuut) }\end{array}$ & - & $\begin{array}{r}22 \\
7\end{array}$ & $\begin{array}{l}47 \\
27\end{array}$ & $\begin{array}{r}3 \\
31\end{array}$ & $<0.000$ \\
\hline CARA & - & $\begin{array}{l}19 \\
26\end{array}$ & $\begin{array}{l}42 \\
53\end{array}$ & $\begin{array}{l}39 \\
21\end{array}$ & $<0.05$ \\
\hline Cogn.stoornis & + & $\begin{array}{r}21 \\
6\end{array}$ & $\begin{array}{l}43 \\
51\end{array}$ & $\begin{array}{l}36 \\
43\end{array}$ & $<0.05$ \\
\hline Loopstoornis & 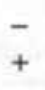 & $\begin{array}{r}21 \\
6\end{array}$ & $\begin{array}{l}43 \\
46\end{array}$ & $\begin{array}{l}35 \\
48\end{array}$ & $<0.05$ \\
\hline Heupfraktuur & - & $\begin{array}{r}21 \\
0\end{array}$ & $\begin{array}{l}44 \\
45\end{array}$ & $\begin{array}{l}35 \\
55\end{array}$ & $=0.01$ \\
\hline Decubitus & $\overline{-}$ & $\begin{array}{r}21 \\
7\end{array}$ & $\begin{array}{l}45 \\
21\end{array}$ & $\begin{array}{l}34 \\
73\end{array}$ & $<0.001$ \\
\hline
\end{tabular}

$x^{2}$

Bij de 8 ziektebeelden die een negatieve invloed hebben op het ADL-funktioneren betreft het éénmaal een specifiek orgaandiagnose: heupfrakturen $(p=0.01)$. De somatische georienteerde problematiek: acute immobilisatie $(p<0.000)$, acute incontinentie, loopstoornissen $(p<0.05)$ en decubitus heeft een duidelijke relatie met stoornissen in de mobiliteit. De overige diagnoses/problemen: dementie, verzorgingsproblematiek en cognitieve stoornissen behoren alle tot het zogenaamd geriatrisch cluster. Het ontbreken van een relatie met de andere, veelal meer orgaangerichte, diagnoses bevestigt het idee dat niet zozeer het orgaanfalen, maar veeleer de funktionele beperkingen het zelfzorgvermogen van patiënten bepaalt. 
Tabel 6.3.4 Diagnoses en Mobiliteit bij opname en bij ontslag van de bij opname niet bedlegerige patiënten. Alleen significante diagnoses in volgorde van frequentie van aantallen patiënten per diagnose. $\mathrm{n}=337$. Alle getallen: percentages.

\begin{tabular}{|c|c|c|c|c|}
\hline \multirow[b]{2}{*}{ Diagnose } & & \multicolumn{2}{|c|}{ Mobiliteit opnanne } & \multirow[b]{2}{*}{ p-waarde } \\
\hline & & $\begin{array}{l}\text { Zelf- } \\
\text { standig }\end{array}$ & $\begin{array}{l}\text { Personele } \\
\text { hulp }\end{array}$ & \\
\hline Totale populatie & & 52 & 48 & \\
\hline $\begin{array}{l}\text { Verzorgings- } \\
\text { problematiek }\end{array}$ & $\overline{+}$ & $\begin{array}{l}57 \\
42\end{array}$ & $\begin{array}{l}43 \\
58\end{array}$ & $<0.05$ \\
\hline $\begin{array}{l}\text { Incontinentie } \\
\text { (aculut) }\end{array}$ & + & $\begin{array}{l}57 \\
32\end{array}$ & $\begin{array}{l}43 \\
68\end{array}$ & $<0.001$ \\
\hline $\begin{array}{l}\text { Immobilisatie } \\
\text { (acuut) }\end{array}$ & + & $\begin{array}{l}57 \\
16\end{array}$ & $\begin{array}{l}43 \\
84\end{array}$ & $<0.000$ \\
\hline Dehydratie & + & $\begin{array}{l}54 \\
32\end{array}$ & $\begin{array}{l}46 \\
68\end{array}$ & $<0.05$ \\
\hline Loopstoornissen & $\begin{array}{l}- \\
+\end{array}$ & $\begin{array}{l}54 \\
31\end{array}$ & $\begin{array}{l}46 \\
69\end{array}$ & $<0.05$ \\
\hline Heupfraktuur & $\begin{array}{l}- \\
+\end{array}$ & $\begin{array}{l}53 \\
14\end{array}$ & $\begin{array}{l}47 \\
86\end{array}$ & $=0.01$ \\
\hline
\end{tabular}

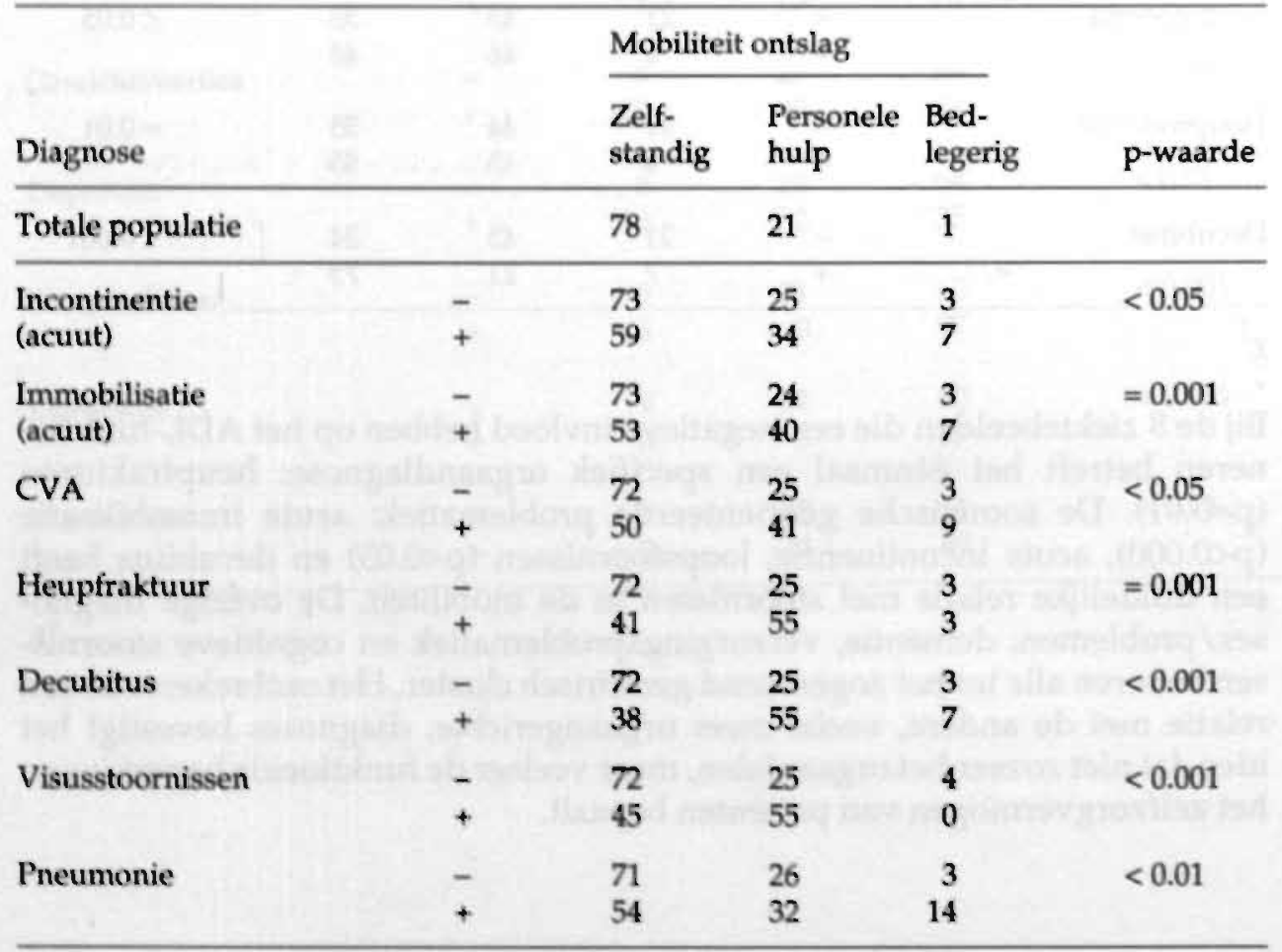




\section{Mobiliteit}

De diagnoses die een significante relatie hebben met de mobiliteit bij ontslag (tabel 6.3.4) zijn voor een deel dezelfde als bij het ADL-funktioneren: acute immobilisatie, incontinentie, decubitus en heupfrakturen. Daarnaast zijn van invloed: visusstoornissen, CVA en pneumonie. Duidelijk blijkt dat de funktionele beperkingen meer samenhangend met het psychisch funktioneren hier geen rol van betekenis spelen. Op een enkele uitzondering na zijn het specifiek de aandoeningen die het bewegingsapparaat direkt (bijv. heupfrakturen) of indirekt (bijv. visusstoornissen) betreffen die hier de overhand hebben. De relatie met pneumonie moet waarschijnlijk net als in een eerder stadium verklaard worden op basis van comorbiditeit met een aantal andere mobiliteitsbeperkende aandoeningen.

\section{Incontinentie}

De relatie tussen de diagnoses en urine-incontinentie is vergelijkbaar met het ADL-funktioneren (tabel 6.3.5). Deels betreft het weer de somatische problemen, nl. heupfrakturen, decubitus, acute(!) incontinentie en immobilisatie. Daarnaast zijn dementie, verzorgingsproblematiek en cognitieve stoornissen in verband te brengen met incontinentie. Ook bestaat een relatie met depressieve klachten, maar dan in omgekeerde zin. Waarschijnlijk is dat depressieve klachten frequenter dan andere problematiek relatief geisoleerd voorkomen. Volgens de Jaccard analyse is alleen een relatie met gewichtsverlies - niet onverwacht - evident. Het begrip 'acute incontinentie' heeft meer betekenis voor het ontstaan van incontinentieklachten (bijvoorbeeld in het kader van een CVA of diabetische problematiek) dan voor het passagère karakter, gelet op de significante relatie met incontinentie bij ontslag. 
Tabel 6.3.5 Diagnoses en Incontinentie bij opname en bij ontslag van de patiënten die bij opname geen catheter hebben. Alleen significante diagnoses in volgorde van frequentie van aantallen patiënten per diagnose. $n=384$. Alle getallen: percentages.

\begin{tabular}{|c|c|c|c|c|c|}
\hline \multirow[b]{2}{*}{ Diagnose } & & \multicolumn{3}{|c|}{ Incontinentie opname } & \multirow[b]{2}{*}{ p-waarde } \\
\hline & & niet & zelden & frequent & \\
\hline Totale populatie & & 49 & 26 & 25 & \\
\hline $\begin{array}{l}\text { Verzorgings- } \\
\text { problematiek }\end{array}$ & + & $\begin{array}{l}53 \\
35\end{array}$ & $\begin{array}{l}23 \\
33\end{array}$ & $\begin{array}{l}24 \\
32\end{array}$ & $<0.01$ \\
\hline Dementie & $\begin{array}{l}- \\
+\end{array}$ & $\begin{array}{l}54 \\
33\end{array}$ & $\begin{array}{l}24 \\
31\end{array}$ & $\begin{array}{l}23 \\
36\end{array}$ & $=0.001$ \\
\hline $\begin{array}{l}\text { Incontinentie } \\
\text { (acuut) }\end{array}$ & $\overline{+}$ & $\begin{array}{l}55 \\
12\end{array}$ & $\begin{array}{l}25 \\
29\end{array}$ & $\begin{array}{l}20 \\
59\end{array}$ & $<0.0000$ \\
\hline $\begin{array}{l}\text { Immobilisatie } \\
\text { (acuut) }\end{array}$ & $\begin{array}{l}- \\
+\end{array}$ & $\begin{array}{l}51 \\
23\end{array}$ & $\begin{array}{l}27 \\
34\end{array}$ & $\begin{array}{l}24 \\
43\end{array}$ & $=0.001$ \\
\hline $\begin{array}{l}\text { Urineweg- } \\
\text { infektie }\end{array}$ & $\overline{+}$ & $\begin{array}{l}50 \\
35\end{array}$ & $\begin{array}{l}27 \\
17\end{array}$ & $\begin{array}{l}23 \\
48\end{array}$ & $<0.01$ \\
\hline Dehydratie & + & $\begin{array}{l}49 \\
39\end{array}$ & $\begin{array}{l}27 \\
17\end{array}$ & $\begin{array}{l}24 \\
44\end{array}$ & $<0.05$ \\
\hline CARA & + & $\begin{array}{l}46 \\
66\end{array}$ & $\begin{array}{l}27 \\
20\end{array}$ & $\begin{array}{l}28 \\
15\end{array}$ & $<0.05$ \\
\hline Loopstoornis & $\begin{array}{l}- \\
+\end{array}$ & $\begin{array}{l}50 \\
28\end{array}$ & $\begin{array}{l}26 \\
26\end{array}$ & $\begin{array}{l}24 \\
46\end{array}$ & $<0.01$ \\
\hline
\end{tabular}

$x^{2}$ 


\begin{tabular}{|c|c|c|c|c|c|c|}
\hline \multicolumn{2}{|l|}{ Diagnose } & \multirow{2}{*}{$\begin{array}{l}\text { niet } \\
55\end{array}$} & \multirow{2}{*}{$\begin{array}{l}\text { zelden } \\
25\end{array}$} & frequent & catheter & \multirow[t]{2}{*}{ p-waarde } \\
\hline Totale populatie & & & & 16 & 4 & \\
\hline Verzorgings- & - & 56 & 25 & 11 & 8 & $<0.000$ \\
\hline problematiek & + & 36 & 25 & 29 & 10 & \\
\hline \multirow[t]{2}{*}{ Dementie } & - & 58 & 22 & 11 & 8 & $<0.000$ \\
\hline & + & 29 & 31 & 30 & 9 & \\
\hline \multirow{2}{*}{$\begin{array}{l}\text { Incontinentie } \\
\text { (acuut) }\end{array}$} & - & 58 & 24 & 10 & 8 & $<0.000$ \\
\hline & + & 14 & 32 & 45 & 10 & \\
\hline \multirow{2}{*}{$\begin{array}{l}\text { Immobilisatie } \\
\text { (acuut) }\end{array}$} & - & 54 & 24 & 16 & 7 & $<0.00001$ \\
\hline & + & 27 & 31 & 23 & 20 & \\
\hline \multirow[t]{2}{*}{ Cogni-stoornis } & - & 51 & 24 & 16 & 9 & $<0.05$ \\
\hline & + & 31 & 33 & 28 & 8 & \\
\hline \multirow[t]{2}{*}{ Heupfraktuur } & - & 51 & 24 & 17 & 8 & $<0.05$ \\
\hline & + & 31 & 34 & 14 & 21 & \\
\hline \multirow[t]{2}{*}{ Depressie } & - & 48 & 25 & 18 & 9 & $<0.01$ \\
\hline & + & 74 & 26 & 0 & 0 & \\
\hline \multirow[t]{2}{*}{ Decubitus } & - & 51 & 25 & 17 & 7 & \\
\hline & + & 31 & 31 & 10 & 28 & $<0.0001$ \\
\hline
\end{tabular}

$\chi^{2}$

Uit bovenstaande analyse van het verband tussen specifieke diagnoses/problemen en het funktioneren bij ontslag blijkt, dat er een beperkt aantal diagnoses - deels somatisch, deels psychisch/cognitief, een merendeels negatieve invloed heeft op het funktioneren.

Van de 28 onderzochte diagnoses zijn er daarnaast 12 waarbij in het geheel geen significante relatie met het funktioneren is aangetoond. In het algemeen betreft dit diagnoses die een meer orgaanbepaald karakter hebben en minder specifiek geriatrisch van aard (b)lijken. Geriatric Giants zoals incontinentie, immobilisatie, cognitieve stoornissen, dementie, verzorgingsproblematiek, dehydratie keren steeds weer terug als prognostisch ongunstige faktoren. Het zijn met name de meer complexe funkties die hierdoor worden getroffen, in het bijzonder ADL-funktioneren en incontinentie. Mobiliteit wordt meer in het bijzonder beperkt door zuiver lichamelijke faktoren. Bedlegerigheid als ultieme uitkomst van mobiliteitsstoornissen is zeldzaam, ongeacht de voorliggende somatische en/of psychisch/cognitieve problematiek. 
Het is niet onbelangrijk hierbij te vermelden dat de onderzochte patiëntengroep in het kader van het Flankerend Geriatrisch Beleid systematisch en intensief is begeleid op het gebied van zelfzorgvermogen, mobiliteit en incontinentieproblematiek. De gevonden uitkomsten moeten dan ook in dit kader worden geïnterpreteerd.

Enerzijds betekent dit dat de resultaten wellicht gunstiger zijn dan in een willekeurige groep geriatrische patiënten, anderzijds kan het zijn dat door meer specifiek aandacht voor (para-)medische aktiviteit gericht op funktieverbetering bij de gevonden risikodiagnoses een gunstiger situatie verkregen kan worden. Dit is met name denkbaar voor die diagnoses/problemen die qua handicapvorming en beperkingen niet onvermijdelijk een verminderd funktioneren tot gevolg hoeven te hebben. Bij opname en behandeling van geriatrische patiënten in het ziekenhuis zal dergelijke aktie vroegtijdig moeten plaatsvinden. De negatieve uitkomsten van bijvoorbeeld heupfrakturen en decubitus zijn in het licht van de bestaande onderlinge korrelatie (zie ook de clusteranalyse met de associatiemaat van Jaccard) hiervan mede het bewijs.

De onderlinge verwevenheid van bepaalde afzonderlijke diagnoses die in het vorige hoofdstuk tot uiting komen in de clusteranalyse met de associatiemaat van Jaccard blijkt ook in funktioneel opzicht relevant. Het zijn met name de clusters V (heupfrakturen en decubitus) en IV (diabetes, acute incontinentie en dehydratie) en I (dementie, cognitieve stoornissen, acute immobilisatie, verzorgingsproblematiek en acute incontinentie) die een voorname, zij het negatieve invloed uitoefenen op het funktioneren op het moment van ontslag. Daarnaast zijn afzonderlijke entiteiten als CVA en pneumonie faktoren met een negatief gevolg voor het funktioneren bij ontslag.

\subsection{De invloed van het Geriatrisch Complex op het funktioneren bij ontslag}

Uit de analyse van de afzonderlijke diagnoses is reeds naar voren gekomen dat de bestanddelen van het Geriatrisch Complex een evidente rol spelen. De invloed van het al dan niet aanwezig zijn van het Geriatrisch Complex blijkt uit tabel 6.4.1.

Geen significante relatie bestaat tussen het complex en bedlegerigheid of cathetergebruik bij ontslag. Daarentegen is de relatie met ADL-funktioneren, mobiliteit en urine-incontinentie bij ontslag overduidelijk.

Van alle volledig ADL-afhankelijke patiënten heeft meer dan $80 \%$ kenmerken van het Geriatrisch Complex. Van ernstige mobiliteitsstoornissen bedraagt dit percentage $62 \%$ en voor ernstige incontinentie zelfs $94 \%$.

Hierbij komt de vraag naar voren in hoeverre het gewicht van het Geriatrisch Complex, d.w.z. het aantal afzonderlijke kenmerken dat bij de individuele patiënt wordt aangetroffen, een rol speelt.

In tabel 6.4.2 is de patiëntengroep uitgesplitst naar nul, één of tenminste twee elementen uit het Geriatrisch Complex. Hieruit blijkt dat er sprake is van een 
Tabel 6.4.1 Funktioneren van patiënten bij opname en ontslag en de aanwezigheid van het Geriatrisch Complex. Alle getallen: percentages. $N=489$.

Opname

\begin{tabular}{|c|c|c|c|}
\hline $\begin{array}{l}\text { Funktionerings- } \\
\text { element }\end{array}$ & $\begin{array}{l}\text { Geriatris } \\
\text { afwezig }\end{array}$ & $\begin{array}{l}\text { omplex } \\
\text { aanwezig }\end{array}$ & p-waarde \\
\hline \multicolumn{4}{|l|}{ Bedlegerig } \\
\hline nee & 36 & 64 & \multirow[t]{2}{*}{ NS } \\
\hline ja & 31 & 69 & \\
\hline \multicolumn{4}{|l|}{ Catheter } \\
\hline nee & 37 & 63 & \multirow[t]{2}{*}{$=0.01$} \\
\hline ja & 24 & 76 & \\
\hline \multicolumn{4}{|l|}{ ADL } \\
\hline zelfstandig & 80 & 20 & \multirow{3}{*}{$<0.000$} \\
\hline discontinue zorg & 36 & 64 & \\
\hline continue zorg & 28 & 72 & \\
\hline \multicolumn{4}{|l|}{ Mobiliteit } \\
\hline zelfstandig & 47 & 53 & \multirow[t]{2}{*}{$<0.001$} \\
\hline personele hulp & 24 & 76 & \\
\hline \multicolumn{4}{|l|}{ Incontinentie } \\
\hline niet & 58 & 42 & \multirow{3}{*}{$<0.000$} \\
\hline zelden & 21 & 79 & \\
\hline frequent & 15 & 80 & \\
\hline
\end{tabular}

Ontslag

Funktionerings-

element

Bedlegerig

nee

ja

Catheter

nee

ja

ADL

zelfstandig

discontinue zorg

continue zorg

Mobiliteit

zelfstandig

personele hulp

bedlegerig

Incontinentie

niet

zelden

frequent

catheter
Geriatrisch Complex

afwezig aanwezig p-waarde

65

NS

38

62

$35 \quad 65$

$27 \quad 73$

$67 \quad 33$

$34 \quad 66$

$18 \quad 82$

$39 \quad 61$

2476

$38 \quad 62$

$54 \quad 46$

$19 \quad 81$

$6 \quad 94$

$27 \quad 73$

$x^{2}$ 
cumulerend effekt, in die zin dat het verschil tussen geen of één kenmerk globaal hetzelfde gewicht in de schalal legt als het verschil tussen één en twee kenmerken. Belangrijk is te konstateren dat hierbij dezelfde waarneming kan worden gedaan als in eerdere analyses, nl.: de invloed op ADL-funktioneren en incontinentie gaat verder dan op de mobiliteit. Patiënten met twee of meer kenmerken van het Geriatrisch Complex zijn wat mobiliteit betreft weliswaar slechter af op het moment van ontslag, maar het verschil t.o.v. de overige patiënten is aanzienlijk geringer dan voor ADL-funktioneren of incontinentie waar betreffende patiënten gemiddeld 0.74 respektievelijk 1.03 verschillen van degenen die geen kenmerken van het Geriatrisch Complex hebben.

Naast het zuiver kwantitatieve cumulerende effekt van het Geriatrisch Complex op het ADL-funktioneren is vervolgens nagegaan hoe afzonderlijke bestanddelen zich onderling verhouden, los van het feit of ze alleen of in kombinatie voorkomen (tabel 6.4.3).

Tabel 6.4.2 Funktioneren in relatie tot het aantal diagnoses binnen het Geriatrisch Complex, namelijk 0,1 of $\geq 2$. Alle getallen: gemiddelden volgens ANOVA.

\section{Aantal diagnoses Geriatrisch Complex}

\begin{tabular}{|c|c|c|c|c|}
\hline Funktioneringselement & 0 & 1 & $\geq 2$ & p-waarde \\
\hline $\mathbf{N}$ & 166 & 170 & 146 & \\
\hline \multicolumn{5}{|l|}{ Bedlegerig $^{1}$} \\
\hline opname & 0.27 & 0.34 & 0.31 & NS \\
\hline ontslag, & 0.04 & 0.02 & 0.04 & NS \\
\hline \multicolumn{5}{|l|}{ Catheter 1} \\
\hline opname & 0.14 & 0.21 & 0.29 & $<0.01$ \\
\hline ontslag & 0.07 & 0.07 & 0.12 & NS \\
\hline \multicolumn{5}{|l|}{$\mathrm{ADL}^{2}$} \\
\hline opname & 2.01 & 2.40 & 2.59 & $<0.000$ \\
\hline ontslag & 1.81 & 2.19 & 2.55 & $<0.000$ \\
\hline \multicolumn{5}{|l|}{ Mobiliteit } \\
\hline opname ${ }^{3}$ & 1.29 & 1.47 & 1.60 & $<0.000$ \\
\hline ontslag ${ }^{4}$ & 1.25 & 1.34 & 1.42 & $<0.05$ \\
\hline \multicolumn{5}{|l|}{ Urine 5} \\
\hline opname 5 & 1.22 & $\begin{array}{l}1.82 \\
1.79\end{array}$ & $\begin{array}{l}2.11 \\
2.43\end{array}$ & $<0.000$ \\
\hline ontslag ${ }^{\circ}$ & 1.40 & 1.79 & 2.43 & $<0.000$ \\
\hline
\end{tabular}

${ }_{2}^{1}$ twee schaalwaarden, 0 en 1 . Na vermenigouldiging met 100 ontstaan percentages

2 drie schaalwaarden, 1 (zelfstandig), 2 (discontinue zorg) en 3 (continue zorg)

3 twee schaalwaarden, 1 (zelfstandig), 2 (personele hulp)

4 drie schaalwaarden, 1 (zelfstandig), 2 (personele hulp) en 3 (bedlegerig)

5 drie schaalwaarden, 1 (nee), 2 (zelden) en 3 (frequent)

${ }^{6}$ vier schaalwaarden, 1 (nee), 2 (zelden), 3 (frequent) en 4 (catheter) 
Tabel 6.4.3 Het gemiddelde van ADL-funktioneren bij ontslag bij aanwezigheid dan wel afwezigheid van afzonderlijke bestanddelen van het Geriatrisch Complex. Bestanddelen in rangorde van voorkomen bij patiënten. $\mathrm{N}$ per categorie met $\mathrm{N}$-totaal $=479$. Toetsing middels ANOVA. $\mathrm{R}^{2}$ : verklaarde variantie (\%).

\begin{tabular}{|c|c|c|c|c|c|}
\hline Bestanddeel & & $\mathrm{N}$ & $\begin{array}{l}\text { ADL- } \\
\text { Ontslag }{ }^{1}\end{array}$ & p-waarde & $\mathrm{R}^{2}$ \\
\hline \multirow[t]{2}{*}{ Verzorgingsproblematiek } & - & 328 & 2.1 & & \\
\hline & + & 151 & 2.4 & $<0.0000$ & 5,1 \\
\hline \multirow[t]{2}{*}{ Dementie } & - & 339 & 2.2. & & \\
\hline & + & 140 & 2.4 & $<0.0000$ & 6,9 \\
\hline \multirow[t]{2}{*}{ Acute incontinentie } & - & 385 & 2.2 & & \\
\hline & + & 94 & 2.4 & $<0.001$ & 2,6 \\
\hline \multirow[t]{2}{*}{ Acute immobilisatie } & - & 404 & 2.1 & & \\
\hline & + & 75 & 2.6 & $<0.0000$ & 6,5 \\
\hline \multirow[t]{2}{*}{ Cogn.stoornissen } & - & 428 & 2.1 & & \\
\hline & + & 51 & 2.4 & $<0.05$ & 0,9 \\
\hline
\end{tabular}

${ }^{1}$ drie schaalwaarden: 1 (zelfstandig), 2 (discontinue zorg) en 3 (continue zorg)

De invloed op het ADL-funktioneren is voor alle bestanddelen significant. In absolute zin varieert de invloed van 0.2 tot 0.5 gemiddeld, bij een bandbreedte van 2.0 ofwel van $10 \%$ tot $25 \%$. De hieruit berekende verklaarde variantie geeft vervolgens een enigszins hiërarchische rangorde waarbij acute immobilisatie, dementie en verzorgingsproblematiek zwaarder wegen dan acute incontinentie en cognitieve stoornissen.

\subsection{Samengestelde analyses van het funktioneren bij ontslag}

In het voorafgaande is uitgaande van bepaalde enkelvoudige gegevens nagegaan welke relatie er bestaat met het funktioneren bij ontslag. Duidelijk is geworden dat er een zekere samenhang bestaat tussen afzonderlijke gegevens en dat bijvoorbeeld het zogenaamde Geriatrisch Complex een samenhang van bepaalde problematiek vertegenwoordigt die van invloed is op het funktioneren van de onderzochte patiëntengroep bij ontslag uit het ziekenhuis. Een probleem dat zich bij deze analysetechniek voordoet is dat, alhoewel afzonderlijke variabelen worden gehanteerd, de uitkomst toch een samengesteld effekt behelst, $\mathrm{nl}$. het effekt van de onderzochte variabelen, in kombinatie met niet nader benoemde hiermee samenhangende faktoren.

Om de invloed van afzonderlijke faktoren op zich nader te onderzoeken is gebruik gemaakt van regressie-analyse met als afhankelijke variabelen het ADL-funktioneren bij ontslag en incontinentie bij ontslag. 
Regressie-analyse ADL-funktioneren bij ontslag

Als onafhankelijke variabelen zijn ingevoerd het ADL-funktioneren bij opname, de woonsituatie voor opname, leeftijd, geslacht, de 28 afzonderlijke diagnoses minus de diagnoses van het Geriatrisch Complex en het Geriatrisch Complex (cluster I).

De uitkomst van deze analyse staat in tabel 6.5.1.

Tabel 6.5.1 Regressie-analyse met als afhankelijke variabele het ADL-funktioneren bij ontslag: onafhankelijke variabelen met een significant $\beta$-gewicht, met $T$ de toets voor die significantie. Variabelen in rangorde van hun $\beta^{\prime}$ s. Multiple $R, R^{2}$, en de significantie van $R$. $(n=489)$

\begin{tabular}{lcrl}
\hline Onafhankelijke variabelen & B-gewicht & \multicolumn{1}{l}{$T$} & Sign T \\
\hline ADL-opname & 0.43 & 11.5 & 0.0000 \\
Geriatrisch Complex & 0.28 & 7.7 & 0.0000 \\
Woonsituatie voor opname & 0.18 & 5.0 & 0.0000 \\
Decubitus & 0.10 & 2.7 & 0.0077 \\
Geslacht & 0.08 & 2.3 & 0.02 \\
CVA & 0.07 & 2.1 & 0.04 \\
Leeftijd & 0.06 & 1.8 & 0.08 \\
Atriumfibrilleren & -0.09 & 2.1 & 0.03 \\
\hline
\end{tabular}

Multiple $R=0.66 ; R^{2}=0.43 ; F=39.426 ; p=0.000$

De verklaarde variantie op basis van de variabelen woonsituatie, Geriatrisch Complex, ADL-funktioneren bij opname, geslacht, leeftijd, decubitus, verwardheid, atriumfibrilleren en CVA bedraagt $65.7 \%$. Veruit de belangrijkste onafhankelijke variabele is het $\mathrm{ADL}$-funktioneren bij opname. Van overwegend belang zijn voorts de woonsituatie voor opname en het Geriatrisch Complex. Deze drie variabelen tesamen verklaren $62.7 \%$. Van belang is daarbij de konstatering dat uitsluitend (elementen van) het Geriatrisch Complex gedurende opname therapeutisch beïnvloedbaar zijn. Leeftijd en geslacht - in eerdere analyse niet in significante relatie te brengen met het funktioneren bij ontslag - hebben een geringe doch significante bijdrage in de verklaarde variantie, evenals de diagnoses decubitus, acute verwardheid, atriumfibrilleren en CVA. De bijdrage van laatstgenoemde is gering.

Conform de verwachting gebaseerd op voorgaande analyse zijn de overige diagnoses niet van significante betekenis.

\section{Regressie-analyse urine-incontinentie bij ontslag}

Als onafhankelijke variabelen zijn ingevoerd incontinentie bij opname, CVA, mediane opnameduur, geslacht, woonsituatie, leeftijd, de clusters I (Geriatrisch Complex), II, IV, V en de diagnoses pneumonie en CVA. De uitkomst van de analyse staat in tabel 6.5.2. 
Tabel 6.5.2 Regressie-analyse met als afhankelijke variabele incontinentie bij ontslag: onafhankelijke variabelen met een significant $\beta$-gewicht, met $\mathrm{T}$ de toets voor die significantie. Variabelen in rangorde van hun $\beta$ 's. Multiple $R, R^{2}$, en de significantie van $R$.

\begin{tabular}{llrl}
\hline Onafhankelijke variabelen. & $\beta$-gewicht & \multicolumn{1}{l}{$\mathrm{T}$} & Sign T \\
\hline Incontinentie opname & 0.52 & 12.5 & 0.0000 \\
Geriatrisch Complex & 0.21 & 5.1 & 0.0000 \\
Geslacht & 0.11 & 3.0 & 0.0026 \\
Mediane opnameduur & 0.10 & 2.7 & 0.0076 \\
Pneumonie & 0.09 & 2.3 & 0.0247 \\
\hline
\end{tabular}

Multiple $R=0.69 ; R^{2}=0.47 ; F=67.226 ; p=0.000$

De verklaarde variantie op basis van de variabelen incontinentie bij opname, mediane opnameduur, geslacht, pneumonie en Geriatrisch Complex bedraagt $68.8 \%$ Ook hier blijkt de situatie bij opname de belangrijkste variabele. Van de overige verklaarde variabelen is de zwaarst wegende het Geriatrisch Complex. De bijdrage van mediane duur, pneumonie en geslacht is ongeveer gelijkwaardig, maar verklaart slechts een gering percentage.

Op basis van deze regressie analyses mag gekonkludeerd worden dat voor het funktioneren bij ontslag de belangrijkste verklarende, maar niet beinvloedbare, variabele is het funktioneren bij opname. Van de wel (?) beinvloedbare variabelen is het Geriatrisch Complex veruit het belangrijkst. Gelet op het eerder gekonstateerde negatieve en cumulerend effekt dat de bestanddelen van dit complex hebben is identifikatie van de bestanddelen van dit complex en zo mogelijk eliminatie een mogelijk handvat voor verbetering van de prognose in funktioneel opzicht. Toch moet deze konstatering tegelijkertijd met enige scepsis worden bekeken omdat in de onderhavige studie niet gemeten is wat de invloed is van mutaties gedurende opname in het Geriatrisch Complex, maar uitsluitend het belang van het op enigerlei moment aanwezig zijn van genoemde elementen.

\section{Discriminant analyse ADL-funktioneren}

Een ten behoeve van verder verklarende analyse bijzondere plaats worden ingenomen door de patiënten die bij opname qua ADL-funktioneren vallen in de zogenaamde tussencategorie (d.w.z. ADL-opname=2), omdat dergelijke patiënten gedurende het verblijf in het ziekenhuis zowel vooruit als achteruit kunnen gaan.

Deze situatie doet zich voor bij 139 patiënten en hiervoor is een dicriminantanalyse uitgevoerd met als doel na te gaan welke unieke variabelen vooruitgang danwel achteruitgang veroorzaken. ADL-opname is hierbij dus gehanteerd als een konstant gegeven. Als onafhankelijke variabelen zijn dezelfde variabelen ingevoerd die gebruikt zijn in de regressie analyse, met 
uitzondering van de diagnoses pneumonie, decubitus, heupfraktuur en CVA omdat deze variabelen in de onderzochte groep te weinig frequent voorkomen. De uitkomst van deze analyse is weergegeven in tabel 6.5.3.

Tabel 6.5.3 Discriminantanalyse: ADL-funktioneren bij ontslag van patiènten met lichte ADL-stoornissen bij opname, $\mathbf{n}=139$.

\begin{tabular}{lll}
\hline Onafhankelijke variabelen & Gewicht $^{1}$ & Correlatie $^{2}$ \\
\hline Geslacht & 0.34 & 0.31 \\
Woonsituatie & 0.45 & 0.39 \\
Mediane opnameduur & 0.48 & 0.58 \\
Geriatrisch Complex & 0.67 & 0.65 \\
\hline
\end{tabular}

Wilks' lambda: $0.80 ; p=0.0003$; Correct voorspeld: $64.5 \% ;{ }^{1}$ Gestandaardiseerde gewichten; ${ }^{2}$ namelijk met de canonische funktie

Uit deze analyse komt het Geriatrisch Complex als belangrijkste variabele naar voren. De overige voorspellende variabelen zijn geslacht, woonsituatie voor opname en mediane opnameduur.

Met behulp van deze vier variabelen kan de uitkomst wat het ADL-funktioneren betreft korrekt voorspeld worden in $2 / 3$ van de gevallen $(64,5 \%)$.

De beperkingen ten aanzien van de therapeutische implikaties van deze gegevens, zoals vermeld bij de regressie analyse, gelden vanzelfsprekend ook voor deze analyse.

Desalniettemin is van belang dat slechts een zeer beperkt aantal variabelen beschikbaar hoeft te zijn om een uitspraak te kunnen doen over de uitkomst wat betreft het funktioneren bij ontslag. Gelet op de aanwezigheid van de variabele mediane duur zal eerst nadat de patiënt de mediane opnameduur gepasseerd is de voorspelling bruikbaar zijn, tenzij tevoren een voorspelling gedaan kan worden of betreffende patiënt korter danwel langer dan de mediane duur in het ziekenhuis zal verblijven. 


\subsection{De ontslagrichting in relatie tot het funktioneren en de onderzochte clusters}

Bij ontslag keert $63 \%$ van de patiënten terug naar een zelfstandige woonsituatie (tabel 6.6.1).

Tabel 6.6.1 De ontslagrichting van de onderzochte geriatrische patiênten in aantallen en percentages $(n=489)$.

\begin{tabular}{lrr}
\hline & n & $\%$ \\
\hline Zelfstandige woonsituatie & 308 & 63 \\
Verzorgingshuis & 59 & 12 \\
Somatisch VPH & 49 & 10 \\
PG VPH & 51 & 10 \\
Overige & 22 & 4 \\
Totaal & 489 & 100 \\
\hline
\end{tabular}

PG = psychogeriatrisch; $V P H=$ verpleeghuis

De overige patiënten gaan in vrijwel gelijke percentages naar een (kleinschalig) verzorgingstehuis, een somatische verpleegafdeling of een psychogeriatrische verpleeghuisafdeling.

Zoals verondersteld mag worden is het funktioneren bij de keuze van de uiteindelijke ontslagrichting van doorslaggevend belang. Opmerkelijk is dat uit de gegevens blijkt dat dit zowel geldt voor het funktioneren bij opname als bij ontslag. Voor elk van de onderzochte parameters geldt dat het al dan niet aanwezig zijn (bedlegerigheid, catheter), respektievelijk de mate waarin beperkingen aanwezig zijn (ADL-funktioneren, mobiliteit, incontinentie problematiek) leidt tot significante verschillen in het percentage patiënten dat naar een zelfstandige woonsituatie kan worden ontslagen (tabel 6.6.2). Ernstige mobiliteitsstoornissen, bedlegerigheid, ernstige urine-incontinentie of het hebben van een catheter zijn ongunstige faktoren zowel voor terugplaatsing naar huis als voor plaatsing in een verzorgingstehuis.

Uit de relatie tussen de clusters en de ontslagrichting blijkt dat de aanwezigheid van cluster V (heupfrakturen, decubitus) en/of cluster I (het Geriatrisch Complex) duidelijk van invloed zijn. Bij aanwezigheid van deze clusters is de kans op opname in een verpleeghuis sterk toegenomen. Voorts blijkt dat zowel voor cluster II (cardiale problematiek) als voor cluster VII (depressie en anorexie) geldt dat juist een verhoogde kans bestaat op terugkeer naar de eigen woonsituatie. De verklaring hiervoor kan zijn dat voor deze clusters geldt dat relatief vaak zodanig herstel gedurende ziekenhuisopname mogelijk is (het gaat om de niet-overleden patiënten) dat toegenomen zorgbehoefte door blijvende beperkingen of handicaps relatief weinig voorkomt (tabel 6.6.3). 
Tabel 6.6.2 De ontslagrichting in relatie tot het funktioneren bij opname en ontslag $(n=489)$, percentages.

\begin{tabular}{|c|c|c|c|c|c|}
\hline & & $Z W$ & $\mathrm{VZH}$ & VPH & p-waarde \\
\hline Totale populatie & & 65 & 12 & 21 & \\
\hline \multirow[t]{2}{*}{ Bedlegerige opname } & - & 78 & 14 & 14 & $<0.000$ \\
\hline & + & 51 & 10 & 38 & \\
\hline \multirow[t]{2}{*}{ Catheter opname } & - & 68 & 14 & 18 & $<0.0001$ \\
\hline & + & 52 & 14 & 38 & \\
\hline \multirow[t]{2}{*}{ Bedlegerig ontslag } & - & 66 & 11 & 20 & $<0.001$ \\
\hline & + & 33 & 13 & 67 & \\
\hline \multirow[t]{2}{*}{ Catheter ontslag } & - & 67 & 0 & 19 & $<0.000$ \\
\hline & + & 37 & 14 & 58 & \\
\hline \multicolumn{6}{|l|}{ ADL-opname } \\
\hline zelfstandig & & 87 & 5 & 0 & \\
\hline discontinue hulp & & 75 & 13 & 11 & $<0.000$ \\
\hline continue hulp & & 59 & 14 & 29 & \\
\hline \multicolumn{6}{|l|}{ Mob-opname } \\
\hline zelfstandig & & 90 & 12 & 6 & $<0.0001$ \\
\hline afh.pers.hulp & & 62 & 14 & 24 & \\
\hline \multicolumn{6}{|l|}{ Inc-opname } \\
\hline niet incontinent & & 78 & 13 & 10 & \\
\hline zelden incontinent & & 65 & 12 & 23 & $<0.000$ \\
\hline frequent incontinent & & 56 & 17 & 28 & \\
\hline \multicolumn{6}{|l|}{ ADL-ontslag } \\
\hline zelfstandig & & 84 & 13 & 3 & \\
\hline discontinue hulp & & 72 & 17 & 11 & $<0.000$ \\
\hline continue & & 48 & 8 & 45 & \\
\hline \multicolumn{6}{|l|}{ Mob-ontslag } \\
\hline zelfstandig & & 72 & 16 & 12 & \\
\hline afh.pers.hulp & & 50 & 7 & 43 & $<0.000$ \\
\hline bedlegerig & & 33 & 0 & 67 & \\
\hline \multicolumn{6}{|l|}{ Inc.-ontslag } \\
\hline niet incontinent & & 79 & 13 & 9 & \\
\hline zelden incontinent & & 63 & 14 & 24 & $<0.000$ \\
\hline frequent incontinent & & 46 & 17 & 38 & \\
\hline catheter & & 38 & 5 & 58 & \\
\hline
\end{tabular}

$\chi^{2} \cdot \mathrm{ZW}=$ zelfstandige woonsituatie $\mathrm{VZH}=$ verzorgingshuis $\mathrm{VPH}=$ perpleeghuis 
Tabel 6.6.3 De relatie tussen de ontslagrichting en het al dan niet aanwezig zijn van kenmerken (behorend tot de clusters, uitgedrukt in percentages $(n=489)$.

\begin{tabular}{lccccc}
\hline Cluster & & ZW & VZH & VPH & p-waarde \\
\hline Geriatrisch Complex & - & 81 & 7 & 12 & $<0.000$ \\
& + & 57 & 16 & 27 & \\
Cardiaal & - & 63 & 13 & 24 & $<0.05$ \\
& + & 83 & 12 & 15 & \\
Visusstoornissen & - & 63 & 13 & 23 & NS \\
& + & 72 & 12 & 16 & \\
Diabetes & - & 66 & 14 & 20 & NS \\
& + & 63 & 12 & 25 & \\
Heupfrakturen & - & 68 & 14 & 18 & $<0.000$ \\
& + & 32 & 6 & 51 & \\
Hypertensie & - & 66 & 13 & 21 & NS \\
& + & 63 & 11 & 26 & \\
Depressie & - & 62 & 14 & 23 & $<0.05$ \\
& + & 79 & 9 & 12 & \\
Anaemie & - & 67 & 13 & 22 & NS \\
& + & 67 & 12 & 21 & \\
\hline
\end{tabular}

$Z W=$ zelfstandige woonsituatie,$V Z H=$ verzorgingshuis; $V P H=$ verpleeghuis

\subsection{Samenvatting}

Het funktioneren bij ontslag vergeleken met de situatie bij opname uitgedrukt in ADL-behoeftigheid, mobiliteit en urine-incontinentie is voor de onderzochte patiëntengroep als geheel significant beter. Dit geldt ook voor de subgroepen van patiënten die op elk van de onderscheiden funkties zodanig funktioneren bij opname dat zowel verbetering als verslechtering mogelijk is. Leeftijd en geslacht zijn niet van invloed op de uitkomsten wat het funktioneren betreft bij ontslag.

De invloed van de 28 meest voorkomende diagnoses op het funktioneren bij ontslag is uitermate beperkt. De diagnoses die frequent geassocieerd zijn met stoornissen in de mobiliteit en in het bijzonder de diagnoses die een onderdeel vormen van het Geriatrisch Complex hebben direkt of indirekt de sterkste invloed op het funktioneren. Naarmate meer kenmerken van het Geriatrisch Complex aanwezig zijn is het funktioneren bij ontslag slechter. Dit komt overeen met de eerder geuite veronderstelling dat typisch geriatrische patiënten zich gedurende opname in het ziekenhuis anders gedragen dan gewone 
ouderen (hoofdstuk 4). De invloed van het Geriatrisch Complex als belangrijkste faktor bij het funktioneren op het moment van ontslag, wordt bevestigd door de uitkomsten van regressie en discriminant-analyse van de faktoren die mogelijk het ADL-funktioneren bij ontslag en urine-incontinentie bij ontslag zouden kunnen beïnvloeden. De klinische betekenis en de invloed op het (geriatrisch) handelen worden eens te meer duidelijk, waar blijkt dat de aanwezigheid van het Geriatrisch Complex ook doorwerkt in de uiteindelijke ontslagrichting. 


\section{Het profiel en de bijzondere kenmerken van de overleden patiënten}

In hoofdstuk 4 is gekonstateerd dat de onderzochte groep van 546 geriatrische patiënten een significant hoger percentage overledenen kent dan een wat leeftijd en geslacht betreft vergelijkbare populatie in het ziekenhuis opgenomen oudere patiënten ( $18 \%$ versus $4 \%$ ). De doelstelling van dit hoofdstuk is na te gaan in hoeverre aan de hand van de beschikbare onderzoeksgegevens verschil kan worden aangetoond tussen de patiënten die wel en niet overleden zijn in de onderzoeksgroep. Hiertoe is allereerst nagegaan wat de invloed is van geslacht, leeftijdskategorie, gemiddelde opnameduur en de kwantitatieve ziektelast (als uiting van multiple pathologie). Vervolgens wordt geanalyseerd in hoeverre specifieke diagnoses of diagnosegroepen van invloed zijn. Als derde faktor van betekenis worden de gegevens omtrent het funktioneren bij opname geanalyseerd in relatie tot overlijden. Tenslotte wordt met behulp van logistische regressie nagegaan wat de betekenis van een aantal relevante parameters met hun onderlinge interaktie is.

\subsection{De invloed van basale variabelen op het overlijden}

De invloed van leeftijd, geslacht, opnameduur, de 28 meest voorkomende ziektebeelden en de totale kwantitatieve diagnoselast (uitgedrukt in aantal aanwezige aktieve problemen/ziektebeelden) is vergeleken voor 83 patiënten die overleden zijn versus 391 patiënten die niet overleden zijn tijdens de eerste opname.

Het blijkt dat geen significante verschillen worden gevonden voor de onderscheiden elementen. Gemiddeld genomen hebben de overleden patiënten iets meer ziektelast en is de opnameduur korter. Dit laatste is niet significant en kan wellicht verklaard worden uit het feit dat voor overleden patiënten de vaak tijdrovende procedure van het realiseren van de ontslagrichting niet van toepassing is: hemel en hel kennen geen wachtlijst. 
$\mathrm{Bij}$ de kwalitatieve analyse van de specifieke diagnoses is uitgegaan van de 28 meest voorkomende diagnoses en de clusters die hieruit gevormd zijn (zie hoofdstuk V). De verschillen tussen de wel en niet overleden patiënten zijn geanalyseerd voor de patiënten die slechts éénmaal opgenomen zijn geweest. Deze beperking is gesteld om het effekt van chronische ziekten (en daarmee weerkerende zelfde diagnoses) te vermijden. Op deze wijze zijn 474 patiënten geselekteerd waarvan er gedurende opname in het ziekenhuis 83 zijn overleden. Gegevens met betrekking tot de 28 meest voorkomende diagnoses zijn weergegeven in tabel 7.2.1. Van de onderzochte diagnoses zijn er vijf waarvoor een significant verschil gevonden wordt. Decompensatio cordis, CVA en pneumonie worden significant vaker aangetroffen bij patiënten die overlijden. Verzorgingsproblematiek en acute verwardheid komen significant minder vaak voor in de groep overledenen.

Tabel 7.2.1 Het percentuele verschil in overlijden op basis van het al dan niet voorkomen van de 28 meest voorkomende diagnoses in de onderzochte populatie $(n=474)$.

\section{$\%$ overleden p-waarde}

\begin{tabular}{lll}
\hline Totale populatie & 17 & nvt \\
\hline Decompensatio cordis $(\mathrm{n}=84)$ & 31 & $<0.01$ \\
Acute verwardheid $(\mathrm{n}=28)$ & 7 & $<0.05$ \\
CVA $(\mathrm{n}=54)$ & 35 & $<0.01$ \\
Pneumonie $(\mathrm{n}=48)$ & 44 & $<0.000$ \\
Verzorgingsproblematiek $(\mathrm{n}=148)$ & 11 & $<0.01$
\end{tabular}

t-Toets; NB: overige diagnoses geen significante verschillen.

Wanneer het relatieve overlijdensrisiko wordt berekend van de 28 meest voorkomende diagnoses blijkt nagenoeg hetzelfde. Decompensatio cordis, CVA en pneumonie zijn de diagnoses met een significant verhoogd overlijdensrisiko. Patiënten met verzorgingsproblematiek hebben een geringer risiko op overlijden (tabel 7.2.2).

Het in verhoogde frequentie voorkomen van de diagnose pneumonie in de groep overleden patiënten moet met enige voorzichtigheid worden geinterpreteerd. Voor de genoemde diagnoses geldt steeds dat ze op enig moment gedurende opname een aktief probleem gevormd moeten hebben. Niet zelden zal bij patiënten in een - om andere redenen terminale fase - pneumonie de komplikatie zijn die kort voor het overlijden optreedt, of juist de komplikatie vormen waardoor de patiënt komt te overlijden. Weliswaar betreft het een aktief probleem - de postmortem diagnose pneumonie, zoals frequent gesteld bij obductie-onderzoek is niet meegeteld als aktieve diagnose - maar de konklusie dat een pneumonie als zodanig een sterk verhoogd overlijdens- 
Tabel 7.2.2 Het relatieve overlijdensrisico (RR) in relatie tot de 28 meest voorkomende diagnoses in de onderzochte patiëntengroep $(n=474)$.

\begin{tabular}{lll}
\hline & RR & $95 \%$ betrouwbaarheidsinterval \\
\hline Obstipatie & 1,36 & $0,69-2,65$ \\
Acute immobilisatie & 0,64 & $0,31-1,36$ \\
Gehoorstoornissen & 0,77 & $0,31-1,89$ \\
Diabetes & 1,20 & $0,65-2,20$ \\
Decompensatio cordis & 2,62 & $1,52-4,50$ \\
Acute incontinentie & 1,0 & $0,56-1,80$ \\
Rec. vallen & 1,25 & $0,49-3,16$ \\
Depressie & 0,63 & $0,18-2,15$ \\
Dehydratie & 1,45 & $0,76-2,77$ \\
Acute verwardheid & 0,35 & $0,08-1,49$ \\
Mob. stoornissen & 0,77 & $0,31-1,89$ \\
CARA & 1,17 & $0,57-2,38$ \\
Decubitus & 2,0 & $0,93-4,35$ \\
Urineweginfektie & 0,70 & $0,33-1,47$ \\
Vit. B6-deficiëntie & 0,47 & $0,14-1,57$ \\
Dementie & 0,76 & $0,45-1,31$ \\
Anemie & 0,79 & $0,41-1,53$ \\
Atriumfibrilleren & 0,95 & $0,48-1,91$ \\
Visusstoornissen & 1,29 & $0,54-3,09$ \\
Heupfraktuur & 1,56 & $0,68-3,60$ \\
Hypertensie & 0,85 & $0,29-2,53$ \\
Myocardinfarct & 1,98 & $0,84-4,66$ \\
Nierfunktiestoornissen & 1,78 & $0,80-3,97$ \\
CVA & $3,0,2$ & $1,63-5,61$ \\
Pneumonie & 4,57 & $2,43-8,58$ \\
Cogn.stoornissen & 0,73 & $0,32-1,67$ \\
Verzorgingsproblematiek & 0,47 & $0,26-0,84$ \\
Gewichtsverlies & 0,72 & $0,30-1,77$ \\
\hline & & \\
\hline
\end{tabular}

risiko met zich meebrengt kan op grond van bovenstaande redenering niet worden hard gemaakt. Uit het geanalyseerde materiaal is in eerder stadium via clusteranalyse (hoofdstuk 5) gebleken dat de diagnose pneumonie geen specifieke relatie heeft c.q. niet clustert met andere diagnoses. Hieruit kan mogelijk gekonkludeerd worden dat pneumonieën bij een veelheid van diagnoses als extra probleem kunnen optreden en dat dergelijke kombinaties wel een verhoogd overlijdensrisiko hebben.

Het feit dat verzorgingsproblematiek een inverse relatie heeft met overlijden is een opmerkelijk fenomeen. In hoofdstuk 6 is duidelijk geworden dat elementen uit het Geriatrisch Complex, waartoe ook verzorgingsproblematiek behoort een negatieve invloed hebben op het funktioneren en de veranderingen daarin gedurende opname. In analogie aan de redenering over de invloed 
van pneumonie op het overlijden geldt hier wellicht iets soortgelijks, maar met een tegengesteld effekt. Het voorkomen van verzorgingsproblematiek als zodanig heeft door het ontbreken van een direkt biomedisch substraat een gunstig effekt op het overlijdensrisiko. Dit wordt mogelijk versterkt door het feit dat deze probleemstelling veelal mede de opname-indicatie vormt en een neerwaarts effekt heeft op de ernst van de totale diagnoselast die opname noodzakelijk maakt. Ter verduidelijking: gegeven 2 patiënten met een totale diagnoselast van 5,waarbij de één wel en de ander geen verzorgingsproblematiek heeft, zal laatstgenoemde een andere diagnose hebben, die zwaarder drukt op de overlevingskansen.

Onverlet de redenen waarom bovengenoemde diagnoses van invloed zijn op het risiko te overlijden is het van belang te konstateren dat 23 van de 28 onderzochte diagnoses/problemen geen significante relatie hebben met overlijden. Dat de diagnose er derhalve doorgaans niet toe doet is te eenvoudig gekoncludeerd. Meer aannemelijk is dat de funktionele en biomedische betekenis van elke onderzochte diagnose op zich sterk uiteenlopend is: er is niet gebruik gemaakt van een ernst-classificatie. Positieve en negatieve effekten van respektievelijk gunstige en ongunstige stadia/verschijningsvormen kunnen elkaar op deze wijze opheffen. Konkluderend: de gehanteerde diagnoseclassificatie biedt onvoldoende differentiatie om een significante relatie met overlijden aan te tonen.

Nagegaan is vervolgens in hoeverre de zogenaamde clusters een relatie hebben met het overlijden (tabel 7.2.3.).

Tabel 7.2.3 Het verschil in overlijden op basis van het al dan niet aanwezig zijn van één of meerdere elementen uit een cluster in de populatie $(n=474)$.

\begin{tabular}{llll}
\hline & & $\begin{array}{l}\text { Overlijdens- } \\
\text { percentage }\end{array}$ & p-waarde \\
\hline & Totale populatie & 17 & nvt \\
\hline I & Geriatrisch Complex $(\mathrm{n}=307)$ & 15 & NS \\
II & Cardiaal $(\mathrm{n}=132)$ & 25 & $<0.05$ \\
III & Visusstoornissen $(\mathrm{n}=104)$ & 20 & NS \\
IV & Diabetes $(\mathrm{n}=177)$ & 19 & NS \\
V & Heupfraktuur $(\mathrm{n}=51)$ & 27 & NS \\
VI & Hypertensie $(\mathrm{n}=48)$ & 13 & NS \\
VII & Depressie $(\mathrm{n}=64)$ & 14 & NS \\
VIII & Anemie $(\mathrm{n}=104)$ & 14 & NS \\
\hline
\end{tabular}

t-Toets

Hieruit kunnen dezelfde konklusies getrokken worden als uit de analyse van de afzonderlijke diagnoses: voor het merendeel bestaat geen significante 
relatie. Uitsluitend cluster II (decompensatio cordis, atriumfibrilleren en myocardinfarct) komt significant vaker voor bij patiënten die overlijden. Verzorgingsproblematiek, onderdeel van cluster I (het Geriatrisch Complex) en als afzonderlijk probleem wel significant van invloed (zie boven), heeft na clustering niet langer een dermate invloed dat significantie wordt bereikt. Opvallend en konform de eerdere redenering is wel dat de mate van aanwezigheid van het Geriatrisch Complex geringer is bij de overleden patiënten dan bij de niet overleden patiënten.

Bij berekening van het relatieve overlijdensrisiko (tabel 7.2.4) blijft de konkiusie dezelfde, zij het dat ook cluster VI: heupfrakturen en decubitus, een significant verhoogd risiko op overlijden kent.

Tabel 7.2.4 Het relatieve overlijdensrisico (RR) van de onderzochte patiëntenpopulatie $(n=474)$ in relatie tot aanwezigheid van één of meerdere kenmerken van de 8 clusters.

\begin{tabular}{llll}
\hline & RR & $\begin{array}{l}95 \% \text { betrouwbaar- } \\
\text { heidsinterval }\end{array}$ \\
\hline I & Geriatrisch Complex & 0,64 & $0,39-1,03$ \\
II & Cardialal & 1,95 & $1,19-3,19$ \\
III & Visusstoornissen & 1,26 & $0,72-2,18$ \\
IV & Diabetes & 1,20 & $0,74-1,95$ \\
V & Heupfraktuur & 1,93 & $1,03-3,63$ \\
VI & Hypertensie & 0,65 & $0,27-1,58$ \\
VII & Depressie & 0,74 & $0,35-1,57$ \\
VIII & Anemie & 0,75 & $0,41-1,37$ \\
\hline
\end{tabular}

Wederom blijkt - net niet significant - dat aanwezigheid van elementen van het Geriatrisch Complex een positieve invloed heeft, blijkend uit het laagste overlijdensrisiko $(0.64-95 \%$ betrouwbaarheidsinterval $0.39-1,03)$ van de gehele groep.

De veronderstelling dat samenhangende diagnoses elkaar potentiëren ten aanzien van het overlijdensrisiko, wordt niet bevestigd. Dit is een additioneel argument voor het relatief geringe belang dat multiple ziektelast heeft voor de kans op overlijden.

\subsection{De relatie tussen het funktioneren bij opname en het overlijden}

Bij de analyse van funktioneringsparameters in relatie tot overlijden is om pragmatische redenen uitsluitend uitgegaan van de situatie bij opname. Het moment van overlijden is frequent onvoorzien, de situatie daaraan voorafgaand leent zich zelden voor analyse van zelfzorgparameters, het interval ten opzichte van het moment van de verzameling van opnamegegevens sterk 
wisselend. Uit tabel 7.3.1. en 7.3.2 blijkt dat patiënten die overlijden bij opname significant vaker bedlegerig zijn en/of een catheter hebben.

Tabei 7.3.1 Het percentuele verschil in overlijden op basis van het funktioneren bij opname van de onderzochte patiëntenpopulatie $(n=474)$.

\begin{tabular}{lcl}
\hline & $\begin{array}{l}\text { overlijdens- } \\
\text { percentage }\end{array}$ & p-waarde \\
\hline Totale populatie & 17 & nvt \\
\hline Bedlegerig & 28 & $<0.000$ \\
Catheter & 25 & $<0.05$ \\
ADL zelfstandig & 6 & $<0.05$ \\
ADL licht hulpbehoevend & 11 & $<0.05$ \\
ADL volledig afhankelijk & 21 & $=0.001$ \\
Zelfstandig mobiel & 9 & $<0.000$ \\
Mobiel met personele hulp & 13 & NS \\
Volledig incontinent & 12 & $<0.05$ \\
Soms incontinent & 18 & NS \\
Volledig incontinent & 16 & NS \\
\hline
\end{tabular}

l-Toets

Tabel 7.3.2. Het relatief overlijdensrisico (RR) in relatie tot funktioneren bij opname van de onderzochte patiëntenpopulatie $(n=474)$

\begin{tabular}{lll}
\hline & RR & $\begin{array}{l}95 \% \text { betrouwbaar- } \\
\text { heidsinterval }\end{array}$ \\
\hline Bedlegerigheid & 3,03 & $1,86-4,94$ \\
Catheter & 1,91 & $1,14-3,18$ \\
ADL zelfstandig & 0,31 & $0,07-1,31$ \\
ADL licht hulpbehoevend & 0,50 & $0,27-0,93$ \\
ADL volledig hulpbehoevend & 2,37 & $1,32-4,25$ \\
Zelfstandig mobiel & 0,39 & $0,21-0,71$ \\
Mobiel met personele hulp & 0,64 & $0,37-1,10$ \\
Niet incontinent & 0,55 & $0,31-0,95$ \\
Soms incontinent & 1,08 & $0,60-1,94$ \\
Volledig incontinent & 0,89 & $0,49-1,63$ \\
\hline
\end{tabular}

Volledige afhankelijkheid wat het ADL-funktioneren betreft is prognostisch ongunstig; de kleine groep die bij opname in beperkte mate ADL-afhankelijk is of volledig zelfstandig heeft, zoals wel enigszins te verwachten een significant geringer percentage overledenen. Niet bedlegerig zijn bij opname en/of volledig continent zijn is prognostisch eveneens gunstig. Het meesit uitgesproken is het verschil in bedlegerigheid. Voor een deel is dit waarschijnlijk. terug te voeren op de diagnoses CVA en decompensatio cordis. Het is denkbaar dat 
deze patiënten gedurende opname niet of moeilijk mobiliseerbaar zijn en als het ware de verklaring vormen voor het feit dat bij ontslag vrijwel alle patiënten (logischerwijs niet-overleden) in meer of mindere mate mobiel zijn. Voor zover deze funktionele parameters het produkt zijn van de aanwezige morbiditeit bevestigen deze gegevens althans ten dele de veronderstelling dat de ernst van de aandoening in termen van funktionele beperking belangrijker is dan de aandoening als zodanig.

\subsection{Multifaktoriële analyse van het overlijdensrisiko}

Uit de voorgaande bespreking is gebleken dat een groot aantal faktoren op zich geen relatie hebben met overlijden, terwijl van een aantal andere faktoren waarschijnlijk is gemaakt dat het met name de interaktie met andere elementen is die bepalend is voor de invloed op het overlijden.

Met behulp van logistische regressie kan nagegaan worden in hoeverre op grond van de onderzochte parameters een uitspraak gedaan kan worden over het uiteindelijk overlijdensrisiko. Bij vooranalyse, waarbij alle variabelen op hun significantie zijn onderzocht, blijken bedlegerigheid bij opname, catheter bij opname, de diagnose CVA en de clusters V, II en I relevante variabelen. Significante interaktie effekten zijn bedlegerigheid bij cluster II, cathetergebruik bij de diagnose CVA en de kombinatie CVA en cluster I (zie tabel 7.4.1.). Uit de uitkomsten blijkt dat met behulp van de gebruikte variabelen het niet-overlijden in $97 \%$ van de gevallen korrekt voorspeld kan worden: slechts 11 van de 391 overlevenden worden ten onrechte ingedeeld in de kategorie patiënten die zal komen te overlijden. Deze hoge specificiteit gaat echter gepaard met een lage sensitiviteit: van de 83 patiënten die wel overlijden worden er slechts 19 korrekt voorspeld ( $24 \%$ ).

De belangrijkste variabele om te voorspellen dat iemand niet zal overlijden is cluster I: het geriatrische complex. Dit is op grond van eerdere bevindingen niet verrassend, alhoewel juist het aanwezig zijn van dit cluster het meest typische kenmerk van de onderzochte patiëntengroep kan worden genoemd. Wel opvallend is dat de aanwezigheid van elementen van dit cluster in geval van CVA het verhoogde overlijdensrisiko zelfs in het tegendeel doet verkeren. Inhoudelijk gezien is dit echter niet verwonderlijk omdat de elementen waaruit dit cluster bestaat op zich niet gekenmerkt worden door een associatie met levensbedreigende situaties. Mogelijk geldt ook hier dat sprake is van een selektie-effekt: de kans dat een patiënte door huisarts of specialist benoemd wordt als geriatrische patiënt is recht evenredig met de aanwezigheid van elementen uit het Geriatrisch Complex en omgekeerd evenredig met de aanwezigheid van andere het leven direkt bedreigende aandoeningen. Dit leidt ertoe dat de "klassieke geriatrische patiënt" in de onderzoekspopulatie minder kans heeft te overlijden dan de geriatrische patiënt bij wie andere problemen meer op de voorgrond staan. Voortgaand op deze redenering zal gelden dat voor een deel van de CVA patiënten eerst nadat duidelijk is dat zij 
niet zullen overlijden geriatrische konsultatie wordt aangevraagd. Het aktief zijn van het probleem CVA in deze groep wordt waarschijnlijk meer bepaald door de aanwezigheid van blijvende beperkingen en handicaps dan door de bedreiging van vitale funkties.

Tabel 7.4.1 De voorspelling van al dan niet overlijden door middel van logistische regressie. Gewichten van significante hoofdeffecten en interakties. Voorselectie: o.a. alle funktioneringselementen en de 28 meest voorkomende diagnoses.

\begin{tabular}{|c|c|c|c|}
\hline Bron & $\beta$-gewicht & p-waarde & $\operatorname{Exp}(\beta)$ \\
\hline \multicolumn{4}{|l|}{ Hoofdeffecten } \\
\hline Bedlegerig bij opname & 0.90 & 0.01 & 2.45 \\
\hline Catheter bij opname & -0.35 & 0.34 & 0.71 \\
\hline CVA & 0.29 & 0.63 & 1.34 \\
\hline Cluster Heupfraktuur & 0.22 & 0.57 & 1.24 \\
\hline \multicolumn{4}{|l|}{ Cluster Atriumfibrilleren } \\
\hline één klacht & 0.44 & 0.32 & 1.55 \\
\hline$\geq$ twee klachten & 0.17 & 0.80 & 1.19 \\
\hline \multicolumn{4}{|c|}{ Cluster Geriatrisch Complex } \\
\hline één klacht & -0.45 & 0.89 & 0.96 \\
\hline z twee klachten & -0.78 & 0.05 & 0.45 \\
\hline \multirow{2}{*}{\multicolumn{4}{|c|}{ Interakties }} \\
\hline \multicolumn{2}{|c|}{ Bedlegerig-opname * Cluster Atriumfibrilleren } & & \\
\hline één klacht & 0.31 & 0.62 & 1.36 \\
\hline$\geq$ twee klachten & 1.26 & 0.17 & 3.51 \\
\hline Catheter-opname * CVA & 2.98 & 0.002 & 19.7 \\
\hline \multicolumn{4}{|c|}{ CVA * Cluster Geriatrisch Complex } \\
\hline één klacht & -2.23 & 0.04 & 0.11 \\
\hline$\geq$ twee klachten & -0.20 & 0.85 & 0.82 \\
\hline Konstante & -2.29 & 0.00 & - \\
\hline
\end{tabular}

Tabe! 7.4.2 De voorspelling van al dan niet overlijden door middel van logistische regressie: de voorspelling volgens het model uit tabel 7.4.1 en de feitelijke' uitkomst'.

\begin{tabular}{lrrrr}
\hline & \multicolumn{4}{l}{ Voorspelling overlijden } \\
\cline { 2 - 4 } & & nee & ja & correct voorspeld \\
\hline Overleden & - & 378 & 11 & $97 \%$ (specificiteit) \\
Totaal & + & 61 & 19 & $24 \%$ (sensitiviteit) \\
\hline
\end{tabular}

ontbrekend: niet overleden 2, overleden 3 
Is er - meer in het algemeen - wel sprake van een dergelijke bedreiging dan bestaat mogelijk minder de neiging de geriatrische symptomatologie (elementen uit het geriatrische complex) apart te benoemen. Hiermee kan verklaard worden dat het overlijdenspercentage van de groep onderzochte patiënten enerzijds hoog ligt $(17 \%)$ terwijl anderzijds toch de patiënten die het meest voldoen aan de criteria voor een geriatrische patiënt zich relatief gunstig onderscheiden. De geringe sensitiviteit is mogelijk mede te verklaren door het feit dat - zoals al eerder gekonstateerd - de gehanteerde diagnoses en problemen geen intrinsieke maat vormen voor de ernst van de situatie.

Uiteindelijk blijft het toch van belang dat met betrekkelijk grote zekerheid kan worden aangegeven op grond van de beschikbare gegevens welke patiënten niet zullen overlijden. Juist bij geriatrische patiënten is het van uitermate groot belang dat onderbouwd kan worden of het reaktiveren en voortbehandelen nog zinvol is in relatie tot de prognose quo ad vitam. 



\section{Hoofdstuk 8}

\section{De BOP en de GIP-schaal}

Bij het bepalen van de lichamelijke en psychische toestand van geriatrische patiënten wordt veelvuldig gebriik gemaakt van zgn. schalen. Twee bekende schalen die in Nederland gebruikt worden zijn de Beoordelingsschaal voor Oudere Patiënten (BOP) en de Gedragsobservatieschaal voor Intramurale Psychogeriatrie (GIP).

Ervaring met deze schalen is met name opgedaan in verpleeghuizen en psychogeriatrische afdelingen van psychiatrische ziekenhuizen.

Beide schalen zijn observatieschalen. Er wordt geen gebruik gemaakt van interviews of tests, wat als voordeel heeft dat de patiënt zelf aktief geen gegevens hoeft te verschaffen. De observatie vindt doorgaans plaats over een periode van twee weken en is niet afhankelijk, gelet op de aard van de items, van specifieke deskundigheid. Interaktie tussen de meting en patiëntgebonden faktoren als gedrag, vermoeidheid en afleidbaarheid treedt niet op.

De BOP-schaal, die oorspronkelijk ontwikkelt is voor verpleeghuisbewoners (v.d. Kam e.a. 1971) maakt wat betreft het toepassingsgebied geen onderscheid tussen somatische en psychogeriatrische patiënten. De totale observatieschaal bestaat uit 35 items, verdeeld over 6 subschalen. De verdeling van de items over deze 6 subschalen is relatief onevenwichtig, gelet op het feit dat 23 van de 35 items betrekking hebben op de subschaal "hulpbehoevendheid", terwijl de subschaal aggressiviteit bijvoorbeeld maar 5 items kent. Uit evaluatie is gebleken dat de schaal zoals te verwachten met name voldoet als het gaat om een globale meting van hulpbehoevendheid en in dit opzicht ook goed bruikbaar is in wetenschappelijk en beleidsgericht onderzoek (Diesfeldt 1980/81, Wimkens 1976,Verstraten 1987).

Ten opzichte van de BOP-schaal is de GIP-schaal meer specifiek gericht op gedragsproblematiek (Verstraten 1987). De GIP-schaal bestaat uit 14 subschalen. Deze zijn ontwikkeld op basis van een selektie uit een dertigtal gedragstypen, gegroepeerd rondom drie hoofditems, $\mathrm{nl}$. cognitieve stoornissen ( 8 schalen), psychomotore stoornissen ( 2 schalen) en emotionele stoornissen (4 schalen).

Evaluatie van het gebruik heeft plaatsgevonden in geriatrische afdelingen van psychiatrische ziekenhuizen, in psychogeriatrische afdelingen van verpleeghuizen en in psychogeriatrische dagbehandelingsplaatsen. Door de ontwerpers is verondersteld dat de schaal mogelijk ook geschikt zou zijn voor meer 
somatisch georiënteerde lokaties. De schaal is bruikbaar voor o.m. evaluatie van het funktioneren van patiënten in de tijd, het meten van behandelingsstrategieën en inschatting van de hulp- of begeleidingsbehoefte. Daarnaast is de schaal ook bruikbaar als instrument ter ondersteuning bij beslissingen inzake ontslag en plaatsing.

Gezien het feit dat het verblijf van geriatrische patiënten in een ziekenhuis van relatief korte duur is en veel aandacht en inspanning erop gericht is om ontslag naar elders mogelijk te maken is met name getracht de bruikbaarheid van beide schalen in dit verband na te gaan. Op de uitkomsten hiervan wordt ingegaan in dit hoofdstuk.

Achtereenvolgens is bij de onderzochte groep geriatrische patiënten onderzocht

- wat de uitkomsten zijn voor de totale populatie

- hoe de relatie is van beide schalen met basale kenmerken als leeftijd, geslacht en opnameduur

- hoe de uitkomsten van de schalen zich verhouden tot gegevens betreffende het ADL-funktioneren

- in hoeverre de betekenis van de schalen anders is voor specifieke subgroepen, te weten patiënten met één of meer kenmerken van het geriatrische complex en patiënten met een dementiesyndroom

- tenslotte wat de betekenis is van de schalen voor de ontslagrichting, voor de groep als geheel en onderscheiden subgroepen.

\subsection{De onderzoekspopulatie}

In de periode januari 1990 tot januari 1991 zijn de gegevens verzameld van 413 opeenvolgende patiënten die behandeld zijn volgens het FGB. De gegevensverzameling is gelijk aan de datacollectie van de eerder beschreven 646 patiënten. Voor het berekenen van de ADL-totaal score zijn de ADL-gegevens gedichitomiseerd naar wel of niet hulpafhankelijk. Hierbij is gebruik gemaakt van de indeling volgens Katz. Vervolgens zijn de scores per ADL-categorie (0 of 1) opgeteld, waarbij de eindscore 0 volledige ADL -onafhankelijkheid betekent en de score 5 volledige afhankelijkheid. Daarnaast is van alle patiënten na de eerste week van opname en in de week van ontslag een BOP-schaal en een GIP-schaal ingevuld. Deze beoordelingsschalen zijn steeds door dezelfde onderzoeker, die deel uitmaakte van het behandelteam, ingevuld.

Teneinde de gegevens zo optimaal mogelijk vergelijkbaar te laten zijn met de eerder gepresenteerde gegevens zijn vervolgens de gegevens bewerkt van de 293 patiënten die éénmalig zijn opgenomen en tijdens opname niet zijn overleden (zie figuur 1). 
Figuur 1 Verdeling patiënten naar heropnames en overlijden

\begin{tabular}{lccc}
\hline & 1e Opname & Heropname & Totaal \\
\hline Niet overleden & 293 & 57 & 350 \\
Wel overleden & 57 & 6 & 63 \\
Totaal. & 350 & 63 & 413 \\
\hline
\end{tabular}

De basale variabelen voor deze 293 patiënten zijn beschreven in tabel 8.1.1 Ten opzichte van de 646 eerder onderzochte patiënten bestaan geen significante verschillen.

Tabel 8.1.1 Vergelijking van de basale variabelen van de 293 patiënten uit het onderzoek van de BOP- en de GIP-schaal met de 646 patiënten uit het onderzoek van het Geriatrisch Complex.

\begin{tabular}{lcc}
\hline & $\mathrm{n}=293$ & $\mathrm{n}=646$ \\
\hline Vrouwen (\%) & 67 & 65 \\
Mannen (\%) & 33 & 35 \\
Woonsituatie (\%) & & \\
Zelfstandig & 63 & 63 \\
Bij familie & 11 & 10 \\
VZH & 24 & 24 \\
VPH & 1 & 2 \\
& & \\
Aantal diagnoses & & 5,7 \\
Gemiddeld & 4,5 & 5,0 \\
Mediaan & 4,0 & \\
& & 1 \\
Leeftijdsklassen & & 11 \\
$61-65$ jaar & 1 & 22 \\
66-70 & 5 & 31 \\
$71-75$ & 12 & 8 \\
$76-80$ & 20 & \\
$81-85$ & 30 & \\
$86-90$ & 24 & 20 \\
$>90$ & 9 & 8 \\
\hline
\end{tabular}

$V Z H=$ verzorgingstehuis; $V P H=$ verpleeghuis

Gegevens betreffende het funktioneren bij opname en ontslag zijn samengevat in tabel 8.1.2. Deze getallen verschillen niet significant van de eerder beschreven popuplatie. 
Tabel 8.1.2 Funktioneren bij opname en ontslag van de niet-overleden patiënten (percentages), bij wie onderzoek is gedaan naar de BOP- en de GIP-score, gedurende de eerste opname $(n=293)$

\begin{tabular}{|c|c|c|c|}
\hline & & $\begin{array}{l}\text { Opname } \\
(\%)\end{array}$ & $\begin{array}{l}\text { Ontslag } \\
(\%)\end{array}$ \\
\hline \multicolumn{2}{|l|}{ Bedlegerig } & 27 & 7 \\
\hline \multicolumn{2}{|l|}{ Catheter } & 17 & 7 \\
\hline ADL-totaal score & $=0$ & 31 & 54 \\
\hline & $=1$ & 15 & 15 \\
\hline & $=2$ & 5 & 7 \\
\hline & $=3$ & 15 & 9 \\
\hline & $=4$ & 16 & 6 \\
\hline & $=5$ & 17 & 9 \\
\hline \multicolumn{4}{|c|}{ Mobiliteit } \\
\hline \multicolumn{4}{|c|}{ (Patiënt niet bedlerig bij opname) } \\
\hline \multicolumn{2}{|c|}{ Zelfstandig } & 57 & 82 \\
\hline \multicolumn{2}{|l|}{ Personele hulp } & 43 & 15 \\
\hline \multicolumn{2}{|l|}{ Bedlegerig } & $=$ & 2 \\
\hline \multicolumn{4}{|c|}{ Incontinentie } \\
\hline \multicolumn{4}{|c|}{ (Patiënt zonder catheter bij opname) } \\
\hline & 21 & 27 \\
\hline & & 31 & 38 \\
\hline \multirow{2}{*}{\multicolumn{2}{|c|}{$\begin{array}{l}\text { frequent incontinent } \\
\text { catheter }\end{array}$}} & 50 & 28 \\
\hline & & - & 7 \\
\hline
\end{tabular}

\subsection{De BOP-score}

8.2.0 De scores van de totale onderzoekspopulatie op de BOP-schalen

De gemiddelde score van de totale onderzochte groep $(n=293)$ op de zes verschillende BOP-schalen bij opname en ontslag staat in tabel 8.2.0.1. 
Tabel 8.2.0.1 De groepsgemiddelden (inclusief standaarddeviatie) van de totale onderzochte patiëntengroep op de BOP-schalen bij opname en ontslag $(n=293)$.

\begin{tabular}{|c|c|c|c|c|c|c|}
\hline \multirow[b]{2}{*}{ BOP-schaal } & & \multicolumn{2}{|c|}{ opname } & \multicolumn{2}{|c|}{ ontslag } & \multirow[b]{2}{*}{ p-waarde } \\
\hline & & gem & sd & gem & sd & \\
\hline Hulpbehoevendheid & $(0-46)$ & 16,7 & 9,5 & 12,1 & 8,0 & $<0.000$ \\
\hline Agressiviteit & $(0-10)$ & 0,9 & 1,6 & 0,5 & 1,1 & $<0.000$ \\
\hline Lichamelijke invaliditeit & $(0-6)$ & 2,8 & 1,8 & 1,9 & 1,6 & $<0.000$ \\
\hline Depressief gedrag & $(0-6)$ & 2,0 & 1,7 & 1,4 & 1,4 & $<0.000$ \\
\hline Psychische invaliditeit & $(0-8)$ & 2,8 & 2,0 & 2,2 & 1,9 & $<0.000$ \\
\hline Inaktiviteit & $(0-14)$ & 8,9 & 3,5 & 7,0 & 3,3 & $<0.000$ \\
\hline
\end{tabular}

t-Toets

Opvallend is dat - ondanks de grote hulpbehoevendheid bij opname uitgedrukt in ADL-funktioneren, mobiliteit en incontinentie - de score op schaal 1: hulpbehoevendheid tegelijkertijd relatief laag is. Voorts blijkt schaal 2: aggresiviteit laag te scoren, wat misschien verklaard kan worden door het feit dat het gaat om patiënten met intercurrente aandoeningen, die vrijwel steeds met spoed in het ziekenhuis zijn opgenomen en daar relatief kort verblijven: de gedragskenmerken die benoemd worden in schaal 2 hebben onder de gegeven omstandigheden kennelijk weinig gelegenheid om tot expressie te komen c.q. geobserveerd te worden.

Van belang is voorts de konstatering dat de gemiddelde scores bij ontslag steeds significant lager zijn dan bij opname.

\subsubsection{BOP-score en leeftijd}

De relatie tussen de zes subschalen van de BOP-score en de leeftijd is onderzocht bij opname en ontslag (zie tabel 8.2.1.1A/B).

Tabel 8.2.1.1A Gemiddelde BOP-score bij opname per leeftijdscategorie ( $n=293)$

\begin{tabular}{llrrrrrrl}
\hline BOP-schaal & \multicolumn{9}{c}{ Leeftijd } & & & & \\
\cline { 3 - 7 } & & $66-70$ & $71-75$ & $76-80$ & $81-85$ & $86-90$ & $>90$ & p-waarde \\
\hline Hulpbehoevendheid & $(0-46)$ & 14,6 & 16,0 & 16,8 & 17,1 & 19,4 & 19,8 & NS \\
Agressiviteit & $(0-10)$ & 0,9 & 0,7 & 0,8 & 1,0 & 0,8 & 0,6 & NS \\
Lich. Invaliditeit & $(0-6)$ & 2,6 & 2,7 & 2,9 & 3,0 & 3,3 & 3,6 & NS \\
Depressief Gedrag & $(0-6)$ & 3,0 & 2,2 & 2,4 & 2,1 & 1,9 & 1,4 & $<0,01$ \\
Psych. Invaliditeit & $(0-8)$ & 2,2 & 2,5 & 2,7 & 2,7 & 3,5 & 3,2 & $<0,05$ \\
Inaktiviteit & $(0-14)$ & 8,0 & 8,5 & 9,3 & 9,2 & 9,7 & 9,8 & NS \\
\hline
\end{tabular}


Tabel 8.2.1.1B Gemiddelde BOP-score bij ontslag per leeftijdscategorie $(n=293)$

\begin{tabular}{llrrrrrrl}
\hline BOP-schaal & \multicolumn{9}{c}{ Leeftijd } & & \\
\cline { 3 - 7 } & & $66-70$ & $71-75$ & $76-80$ & $81-85$ & $86-90$ & $>90$ & p-waarde \\
\hline Hulpbehoevendheid & $(0-46)$ & 10,5 & 12,2 & 11,8 & 11,5 & 13,5 & 14,5 & NS \\
Agressiviteit & $(0-10)$ & 0,5 & 0,6 & 0,6 & 0,3 & 0,6 & 0,3 & NS \\
Lich. Invaliditeit & $(0-6)$ & 1,7 & 1,9 & 1,8 & 1,7 & 2,2 & 2,6 & NS \\
Depressief Gedrag & $(0-6)$ & 2,7 & 1,5 & 1,7 & 1,4 & 1,1 & 1,0 & $<0.000$ \\
Psych. Invaliditeit & $(0-8)$ & 1,8 & 2,1 & 1,8 & 2,1 & 2,7 & 2,4 & NS \\
Inaktiviteit & $(0-14)$ & 6,3 & 7,0 & 7,5 & 6,7 & 7,6 & 8,0 & NS \\
\hline
\end{tabular}

\section{ANOVA}

Er bestaat bij opname een positieve relatie met subschaal 5 (psychische invaliditeit) en een negatieve relatie met subschaal 4 (depressief gedrag). De overige vier schalen hebben geen significante relatie met de leeftijd. Bij ontslag bestaat uitsluitend een negatieve significante relatie tussen de leeftijd en subschaal 4 (depressief gedrag). Uit eerder gememoreerd onderzoek is al duidelijk geworden dat de BOP-schaal de psychische funkties minder valide meet dan de meer lichamelijke funkties. In hoeverre de hier gevonden uitkomst dit reflecteert is de vraag. Een mogelijke verklaring kan ook zijn dat bij hoogbejaarden organiciteit meer op de voorgrond staat, waardoor depressief gedrag minder wordt onderkend danwel gescoord. De hogere score op psychische invaliditeit bij opname kan wijzen op het feit dat hoogbejaarden frequenter delirante verschijnselen vertonen bij intercurrente aandoeningen die ziekenhuisopname noodzakelijk maken. Dit verklaart dan tevens waarom deze significantie bij ontslag niet langer aanwezig is. Een additioneel argument voor deze hypothese is het feit dat de gemiddelde score van alle leeftijdsgroepen bij ontslag zich bevindt op het niveau van de jongste categorieën bij opname.

\subsubsection{BOP-score en geslacht}

Zowel bij opname als bij ontslag bestaat er een significant verschil in de score van subschaal 2 (agressiviteit) tussen mannen en vrouwen: mannen in de onderzochte populatie zijn kennelijk agressiever of worden agressiever gevonden (tabel 8.2.2.1A/B). De overige scores zijn voor beide geslachten niet significant verschillend. 
Tabel 8.2.2.1A Gemiddelde BOP-scores bij vrouwen $(n=196)$ en mannen $(n=97)$.

\begin{tabular}{llccl}
\hline BOP-schaal & & vrouwen & mannen & p-waarde \\
\hline Hulpbehoevendheid & $(0-46)$ & 17,2 & 18,4 & NS \\
Agressiviteit & $(0-10)$ & 0,7 & 1,2 & $<0.05$ \\
Lich. Invaliditeit & $(0-6)$ & 3,0 & 3,2 & NS \\
Depressief Gedrag & $(0-6)$ & 2,2 & 2,0 & NS \\
Psych.Invaliditeit: & $(0-8)$ & 2,9 & 2,9 & NS \\
Inaktiviteit & $(0-14)$ & 9,1 & 9,6 & NS \\
\hline
\end{tabular}

\section{t-toets}

Tabel 8.2.2.1B Gerniddelde BOP-scores bij vrouwen $(\hat{n}=196)$ en mannen $(\boldsymbol{n}=97)$ bij ontslag.

\begin{tabular}{llccl}
\hline BOP-schaal & & Vrouwen & Mannen & p-waarde \\
\hline Hulpbehoevendheid & $(0-46)$ & 12,1 & 12,7 & NS \\
Agressiviteit & $(0-10)$ & 0,4 & 0,7 & $=0.05$ \\
Lich. Invaliditeit & $(0-6)$ & 1,9 & 2,0 & NS \\
Depressief Gedrag & $(0-6)$ & 1,5 & 1,4 & NS \\
Psych.Invaliditeit & $(0-8)$ & 2,2 & 2,0 & NS \\
Inaktiviteit & $(0-14)$ & 6,9 & 7,7 & NS \\
\hline
\end{tabular}

t-toets

\subsubsection{BOP-score en mediane opnameduur}

Patiënten in de onderzoekspopulatie (tabel 8.2.3.1) die uiteindelijk langer dan de mediane opnameduur in het ziekenhuis verblijven scoren bij opname significant hoger op de subschalen 3 (lichamelijke invaliditeit) en 4 (depressief gedrag).

Deze relatie wordt bij ontslag niet meer gevonden. Dit kan inhouden dat de determinanten die tot een hogere score leiden weliswaar een relatief lange opname veroorzaken maar gedurende opname reversibel c.q. behandelbaar blijken. 
Tabel 8.2.3.1 De BOP-scores bij opname en ontslag uitgesplitst naar patiënten die korter (153) en langer (140) dan de mediane opnameduur zijn behandeld.

\begin{tabular}{|c|c|c|c|c|c|c|c|}
\hline \multirow[b]{3}{*}{ Hulpbehoevendheid } & \multirow[b]{3}{*}{$(0-46)$} & \multicolumn{3}{|c|}{ Opnanne } & \multicolumn{3}{|c|}{ Ontslag } \\
\hline & & \multicolumn{2}{|c|}{$\leq$ mediaan $>$} & \multirow{2}{*}{$\begin{array}{l}\text { p-waarde } \\
\text { NS }\end{array}$} & \multicolumn{2}{|c|}{$\leq$ mediaan $>$} & \multirow{2}{*}{$\begin{array}{l}\text { p-waard } \\
\text { NS }\end{array}$} \\
\hline & & 16,7 & 18,4 & & 12,3 & 12,2 & \\
\hline Agressiviteit & $(0-10)$ & 0,9 & 0,8 & NS & 0,6 & 0,4 & NS \\
\hline Lich. Invaliditeit & $(0-6)$ & 2,8 & 3,3 & $<0.05$ & 1,8 & 2,1 & NS \\
\hline Depressief Gedrag & $(0-6)$ & 1,9 & 2,3 & $<0.05$ & 1,5 & 1,5 & NS \\
\hline Psych.Invaliditeit & $(0-8)$ & 2,7 & 3,1 & NS & 2,1 & 2,2 & NS \\
\hline Inaktiviteit & $(0-14)$ & 9,1 & 9,3 & NS & 7,3 & 7,0 & NS \\
\hline
\end{tabular}

t-toets

\subsubsection{BOP-score en $A D L$-funktioneren}

De items zoals gescoord in de BOP-schalen berusten voor een deel op waarnemingen betreffende het ADL-funktioneren. Verwacht mag worden dat er een relatie bestaat tussen beiden. Wanner de vijf afzonderlijke ADL-funkties gecorreleerd worden aan de zes BOP-schalen (tabel 8.2.4.1) ontstaat een tamelijk homogeen correlatiepatroon. In volgorde van hoogte van correlatie coëfficient worden significante correlaties gevonden tussen de BOP-schalen 3,1,6 en 5 met het ADL-funktioneren.

Deze correlaties zijn per BOP-schaal duidelijk homogeen. De correlatie coëfficienten zijn verhoudingsgewijs hoog, wat erop kan wijzen dat het ADLfunktioneren voor de schalen 3,1,6 en 5 in belangrijke mate bepalend is. De samenhang bij ontslag is in essentie dezelfde als de samenhang bij opname. Ervan uitgaande dat het bepalen van het ADL-funktioneren minder omslachtig is en door het beperkte aantal items (keuzemogelijkheden) minder gevoelig is voor observatiefouten kan de vraag gesteld worden in hoeverre de BOP-score meer informatie biedt dan de ADL-score over de mate van hulpbehoevendheid c.q. de zorgbehoefte van de patiënten.

De hoge correlatie van de schalen $3,1,6$ en 5 met het ADL-funktioneren wordt bevestigd door de significante verschillen in uitkomsten van de gemiddelde scores in de BOP-schalen, getoetst per gedichitomiseerde ADL-categorie (tabel 8.2.4.2).

\subsubsection{BOP-scores en het geriatrische complex}

De BOP-scores worden met name geschikt geacht voor het beoordelen van de globale hulpbehoevendheid. Daar gebleken is dat bij patiënten met elementen van het Geriatrisch Complex de hulpbehoevendheid significant groter is dan bij patiënten zonder dergelijke problematiek mag verondersteld worden dat 
Tabel 8.2.4.1 Correlatie tussen de BOP-score per schaal en de ADL-funkties (gedichotomiseerd) bij opname en ontslag $(n=293)$.

\begin{tabular}{|c|c|c|c|c|c|}
\hline \multirow[t]{2}{*}{ BOP-schalen } & \multicolumn{5}{|c|}{ ADL-funkties bij opname } \\
\hline & wassen & kleden & toilet & in/uit bed & eten \\
\hline Hulpbehoevendheid $(0-46)^{*}$ & 0.67 & 0.66 & 0.67 & 0.58 & 0.71 \\
\hline Agressiviteit $(0-10)^{* *}$ & 0.09 & 0.08 & 0.01 & -0.02 & 0.03 \\
\hline Lich. Invaliditeit $(0-6)^{*}$ & 0.78 & 0.79 & 0.80 & 0.77 & 0.62 \\
\hline Depressief Gedrag $(0-6)^{* *}$ & -0.02 & 0.01 & 0.05 & 0.08 & -0.04 \\
\hline Psych. Invaliditeit $(0-8)^{*}$ & 0.44 & 0.43 & 0.46 & 0.35 & 0.56 \\
\hline \multirow[t]{3}{*}{ Inaktiviteit $(0-14)^{3 *}$} & 0.65 & 0.65 & 0.62 & 0.52 & 0.56 \\
\hline & \multicolumn{5}{|c|}{ ADL funkties bij ontslag } \\
\hline & wassen & kleden & toile! & in/uit bed & eten \\
\hline Hulpbehoevendheid $(0-46)^{*}$ & 0.71 & 0.71 & 0.73 & 0.61 & 0.65 \\
\hline Agressiviteit $(0-10)^{* *}$ & 0.05 & 0.06 & -0.06 & -0.06 & -0.02 \\
\hline Lich. Invaliditeit $(0-6)^{*}$ & 0.75 & 0.78 & 0.82 & 0.77 & 0.60 \\
\hline Depressief Gedrag $(0-6)^{*+*}$ & -0.02 & -0.01 & 0.07 & 0.14 & 0.01 \\
\hline Psych. Invaliditeit $(0-8)^{*}$ & 0.52 & 0.51 & 0.54 & 0.36 & 0.44 \\
\hline Inaktiviteit $(0-14)^{*}$ & 0.66 & 0.65 & 0.62 & 0.52 & 0.53 \\
\hline
\end{tabular}

Pearson's correlatie coëfficient; ${ }^{*}$ alle p-waarden $<0.000 ;{ }^{* *}$ NS; ${ }^{* * *}$ NS m.u.v. in/uit bed $p<0.01$

Tabel 8.2.4.2 Gemiddelde ADL-score per gedichotomiseerde ADL-test $(0=$ onafhankelijk, $1=$ afhankelijk) $(n=293)$.

\begin{tabular}{|c|c|c|c|c|c|c|c|c|c|c|}
\hline \multirow[t]{3}{*}{ BOP-schaal } & \multicolumn{10}{|c|}{ ADL-funktie } \\
\hline & \multicolumn{2}{|c|}{ wassen } & \multicolumn{2}{|c|}{ kleden } & \multicolumn{2}{|c|}{ toilet } & \multicolumn{2}{|c|}{ in/uit bed } & \multirow{2}{*}{$\begin{array}{c}\text { eten } \\
0\end{array}$} & \multirow[b]{2}{*}{1} \\
\hline & 0 & 1 & 0 & 1 & 0 & 1 & 0 & 1 & & \\
\hline Hulpbehoevendheid* & 10,6 & 23,4 & 10,8 & 23,3 & 8,4 & 20,7 & 14,0 & 24,9 & 12,7 & 25,6 \\
\hline Agressiviteit** & 0,7 & 0,9 & 0,8 & 0,9 & 0,7 & 0,9 & 0,9 & 0,8 & 0,8 & 0,9 \\
\hline Lich. Invaliditeit* & 1,6 & 4,3 & 1,6 & 4,3 & 0,9 & 3,8 & 2,3 & 4,6 & 2,2 & 4,4 \\
\hline Depresșief Gedrag** & 2,1 & 2,1 & 2,1 & 2,2 & 2,0 & 2,2 & 2,0 & 2,4 & 2,2 & 2,0 \\
\hline Psych. Invaliditeit* & 1,9 & 3,7 & 2,0 & 3,7 & 1,6 & 3,3 & 2,4 & 3,9 & 2,1 & 4,2 \\
\hline Inaktiviteit* & 6,8 & 11,2 & 6,9 & 11,2 & 5,8 & 10,4 & 8,2 & 11,4 & 7,8 & 11,7 \\
\hline
\end{tabular}

t-toets; * alle p-waarden $<0.000 ; *$ NS

de BOP-scores van beide genoemde patiëntengroepen verschillend zijn (met name de schalen "hulpbehoevendheid" en "lichamelijke invaliditeit"). Van de 293 patiënten zijn er $105(36 \%)$ zonder en $188(64 \%)$ met elementen uit het Geriatrisch Complex. 
Uit tabel 8.2.5.1 en 8.2.5.2 blijkt dat zowel bij opname als bij ontslag significante verschillen gevonden worden in de gemiddelde groepscore op 5 van de 6 BOP-schalen. Patiënten met het Geriatrisch Complex scoren slechter wat betreft "hulpbehoevendheid, lichamelijke invaliditeit, psychische invaliditeit en inaktiviteit".

Tabel 8.2.5.1 Gemiddelde BOP-scores van patiënten met elementen uit het Geriatrisch Complex (GC) $(n=188)$ en patiënten zonder dergelijke kenmerken $(n=105)$ bij opname.

\begin{tabular}{lllll}
\hline BOP-schaal & & $\begin{array}{l}\text { Patiënt zonder } \\
\text { Geriatrisch } \\
\text { Complex }\end{array}$ & $\begin{array}{l}\text { Patiënt met } \\
\text { Geriatrisch } \\
\text { Complex }\end{array}$ & p-waarde \\
\hline Hulpbehoevendheid & $(0-46)$ & 13,2 & 18,6 & $<0.000$ \\
Agressiviteit & $(0-10)$ & 0,7 & 1,0 & NS \\
Lich.Invaliditeit & $(0-6)$ & 2,5 & 3,0 & $<0.05$ \\
Depressief Gedrag & $(0-6)$ & 2,5 & 1,8 & $<0.000$ \\
Psych.Invaliditeit & $(0-8)$ & 1,9 & 3,3 & $<0.000$ \\
Inaktiviteit & $(0-14)$ & 8,1 & 9,5 & $<0.01$ \\
\hline
\end{tabular}

ANOVA

Tabel 8.2.5.2 Gemiddelde BOP-scores van patiënten met elementen uit het Geriatrisch Complex (GC) $(n=188)$ en patiënten zonder dergelijke kenmerken ( $n=105)$ bij ontslag.

\begin{tabular}{lllll}
\hline BOP-schaal & & $\begin{array}{l}\text { Patiënt zonder } \\
\text { Geriatrisch } \\
\text { Complex }\end{array}$ & $\begin{array}{l}\text { Patiënt met } \\
\text { Geriatrisch } \\
\text { Complex }\end{array}$ & p-waarde \\
\hline Hulpbehoevendheid & $(0-46)$ & 8,7 & 13,8 & $<0.000$ \\
Agressiviteit & $(0-10)$ & 0,4 & 0,5 & NS \\
Lich.Invaliditeit & $(0-6)$ & 1,6 & 2,1 & $<0.05$ \\
Depressief Gedrag & $(0-6)$ & 1,7 & 1,3 & $<0.05$ \\
Psych.Invaliditeit & $(0-8)$ & 1,2 & 2,7 & $<0.000$ \\
Inaktiviteit & $(0-14)$ & 5,9 & 7,7 & $<0.000$ \\
\hline
\end{tabular}

ANOVA

Op de schaal "agressiviteit" worden geen verschillen gevonden en de scores zijn (schaalbreedte 0-10) zeer laag in beide groepen. Op de schaal "depressief gedrag" blijken patiënten met elementen van het Geriatrisch Complex beter te scoren dan de overige patiënten. Al eerder is gebleken dat depressieve patiënten zich onderscheiden in de totale patiëntengroep. Denkbaar is dat depressieve verschijnselen een pseudo-geriatrisch beeld oproepen bij oudere patiënten, maar dat dergelijke patiënten feitelijk niet thuishoren in de groep, gelet op hun funktioneringskenmerken en het onderscheid in diagnoses, behandeluitkomsten en ontslagrichting. Deze redenering vertoont enige analogie met het begrip "pseudo-dementie" als verschijningsvorm van depressie 
bij ouderen. De verschillen in groepsgemiddelden per schaal bij opname en ontslag zijn niet anders voor de patiënten met elementen van het Geriatrisch Complex dan voor degenen zonder dergelijke elementen.

\subsubsection{BOP-scores en het dementiesyndroom}

Er zijn 98 patiënten die voldoen aan de criteria van het dementiesyndroom (één van de specifieke elementen van het Geriatrisch Complex). Deze patiënten zijn vergeleken met de overige patiënten in de onderzochte groep. Patiënten met overige cognitieve stoornissen en depressies zijn hierbij uitgesloten om overlap te voorkomen, zodat uiteindelijk 121 niet-demente patiënten overblijven ter vergelijking. Uit tabel 8.2.6.1 en 8.2.6.2 blijkt dat zowel bij opname als ontslag de scores significant verschillen.

Tabel 8.2.6.1 Gemiddelde BOP-scores bij opname van patiënten met een dementie-syndroom $(n=98)$ in vergelijking met patiënten zonder dementie-syndroom, gecorrigeerd voor overige cognitieve stoornissen en depressie $(\mathbf{n}=121)$.

\begin{tabular}{lllll}
\hline BOP-schaal & & Patiënt met & \multicolumn{2}{c}{ Patiënt zonder } \\
dementie & dementie & p-waarde \\
\hline Hulpbehoevendheid & $(0-46)$ & 21,5 & 12,8 & $<0.0000$ \\
Agressiviteit & $(0-10)$ & 1,2 & 0,6 & $<0.01$ \\
Lich.Invaliditeit & $(0-6)$ & 3,0 & 2,7 & NS \\
Depressief Gedrag & $(0-6)$ & 1,3 & 2,5 & $<0.0000$ \\
Psych.Invaliditeit & $(0-8)$ & 4,4 & 1,7 & $<0.0000$ \\
Inaktiviteit & $(0-14)$ & 9,9 & 7,9 & $<0.0000$ \\
\hline
\end{tabular}

\section{ANOVA}

Tabel 8.2.6.2 Gemiddelde BOP-scores bij ontslag van patiënten met een dementie-syndroom ( $n=98)$ in vergelijking met patiënten zonder dementie-syndroom, gecorrigeerd voor overige cognitieve stoornissen en depressie $(n=121)$.

\begin{tabular}{lllll} 
BOP-schaal & & Patiënt met & \multicolumn{2}{l}{ Patiënt zonder } \\
& & dementie & dementie & p-waarde \\
\hline Hulpbehoevendheid & $(0-46)$ & 17,0 & 9,0 & $<0.0000$ \\
Agressiviteit & $(0-10)$ & 0,7 & 0,3 & $<0.05$ \\
Lich.Invaliditeit & $(0-6)$ & 2,2 & 1,7 & $<0.05$ \\
Depressief Gedrag & $(0-6)$ & 0,9 & 1,8 & $<0.0000$ \\
Psych.Invaliditeit & $(0-8)$ & 3,8 & 1,6 & $<0.0000$ \\
Inaktiviteit & $(0-14)$ & 9,2 & 6,4 & $=0.0001$ \\
\hline
\end{tabular}

ANOVA

Dit geldt zowel voor de schalen die meer specifiek op gedragsstoornissen gericht zijn ( 2,4 en 5$)$ als voor de overige schalen. Kennelijk is in de onderzoch- 
Tabel 8.2.7.1 De betekenis van de BOP-scores bij opname voor de ontslagrichting ( $\mathrm{n}=293$ ) onderscheiden worden: zelfstandige woonsituatie $(\mathrm{ZW})$, verzorgingstehuis $(\mathrm{VZH})$ en verpleeghuis (VPH).

\begin{tabular}{|c|c|c|c|c|c|}
\hline BOP-schaal & & $\begin{array}{l}Z W \\
n=144\end{array}$ & $\begin{array}{l}V Z H \\
n=83\end{array}$ & $\begin{array}{l}\text { VPH } \\
n=66\end{array}$ & p-waarde \\
\hline Hulpbehoevendheid & $(0-46)$ & 13,6 & 18,8 & 21,7 & $<0.0000$ \\
\hline Agressiviteit & $(0-10)$ & 0,8 & 0,7 & 1,0 & NS \\
\hline Lich.Invaliditeit & $(0-6)$ & 2,4 & 2,9 & 4,2 & $<0.0000$ \\
\hline Depressief Gedrag & $(0-6)$ & 2,0 & 2,0 & 2,3 & NS \\
\hline Psych.invaliditeit & $(0-8)$ & 2,3 & 3,4 & 3,3 & $<0.0000$ \\
\hline Inaktiviteit & $(0-14)$ & 7,9 & 9,5 & 10,6 & $<0.0000$ \\
\hline
\end{tabular}

ANOVA

Tabel 8.2.7.2 De betekenis van de BOP-scores bij ontslag voor de ontslagrichting $(\mathbf{n}=293$ ) onderscheiden worden: zelfstandige woonsituatie (ZW), verzorgingstehuis (VZH) en verpleeghuis (VPH).

\begin{tabular}{|c|c|c|c|c|c|}
\hline BOP-schaal & & $\begin{array}{l}Z W \\
n=144\end{array}$ & $\begin{array}{l}\mathrm{VZH} \\
\mathrm{n}=83\end{array}$ & $\begin{array}{l}\text { VPH } \\
\mathrm{n}=66\end{array}$ & p-waarde \\
\hline Hulpbehoevendheid & $(0-46)$ & 9,5 & 13,8 & 16,0 & $<0.0000$ \\
\hline Agressiviteit & $(0-10)$ & 0,4 & 0,4 & 0,6 & NS \\
\hline Lich.Invaliditeit & $(0-6)$ & 1,3 & 2,1 & 3,2 & $<0.0000$ \\
\hline Depressief Gedrag & $(0-6)$ & 1,4 & 1,2 & 1,9 & NS \\
\hline Psych.Invaliditeit & $(0-8)$ & 1,7 & 2,8 & 2,5 & $<0.0001$ \\
\hline Inaktiviteit & $(0-14)$ & 6,3 & 7,2 & 9,0 & $<0.0000$ \\
\hline
\end{tabular}

ANOVA

Tabel 8.2.7.3 De correlatie van de BOP-scores bij opname en ontslag ( $n=293$ ).

\begin{tabular}{llll}
\hline BOP-schaal & & R & P-waarde \\
\hline Hulpbehoevendheid & $(0-46)$ & 0.80 & $<0.000$ \\
Agressiviteit & $(0-10)$ & 0.64 & $<0.000$ \\
Lich.Invaliditeit & $(0-6)$ & 0.72 & $<0.000$ \\
Depressief Gedrag & $(0-6)$ & $0.7 !$ & $<0.000$ \\
Psych.Invaliditeit & $(0-8)$ & 0.86 & $<0.000$ \\
Inaktiviteit & $(0-14)$ & 0.72 & $<0.000$ \\
\hline
\end{tabular}

Pearson's correlatie coéfficient 
te patiëntengroep de aanwezigheid van dementiële problematiek ook sterk van invloed op het lichamelijk funktioneren. Dit kan erop wijzen dat de betreffende patiënten een ver gevorderd stadium van dementie hebben.

Uit de inschalingssystematiek volgens Reisberg bijvoorbeeld blijkt dat juist deze patiënten veelal ook. lichamelijk verschijnselen vertonen (Global Dementia Scale 6 en 7).

\subsubsection{BOP-scores en ontslagrichting}

Uit tabel 8.2.7.1 en 8.2.7.2 blijkt dat er - wederom voor de schalen 1,3,5 en 6 een significante relatie bestaat tussen de BOP-scores en de oritslagrichting. Voor de genoemde vier schalen geldt dat een hogere score een 'zwaardere' verzorgingssituatie betekent. De BOP-scores bij opnarne zijn gemiddeld steeds hoger dan bij ontslag maar de relatie blijft dezelfde. De correlatie tussen BOP-scores bij opname en ontslag is dan ook hoog (tabel 8.2.7.3). Op grond van bovenstaande bevindingen kan geconcludeerd worden dat de BOP-score bij opname, ondanks veranderingen die optreden gedurende opname, bruikbaar is als instrument om een inschatting te maken van de ontslagrichting van de patiënt.

\subsubsection{BOP-scores - resumé}

Uit de beschreven onderzoeksgegevens blijkt dat de waarde van de BOP-scores in relatie tot andere parameters niet voor alle schalen even consistent is. Met name de schalen van agressiviteit en depressief gedrag correleren slecht met de onderzochte parameters.

De schalen zijn goeddeels onafhankelijk van leeftijd en geslacht. Veranderingen in het ADL-funktioneren correleren goed met veranderingen in de BOPscore. Patiënten met dementie scoren op alle schalen slechter dan de overige niet-demente patiënten. De ontslagrichting is op grond van de BOP-score bij opname reeds redelijk in te schatten.

De betekenis van de BOP-score lijkt al met al groter voor somatische aspecten van het funktioneren dan voor meer specifieke - psychiatrische - aspecten als agressiviteit en depressiviteit.

\subsection{De GIP-score}

8.3.0 De gemiddelde scores van de totale onderzoekspopulatie op de GIP-schalen

De gemiddelde scores van de totale onderzoekspopulatie bij opname en ontslag zijn vermeld in tabel 8.3.0.1. 
Tabel 8.3.0.1 De gemiddelde scores op de 14 GIP-schalen (inclusief standaarddeviatie) van de onderzochte patiëntengroep $(n=293)$ bij opname en ontslag.

\begin{tabular}{|c|c|c|c|c|c|c|}
\hline \multirow[t]{2}{*}{ GIP-schaal } & & \multicolumn{2}{|c|}{ opname } & \multicolumn{2}{|c|}{ ontslag } & \multirow[b]{2}{*}{ p-waarde } \\
\hline & & gem. & sd & gem. & sd & \\
\hline Asociaal gedrag & $(0-18)$ & 6,8 & 3,9 & 5,6 & 3,4 & $<0.000$ \\
\hline Bewustzijnsstoornissen & $(0-21)$ & 3,4 & 3,6 & 2,1 & 2,6 & $<0.000$ \\
\hline Decorumverlies & $(0-15)$ & 4,7 & 3,7 & 3,5 & 3,1 & $<0.000$ \\
\hline Opstandig gedrag & $(0-15)$ & 2,4 & 3,5 & 1,8 & 2,8 & $<0.000$ \\
\hline Incoherent gedrag & $(0-15)$ & 2,6 & 3,0 & 1,7 & 2,4 & $<0.000$ \\
\hline Geheugenstoornissen & $(0-21)$ & 8,3 & 5,1 & 7,0 & 4,9 & $<0.000$ \\
\hline Desoriëntatie & $(0-15)$ & 4,3 & 3,8 & 3,7 & 3,6 & $<0.000$ \\
\hline Repetitief gedrag & $(0-15)$ & 1,7 & 2,7 & 1,3 & 2,2 & $<0.000$ \\
\hline Rusteloos gedrag & $(0-15)$ & 2,3 & 3,0 & 1,9 & 2,7 & $<0.000$ \\
\hline Achterdochtig gedrag & $(0-21)$ & 1,8 & 3,2 & 1,1 & 2,1 & $<0.000$ \\
\hline Zwaarmoedigheid & $(0-18)$ & 3,3 & 3,6 & 2,3 & 2,8 & $<0.000$ \\
\hline Afhankelijk gedrag & $(0-15)$ & 2,6 & 2,8 & 1,8 & 2,1 & $<0.000$ \\
\hline Angstig gedrag & $(0-18)$ & 0,4 & 1,4 & 0,2 & 0,7 & $<0.000$ \\
\hline
\end{tabular}

Tabel 8.3.0.2 De verdeling van de schaalscores voor psychogeriatrische verpleeghuisbewoners $(n=100-256)$ volgens Verstraten (1987).

\begin{tabular}{lllll}
\hline GIP-schaal & & $\begin{array}{l}\text { Aantal } \\
\text { patiënten }\end{array}$ & Gem. score & sd \\
\hline Asociaal gedrag & $(0-24)$ & 213 & 11,2 & 5,4 \\
Apathisch gedrag & $(0-18)$ & 255 & 9,6 & 4,3 \\
Bewustzijnsstoornissen & $(0-21)$ & 256 & 7,5 & 4,8 \\
Decorumverlies & $(0-15)$ & 246 & 6,1 & 3,9 \\
Opstandig gedrag & $(0-15)$ & 234 & 5,1 & 2,8 \\
Incoherent gedrag & $(0-15)$ & 220 & 5,4 & 3,8 \\
Geheugenstoornissen & $(0-21)$ & 220 & 11,6 & 5,1 \\
Desoriëntatie & $(0-15)$ & 237 & 5,4 & 2,9 \\
Repetitief gedrag & $(0-15)$ & 100 & 3,6 & 3,5 \\
Rusteloos gedrag & $(0-15)$ & 215 & 4,6 & 3,1 \\
Achterdochtig gedrag & $(0-21)$ & 224 & 3,0 & 3,9 \\
Zwaarmoedigheid & $(0-18)$ & 100 & 4,2 & 4,0 \\
Afhankelijk gedrag & $(0-15)$ & 100 & 4,7 & 3,4 \\
Angstig gedrag & $(0-18)$ & 113 & 2,9 & 3,5 \\
\hline
\end{tabular}


Over het geheel genomen zijn de scores relatief laag. Uitzondering vormen de schalen van asociaal gedrag, apathisch gedrag en geheugenstoornissen, die gemiddeld boven éénderde van de bandbreedte van de schaal komen. Ook hier kunnen aspekten als korte observatietijd, acute opname o.b.v. intercurrente ziekte en observatievermogen een rol spelen.

Konform de bevindingen bij de BOP zijn de scores bij ontslag steeds significant lager dan de scores bij opname.

Vergelijking met de schaalscores van psychogeriatrische verpleeghuisbewoners uit het onderzoek van Verstraten e.a. (1987) tabel 8.3.0.2 laat zien dat met uitzondering van de schaal voor zwaarmoedig en verdrietig gedrag geriatrische patiënten in het ziekenhuis steeds lager scoren. De variabiliteit in de groep, uitgedrukt in standaarddeviatie, is niet wezenlijk verschillend. Feitelijk is de vergelijking weinig betekenisvol, gelet op het feit dat de homogeniciteit van beide groepen wezenlijk verschilt: vergeleken worden geriatrische patiënten, waaronder $\pm 10 \%$ toekomstige psychogeriatrische verpleeghuisbewoners, met uitsluitend psychogeriatrische verpleeghuisbewoners.

\subsubsection{GIP-score en leeftijd}

Uit tabel 8.3.1.1 blijkt dat geheugenstoornis een positieve en zwaarmoedigheid een negatieve relatie heeft met de leeftijd. Voor geheugenstoornis wordt deze significantie alleen bij opname gevonden. De overige subschalen worden niet significant beïnvloed door de leeftijd. De negatieve relatie met zwaarmoedigheid (= depressiviteit) is conform eerdere bevindingen (zie o.a. BOP-score).

Tabel 8.3.1.1 De gemiddelde GIP-scores per schaal en per leeftijdscategorie $(n=293)$ bij opname en ontslag.

\begin{tabular}{|c|c|c|c|c|c|c|c|}
\hline \multirow[t]{2}{*}{ GIP-schaal } & \multicolumn{6}{|l|}{ leeftijd } & \multirow[b]{2}{*}{ p-waarde } \\
\hline & $66-70$ & $71-75$ & $76-80$ & $81-85$ & $86-90$ & $>90$ & \\
\hline \multicolumn{8}{|l|}{ Opname } \\
\hline Geheugenstoornissen & 6,6 & 8,8 & 8,4 & 7,8 & 10,3 & 9,0 & $<0.05$ \\
\hline Zwaarmoedigheid & 5,5 & 3,7 & 3,8 & 3,2 & 1,9 & 2,1 & $<0.01$ \\
\hline \multicolumn{8}{|l|}{ Ontslag } \\
\hline Zwaarmoedigheid & 3,9 & 2,6 & 3,4 & 2,0 & 1,3 & 1,6 & $<0.01$ \\
\hline
\end{tabular}

ANOVA; NB: Alle overige schalen tonen geen significante verschillen.

\subsubsection{GIP-score en geslacht (tabel 8.3.2.1)}

Over het geheel genomen wordt de GIP-score weinig of niet beinvloed door het geslacht. Een uitzondering vormen de subschalen voor decorumverlies en 
opstandig gedrag. Voor zover deze begrippen samenvallen met agressiviteit is deze bevinding consistent met de uitkomsten op de BOP-schaal.

Tabel 8.3.2.1 De gemiddelde scores per GIP-schaal voor vrouwen $(n=197)$ en mannen $(n=96)$ afzonderlijk, bij opname en ontslag.

\begin{tabular}{|c|c|c|c|c|c|c|c|}
\hline \multirow[b]{2}{*}{ GIP-schaal } & & \multicolumn{3}{|c|}{ Opname } & \multicolumn{3}{|l|}{ Ontslag } \\
\hline & & Vrouw & Man & p-waarde & Vrouw & Man & p-waarde \\
\hline Asociaal gedrag & $(0-24)$ & 9,7 & 10,1 & NS & 6,7 & 7,9 & NS \\
\hline Apathisch gedrag & $(0-18)$ & 7,4 & 7,4 & NS & 5,6 & 5,6 & NS \\
\hline Bewustzijnsstoornissen & $(0-21)$ & 3,8 & 4,3 & NS & 2,1 & 2,3 & NS \\
\hline Decorumverlies & $(0-15)$ & 4,6 & 5,7 & $<0.05$ & 3,3 & 4,2 & $<0.05$ \\
\hline Opstandig gedrag & $(0-15)$ & 2,0 & 3,0 & $<0.05$ & 1,2 & 2,7 & $<0.001$ \\
\hline Incoherent gedrag & $(0-15)$ & 2,6 & 2,8 & NS & 1,8 & 1,7 & NS \\
\hline Geheugenstoornissen & $(0-21)$ & 8,6 & 3,3 & NS & 7,2 & 6,6 & NS \\
\hline Desoriëntatie & $(0-15)$ & 4,2 & 4,1 & NS & 3,8 & 3,4 & NS \\
\hline Repetitief gedrag & $(0-15)$ & 1,7 & 1,8 & NS & 1,4 & 1,3 & NS \\
\hline Rusteloos gedrag & $(0-15)$ & 2,0 & 2,3 & NS & 1,9 & 2,0 & NS \\
\hline Achterdochtig gedrag & $(0-21)$ & 1,8 & 1,9 & NS & 1,3 & 1,4 & NS \\
\hline Zwaarmoedigheid & $(0-18)$ & 3,4 & 3,0 & NS & 2,4 & 2,3 & NS \\
\hline Afhankelijk gedrag & $(0-15)$ & 2,5 & 2,3 & NS & 1,9 & 2,0 & NS \\
\hline Angstig gedrag & $(0-18)$ & 0,5 & 0,4 & NS & 0,2 & 0,2 & NS \\
\hline
\end{tabular}

t-toets

\subsubsection{GIP-scores en mediane opnameduur (tabel 8.3.3.1)}

Bewustzijnsstoornissen zijn als enige significant van invloed op de opnameduur, zowel prospectief als retrospectief. De overige GIP-schalen hebben geen significante relatie met een langere of kortere opnameduur.

Tabel 8.3.3.1 De gemiddelde scores op de GIP-schalen uitgesplitst naar patiënten die $\leq$ mediane opnameduur $(n=153)$ en patiënten die $>$ mediane opnameduur $(n=140)$ zijn behandeld.

\begin{tabular}{|c|c|c|c|c|}
\hline \multirow[t]{2}{*}{ GIP-schaal } & \multicolumn{2}{|l|}{ Opname } & \multicolumn{2}{|l|}{ Ontslag } \\
\hline & $\leq$ mediaan $>$ & p-waarde & $\leq$ mediaan $>$ & p-waarde \\
\hline Bewegingsstoornis & $3,4 \quad 4,5$ & $<0.01$ & 1,7 & $<0.05$ \\
\hline
\end{tabular}

t-toets; NB: Overige GIP-schalen geen significante verschillen.

\subsubsection{GIP-scores en ADL-funktie (tabel 8.2.4.1)}

Wanneer de totale ADL-score gecorreleerd wordt aan de GIP-scores (tabel 8.3.4.1) dan blijkt dat voor 12 van de 14 schalen zowel bij opname als ontslag een significante correlatie te bestaan. Uitzondering vormen de schalen voor 
"opstandig gedrag" (5) en "zwaarmoedigheid" (12). De schalen die met name gericht zijn op het cognitief funktioneren $(1 \mathrm{t} / \mathrm{m} 8)$ met uitzondering van de genoemde schaal 5 hebben een relatief hoge correlatiecofficient. De overige schalen verdeeld over de kategorieën psychomotore stoornissen en emotionele stoornissen ( $9 \mathrm{t} / \mathrm{m} \mathrm{14}$ ) correleren veel zwakker en vaak negatief (m.n. emotionle stoornissen).

Tabel 8.3.4.1 De correlatie tussen de totale ADL-score en de scores op de GIP-schalen, bij opname en ontslag $(n=293)$.

\begin{tabular}{|c|c|c|c|c|c|}
\hline & & \multicolumn{2}{|c|}{ Opname } & \multicolumn{2}{|c|}{ Ontslag } \\
\hline & & $\mathbf{R}$ & p-waarde & $\mathbf{R}$ & p-waarde \\
\hline Asociaal Gedrag & $(0-24)$ & 0.53 & $<0.000$ & 0.40 & $<0.000$ \\
\hline Apatisch Gedrag & $(0-18)$ & 0.61 & $<0.000$ & 0.57 & $<0.000$ \\
\hline Bewustzijnsstoornis & $(0-21)$ & 0.52 & $<0.000$ & 0.53 & $<0.000$ \\
\hline Decorumverlies & $(0-15)$ & 0.63 & $<0.000$ & 0.64 & $<0.000$ \\
\hline Opstandig Gedrag & $(0-15)$ & 0.07 & NS & 0.06 & NS \\
\hline Incoherent Gedrag & $(0-15)$ & 0.37 & $<0.000$ & 0.37 & $<0.000$ \\
\hline Geheugenstoornis & $(0-21)$ & 0.48 & $<0.000$ & 0.50 & $<0.000$ \\
\hline Desoriëntatie & $(0-15)$ & 0.30 & $<0.000$ & 0.34 & $<0.000$ \\
\hline Repetitief Gedrag & $(0-15)$ & 0.35 & $<0.000$ & 0.47 & $<0.000$ \\
\hline Rusteloos Gedrag & $(0-15)$ & -0.17 & $<0.002$ & -0.12 & $<0.05$ \\
\hline Achterdochtig Gedrag & $(0-21)$ & -0.22 & $<0.000$ & -0.30 & $<0.000$ \\
\hline Zwaarmoedigheid & $(0-18)$ & -0.04 & NS & 0.09 & NS \\
\hline Afhankelijk Gedrag & $(0-15)$ & -0.11 & $<0.05$ & -0.12 & $<0.05$ \\
\hline Angstig Gedrag & $(0-18)$ & -0.04 & $<0.05$ & 0.14 & $<0.05$ \\
\hline
\end{tabular}

Pearson's correlatie coëfficient

Hieruit kan (voorzichtig) geconcludeerd worden dat stoornissen in het cognitief funktioneren zoals gemeten via de GIP-schalen samengaan met stoornissen in het ADL-funktioneren (en omgekeerd). Voor emotionele stoornissen, bijvoorbeeld depressiviteit wordt het tegenovergestelde waargenomen. De bevinding dat patiënten met depressiviteit zich wat betreft het funktioneren gunstig onderscheiden van de overige patiënten werd al eerder gedaan (hoofdstuk 6). Wanneer de gemiddelde uitkomsten van de scores op de GIP-schalen worden bepaald voor de gedichitomiseerde ADL-aktiviteit bij opname (tabel 8.3.4.2) is duidelijk dat de GIP-schalen hierdoor ook significant beïnvloed worden. Vanzelfsprekend zijn de uitkomsten konform de beschreven correlatie met de totale ADL-score. D.w.z. dat de eerste 8 schalen met uitzondering van schaal 5 significant hogere uitkomsten laten zien voor patiënten die wel ADL-afhankelijk zijn dan voor de patiënten die dat niet zijn. De laatste 6 schalen, voor zover significant verschillen aanwezig zijn, tonen het omgekeerde. 
Tabel 8.3.4.2 Uitkomsten GIP-scores in relatie tot de gedichotomiseerde ADL-variabelen bij opname $(0=$ onafhankelijk, $1=$ afhankelijk $)$.

\begin{tabular}{|c|c|c|c|c|c|c|c|c|c|c|c|}
\hline \multirow{3}{*}{$\begin{array}{l}\text { Opname } \\
\text { GIP }\end{array}$} & & \multicolumn{10}{|c|}{ ADL-funktie } \\
\hline & & \multicolumn{2}{|c|}{ wassen } & \multicolumn{2}{|c|}{ kleden } & \multicolumn{2}{|c|}{ toilet } & \multicolumn{2}{|c|}{ in/uit bed } & \multicolumn{2}{|c|}{ eten } \\
\hline & & 0 & 1 & 0 & 1 & 0 & 1 & 0 & 1 & 0 & 1 \\
\hline Asociaal Gedrag & $(0-24)$ & 7,3 & $11,7^{1}$ & 7,4 & $11,7^{1}$ & 6,7 & $10,7^{1}$ & 8,3 & $12,7^{1}$ & 7,9 & $12,5^{1}$ \\
\hline Apatisch Gedrag & $(0-18)$ & 4,8 & $9,2^{1}$ & 4,9 & $9,1^{1}$ & 4,5 & 8,2 & 6,0 & $10,0^{1}$ & 5,5 & $20,1^{1}$ \\
\hline Bewustzijnsstoornis & $(0-21)$ & 2,0 & $5,3^{1}$ & 1,9 & $5,3^{1}$ & 1,6 & $4,6^{1}$ & 2,7 & $6,2^{1}$ & 2,4 & $6,1^{1}$ \\
\hline Decorumverlies & $(0-15)$ & 2,4 & $6,7^{1}$ & 2,5 & $6,6^{1}$ & 1,9 & $5,8^{1}$ & 3,8 & $7,1^{1}$ & 3,2 & $7,4^{1}$ \\
\hline Opstandig Gedrag & $(0-15)$ & 2,1 & 2,5 & 2,1 & 2,5 & 1,9 & 2,5 & 2,3 & 2,5 & 2,1 & 2,6 \\
\hline Incoherent Gedrag & $(0-15)$ & 1,4 & $3,6^{1}$ & 1,5 & $3,5^{1}$ & 1,6 & $3,0^{1}$ & 2,1 & $3,7^{1}$ & 1,7 & $3,9^{1}$ \\
\hline Geheugenstoornissen & $(0-21)$ & 5,8 & $10,5^{1}$ & 6,0 & $10,3^{1}$ & 5,4 & $9,4^{1}$ & 7,5 & $10,4^{1}$ & 6,4 & $11,5^{1}$ \\
\hline Desoriēntatie & $(0-15)$ & 3,0 & $4,9^{1}$ & 3,1 & $4,9^{1}$ & 2,8 & $4,5^{3}$ & 3,8 & $4,8^{4}$ & 3,0 & $5,8^{1}$ \\
\hline Repetitief Gedrag & $(0-15)$ & 0,9 & $2,4^{1}$ & 0,9 & $2,4^{1}$ & 0,8 & $2,0^{1}$ & 1,1 & $2,9^{1}$ & 0,9 & $2,9^{1}$ \\
\hline Rusteloos Gedrag & $(0-15)$ & 2,6 & $1,7^{2}$ & 2,5 & $1,8^{4}$ & 3,0 & $1,8^{2}$ & 2,4 & $1,6^{4}$ & 2,3 & 1,8 \\
\hline Achterdochtig Gedrag & $(0-21)$ & 2,5 & $1,4^{2}$ & 2,5 & $1,4^{3}$ & 2,8 & $1,6^{4}$ & 2,2 & $1,1^{2}$ & 2,5 & $1,0^{4}$ \\
\hline Zwaarmoedigheid & $(0-18)$ & 3,4 & 3,1 & 3,4 & 3,2 & 3,4 & 3,2 & 3,0 & 3,6 & 3,6 & $2,7^{2}$ \\
\hline Afhankelijk Gedrag & $(0-15)$ & 2,9 & $2,1^{4}$ & 3,0 & $2,1^{2}$ & 2,7 & 2,4 & 2,4 & 3,6 & 2,8 & $2,0^{2}$ \\
\hline Angstig Gedrag & $(0-18)$ & 0,5 & 0,4 & 0,5 & 0,4 & 0,7 & 0,4 & 0,5 & 0,4 & 0,4 & 0,4 \\
\hline
\end{tabular}

${ }^{1} p=0.000,{ }^{2} p \leq 0.01,{ }^{3} p \leq 0.001,{ }^{4} p \leq 0.05$

\subsubsection{De GIP-scores en het Geriatrisch Complex}

Het Geriatrisch Complex bevat naast meer somatisch georiënteerde elementen ook een tweetal elementen te weten cognitieve stoornissen en dementiesyndroom, die, zo kan verondersteld worden, effekt mochten hebben c.q. teruggevonden moeten worden in de uitkomsten van de GIP-scores. De relatief korte opnameduur van veel patiënten in het ziekenhuis en de impact van de therapeutische interventies gedurende opname zouden ertoe kunnen leiden dat dit effekt bij opname minder goed wordt teruggevonden (korte observatietijd) of bij ontslag minder uitgesproken is (verbeterd funktioneren). Uit tabel 8.3.5.1 en 8.3.5.2 blijkt dat slechts een beperkt aantal GIP-schalen significante verschillen laten zien tussen de patiënten met elementen van het Geriatrisch Complex $(n=188)$ en de patiënten zonder deze elementen $(n=105)$.

Bij opname bestaan significante verschillen voor uitkomsten van de groepsgemiddelden op de schalen "inconherent gedrag, geheugenstoornissen, desoriëntatie, zwaarmoedigheid, afhankelijk gedrag en inaktiviteit". Het meest uitgesproken zijn de verschillen in de schalen die betrekking hebben op het cognitief funktioneren. Deze blijven ook significante verschillen opleveren bij ontslag, terwijl de uitkomsten op de schalen die meer betrekking hebben op emotionele stoornissen bij ontslag niet langer verschillend zijn voor beide groepen. Ook hier kan de behandelbaarheid van dergelijke problematiek de verklaring zijn. Hierbij moet wel gewezen worden op de zowel bij opname als 
Tabel 8.3.5.1 De gemiddelde scores op de GIP-schalen van patiënten met elementen uit het Geriatrisch Complex $(n=188)$ en patiënten zonder dergelijke elementen $(n=105)$ bij opname.

\begin{tabular}{|c|c|c|c|c|}
\hline GIP-schaal & & $\begin{array}{l}\text { Patiënt zonder } \\
\text { Geriatrisch } \\
\text { Complex }\end{array}$ & $\begin{array}{l}\text { Patiënt met } \\
\text { Geriatrisch } \\
\text { Complex }\end{array}$ & p-waarde \\
\hline Asociaal Gedrag & $(0-24)$ & 9,2 & 9,4 & NS \\
\hline Apatisch Gedrag & $(0-18)$ & 6,5 & 7,0 & NS \\
\hline Bewustzijnsstoornis & $(0-21)$ & 3,5 & 3,4 & NS \\
\hline Decorumverlies & $(0-15)$ & 4,0 & 5,1 & $<0.05$ \\
\hline Opstandig Gedrag & $(0-15)$ & 1,8 & 2,6 & NS \\
\hline Incoherent Gedrag & $(0-15)$ & 2,0 & 3,0 & $<0.05$ \\
\hline Geheugenstoornissen & $(0-21)$ & 6,0 & 9,6 & $<0.000$ \\
\hline Desoriëntatie & $(0-15)$ & 2,4 & 5,1 & $<0.000$ \\
\hline Repetitief Gedrag & $(0-15)$ & 1,2 & 1,9 & NS \\
\hline Rusteloos Gedrag & $(0-15)$ & 2,1 & 2,4 & NS \\
\hline Achterdochtig Gedrag & $(0-21)$ & 2,2 & 1,6 & NS \\
\hline Zwaarmoedigheid & $(0-18)$ & 4,2 & 2,7 & $<0.05$ \\
\hline Afhankelijk Gedrag & $(0-15)$ & 3,6 & 2,0 & $<0.000$ \\
\hline Angstig Gedrag & $(0-18)$ & 0,8 & 0,2 & $<0.01$ \\
\hline
\end{tabular}

ANOVA

Tabel 8.3.5.2 De gemiddelde scores op de GIP-schalen van patiënten met elementen uit het Geriatrisch Complex $(n=188)$ en patiënten zonder dergelijke elennenten $(n=105)$ bij ontslag.

\begin{tabular}{lllll} 
GIP-schaal & & $\begin{array}{l}\text { Patiënt zonder } \\
\text { Geriatrisch } \\
\text { Complex }\end{array}$ & $\begin{array}{l}\text { Patiënt met } \\
\text { Geriatrisch } \\
\text { Complex }\end{array}$ & p-waarde \\
\hline Asociaal Gedrag & $(0-24)$ & 7,0 & 7,2 & NS \\
Apatisch Gedrag & $(0-18)$ & 5,6 & 5,6 & NS \\
Bewustzijnsstoornis & $(0-21)$ & 2,1 & 2,0 & NS \\
Decorumverlies & $(0-15)$ & 2,8 & 3,8 & NS \\
Opstandig Gedrag & $(0-15)$ & 1,4 & 1,9 & NS \\
Incoherent Gedrag & $(0-15)$ & 0,9 & 2,0 & $<0.05$ \\
Geheugenstoornissen & $(0-21)$ & 3,9 & 8,4 & $<0.000$ \\
Desoriëntatie & $(0-15)$ & 1,2 & 4,4 & $<0.000$ \\
Repetitief Gedrag & $(0-15)$ & 0,8 & 1,4 & NS \\
Rusteloos Gedrag & $(0-15)$ & 1,4 & 2,1 & NS \\
Achterdochtig Gedrag & $(0-21)$ & 1,2 & 1,1 & NS \\
Zwaarmoedigheid & $(0-18)$ & 2,7 & 2,2 & NS \\
Afhankelijk Gedrag & $(0-15)$ & 2,2 & 1,5 & NS \\
Angstig Gedrag & $(0-18)$ & 0,3 & 0,2 & NS \\
\hline
\end{tabular}

ANOVA 
ontslag relatief lage scores op deze schalen. Voorts is vermeldingswaardig dat, waar bij opname patiënten zonder elementen van het Geriatrisch Complex nog relatief hoog scoren op een aantal meer cognitief georiënteerde schalen, deze scores bij ontslag (uiteraard) zeer laag zijn. In hoeverre bijvoorbeeld delirante beelden hierbij een rol spelen is onduidelijk, zij het dat geen verschil gevonden wordt tussen beide groepen op het niveau van bewustzijnsstoornissen (gemeten in de $2 e$ en laatste: week van opname).

\subsubsection{De GIP-scores en het dementiesyndroom}

Evenals voor de BOP-scores is nagegaan in hoeverre de patiënten met een dementiesyndroom (n-98) verschillen van patiënten zonder cognitieve stoornissen en/of depressieve kenmerken $(n=98)$. De verwachting hierbij is dat eerstgenoemde patiënten, gelet op de voor gedragsstoornissen meer gedetailleerde GIP-schalen hierbij duidelijker onderscheid laten zien dan bij de BOPschalen. Uit tabel 8.3.6.1 en 8.3.6.2 blijkt dat dit zeker niet steeds het geval is. Waar de BOP-schalen vrijwel steeds (uitzondering: de score op lichamelijke invaliditeit bij opname) significant verschillen laten zien, zijn er zowel op het vlak van de cognitieve stoornissen als op het vlak van de emotionele stoornissen een aantal schalen die geen verschillen laten zien tussen patiënten met en zonder dementie.

Tabel 8.3.6.1 De GIP-scores bij opname van patiënten met een dementie-syndroom $(n=98)$ in vergelijking met de andere onderzochte patiënten, gecorrigeerd voor overige cognitieve stoornissen en depressie.

\begin{tabular}{|c|c|c|c|c|}
\hline GIP-schaal & & $\begin{array}{l}\text { Patiënt met } \\
\text { dementie }\end{array}$ & $\begin{array}{l}\text { Patiënt zonder } \\
\text { dementie }\end{array}$ & p-waarde \\
\hline Asociaal Gedrag & $(0-24)$ & 10,4 & 8,2 & $<0.01$ \\
\hline Apathisch Gedrag & $(0-18)$ & 7,3 & 5,9 & $<0.001$ \\
\hline Bewijstzijnsstoornis & $(0-21)$ & 4,0 & 3,0 & NS \\
\hline Decorumverlies & $(0-15)$ & 5,6 & 3,7 & $<0.001$ \\
\hline Opstandig Gedrag & $(0-15)$ & 3,0 & 1,8 & $<0.05$ \\
\hline Incoherent Gedrag & $(0-15)$ & 3,6 & 1,7 & $<0.0000$ \\
\hline Geheugenstoornissen & $(0-21)$ & 11,7 & 5,3 & $<0.0000$ \\
\hline Desoriëntatie & $(0-15)$ & 6,5 & 2,1 & $<0.0000$ \\
\hline Repetitief Gedrag & $(0-15)$ & 2,4 & 0,9 & $<0.001$ \\
\hline Rusteloos Gedrag & $(0-15)$ & 2,9 & 1,8 & $<0.05$ \\
\hline Achterdochtig Gedrag & $(0-21)$ & 1,2 & 2,0 & NS \\
\hline Zwaarmoedigheid & $(0-18)$ & 1,9 & 4,2 & $<0.0000$ \\
\hline Afhankelijk Gedrag & $(0-15)$ & 1,8 & 3,1 & $<0.01$ \\
\hline Angstig Gedrag & $(0-18)$ & 0,3 & 0,5 & NS \\
\hline
\end{tabular}

ANOVA 
Tabel 8.3.6.2 De GIP-scores bij ontslag van patiënten met een dementie-syndroom ( $\mathrm{n}=98$ ) in vergelijking met de andere onderzochte patiënten, gecorrigeerd voor overige cognitieve stoornissen en depressie.

\begin{tabular}{|c|c|c|c|c|}
\hline GIP-schaal & & $\begin{array}{l}\text { Patiënt met } \\
\text { dementie }\end{array}$ & $\begin{array}{l}\text { Patiënt zonder } \\
\text { dementie }\end{array}$ & p-waarde \\
\hline Asociaal Gedrag & $(0-24)$ & 8,1 & 6,7 & NS \\
\hline Apathisch Gedrag & $(0-18)$ & 6,5 & 5,0 & $<0.01$ \\
\hline Bewustzijnsstoornis & $(0-21)$ & 2,5 & 2,0 & NS \\
\hline Decorumverlies & $(0-15)$ & 4,4 & 2,8 & $<0.01$ \\
\hline Opstandig Gedrag & $(0-15)$ & 2,1 & 1,5 & NS \\
\hline Incoherent Gedirag & $(0-15)$ & 2,7 & 0,7 & $<0.0000$ \\
\hline Geheugenstoornissen & $(0-21)$ & 10,7 & 3,5 & $<0.0000$ \\
\hline Desoriëntatie & $(0-15)$ & 6,0 & 1,3 & $<0.0000$ \\
\hline Repetitief Gedrag & $(0-15)$ & 2,0 & 0,8 & $<0.01$ \\
\hline Rusteloos Gedrag & $(0-15)$ & 2,7 & 1,2 & $=0.001$ \\
\hline Achterdochtig Gedrag & $(0-21)$ & 0,8 & 1,4 & NS \\
\hline Zwaarmoedigheid & $(0-18)$ & 1,5 & 3,0 & $<0.01$ \\
\hline Afhankelijk Gedrag & $(0-15)$ & 1,3 & 2,3 & $<0.01$ \\
\hline Angstig Gedrag & $(0-18)$ & 0,3 & 0,2 & NS \\
\hline
\end{tabular}

ANOVA

Bewustzijnsstoornissen (schaal 3) worden zowel bij opname als bij ontslag in beide groepen evenzeer aangetroffen. Dit is waarschijnlijk verklaarbaar uit het feit dat dergelijke stoornissen veelal zijn terug te voeren op comorbiditeit, waarbij de aan- of afwezigheid van dementie geen rol van betekenis speelt. Voor zover dergelijke stoornissen iatrogeen geïnduceerd kunnen worden door bijvoorbeeld psychofarmaca is het effekt hiervan kennelijk niet verschillend voor beide groepen. Het ontbreken van verschillen in asociaal gedrag (schaal 1) en opstandig gedrag (schaal 5) bij ontslag kan mogelijk verklaard worden door dergelijk gebruik van psychofarmaca, of een gevolg zijn van indolentie ten gevolge van de effekten van ziekenhuisopname in het algemeen. Het ontbreken van verschillen in achterdochtig gedrag (schaal 11) en angstig gedrag (schaal 14) heeft mogelijk te maken met de beperkingen die de relatief korte observatietijd in het ziekenhuis met zich meebrengt. Het feit dat niet-demente patiënten gemiddeld hoger scoren op de laatste vier schalen is indikatief voor het feit dat bij patiënten met dementie meer scrupuleus geëvalueerd en benoemd wordt in hoeverre depressie een rol speelt in hun funktioneren. In vergelijking met de uitkomsten van de GIP-scores, zoals beschreven door Verstraten e.a. (1987) bij psychogeriatrische verpleeghuisbewoners en psychogeriatrische dagbehandelingsbezoekers zijn de uitkomsten afwisselend hoger en lager dan in deze beide populaties. Dit is logisch omdat de onderzochte patiëntengroep veel gemêleerder is wat betreft de samenstelling en slechts ten dele bestaat uit personen die thuishoren c.q. terechtkomen in één van beide genoemde groepen. De aanwezigheid van significante verschil- 
len op 11 van de 14 schalen bij opname en 9 van de 14 schalen bij ontslag duidt erop dat over het algemeen de schalen binnen het bestek van de ziekenhuisopname wel bruikbaar zijn voor geriatrische patiënten.

In hoeverre de GIP-schalen bruikbaar zijn in de (psycho)diagnostiek is de vraag. Voor het grootste deel bestaat een aanzienlijke overlap tussen wel en niet demente patiënten. Alleen de schalen "geheugenstoornissen" en "desoriëntatie" tonen een zodanig verschil dat ze een hulpmiddel kunnen vormen in dit verband. Het funktioneren op dit vlak wordt echter ook door tal van andere (eenvoudige) psychodiagnostische tests mogelijk gemaakt, zoals bijvoorbeeld de Mini Mental State Examination.

\subsubsection{GIP-scores en ontslagrichting (tabel 8.3.7.1)}

Alhoewel op het eerste gezicht lijkt dat een deel van de GIP-schalen (bij opname 7 schalen en bij ontslag 4 schalen) wellicht bruikbaar zijn voor de ontslagrichting mede te bepalen is dit bij nadere beschouwing niet waarschijnlijk. De verschillen zijn statistisch voldoende significant maar in absolute zin zeer gering en in kombinatie met een relatief grote overlap verhindert dit praktische toepassing. Alhoewel de oorspronkelijke ontwerpers aangeven dat de GIP-schalen ook voor beslissingen ten aanzien van het ontslagbeleid bruikbaar zijn blijkt dit in de onderzochte populatie, onder de specifieke omstandigheid van ziekenhuisopname niet. Het is mogelijk dat bij verdere verfijning van de gegevens betreffende de ontslagrichting, zoals wel of niet een psychogeriatrisch verpleeghuis, wel of niet aanvullende zorg in de zin van dagbehandeling of begeleiding SPGD, etc. de bruikbaarheid van de GIP-schalen groter zou blijken, ook in de onderhavige situaties. Analyse van een specifieke subgroep, te weten patiënten met dementie suggereert dit wel enigszins, wanneer patiënten die naar een psychogeriatrisch verpleeghuis zijn ontslagen worden vergeleken met de patiënten die naar elders zijn gegaan. Deze uitkomsten zijn echter weinig betrouwbaar omdat een deel van deze specifieke patiëntenkategorie in verband met wachtlijstproblematiek - al dan niet tijdelijk - in een andere voorziening is geplaatst, zoals een kleinschalig bejaardenhuis.

Overigens is - evenals bij de BOP-score - de correlatie tussen de GIP-scores bij opname en ontslag relatief hoog. Dit verhoogt de bruikbaarheid in de gevonden populatie echter niet gelet op het voorafgaande.

De voor de meerderheid van de schalen bestaande significante relatie met het zelfzorgvermogen geeft aan dat deze meer specifieke psychogeriatrische schalen beter inzicht geven in de betekenis van psychische problematiek voor het verzorgingsniveau dan de 'psychische schalen' in de BOP-score. 
Tabel 8.3.7.1 De betekenis van de GIP-score bij opname en ontslag voor de ontslagrichting $(n=293)$. Onderscheiden worden: zelfstandige woonsituatie $(Z W)$, verzorgingstehuis $(\mathrm{VZH})$ en verplaaghuis (VPH).

Opname

\begin{tabular}{lccccc}
\hline GIP-schaal & & ZW & VZH & VPH & p-waarde \\
\hline Asociaal Gedrag & $(0-24)$ & 8,0 & 10,0 & 10,9 & $<0.001$ \\
Apatisch Gedrag & $(0-18)$ & 5,9 & 7,6 & 8,6 & $=0.0001$ \\
Bewustzijnsstoornis & $(0-21)$ & 2,8 & 3,6 & 5,1 & $<0.001$ \\
Decorumverlies & $(0-15)$ & 4,0 & 4,7 & 5,9 & $<0.01$ \\
Opstandig Gedrag & $(0-15)$ & 2,2 & 2,0 & 2,4 & NS \\
Incoherent Gedrag & $(0-15)$ & 2,2 & 2,4 & 3,2 & NS \\
Geheugenstoornissen & $(0-21)$ & 7,0 & 9,6 & 8,9 & $<0.01$ \\
Desoriëntatie & $(0-15)$ & 3,3 & 5,0 & 4,6 & $<0.01$ \\
Repetitief Gedrag & $(0-15)$ & 1,2 & 1,7 & 2,3 & $=0.05$ \\
Rusteloos Gedrag & $(0-15)$ & 2,4 & 2,1 & 1,9 & NS \\
Achterdochtig Gedrag & $(0-21)$ & 2,3 & 1,7 & 1,2 & NS \\
Zwarmoedigheid & $(0-18)$ & 3,3 & 3,5 & 3,1 & NS \\
Afhankelijk Gedrag & $(0-15)$ & 2,4 & 2,6 & 2,6 & NS \\
Angstig Gedrag & $(0-18)$ & 0,3 & 0,5 & 0,6 & NS \\
\hline
\end{tabular}

Ontslag

\begin{tabular}{llllll}
\hline GIP-schaal & & ZW & VZH & VPH & p-waarde \\
\hline Asociaal Gedrag & $(0-24)$ & 6,4 & 7,3 & 8,0 & NS \\
Apatisch Gedrag & $(0-18)$ & 4,5 & 6,2 & 6,7 & $<0.001$ \\
Bewustzijnsstoornis & $(0-21)$ & 1,5 & 2,4 & 2,8 & $<0.05$ \\
Decorumverlies & $(0-15)$ & 3,1 & 3,7 & 4,3 & NS \\
Opstandig Gedrag & $(0-15)$ & 1,6 & 1,8 & 1,8 & NS \\
Incoherent Gedrag & $(0-15)$ & 1,5 & 2,0 & 1,9 & NS \\
Geheugenstoornissen & $(0-21)$ & 5,7 & 8,6 & 7,6 & $=0.001$ \\
Desoriëntatie & $(0-15)$ & 2,8 & 4,6 & 4,3 & $<0.01$ \\
Repetitief Gedrag & $(0-15)$ & 1,0 & 1,5 & 1,7 & NS \\
Rusteloos Gedrag & $(0-15)$ & 2,1 & 2,0 & 1,7 & NS \\
Achterdochtig Gedrag & $(0-21)$ & 1,6 & 1,2 & 0,9 & NS \\
Zwaarmoedigheid & $(0-18)$ & 2,2 & 2,4 & 2,7 & NS \\
Afhankelijk Gedrag & $(0-15)$ & 1,8 & 1,8 & 2,0 & NS \\
Angstig Gedrag & $(0-18)$ & 0,1 & 0,4 & 0,4 & NS
\end{tabular}

ANOVA

\subsubsection{GIP-scores-resumé}

De GIP-schalen worden weinig of niet beinvloed door leeftijd, geslacht en opnameduur. Ondanks dat het in principe om het psychisch funktioneren handelt, blijkt de relatie met het zelfzorgvermogen duidelijk aanwezig, waarbij een zekere hierarchie aanwezig lijkt. Patiënten met een dementiesyndroom 
worden door de schalen "geheugenstoornis" en "desoriëntatie" duidelijk onderscheiden van de overige geriatrische patiënten, maar of hieraan behoefte bestaat is de vraag. Voor het bepalen van de ontslagrichting, zoals in de inleiding reeds gezegd een belangrijk onderdeel van de aktiviteit rondom geriatrische patiënten in een ziekenhuis bieden de GIP-schalen weinig houvast. Op grond van bovenstaande overwegingen wordt gekonkludeerd dat de GIP-schalen weliswaar een verfijning vormen voor de classificatie van observationele gegevens m.b.t. gedragsstoornissen, maar dat de meerwaarde ten opzichte van de BOP-schaal en (nog basaler) de scoring van het zelfzorgvermogen m.b.t. ADL-funkties bij de onderzochte patiënten zeer gering is geweest. 


\section{Bijlage 8-1}

\begin{tabular}{lll}
\hline BOP-schalen & range \\
\hline 1 & hulpbehoevendheid & $0-46$ \\
2 & agressiviteit & $0-10$ \\
3 & lichamelijke invaliditeit & $0-6$ \\
4 & depressief gedrag & $0-6$ \\
5 & psychische invaliditeit & $0-8$ \\
6 & inaktiviteit & $0-14$ \\
\hline
\end{tabular}

GIP-schalen

\begin{tabular}{lll}
\hline 1 & asociaal gedrag & $0-24$ \\
2 & apathisch gedrag & $0-18$ \\
3 & bewustzijnsstoornissen & $0-21$ \\
4 & decorumverlies & $0-15$ \\
5 & opstandig gedrag & $0-15$ \\
6 & incoherent gedrag & $0-15$ \\
7 & geheugenstoornissen & $0-21$ \\
8 & desoriëntatie & $0-15$ \\
9 & repetitief gedrag & $0-15$ \\
10 & rusteloos gedrag & $0-15$ \\
11 & achterdochtig gedrag & $0-21$
\end{tabular}




\section{Samenvatting en konklusies}

Er wordt veel gesproken over vergrijzing en de gevolgen die dit heeft voor de gezondheidszorg. Niet zelden wordt daarbij weinig onderscheid gemaakt tussen oudere patiënten en geriatrische patiënten. In een aantal gevallen worden beide begrippen zelfs als synoniemen gebruikt. Dit heeft verstrekkende gevolgen, omdat het aantal "ouderen" of "bejaarde patiënten" vele malen groter is dan het aantal geriatrische patiënten. Daarbij komt dat een wezenlijk onderscheid bestaat in zorgbehoefte, diagnostische en therapeutische mogelijkheden en funktioneringsniveau. Wanneer de problematiek van (psycho-) geriatrische patiënten wordt geëxtrapoleerd naar de voorzieningenbehoefte van de totale bejaarde bevolking - nu en in de toekomst - ontstaat een sterk vertekend beeld. Deze vertekening is ook waarneembaar in veel handboeken en monografiën, waarin geriatrische problematiek wordt behandeld, maar ouderenzorg wordt beschreven. De verklaring hiervoor is dat de gehanteerde definities van wat een geriatrische patiënt is veel ruimte laten voor interpretatie. Toch wil dit niet zonder meer zeggen dat op het vlak van de praktische uitvoering van de gezondheidszorg geen onderscheid gemaakt wordt tussen oudere patiënten en geriatrische patiënten. Verwijzers in de le en $2 e$ lijn, huisartsen en medisch specialisten lijken toch selektiecriteria te hanteren bij de besluitvorming een patiënt naar een "gewone zorgvoorziening" te verwijzen danwel te opteren voor een voorziening met het predikaat geriatrie.

In het Academisch Ziekenhuis Maastricht bestaat sedert 1987 een behandelteam dat werkt volgens de principes van "Flankerend Geriatrisch Beleid". Deze voorziening is erop gericht oudere patiënten, waarvan verwijzers en/of behandelaars menen dat zij behoren tot de kategorie geriatrische patiënten, naast de conventionele medische behandeling waarvoor zij opgenomen worden in het ziekenhuis een komplementaire behandeling te geven die gericht is op de specifiek geriatrische problematiek die bij deze patiënten wordt vastgesteld. Het gaat hierbij om een pakket van maatregelen, met name gericht op funktionele problematiek voortvloeiend uit veel voorkomende geriatrische problemen zoals multiple pathologie, overmedikatie, stoornissen in het zelfzorgvermogen, psychosociale problemen, mobiliteitsstoornissen, kommunikatiestoornissen, behoefte aan chronische zorgverlening, incontinentie en gedragsproblematiek. Het team dat bestaat uit een internist, een konsultatieve psychiater, een revalidatiearts, fysiotherapeuten, maatschappe- 
lijk werkenden en medewerkers van de aktiviteitentherapie probeert in samenwerking met de overige betrokken medisch specialisten, verpleegkundigen en andere bij de direkte patiëntenzorg betrokkenen, gestalte te geven aan de geriatrische interventie door systematisch aandacht te schenken aan aktiverende en (re-)socialiserende maatregelen, bewaking van de medikatie, het in een funktioneel perspektief plaatsen van de diagnostiek en behandleling en het bewaken van een opname- en ontslagbeleid gericht op kontinuilteit van zorg.

In het hier gepresenteerde onderzoek wordt - binnen het kader van het Flankerend Geriatrisch Beleid - verslag gedaan van de bevindingen bij de onderzochte geriatrische patiënten gedurende hun verblijf in het ziekenhuis. Het onderzoek heeft zich uitgestrekt over een periode van 27 maanden, waarin een systematische gegevensregistratie bij opname en ontslag heeft plaatsgevonden van in totaal 1122 opnames.

In de inleiding wordt een korte beschouwing gegeven over de problematiek rondom de definitie van de geriatrische patiënt en het werkterrein van de klinische geriatrie, waarna aangegeven wordt wat de doelstellingen van het onderzoek zijn geweest, te weten

- een nadere precisering van het onderscheid tussen "gewone ouderen" en geriatrische patiënten

- een beschrijving van de medische en funktioneringskenmerken van geriatrische patiënten bij opname in het ziekenhuis

- analyse van de ontwikkelingen in het funktioneren gedurende klinische behandeling van geriatrische patiënten

- het bepalen van de betekenis van geriatrische problematiek bij het risiko op overlijden

- het vaststellen van de mogelijkheden die bepaalde instrumenten voor beoordeling en classificatie van geriatrische problematiek bieden in het perspektief van de uitkomsten van de zorgverlening.

Hoofdstuk 1 geeft een inleiding op de vergrijzingsproblematiek. Na presentatie van de demografische ontwikkelingen en de hieraan verbonden konsequenties wordt ingegaan op de gezondheidszorg van ouderen, de betekenis van komplexiteit van ziekte voor de zorgvraag en de behoefte aan gedifferentieerde zorg voor geriatrische patiënten. Er wordt onderscheid gemaakt tussen:

1 ouderen met enkelvoudige, veelal acute intercurrente aandoeningen;

2 ouderen met meer complexe, doorgaans chronische medische problematiek, waarbij desondanks een stabiele situatie bereikt kan worden

3 oudere geriatrische patiënten bij wie een wankel evenwicht en grote hulpbehoevendheid bestaat ten gevolge van multiple pathologie, voortkomend uit een kombinatie van lichamelijke, psychische en sociale problemen. 
Vervolgens wordt de historie van de geriatrische zorg in internationaal perspektief beschreven. Verder wordt ingegaan op het rendement van een zelfstandige geriatrische afdeling, de geschiedenis van de klinisch-geriatrische zorg in Nederland en de belangrijkste voor- en nadelen van een zgn. GAAZ (Geriatrische Afdeling Algemeen Ziekenhuis) zoals die door de auteur worden gezien. Hierbij wordt ook aangegeven wat de gevolgen zijn voor het specialisme klinische geriatrie in geval van volledige implementatie van het huidige gezondheidszorgbeleid bij alle geriatrische patiënten in Nederland. De genoemde voor- en nadelen zijn niet beschreven als polariteiten, maar meer als van elkaar verschillende overwegingen van belang bij het denken over en het uitvoeren van klinisch geriatrische zorg al dan niet binnen de contouren van een zelfstandige geriatrische afdeling. Het ontbreken van doorslaggevende pro's en kontra's laat de lezer in zekere zin de vrijheid hieruit zijn of haar eigen konklusies te trekken.

In hoofdstuk 2 wordt nader ingegaan op de basisfilosofie en de uitgangspunten van het Flankerend Geriatrisch Beleid. Beschreven wordt de wijze van organisatie en de instroom van patiënten. Hierna wordt ingegaan op de begrippen reaktivatie, resocialisatie, demedikatie, funktionele heroriëntatie en kontinuïteit van zorg als hoofdbestanddelen van de behandelingsstrategie in het kader van het Flankerend Geriatrisch Beleid. Bij reaktivatie komt aan de orde het belang van specifieke aandacht voor ADL-aktiviteit, mobiliteit en incontinentie in relatie tot de medische en paramedische inspanningen rondom een geriatrische patiënt. Resocialisatie gaat in op de aktiviteit bedoeld om het psychosociaal funktioneren van de al dan niet cognitief gestoorde patiënt gedurende ziekenhuisopname zoveel mogelijk te optimaliseren. De motivatie van stringente bewaking van de medikatie worden uiteengezet onder "demedikatie". Onder Funktionele Heroriëntatie wordt ingegaan op de konsequenties die verbonden worden aan beperkte levensverwachting en veranderde cure/care verhouding en het belang van vroegtijdige besluitvorming over de beperkingen die gesteld moeten worden aan het medisch handelen. Kontinuiiteit van zorg tenslotte is de noemer van die aktiviteit die het transmurale karakter van de geriatrie benadrukken.

Hoofdstuk 3 geeft allereerst een beschrijving van de achtergrond en instroom van de onderzoekspopulatie. Dit wordt in verband gebracht met het bereik van het Flankerend Geriatrisch Beleid, waarbij gekonkludeerd wordt dat dit tenminste $50 \%$ van de geriatrische problematiek in het verzorgingsgebied betreft.

Ingegaan wordt op de nauwe relatie die - mede door de samenstelling van het behandelteam en de aard van de aangetroffen pathologie - bestaat tussen het Flankerend Geriatrisch Beleid en het specialisme interne geneeskunde.

Vanuit eerder genoemde optiek wordt ingegaan op het belang onderscheid te maken tussen "gewone ouderen" en geriatrische patiënten in het ziekenhuis 
en worden de vraagstellingen en werkhypothese nader uitgewerkt. Dit wordt in verband gebracht met het operationele effekt dat het Flankerend Geriatrisch Beleid heeft. Vervolgens wordt een beschrijving gegeven van de geregistreerde parameters als leiclraad voor de interpretatie van de verder gepresenteerde onderzoeksgegevens.

In hoofdstuk 4 wordt het onderzoek beschreven naar het onderscheid tussen "gewone ouderen" en geriatrische patiënten. Hierbij blijkt dat geriatrische patiënten voor opname in sterkere mate zorgafhankelijk zijn en vaker heropgenomen worden in het ziekenhuis. Frequenter bestaat naast een somatische ook een psychische of sociale indikatie voor opname. De behoefte aan konsulenten vanuit de disciplines neurologie, psychiatrie, urologie en revalidatiegeneeskunde is hoger. Naast een ruim twee maal zo lange ligduur blijkt het percentage dat overlijdt gedurende ziekenhuisopname ruim 4 maal zo hoog. Voorts worden significante verschillen gevonden wat betreft ADL-funktioneren, mobiliteit en incontinentie, alle ten nadele van de geriatrische patiënt. Ook wat betreft de ontslagrichting is het verschil evident, met name de aantallen geriatrische patiënten die ontslagen worden naar een (veela! kleinschalig) verzorgingstehuis en een psychogeriatrische verpleegkliniekafdeling. De gevonden verschillen vormen als het ware de motivatie voor de verdere bestanddelen van het onderzoek, waarbij nader ingegegaan wordt op de genoemde elementen. Gekonkludeerd wordt dat de verschillen dermate zijn dat een "gespecialiseerde" geriatrische benadering gerechtvaardigd is.

In hoofdstuk 5 wordt aan de hand van de onderzochte parameters een korte beschrijving gegeven van het funktioneren bij opname, waarbij blijkt dat vrijwel alle onderzochte patiënten stoornissen hebben in het ADL-funktioneren en/of de mobiliteit en/of urine-incontinentie. Aan de hand van de gekonstateerde diagnoses en problemen worden 28 ziektebeelden geïdentificeerd die bij tenminste $5 \%$ van de patiënten voorkomen en gezamenlijk bijna $60 \%$ vormen van de totale diagnoselast. Op zich lijken deze ziektebeelden slechts weinig onderlinge samenhang te vertonen. Met behulp van clusteranalyse volgens Jaccard wordt hierna een vijftal diagneses/problemen geïdentificeerd die in zekere zin karakteristiek genoemd kunnen worden voor de onderzoekspopulatie: tweederde van de patiënten heeft éen of meer kenmerken van dit zgn. Geriatrisch Complex. De onderscheiden elementen zijn: cognitieve stoornissen, verzorgingsproblemtiek, acute incontinentie, acute immobilisatie en het dementiesyndroom. Dit complex blijkt op het niveau van funktioneren bij opname van significante invloed. Aandacht voor de onderdelen van dit complex en de invloed die hiervan uitgaat op het funktioneren wordt beschouwd als het centrale thema in de geriatrische zorgverlening.

Hoofdstuk 6 beschrijft het beloop van de funktioneringsparameters van de geriatrische patiënten gedurende ziekenhuisopname. Er worden op groepsni- 
veau significante verbeteringen gevonden in het funktioneren bij ontslag ten opzichte van opname. Deze zijn niet gerelateerd aan leeftijd of geslacht. De invloed van de 28 meest voorkomende diagnoses op de veranderingen in het ADL-funktioneren, de mobiliteit en/of de urine-incontinentie zijn zeer beperkt. Het Geriatrisch Complex daarentegen is sterk (negatief) geassocieerd met het funktioneren bij ontslag, met name wat betreft ADL-funktioneren en incontinentieproblematiek. Deze bevinding wordt bevestigd met regressieanalyse en discriminant analyse: ook hier is het Geriatrisch Complex de zwaarst wegende (korrigeerbare) variabele. Uit de verdere analyse blijkt dat het Geriatrisch Complex ook een significante rol speelt in de uiteindelijke ontslagrichting.

Hoofdstuk 7 behandelt de overleden patiënten. Uit de analyse blijkt dat leeftijd, geslacht, opnameduur en afzonderlijke ziektebeelden op zichzelf geen voorspellende waarde hebben ten aanzien van overlijden. De beperkte betekenis van diagnoses (zonder classifikatie naar ernst van de aandoening) speelt hierbij mogelijk een rol. Wel blijkt konform de verwachting dat het zelfzorgvermogen bij opname, bedlegerigheid en het hebben van een catheter bij opname significant van invloed zijn. Bij logistische regressie blijkt het niet goed mogelijk overlijden korrekt te voorspellen op grond van de gehanteerde parameters. De aanwezigheid van het Geriatrisch Complex is verrassend genoeg van ongekeerde invloed op het overlijdensrisiko. Hieruit wordt gekonkludeerd dat geriatrische problematiek eerder wordt benoemd naarmate levensbedreigende situaties minder evident aanwezig zijn.

Hoofdstuk 8 tenslotte gaat in op de betekenis die de BOP en de GIP-schaal hebben voor de geriatrische zorgverlening in het ziekenhuis. Deze relatief complexe en gedetailleerde schalen blijken verhoudingsgewijs weinig meer houvast te bieden dan de beoordeling van het ADL-funktioneren, wanneer het gaat om het bepalen van de ontslagrichting. Wel blijkt dat de de BOPschaal gevoelig is voor veranderingen in hulpbehoevendheid gerelateerd aan de aanwezigheid van cognitieve stoornissen. De GIP-schaal is in de onderzochte patiëntenpopulatie niet bruikbaar om de ontslagrichting te bepalen. Wel correleren de uitkomsten goed met de aanwezigheid van psychogeriatrische problematiek. Gekonkludeerd wordt dat de schalen een mate van nuancering geven, waaraan binnen het kader van klinisch geriatrische zorgverlening in het ziekenhuis geen konsequenties (kunnen) worden verbonden.

Op grond van de bevindingen, zoals beschreven, in de onderzochte populatie kan in het algemeen worden gekonkludeerd dat geriatrische patiënten een aparte populatie vormen binnen het geheel van oudere patiënten die in het ziekenhuis worden opgenomen. Behandeld volgens het beschreven Flankerend Geriatrisch Beleid blijken dergelijke patiënten wat het funktioneren betreft gedurende ziekenhuisopname te verbeteren. 
Het tot dusverre ontbreken van een definitie van "de geriatrische patiënt" die voldoende mogelijkheid biedt de patiëntenselektie op voorhand zodanig te doen verlopen dat geen twijfel bestaat over het feit dat geselekteerde patiënten ook daadwerkelijk vallen onder de noemer "geriatrische patiënt" vormt een belangrijk probleem bij al het onderzoek wat gedaan wordt op het gebied van de klinische geriatrie.

Daarnaast staat het de verdere uitgroei van de klinische geriatrie als volwaardig specialisme in de weg. Ook het beschreven onderzoek heeft te kampen met het ontbreken van een dergelijke gouden standaard. De verwijzer (huisarts, medewerker van de SPGD en medisch specialist) heeft bepaald wie wel en niet behandeld zal worden in het kader van het Flankerend Geriatrisch Beleid. Uit de analyses van de kenmerken van de patiëntenpopulatie blijkt dat de patiëntengroep in vele, met name medisch-diagnostische opzichten weinig homogeen is. Op zich is dit niet verwonderlijk want net zoals gesteld kan worden dat er geen specifieke ouderdomsziekten bestaan, kan ook worden beweerd dat ziekten specifiek voorkomend bij geriatrische patiënten ontbreken. De klinische geriatrie is echter een specialisme dat zich ook niet beweegt op het ordeningsniveau van ziekten en aandoeningen. Het holistische karakter van de klinische geriatrie heeft als konsequentie dat diagnoses en ziekten vertaald worden in problemen. Dergelijke problemen zijn veelal gebaseerd op de uitkomsten van ziekten en aandoeningen voor het lichamelijk, psychisch en/of sociaal welzijn. Vanzelfsprekend omvat dit meer dan uitsluitend een classificatie in bijvoorbeeld ADL-funktioneren, mobiliteitsstoornissen, urineincontinentie, overlijdensrisiko en ontslagrichting na opname in een ziekenhuis. Het is echter aannemelijk dat genoemde parameters wel een wezenlijk onderdeel hiervan uitmaken en objektiveerbare faktoren zijn. In tegenstelling tot de diversiteit die aangetroffen wordt op het vlak van een strikte ziekteclassificatie is de homogeniciteit van de onderzochte populatie en daarmee de afgrensbaarheid ten opzichte van wat genoemd wordt "gewone oudere" veel groter. Kennelijk zijn de verwijzers er in dit opzicht redelijk in geslaagd een specifieke - geriatrische - patiëntenpopulatie te onderscheiden. Omgekeerd levert analyse van de gegevens van deze populatie vervolgens de mogelijkheid om de geriatrische problematiek nader te benoemen in zodanige termen dat niet alleen retrospektief maar ook meer prospektief een patiëntenpopulatie kan worden geselekteerd die de gewenste geriatrische kenmerken heeft. Zoals is gebleken uit de onderzoeksgegevens zijn de vijf elementen van wat het Geriatrisch Complex genoemd wordt zodanig bepalend voor het beloop gedurende ziekenhuisopname dat patiënten die dergelijke kenmerken vertonen zich in velerlei opzichten significant onderscheiden. Op basis van deze konstatering kan het Geriatrisch Complex een operationeel instrument vormen zowel bij de selektie van geriatrische patiënten voor klinisch-wetenschappelijk onderzoek als voor het afbakenen van het werkterrein van de klinische geriatrische gezondheidszorg ten opzichte van andere klinische specialismen. Het cumulerend effect dat de elementen hebben op het funktio- 
neren van de patiënten biedt daarbij de mogelijkheid een classificatie te maken in termen van "mogelijke, waarschijnlijke en zekere" geriatrische patiënten. Het is overigens niet zo dat genoemde elementen op zich een verrassende bevinding zijn. In de meeste definities van geriatrische patiënten zoals tot nu toe gehanteerd zijn deze kenmerken in meer of mindere mate wel terug te vinden en er lijkt ook een duidelijke verwantschap te bestaan met wat wel genoemd wordt de "Geriatric Giants". De aangetoonde relatie van het "Geriatrisch Complex" met het funktioneren gedurende ziekenhuisopname van de onderzochte patiëntenpopulatie is te beschouwen als de vertaalslag van het medisch model (dat zich baseert op diagnoses en ziekten) naar een meer probleemgericht model, van waaruit de klinisch geriatrische zorg kan worden gerealiseerd.

Een ander aspekt van de onderzoeksbevindingen is dat de aanwezigheid van sterk uiteenlopende ziektebeelden en de hoge gemiddelde ziektelast in de onderzochte patiëntenpopulatie in kombinatie met het relatief grote aantal patiënten dat gedurende opname komt te overlijden goed passen in het beeld van kompressie van morbiditeit en rectangularisatie van de overlevingskurves. Er is sprake van toenemende desintegratie van het bestaan door het op meer dan één front falen van het adaptatiemechanisme. De therapeutische implikaties hiervan zijn duidelijk: er is geen sprake van een domino-effekt waarbij aanpak van die ene luxerende faktor leidt dat beheersing van de totale problematiek, maar veeleer van een veelheid van min of meer autonome faktoren, die een multidisciplinaire en systeemgerichte benadering vragen.

De behandeling van de onderzochte patiënten in het kader van het Flankerend Geriatrisch Beleid behoeft enige aanvullende opmerkingen. Allereerst dit is al eerder gekonstateerd - moeten de uitkomsten van het beloop wat het funktioneren gedurende opname in het ziekenhuis betreft gekoppeld worden aan de aktiviteiten die in het kader van het Flankerend Geriatrisch Beleid ondernomen zijn om het funktioneren gunstig te beïnvloeden. Wat het effekt hiervan is kan niet nagegaan worden op basis van de onderzoeksopzet. Er is geen vergelijking met een standaard-behandeling of een andere vorm van klinisch-geriatrische zorgverlening (bijvoorbeeld een GAAZ). Impliciet houdt dit ook in dat geen waardeoordeel kan worden uitgesproken over de effektiviteit van de gekozen behandeling als zodanig. Het is overigens de vraag of een dergelijk vergelijkend onderzoek tussen konsultatieve en afdelingsgebonden geriatrische patiëntenzorg zodanig kan worden opgezet dat hieraan betrouwbare gegevens ontleend kunnen worden. Het ontbreken van de mogelijkheid dergelijk onderzoek te "blinderen" en de veronderstelde aanwezigheid van vele niet voldoende objektiveerbare variabelen die een dergelijk onderzoek benvloeden en/of de generaliseerbaarheid ervan aantasten vormen belangrijke bezwaren in deze richting. Daarnaast is het de vraag welke invloed eventuele resultaten kunnen hebben op de keuzes die gemaakt worden in de klinisch geriatrische zorg. De basis voor de besluitvorming over de 
organisatie van de (klinisch-geriatrische) gezondheidszorg wordt immers zeker niet alleen gevormd door zorginhoudelijke aspekten, maar evenzeer door politieke, maatschappelijke en financieel-economische faktoren.

Voorts is er een belangrijke kanttekening te maken bij de interpretatie van de gepresenteerde onderzoeksgegevens van meer inhoudelijke aard. De dataverzameling is gedaan door personen die tevens fungeerden als behandelaar van de onderzochte patiënten. Voor variabelen zoals leeftijd en geslacht heeft dit geen konsequenties. Andere variabelen daarentegen zijn meer gevoelig voor subjektieve interpretatie en informatie bias. Dit kan geleid hebben tot een situatie waarbij de uitkomsten positiever lijken dan ze feitelijk zijn. De gevonden verschillen en de konsistentie van de onderzoeksresultaten zijn anderzijds niet zodanig dat het waarschijnlijk lijkt dat dit een rol van betekenis heeft gespeeld.

Toekomstig onderzoek, al dan niet enkelzijdig geblindeerd, in het bijzonder gericht op het effect van interventie, waarbij een strikter onderscheid gemaakt wordt tussen onderzoeker en behandelaar, kan hierover verder uitkomst bieden.

Tenslotte het fenomeen dat een deel van de patiënten die in het onderzoek zijn betrokken, waaronder in bepaalde opzichten ook de patiënten met kenmerken van het Geriatrisch Complex, zich zodanig onderscheiden van de overige patiënten dat de vraag gesteld kan worden in hoeverre dergelijke patiënten opgenomen moeten worden in een ziekenhuis danwel opgenomen moeten blijven in een ziekenhuis. Hierbij kan gedacht worden aan die patiënten bij wie de opname-indikatie overwegend sociaal van aard is geweest of patiënten die gedurende opname terecht zijn gekomen in een zogenaamde "verkeerde bed situatie" of zich zodanig ontwikkeld hebben tijclens opname dat nog slechts elementen als verzorgingsproblematiek en cognitieve stoornissen resteerden. Het onderzoek doet hierover als zodanig geen uitspraken. Gedurende de onderzoeksperiode zijn regelmatig vanuit de medische en verpleegkundige staf, vanuit de ziekenhuisorganisatie en van de kant van de ziektekostenverzekeraars kritische vragen gesteld met betrekking tot dit onderwerp. De terechtheid van ziekenhuisopname is een probleem dat onverbrekelijk verbonden lijkt met het beoefenen van de klinische geriatrie binnen de bestaande gezondheidszorgorganisatie (persoonlijke mening van de auteur). Oplossing van dit probleem vereist zowel aanpassing van de bestaande capaciteit van de gezondheidszorgvoorzieningen aan de demografische ontwikkelingen (zoals o.a. beschreven door de Scenariocommissie Vergrijzing, 1990) als een herbezinning op de doelstellingen en het zorgaanbod van algemene (en academische) ziekenhuizen in het kader van de toenemende vergrijzing en de daaraan gekoppelde toename van het aanbod van geriatrische patiënten met hun specifieke noden en behoeftes. 


\section{Literatuur}

GF Anderson, EP Steinberg. Hospital readmissions in the medicare population. New Engl J Med 1984; 311: 1349-53.

K Andrews, J Brocklehurst. Ageing of elderly britons: the direction of geriatric medicine. The Lancet 1988; i: 685-6.

WB Applegate. Hypertension in elderly patients.

Ann Int Med 1989; 110: 901-15.

AJ Bayer, MSJ Pathy. Requests for hypnotic drugs and placebo response in elderly hospital in-patients.

Postgraduate Med J 1985; 61: 317-20.

JA Bell, FE May, RB Stewart. Clinical research in the elderly: ethical and methodological considerations.

Drug Intelligence and Clinical Pharmacy 1987; 21: 1002-7.

RW Besdine. The educational utility of comprehensive functional assessment in the elderly. JAGS 1983; 31: 651-6.

RW Besdine. The maturing of geriatrics.

New Engl J Med 1989; 320: 181-2.

FJ Biesenbeek. Een persoonlijke visie op een gezondheidszorgbeleid voor de thuiswonende bejaarde.

T Geront Ger 1982; 13: 99-106.

MR Bliss. Prescribing for the elderly.

Br Med J 1981; 283: 203-6.

SGh Boghosian, AD Mooradian. Usefulness of routine preoperative chest roentgenograms in elderly patients.

JAGS 1987; 35: 142-6.

E Bruijns. Klinische geriatrie: erkend en miskend.

Medisch Contact 1985; 40: 292-3.

E Bruijns, EE van Ameyden van Duym. Contouren van een Geriatrische Afdeling in het Algemeen Ziekenhuis (GAAZ).

T Geront en Ger 1984; 15: 15-23.

LE Burley, CT Currie, RG Smith, J Williamson. Geriatrics for All?

The Lancet 1985 ; i: $674-5$. 
E Busse. Depression and antidepressants and the elderly.

J Clin Psychiatry 1983; 44: 35-9.

RN Butler. Geriatrics and internal medicine.

Ann Int Med 1979; 91: 903-8.

RDT Cape. Geriatric medicine, system or science?

The Lancet 1979; ii: 892-3.

A Cartwright, C Smith. Case finding in the elderly: do general practitioners really know enough?

Br Med J 1989; 298: 254.

A Cartwright, C Smith. Need we poison the elderly so often?

The Lancet 1988; ii: 20-22.

CBC. Kwaliteitsbevordering en de zorg voor de oude patiënt.

CBC Nieuwsbrief $1988 ; 8: 1$.

Centraal Begeleidingsorgaan voor de Intercollegiale Toetsing. Diagnostiek bij het dementiesyndroom.

Consensusbijeenkomst 4 november 1988,Utrecht.

CMM Cox, GCM Evers, R Halfens. Risico voor valpartijen bij ziekenhuispatiënten. Een onderzoek naar de bruikbaarheid van een instrument om patiënten met een verhoogd risico op vallen, vroegtijdig op te sporen.

Verpleegkunde $1987 / 88 ; 3: 162-70$.

J Crawford, MK Eye, HJ Cohen. Evaluation of monoclonal gammopathies in the 'well' elderly.

Am J Med 1987; 82: 39-45.

WB Deal. Unusual manifestations of infectious diseases in the aging.

Geriatrics 1979; 77-84.

EBM Dillmann. De functie geriatrie, een vorm van holistische gezondheidszorg. Lichtpunt in financieel-economisch moeilijke tijden?

T Geront Ger 1984; 15: 7-14.

H Diesfeldt. De BOP tien jaar.

Gerontologie 12 (3) 139-47,1981.

P Driest. Het ouderenbeleid.

De Psycholoog 1987; XXII: 494-6.

GG Fillenbaum. Screening the elderly. A brief instrumental activities of daily living measure. JAGS 1985; 33: 698-706.

IFBM Fiolet. Flankerend Geriatrisch Beleid.

The Practioner 1989; 3 maart: 157-60. 
JFBM Fiolet, $\mathrm{C}$ van Proosdij. Oud, weer aan de fles: een dubbel stigma.

NTVG 1987; 131: 977-9.

JFBM Fiolet, C van Proosdij, MJ Wendte. Flankerend Geriatrisch Beleid. Het model Maastricht.

Medisch Contact 1988; nr. 18: 566-71.

JFBM Fiolet, M Zeegers, C van Proosdij. Nachtmerries en dagdromen: nachtelijke onrust op gevorderde leeftijd.

NTVG 1987; 131: 2393-6.

JA Flendrig, JFBM Fiolet, C van Proosdij. Meer behoefte aan zorg voor ouderen. Maatschappelijke dienstplicht: de weg is er, nu de wil nog.

Medisch Contact 1988; 43: 173-5.

JA de Fockert. Klinische geriatrie. Vier jaar experimenteren in Haarlem (I).

Medisch Contact 1983; nr. 1: 17-9.

JA de Fockert. Klinische Geriatrie. Vier jaar experimenteren in Haarlem (II).

Medisch Contact 1983; nr. 2: 46-8.

JA de Fockert. Klinische Geriatrie. Vier jaar experimenteren in Haarlem (slot).

Medisch Contact 1983; nr. 3: 77-80.

JA de Fockert. Klinische geriatrie, quo vadis? Voorzichtige overwegingen bij de toekomst van een nieuw specialisme.

T Geront en Ger 1984; 15: 35-9.

JA de Fockert. De klinische geriatrische afdeling in een ziekenhuis. Officiële erkenning als experiment.

Tijdschr Ziekenhuisverpleging 1982; 35: 621-5.

JA de Fockert. Flankerend Geriatrisch Beleid (1).

Medisch Contact 1988; 43: 870.

JF Fries. Aging, natural death, and the compression of morbidity.

New Engl J Med 1980; 303: 130-5.

RA Garibaldi, BA Nurse. Infections in the elderly.

Am J Med 1986; 81 (suppl. A): 53-8.

MR Gillick, NA Serrell, LS Gillick. Adverse consequences of hospitalization in the elderly. Soc Sci Med 1982; 16: 1033-8.

GAM Golüke-Willemse, E Bruijns. De zelfredzaamheid van geriatrische patiënten tijdens en na opname op een geriatrische afdeling van een algemeen ziekenhuis.

NTVG 1987; 131: 1969-72.

JS Goodwin, JM Goodwin, PJ Garry. Association between nutritional status and cognitive functioning in a healthy elderly population.

JAMA 1983; 249: 2917-21. 
M Gordon. Weakness in the older patient: a diagnostic challenge.

Sandorama 1987; III: 36-40.

M Gosney, R Tallis. Prescription of contraindicated and interacting drugs in elderly patients admitted to hospital.

The Lancet 1984; ii: 564-7.

J Grimley Evans. Integration of geriatric with general medical services in Newcastle.

The Lancet 1983; ii: 1430-3.

WR Hazzard. Biological basis of the sex differential in longevity.

JAGS 1986; 34: 455-71.

J Hellemans, EHW van Kammen-Wijnmalen. Bijdragen over het specialisme geriatrie en de opleiding tot geriater. De ontwikkeling van de geriatrie tot een medisch specialisme.

T Geront Ger 1982; 13: 53-9.

CC Hogue. Injury in late life: Part I. Epidemiology.

JAGS 1982; 30: 183-90.

D Hoogendoorn. De hoogbejaarden ( 80 jaar en ouder) in het ziekenhuis.

NTVG $1978 ; 122: 58-62$.

D Hoogendoorn. Enkele gegevens over 64.453 fracturen van het proximale uiteinde van het femur (collum plus trochantergebied) 1967-1979.

NTVG 1982; 126: 963-8.

D Hoogendoorn. Extra sterke vergrijzing van de ziekenhuispopulatie.

NTVG 1984; 128: 2390-2.

$\mathrm{N}$ Hooyman, $\mathrm{HJ}$ Cohen. Medical problems associated with aging.

Clin Obst and Gyn 1986; 29: 353-73.

IR van Horn, AGBM Mulder, ThJG van Rens. Bejaarden en orthopedische chirurgie.

NTVG 1986; 130: 957-60.

JK Janken, BA Reynolds, K Swiech. Patient falls in the acute care setting: Identifying risk factors.

Nursing Research 1986; 35: 215-9.

N Jaspers. Geriatrische zorg in Maastricht e.o.

Een stageverslag ten behoeve van de opleiding Sociale Geneeskunde.

Interne publikatie Maastricht 1987.

JV Jones, DI Graham. Hypertension and the cerebral circulation - its relevance to the elderly. Am Heart J 1978; 96: 270-1.

P vd Kam, F Mol, M Wimmers. Beoordelingsschaal voor oudere patiënten.

Deventer: Van Loghum Slaterus, 1971. 
RA Kane, RL Kane. The feasibility of universal long-term-care benefits.

New Engl J Med 1985; 312: 1357-64.

S Katz, LG Branch, MH Bransson, JA Papsidero, JC Beck, DS Greer. Active life expectancy.

New Engl J Med 1983; 309: 1218-24.

S Katz, TD Downs, HR Cash, RC Grotz.

Progress in development of the index of ADL.

The Gerontologist 1969; 9: 48-58

S Katz, AB Ford, RW Moskowitz, BA Jackson, MW Jaffe. Studies of illness in the aged. The index of ADL: a standarized measure of biologicall and psychosocial function.

JAMA 1963; 185: 914-9.

R Katzman. Alzheimer's disease.

New Engl J Med 1986; 314: 964-73.

M Keirse. Ontslag van bejaarden uit het ziekenhuis: eindpunt of perspektief?

Metamedica 1981; 60: 403-10.

J Koch-Weser, TL Thompson, MG Moran, AS Nies. Drug therapy. Psychotropic drug use in the elderly (first part).

New Engl J Med 1983; 308: 134-8.

J Koch-Weser, DJ Greenblatt, EM Sellers, RI Shader. Drug therapy. Drug disposition in old age.

New Engl J Med 1982; 306: 1081-8.

JF Koster. Biologische basis van veroudering. De vrije radicaal-theorie.

T Geront Ger 1986; 17: 99-103.

A Kruger. The limits of normality in elderly patients.

Bailliere's Clin Haematology 1987; 1: 271-89.

H Kruit. Feiten en cijfers.

Trefpunt 1985; $1: 4$.

JN Kvale. Psychoactive drugs and the frail elderly patient.

AFP 1984; 30: 133-40.

JO Lawton, MR Baker, RA Dickson. Femoral neck fractures - two populations.

The Lancet 1983; ii: 71-2.

MP Lawton. The Philadelphia geriatric center morale scale: a revision.

J Geront 1975; 30: 85-9.

MP Lawton, EM Brody. Assessment of older people: self-maintaining and instrumental activities of daily living.

Gerontologist 1969; 9: 179. 
E Lefton, S Bonstelle, JD Frengley. Success with an inpatient geriatric unit: a controlled study of outcome and follow-up.

JAGS 1983; 31: 149-55.

F Lewis. Fracture of neck of the femur: changing incidence.

Br Med J 1981; 283: 1217-20.

MA Lewis, RL Kane, S Cretin, V Clark. The immediate and subsequent outcomes of nursing home care.

AJPH 1985; 75: 758-61.

DA Lipschitz. Syncope in the elderly.

Ann Int Med 1983; 99: 92-105.

B Lo, L Dornbrand. Sounding board. Guiding the hand that feeds. Caring for the demented elderly.

New Engl J Med 1984; 311: 402-4.

S Mader. Hearing impairment in elderly persons.

J Am Ger Soc 1984; 32: 548-53.

SH Mann. Practical management strategies for families with demented victims.

Neur Clin 1986; 4: 469-78.

LJ McVey, PM Becker, CC Saltz, JR Feussner, HJ Cohen. Effect of a geriatric consultation team on functional status of elderly hospitalized patients.

Ann Int Med 1989; 110: 79-83.

De Meier, CK Cassel. Nursing home placement and the demented patient.

Ann Int Med 1986; 104: 98-105.

J Mitchell, K Kafetz, B Rossiter. Benefits of effective hospital services for elderly people. Br Med J 1987; 295: 980-3.

JE Morley, AD Mooradian, AJ Silver, D Heber, RB Alfin-Slater. Nutrition in the elderly. Ann Int Med 1988; : 890-903.

J Munnichs. Gezondheidszorg voor ouderen: ons een echte zorg, of soms slechts een verbale suggestie?

T Geront en Ger 1989; 20: 49.

J Munnichs. De verwonderingwekkende ouderdom.

T Geront Ger 1986; 17: 1.

P Narain, LZ Rubenstein, GD Wieland, B Rosbrook, LS Strome, F Pietruszka, JE Morley. Predictors of immediate and 6-month outcomes in hospitalized elderly patients. The importance of functional status.

JAGS 1988; 36: 775-83. 
National Institutes of Health Consensus Development Conference Statement. Geriatric assessment methods for clinical decision-making.

IAGS 1988; 36: 342-7.

Nationale Ziekenhuisraad. Geriatrie als klinisch specialisme. Discussienota NZR-sectie verpleeghuizen.

Medisch Contact $1981 ; 28: 852-4$.

JF van Nieuwkerk. Contouren varı een geriatrische afdeling in een psychiatrisch ziekenhuis (GAPZ).

T Geront Ger 1984; 15: 25-33.

H Nickens. Intrinsic factors in falling among the elderly.

Arch Int Med 1985; 145: 1089-93.

MHR Nuy, J van der Plaats, M Vernooy, P Heydendael. Geriatrische patiënt, thuismilieu en voorziening.

Medisch Contact 1985; 17: 521-6.

NZI. Geriatrische afdelingen in algemene ziekenhuizen.

Nationaal Ziekenhuis Instituut, september 1986 (publicatienummer 86: 486).

JG Ouslander. Diagnostic evaluation of geriatric urinary incontinence.

Clin Ger Med 1986; 2: 715-30.

JG Ouslander, HC Sier. Drug therapy for geriatric urinary incontinence.

Clin Ger Med 1986; 2: 789-807.

J Ouslander, D Staskin, S. Orzeck, J Blaustein, S Raz. Diagnostic tests for geriatric incontinence.

World J Urol 1986; 4: 16-21.

LE van den Ouweelen-Persijn, JM de Wit-Ornee, F Gilson. Bijdragen over het specialisme geriatrie en de opleiding tot geriater. Het ontstaan en functioneren van een GAAZ.

T Geront Ger 1983; 14: 11-5.

J Passchier, EBL Bongers-Sauer, MC Dekker. Geriatrie in Arnhem. Deel 2. De plaats en de werkwijze van de GAAZ.

Nationaal Ziekenhuis Instituut, Utrecht, 1984.

PA Phillips, BJ Rolls, JGG Ledingham, MI Forsling, JJ Morton, MJ Crowe, L Wollner. Reduced thirst after water deprivation in healthy elderly men.

New Engl J Med 1984; 311: 753-9.

E Pinholt, K Kroenke, JF Hanley, MJ Kussman, PL Twyman, JL Carpenter. Functional assessment of the elderly. A comparison of standard instruments with clinical judgment.

Arch Int Med 1987; 147: 484-8.

D Post. De vergrijzing en het ziekenfonds.

Medisch Contact 1987; 42: 961-3. 
C van Proosdij. Klinische geriatrie - "un peu d'histoire".

NTVG 1977; 12: 152-6.

$C$ van Proosdij. Normale en verstoorde bewegingspatronen in relatie tot leeftijd en ziekte. NTVG 1977; 42: 1677-80.

C van Proosdij. Reactivering na circulatiestoornissen in de hersenen.

NTVG 1972; 116: 2392-403.

$C$ van Proosdij, JFBM Fiolet. Lang zullen we leven?

NTVG 1988; 132: 1177-9,

C van Proosdij, DH Sipsma. Dertig jaar vaderlandse geschiedenis. De lijdensweg van de klinische geriatrie in Nederland.

T Geront Ger 1984; 15: 3-5.

D Prudham, JG Evans. Factors associated with falls in the elderly: a community study. Age an Ageing 1981; 10: 141-6.

JAH Puxty, $\mathrm{K}$ Andrews. The role of chest radiography in the evaluation of the 'geriatric giants'.

Age and Ageing 1986; 15: 174-6.

WO Ramsey. Nutritional problems of the aged.

J Prosthetic Dentistry 1983; 49: 16-9.

N Rano. Nursing-home care in the United States.

New Engl J Med 1982; 307: 883-9.

MA Raskind, SC Risse. Antipsychotic drugs in the elderly.

J Clin Psychiatry 1986; 47 (Suppl: 17-22.)

PWM Remmerswaal. Enige essentiële vragen bij de realisering van de Geriatrische Afdeling van een Algemeen Ziekenhuis (GAAZ).

T Geront Ger 1982; 13: 60-7.

JB Reuler, TG Cooney. The Pressure Sore: Pathophysiology and Principles of Management. Ann Int Med 1981; 94: 661-6.

GS Robertson. Ethical dilemmas of brain failure in the elderly.

Br Med J 1983; 287: $1775-7$.

M Roth. Differential diagnosis of psychiatric disorders in old age.

Hospital Practice 1986; 111-38.

JW Rowe. Health care of the elderly.

New Engl J Med 1985; 312: 827-35. 
JW Rowe, E Grossman, E Bond. Academic geriatrics for the year 2000.

New Engl J Med 1987; 316: 1425-8.

LZ Rubenstein, KR Josephson, GD Wieland, PA English, JA Sayre, RL Kane. Effectiveness of a geriatric evaluation unit.

New Engl J Med 1984; 311: 1664-70.

TD Sabin. Biologic aspects of fall and mobility limitations in the elderly.

Am Ger Soc 1982; 30: 51-8.

EL Schneider. Infectious diseases in the elderly.

Ann Int Med 1983; 98: 395-400.

EL Schneider, JA Brody. Aging, natural death, and the compression of morbidity: another view.

New Engl J Med 1983; 309: 854-6.

EL Schneider, JD Reed. Life extension.

New Engl J Med 1985; 312: 1159-68.

CL Sears, ME Charlson. The effectiveness of a consultation. Compliance with initial recommendations.

Am J Med 1983; 74: 870-6.

SD Shillcutt, JL Easterday, RJ Anderson. Geriatric therapeutics: safe and effective use of antipsychotic agents.

Hosp Formul 1986; 21: 462-77.

DH Sipsma. Sociale geriatrie in theorie en praktijk.

Dissertatie, 1986.

M Siegler. Medical care for the aged. Should age be a criterion in health care?

The Hastings Center Report, October 1984; $24-7$.

DH Solomon. New Issues in Geriatric Care.

Ann Int Med 1988; 108: 718-32.

WD Spector, S Katz, JB Murphy, JP Fulton. The hierarchical relationship between activities of daily living and instrumental activities of daily living.

J Chron Dis 1987; 40: 481-9.

WW Spirduso. Physical fitness, aging, and psychomotor 'speed': a review.

J Geront 1980; 35: 850-65.

K Stewart, C Bielawska, GS Rai. Geriatric Medicine.

The Lancet 1989; ii: 506.

TM Thomas, KR Plymat, J Blannin, TW Meade. Prevalence of urinary incontinence.

Br Med J 1980; 281: 1243-5. 
ME Tinetti. Performance-oriented assessment of mobility problems in elderly patients. JAGS 1986; 34: 119-26.

ME Tinetti, TF Williams, R Mayewski. Fall risk index for elderly patients based on number of chronic disabilities.

Am J Med 1986; 80: 429-34.

J Townsend, M Piper, AO Frank, S Dyer, WRS North, TW Meade. Reduction in hospital readmission stay of elderly patients by a community based hospital discharge scheme: a randomised controlled trial.

HN Twilhaar. Hoogeveens ziekenhuis start met polikliniek voor ouderen. Rollen omgedraaid: arts zoekt patiënten op.

De Telegraaf 30-07-1988.

FRJ Verhey, J. Jolles. Over de spraakverwarring rond het begrip dementie en de ziekte van Alzheimer.

T Geront Ger 1988; 19: 89-96.

PFJ Verstraten, CWJM van Eekelen.

Handleiding voor de GIP. Van Loghum Slaterus, 1987.

PFJ Verstraten. De GIP. Veertien observatieschalen voor psychogeriatrische gedragsproblemen.

T Geront Ger 1988; 19: 147-51.

JM Vetel. Geronte: A low-cost tool to increase the quality of care of elderly persons.

Danish Med Bull 1987; 5: 93-5.

J de Vries. Cerebrovasculair accident: de rol van revalidatiecentrum en verpleeghuis.

Medisch Contact 1988; 43: 1460-3.

SH Wanzer, SJ Adelstein, RE Cranford, DD Federman, ED Hook, CG Moertel, P Safar, A Stone, HB Taussig, J van Eys. The physician's responsibility toward hopelessly ill patients. New Engl J Med 1984; 310: 955-9.

MCM van Wersch-van der Spek. Differentiaaldiagnostische problemen bij het onderzoek van de psychogeriatrische patiënt.

Medisch Contact 1986; 41: 1457-60.

GK Wilcock. Benefits of total hip replacement to older patients and the community.

Br Med J 1978; 2: 37-9.

ME Williams, NM Hadler. The illness as the focus of geriatric medicine.

New Engl J Med 1983; 308: 1357-60.

ME Williams, FC Pannill. Urinary incontinence in the elderly. Physiology, pathophysiology, diagnosis, and treatment.

Ann Int Med 1982; 97: 895-907. 
J Williamson. Geriatric medicine: whose speciality?

Ann Int Med 1979; 91: 774-7.

$\mathrm{M}$ Willmott. The effect of a vinyl floor surface and a carpeted floor surface upon walking in elderly hospital in-patients.

Age and Ageing 1986; 15: 119-20.

M Wimmers. Verpleeghuizen en hun bewoners -

Dissertatie. KU Nijmegen, 1976.

CH Winograd, LF Jarvik. Physician management of the demented patient.

JAGS 1986; 34: 295-308.

GP Wolf-Klein, T Holt, FA Silverstone, CJ Foley, M Spatz. Efficacy of routine annual studies in the care of elderly patients.

JAGS 1985; 33: 325-9.

KW Woodhouse. A geriatrician.

The Lancet 1989; i: 546.

A Young. There is no such thing as geriatric medicine, and it's there to stay.

The Lancet 1989; ii: 263-5. 


\section{Summary}

Nowadays the ageing of society and its consequences for health care are widely discussed. Most of the time little attention is paid to the difference between elderly patients and geriatric patients. Sometimes they even are considered to be identical. This is an important misunderstanding because the number of elderly patients by far exceeds the number of geriatric patients. Further more the need for care, the diagnostic and therapeutic possibilities and the general level of functional activities is not comparable.

When the specific needs of (psycho)geriatric patients are used to determine the amount of care the whole elderly population demands the outcome will be completely unreliable. This happens for instance in many publications about geriatric care. The subject is the geriatric patient but facts and figures are dealing with care for the elderly.

The fact that no good definition of a geriatric patient is available is at least in part an explanation for this confusion. Nevertheless in practical health care practitioners seem to have selection criteria for refering a patient to an ordinary health care service or an institution with a geriatric label.

In the Academic Hospital of Maastricht from 1987 a specific geriatric consultation team is functioning. This team is working with the principles of the so-called Supportive Geriatric Care. Besides conventional medical care selected patients are given additional treatment for specific geriatric needs. The whole program is focussed on functional impairments related to multiple pathology, polyfarmacy, self-care problems, psychosocial difficulties, mobility disorders, communication problems, the need for chronic care, urinary and faecal incontinence and behavioural disturbances. The team consists of an internist, a consulting psychiatrist, a specialist in rehabilitation, physical therapists, social workers and activity therapists. They work close together with all other persons involved like medical specialists and nurses. In general the geriatric treatment schedule is based upon five objectives: reactivation, resocialisation, intensive guidance of medication, functional improvement and continuity of care after discharge from the hospital.

In this thesis a report is given about the findings in the group of geriatric patients that were treated according to the principles of Supportive Geriatric Care during their stay in the hospital. The study was performed within a period of 27 months. Finally 1122 admissions were included. 
The introductory chapter is dealing with the problem of the definition of a geriatric patient and the field of clinical geriatric medicine. Also a summary is given of the objectives of the study:

- a more precise idea about the difference between normal elderly patients and geriatric patients

- a description of the medical and functional features of the geriatric patients at the moment of admission

- analysis of the development in functional capacity of the geriatric patients during their stay in hospital

- to find out what are the consequences of geriatric problems in relation to the risk of death

- to determine wether specific geriatric scales can be used for planning the care after discharge.

Chapter 1 gives a brief overview on ageing problems. After discussing the demographics and its general consequences further attention is given to health care for the elderly in general, the impact of complexity of diseases and the necessity of differentiated care of geriatric patients.

It is concluded that there are at least three types of elderly patients

- patients with simple, mostly acute intercurrent diseases

- patients with more complex, mostly chronic medical problems that can be managed in such a way that a stabilized situation can be achieved for a longer period of time

- patients in an unstable physical psychological and social condition due to multiple pathology, high level of needs and various disabilities.

Thereafter a history of international geriatric care is given with specific attention to the literature on the outcome of geriatric hospitals. With respect to the situation in the Netherlands the author gives his own ideas about the advantages and disadvantages of separate geriatric clinics. In addition some details are given about the consequences of actual health policies in the Netherlands in relation to geriatric patient care.

Chapter 2 describes more in detail the treatment philosophy and the main points of Supportive Geriatric Care. A description is given of the organisation and accruel of patients. After this the items reactivation, resocialisation, demedication, functional re-orientation and continuity of care are discussed. Reactivation deals with all the activities focussed on ADL-disabilities, mobility disorders and incontinence problems. Resocialisation means all action to optimalize the psychosocial functioning of the geriatric patients, whether or not there are any cognitive disorders. Demedication comprizes all activities to reduce the amount of medical prescriptions as much as possible. Functional re-orientation is dealing with the consequences of a shortened life 
expectancy and changes in the cure/care ratio as well as with the importance of early decissionmaking about the limits of medical care.

Finally, continuity of care is the heading for all the activities related to the transmural character of geriatric medicine.

Chapter 3 starts with a description of the background and actual accruel of the study-population. The clinical outreach of Supportive Geriatric Care is such that at least $50 \%$ of all geriatric patients in the referal area are included in the study.

The close connection between . clinical geriatric medicine and internal medicine is discussed.

Again special emphasis is given to the importance of distinction between normal elderly and geriatric patients. The aim of the study and the workinghypotheses are further discussed. This is linked to the operational effects of Supportive Geriatric Care. Thereafter a description is given of the way the research-items were registrated.

Chapter 4 gives the results of the study about the difference between normal elderly patients and geriatric patients. It is concluded that geriatric patients are more dependent on care by others and are more frequently re-admitted to the hospital. Besides physical problems they also have more frequently psychological or social problems that are responsible for their admission to the hospital. Because of their situation they are more frequently in need of consulting physicians like neurologists, psychiatrists, urologists and rehabilitation-specialists. Their average stay in hospital is twice as long compared to normal elderly patients and they die four times more often. Significant differences exist with respect to ADL-activities, mobility and incontinence problems, all in favour of the normal elderly patient. Dischargedirection is also significantly different. The amount of geriatric patients that need treatment in a chronic care hospital. a nursing home or a home for the elderly is by far higher.

These differences are proof of the existence of geriatric patients as a specific type and are the motivation for specific treatment and further research.

In chapter 5 data are presented concerning the situation of the geriatric patients at the moment of admission. Nearly all the patients that were included have problems with ADL-activity, mobility and/or urinary incontinence. On base of the list of diagnoses and problems 28 diseases are identified from which at least $5 \%$ of the patients are suffering. They are all together responsible for $60 \%$ of total morbidity. The correlation between these diseases is low. Cluster analysis according to Jaccard reveals five problems, characteristic for the study population: two-third of all patients have at least one of these problems: the so called geriatric complex. These five problems are cognitive disorders, caregiving problems, acute urinary incontinence, acute 
immobilisation and the dementiasyndrome. The presence of one or more of these problems is strongly related to funcional impairment. Attention for these problems is a central theme in geriatric care.

Chapter 6 is dealing with the change in functional impairment during stay in hospital. Significant improvement is found at all levels between admission and discharge. There is no influence of age or gender. The separate effects of the most frequent diseases are small. The geriatric complex on the contrary has a strong negative effect on the outcome of patient-care. This is confirmed by regression and discriminant analysis. The influence of the geriatric complex is also important for the need of longterm care after discharge.

Chapter 7 gives the data of the patients who died in hospital. Age, gender, length of stay in hospital and specific disease are not discriminating. Like expected from earlier findings functional impairments are of more importance. Especially the patients who have a low level of self care, who are bedridden or who have a urinary catheter have more chance to die. Nevertheless it is not possible on the basis of logistic regression anlysis to predict with enough sensitivity and specificity the outcome in individual patients. Surprisingly the occurence of parts of the geriatric complex has an inverse relation to risk of death.

It is concluded that geriatric problems are more easy denominated when lifethreatening situations are less present.

Chapter 8 describes two different geriatric assesment scales, the Beoordelingsschaal voor Oudere Patiënten (BOP) and the Gedragsobservatieschaal voor Intramurale Psychogeriatrie (GIP). These scales are relatively complex and detailed.

With the BOP-scale the influence of cognitive disorders appears stronger linked to the need for care than suggested before. As an instrument to decide for the best treatment modality after discharge the GIP scale did not prove very usefull. In general it can be concluded that both scales according to the study results provide a kind of information that cannot apropriatedly be used in the acute-care hospital. 


\section{Dankwoord}

Promoveren is als het bouwen van een huis: velen zijn betrokken bij het leggen van het fundament, de ruwbouw en de afwerking. Nu het huis er staat is het goed de architect, de aannemer, metselaars en timmerlieden en alle andere betrokkenen te bedanken.

Hooggeleerde Flendrig, beste Guus, vanaf jouw komst naar Maastricht ben jij de architect van mijn medische ontwikkeling geweest. Jouw eigen kijk op de dingen en de vasthoudendheid waarmee je jouw ideeën tot het gemeengoed van velen weet te maken zijn voor mij in vele opzichten een grote steun geweest. Zonder jou was dit proefschrift er nooit gekomen.

Hooggeleerde Philipsen, beste Hans, door jouw inzicht en wijsheid zijn vele verbeteringen tot stand gekomen. Van jou leerde ik dat veel en goed verschillende dingen zijn. Hoe laat het ook werd, de deur ging steeds weer open.

Zeergeleerde Coenegracht, beste Sjef, dankzij jou heb ik het fundament voor dit bouwwerk kunnen leggen.

Zeergeleerde van Proosdij, beste Cees, door jou heb ik de klinische geriatrie leren kennen als een zeer veelzijdig specialisme. Jouw humor, werklust en levensvreugde blijven mij bij als muizen in kattedromen.

Veel dank ook ben ik verschuldigd aan mijn medewerkers van het eerste uur Irene Speyer en Carolien Driessen. Jullie inzet voor de patiëntenzorg en het vele registratiewerk is onmisbaar geweest.

Ook degenen die na jullie gekomen zijn: Chris, Monique, Luc, Ellen en Petra (sinds kort) wil ik bedanken voor hun inzet.

John Mullink, jouw werk en voortdurende bereidheid nog even wat uit te draaien hebben zeer geholpen. Ik hoop onze samenwerking in de toekomst te kunnen continueren.

Beste Wubbo Mulder en Arie Lavrijssen, door jullie komst is mij veel werk uit handen genomen. Veel plannen kunnen nu verder verwezenlijkt worden.

Lilian Stassen en Anke Hendriks zijn degenen geweest die steeds weer gezorgd hebben dat alle aanvullingen en correcties zorgvuldig en razendsnel werden verwerkt. Regelmatig werden zij bijgestaan door Desirée, Paula en Trudy, waarvoor mijn dank. Daarbij wisten zijook nog mijn chaotisch bestaan ordelijk te agenderen.

Tiny Wouters, met jou samen heb ik de eindsprint ingezet, zonder jou had ik de streep niet gehaald.

Collegae stafleden en arts-assistenten ben ik zeer erkentelijk voor hun steun en medewerking. 
Voorst past het alle huisartsen van Maastricht e.o., evenals alle medewerkers van het "geriatrisch circuit", te bedanken voor de samenwerking in de afgelopen jaren op het gebied van de geriatrische patiëntenzorg.

Mijn ouders dank ik voor de mogelijkheden die ze mij geboden hebben en het vertrouwen dat nooit ontbrak.

Tenslotte Fransje, Frederique, Aernoud en Marguerite, volgend jaar ga ik gewoon mee op vakantie. 


\section{Curriculum vitae}

17-05-1953 geboren te Rotterdam

1971 eindexamen gymnasium bèta, Boschveldcollege te Venray

1979 artsexamen, Rijksuniversiteit Utrecht

1979 militaire dienst

1980 opleiding tot internist, Ziekenhuis St. Annadal, Maastricht (opleider J. Coenegracht)

1982

vervolg opleiding tot internist, Academisch Ziekenhuis Maastricht (opleider Prof. dr. J.A. Flendrig)

1985

inschrijving specialistenregister (Interne Geneeskunde)

1985

Rijksuniversiteit Limburg universitair docent vakgroep Interne Geneeskunde (hoofd Prof. dr J.A. Flendrig)

Academisch Ziekenhuis Maastricht staflid afdeling Interne Geneeskunde

(hoofd Prof. dr. J.A. Flendrig) 
